\title{
Efetividade dos direitos humanos, culturas jurídicas e movimentos sociais e direito do trabalho e eficácia dos direitos fundamentais no meio ambiente do trabalho
}

\author{
Alejandro González-Varas Ibáñez, \\ José Claudio Monteiro de Brito Filho, \\ Luciana Aboim Machado Gonçalves da Silva, \\ Maria Aurea Baroni Cecato, Raymundo Juliano Feitosa \\ (coords.)
}





\section{COMITÉ CIENTÍFICO}

\section{SERIE LEFIS}

\section{Coordinación}

Prof. Fernando Galindo Ayuda. Universidad de Zaragoza

Profa. María Pilar Lasala Calleja. Universidad de Zaragoza

Consejo asesor

Prof. Javier García Marco. Universidad de Zaragoza

Prof. Alejando González-Varas Ibáñez. Universidad de Zaragoza

Prof. Philip Leith. Universidad Queen's de Belfast

Prof. Emérito Abdul Paliwala. Universidad de Warwick

Prof. Aires Rover. Universidad Federal de Santa Catarina

Prof. Erich Schweighofer. Universidad de Viena

Prof. Ahti Saarenpää. Universidad de Rovaniemi 
EFETIVIDADE DOS DIREITOS HUMANOS, CULTURAS JURÍDICAS E MOVIMENTOS SOCIAIS

E DIREITO DO TRABALHO

E EFICÁCIA DOS DIREITOS FUNDAMENTAIS

NO MEIO AMBIENTE DO TRABALHO 

EFETIVIDADE DOS DIREITOS HUMANOS, CULTURAS JURÍDICAS E MOVIMENTOS SOCIAIS

E DIREITO DO TRABALHO

E EFICÁCIA DOS DIREITOS FUNDAMENTAIS

NO MEIO AMBIENTE DO TRABALHO

\author{
Alejandro González-Varas Ibáñez, \\ José Claudio Monteiro de Brito Filho, \\ Luciana Aboim Machado Gonçalves da Silva, \\ Maria Aurea Baroni Cecato, Raymundo Juliano Feitosa \\ (coords.)
}

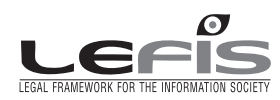


EFETIVIDADE dos direitos humanos, culturas jurídicas e movimentos sociais e Direito do trabalho e eficácia dos direitos fundamentais no meio ambiente do trabalho [Recurso electrónico] / Alejandro González-Varas Ibáñez... [et al.] (coords.). — Zaragoza : Prensas de la Universidad de Zaragoza, 2019

320 p. ; $22 \mathrm{~cm}$. - (LEFIS series ; 23)

ISBN 978-84-17633-57-8

1. Informática-Derecho-Brasil. 2. Internet en la administración pública. 3. Derechos humanosBrasil. 4. Derecho laboral-Brasil

GONZÁLEZ-VARAS IBÁÑEZ, Alejandro

34(81):004

$004.738 .5: 35$

004.738:342.7(81)

004.738:349.2(81)

Cualquier forma de reproducción, distribución, comunicación pública o transformación de esta obra solo puede ser realizada con la autorización de sus titulares, salvo excepción prevista por la ley. Diríjase a CEDRO (Centro Español de Derechos Reprográficos, www.cedro.org) si necesita fotocopiar o escanear algún fragmento de esta obra.

(C) LEFIS

(C) CONPEDI, Conselho Nacional de Pesquisa e Pós-Graduação em Direito Brasil.

(C) De la presente edición, Prensas de la Universidad de Zaragoza (Vicerrectorado de Cultura y Proyección Social)

$1 .^{a}$ edición, 2019

El Centro Universitário de João Pessoa - PB - UNIPÊ ha subvencionado parcialmente la edición de este libro.

Prensas de la Universidad de Zaragoza. Edificio de Ciencias Geológicas, c/ Pedro Cerbuna, 12. 50009 Zaragoza, España. Tel.: 976761 330. Fax: 976761063

puz@unizar.es http://puz.unizar.es

https://www.conpedi.org.br/

Esta editorial es miembro de la UNE, lo que garantiza la difusión y comercialización de sus publicaciones a nivel nacional e internacional. 


\section{SUMÁRIO}

\section{EFETIVIDADE DOS DIREITOS HUMANOS, CULTURAS JURÍDICAS E MOVIMENTOS SOCIAIS}

APRESENTAÇÃO

Raymundo Juliano Feitosa, Alejandro González-Varas Ibáñez.

A MANUTENÇÃO DA SOBERANIA ESTATAL BRASILEIRA NA GESTÃO DOS RECURSOS HÍDRICOS COMO FORMA DE AUXILIAR A SATISFAÇÃO DO DIREITO HUMANO À ÁGUA.

Andre Garcia Alves Cunha, Maria De Fátima Schumacher Wolkmer.

AS LUTAS SOCIAIS PELA EFETIVAÇÃO DO DIREITO À VERDADE E À MEMÓRIA: UMA ANÁLISE A PARTIR DAS EXPERIÊNCIAS DA ARGENTINA, CHILE E

Alex Daniel Barreto Ferreira, Gabriela Maia Rebouças.

DIREITOS HUMANOS FUNDAMENTAIS, DEMOCRACIA E POLÍTICAS ECONÔMICAS

Ricardo Antonio Lucas Camargo, Maria Cristina Cereser Pezzella.

OS DIREITOS SOCIAIS FUNDAMENTAIS NO MARCO DO ESTADO DEMOCRÁTICO DE DIREITO: A DIGNIDADE HUMANA E O "MÍNIMO EXISTENCIAL",

FUNDAMENTOS DOS DIREITOS HUMANOS FUNDAMENTAIS

Rodrigo Garcia Schwarz, Juliana De Oliveira.

TRABALHO ESCRAVO: TRAÇOS CRÍTICOS NA CONTEMPORANEIDADE. .93

Laiane Aparecida Dantas de Oliveira, Letícia da Silva Almeida.

\section{DIREITO DO TRABALHO E EFICÁCIA DOS DIREITOS FUNDAMENTAIS NO MEIO AMBIENTE DO TRABALHO}

APRESENTAÇÃO. 112

Luciana Aboim Machado Gonçalves da Silva, Maria Aurea Baroni Cecato, José Claudio Monteiro de Brito Filho.

A EFICÁCIA DOS DIREITOS FUNDAMENTAIS NO MEIO AMBIENTE DO

TRABALHO

Deilton Ribeiro Brasil, Marco Antônio de Souza.

A INCIDÊNCIA DO ISS EM REGIME DE TELETRABALHO

Manoela Bitencourt.

A TARIFAÇÃO DO DANO EXTRAPATRIMONIAL NO ÂMBITO DO DIREITO DO TRABALHO COMO FORMA DE INTERVENÇÃO DO ESTADO NA RELAÇÃO ENTRE PARTICULARES: ANÁLISE DE SUA CONSTITUCIONALIDADE. 153 Mateus Eduardo Siqueira Nunes Bertoncini, Leonardo Sanches Ferreira. 
MECANISMOS ESPECIAIS PARA A SEDIMENTAÇÃO DA TUTELA ANTIDISCRIMINATÓRIA DOS HOMOSSEXUAIS NAS RELAÇÕES TRABALHISTAS.

Adriana de Abreu Mascarenhas, Paulla Christianne da Costa, Newton.

MODERNIZAÇÃO E FLEXIBILIZAÇÃO DAS LEIS TRABALHISTAS:

TELETRABALHO E O TRABALHO INTERMITENTE

Lucas Baffi Ferreira Pinto, Jorge Heleno Costa.

NECESSIDADE DE PROTEÇÃO DA SAÚDE DOS TRABALHADORES FRENTE À PRECARIZAÇÃO DAS CONDIÇÕES DE TRABALHO

Daniele Matos de Oliveira, Sabrina Vianna Vilas Boas.

O CONTRATO INTERMITENTE E O TEMPO MORTO DE TRABALHO

Clarisse Inês de Oliveira, Patrícia Garcia dos Santos.

O DUMPING SOCIAL E A PRECARIZAÇÃO GLOBAL DAS RELAÇÕES DE TRABALHO

Augusto Eduardo Miranda Pinto, Leonardo Gama Alvitos.

O TELETRABALHO SOB A NOVA ÓTICA REGULATÓRIA - DESAFIOS E ADAPTAÇÕES DA MODALIDADE INSERIDA NO MUNDO DO TRABALHO .266 Adriana De Fatima Pilatti Ferreira Campagnoli, Silvana Souza Netto Mandalozzo.

REPENSANDO O CONCEITO DO TRABALHO ESCRAVO CONTEMPORÂNEO PARA A SUA ERRADICAÇÃO NA REALIDADE LABORAL BRASILEIRA. .285

Luciana Aboim Machado Gonçalves da Silva, Christiane Rabelo Britto.

TRABALHO DECENTE E O FUTURO DO TRABALHO 306 José Claudio Monteiro de Brito Filho. 


\section{EFETIVIDADE DOS DIREITOS HUMANOS, CULTURAS JURÍDICAS E MOVIMENTOS SOCIAIS}

\section{APRESENTAÇÃO}

El siglo XXI ha comenzado con unos avances en la comunicación como no se había producido en ninguna otra época anterior. Como todo hecho que acaece en la sociedad, también este tiene reflejos en el ámbito jurídico. Por una parte, las nuevas formas de comunicar no constituyen sino nuevos modos de ejercer la libertad de expresión. Es posible, por tanto, lesionar otras libertades públicas u otros bienes jurídicos en caso de no hacer un uso responsable de este derecho. Una de las situaciones más susceptibles en que pueden producirse conflictos de este tipo la constituye el conocimiento de la intimidad de la persona y la difusión de conocimientos sobre ella. Estamos hablando, como es fácil de adivinar, de la necesaria garantía de la protección de los datos personales. Para ello es necesaria una cuidadosa legislación que, a pesar de las dificultades, prevea las situaciones en las que las tecnologías pueden entrar en ese ámbito de intimidad preservado de las injerencias de terceros y de la indeseada difusión de las correspondientes informaciones. Se trata de una tarea tan ardua como necesaria.

Por otra parte, no puede escapársenos que las nuevas formas de comunicarnos, y también de argumentar, afectan al mismo funcionamiento de la Justicia. En efecto, la digitalización de los procesos, la posibilidad de transmitir información por medios telemáticos sin necesidad de la presencia física de las personas, o incluso avances tales como que las decisiones judiciales sean adoptadas por máquinas inteligentes, revolucionan el concepto de Administración de Justicia y del proceso. También implican un nuevo modo de argumentar, de tal modo que los oradores de los tiempos pasados, maestros de la palabra, son susceptibles de verse reemplazados por nuevos expertos del Derecho más lacónicos, más directos, o incluso -como adelantábamos- por máquinas. El tradicional humanismo, que era una de las características del Derecho y los juristas, puede que haya de ceder el paso a la técnica, el manejo del dato preciso, y al especialista cada vez menos abstracto y de miras generales y, en cambio, más centrado en lo concreto.

A ello se une que los mismos avances técnicos y tecnológicos favorecen una movilidad creciente a las personas, con lo que los movimientos sociales y las migraciones se muestran como situaciones sin retroceso. También estas situaciones desembocan frecuentemente en 
nuevos conflictos jurídicos que habitualmente afectan a los derechos fundamentales de las personas.

Las situaciones descritas requieren una reflexión sosegada y profunda para ofrecer soluciones realistas y a los problemas que plantea. Un encuentro interdisciplinar de juristas, como el que ha celebrado CONPEDI en la Facultad de Derecho de la Universidad de Zaragoza (España) durante los días 6 a 8 de septiembre de 2018, ha sido una excelente ocasión para debatir sobre estas cuestiones. En efecto, se han ofrecido propuestas de amplio alcance desde diferentes perspectivas del Derecho que han permitido una reflexión jurídica global. Su trascendencia no está llamada a agotarse en el solo espacio brasileño, sino que se proyectará necesariamente sobre otros contextos como el español y, más ampliamente, el europeo. A ello contribuirá sin duda también este libro.

Por cuanto se refiere al concreto aspecto de la efectividad de los derechos humanos, las culturas jurídicas y los movimientos sociales -temática que da título a este volumen-, se han recogido varias aportaciones de interés. Andre Garcia Alves Cunha y María de Fátima Schumacher Wolkmer presentan un capítulo titulado "A manutenção da soberanía estatal brasileira na gestão dos recursos hídricos como forma de auxiliar a satisfação do direito humano à água". Allí se conjuga con maestría el concepto del agua como bien de titularidad pública, a la vez que se propone que el acceso a este recurso constituye un auténtico derecho humano.

A continuación, Rodrigo Garcia Schwarz y Juliana de Oliveira son autores del capítulo titulado "Os direitos sociais fundamentais no marco do Estado democrático de Direito: a dignidade humana e o 'mínimo existencial', fundamentos dos direitos humanos fundamentais”. Allí se muestra un alto concepto de los derechos sociales. No se trata de un añadido de segundo orden en las Constituciones modernas o un complemento de los derechos humanos, sino que se propone un concepto de los mismos como verdaderos derechos fundamentales sobre los que necesariamente han de basarse las democracias. Se trata, por tanto, de un artículo que relaciona con agilidad los conceptos de derechos sociales, derechos humanos, y la dignidad de la persona que sustenta ambas categorías.

Por su parte, Ricardo Antonio Lucas Camargo y Maria Cristina Cereser Pezzella ofrecen una interesante aproximación al ámbito de los "Dereitos humanos fundamentais, democracia e políticas econômicas". Los autores pretenden adentrarse en las transformaciones del 
ordenamiento jurídico brasileño -a partir de las contribuciones de Rui Barbosa- en el ámbito de la sociedad de la información. Se centrarán particularmente en el posible retorno al liberalismo económico, inspirador de la Constitución de 1891.

Alex Daniel Barreto Ferreira y Gabriela Maia Rebouças presentan un estudio sobre "As lutas sociais pela efetivação do direito à verdade e à memoria: uma análise a partir das experiências da Argentina, Chile e Brasil". Desde luego que se trata de una cuestión de creciente actualidad, pues son ya varios los países que están realizando una revisión de su Historia. Si juzgar el pasado es una tarea ardua, más aún lo es cuando un parlamento o un gobierno acometen en esta tarea. Se plantean problemas jurídicos como dilucidar si esa es la tarea que corresponde a estos órganos, qué derechos deben reconocerse o qué obligaciones imponerse, o afloran nuevos debates como si se está limitando la libertad de expresión de los ciudadanos y, en particular, de los historiadores, pues pueden encontrar coartada su capacidad de investigar. En este capítulo se abordan estas cuestiones, así como las iniciativas sociales que ha habido para dilucidar los hechos históricos, centrándose fundamentalmente en Brasil, Argentina, y Chile.

Finalmente, "Trabalho escravo: traços críticos na contemporaneidade" es el título del capítulo de Letícia da Silva Almeida y de Laiane Aparecida Dantas de Oliveira. Aunque esté formalmente abolido en los países democráticos, el trabajo esclavo sigue siendo una lamentable realidad en varios de ellos. Las autoras esclarecen cómo se produce este fenómeno, sus características principales, y las omisiones de las autoridades públicas e incluso de la ciudadanía que lo favorecen. Una vez más, es la dignidad de la persona la que se encuentra en riesgo de ser vulnerada.

Se trata de un conjunto de obras presididas por el rigor científico. La bibliografía utilizada, las referencias normativas y jurisprudenciales, una metodología jurídica adecuada, y la coherencia de los razonamientos expuestos, aseguran al lector tener un conocimiento preciso de los temas tratados. Estos textos le ofrecerán nuevos motivos de reflexión en distintos ámbitos que tienen como punto de conexión el afán de garantizar la incolumidad de los derechos fundamentales y la dignidad de la persona en la era de las comunicaciones, los movimientos de pueblos y personas, y de unos avances tecnológicos que ofrecen un gran poder de transformación de la realidad a los hombres del s. XXI. Precisamente por ello, la reflexión, la responsabilidad, y una sabia prudencia como la que muestran los autores, son particularmente importantes en la actualidad. 
Coordenadores do GT:

Prof. Dr. Raymundo Juliano Feitosa - UNICAP

Prof. Dr. Alejandro González-Varas Ibáñez - UNIZAR 


\title{
A MANUTENÇÃO DA SOBERANIA ESTATAL BRASILEIRA NA GESTÃO DOS RECURSOS HÍDRICOS COMO FORMA DE AUXILIAR A SATISFAÇÃO DO DIREITO HUMANO À ÁGUA
}

\author{
Andre Garcia Alves Cunha \\ Universidade do Extremo Sul de Santa Catarina \\ Maria de Fátima Schumacher Wolkmer \\ Universidade do Extremo Sul de Santa Catarina
}

\section{Resumo}

Este artigo objetiva a (re) afirmação da soberania estatal brasileira na gestão dos recursos hídricos, sempre tendo em conta que a água é bem de uso comum do povo, ainda que na Constituição Federal àquela seja disciplinada pelo viés da dominialidade. A abordagem é relevante, pois a ninguém é dada a prerrogativa de invocar a propriedade dos bens comuns, portanto, não podem ser mercantilizados ou tratados como meros insumos a serem convertidos em bens de consumo. Deve-se erigir um pensamento destinado a fixar premissas sólidas no sentido de que a água, além de bem comum, é verdadeiro direito humano fundamental.

Palavras-chave: Soberania Estatal, Água, Dignidade Humana.

\begin{abstract}
Resumen/Résumé
This article aims at (re) affirming Brazilian state sovereignty in the management of water resources, always taking into account that water is very common use of the people, although in the Federal Constitution it is disciplined by the bias of dominance. The approach is relevant since no one is given the prerogative to invoke the ownership of common goods, therefore, they can not be commodified or treated as mere inputs to be converted into consumer goods. A thought must be erected to establish solid premises in the sense that water, as well as common good, is a true fundamental human right.
\end{abstract}

Keywords/Palabras-claves/Mots-clés: State Sovereignty, Water, Human dignity. 


\section{Introdução}

O presente artigo busca contribuir com o debate acerca da soberania do Estado brasileiro em relação a gestão dos recursos hídricos e como, em princípio, a (re) afirmação daquela implica na satisfação do direito humano à água aos habitantes do Brasil.

Para tanto, é fundamental resgatar o conceito clássico de soberania, que surge com o advento da modernidade, passando por alguns dos principais autores que trabalharam tal instituto desde o início da Idade Moderna, a exemplo de Jean Bodin, em sua obra "Os Seis Livros da República", passando, ainda, por Hobbes (O Leviatã) e, em especial, Rousseau ("Do Contrato Social").

Posteriormente, aborda-se de forma sintetizada algumas particularidades que permeiam o Estado Contemporâneo e como as mesmas, de forma direta ou indireta, dificultam o exercício da soberania estatal, não esquecendo que a mesma não deve ser levada ao extremo, visto que também serão mencionadas as contribuições que o direito internacional traz ao direito interno, em especial no que concerne a consagração de direitos humanos, sem que com isso aquela seja prejudicada.

Após mister se faz abordar a forma pela qual se dá, no Brasil, a gestão dos recursos hídricos, atualmente de domínio público, mas de certa forma compartilhada com a sociedade, na medida em que os comitês de bacias hidrográficas, instituto previsto pela lei da Política Nacional de Recursos Hídricos ${ }^{1}$, têm em seus quadros representantes da sociedade civil e são essenciais para o funcionamento do Sistema Nacional de Gerenciamento dos Recursos Hídricos.

Uma vez delineada a forma pela qual se desenvolve a gestão dos recursos hídricos no Brasil, adentrar-se-á em assunto de extrema relevância e essencial ao objeto do presente artigo, qual seja, a de compreender aqueles enquanto bens de uso comum do povo, particularidade que se por um lado não necessariamente retira do Estado o gerenciamento e/ou gestão dos recursos hídricos, por outro impede que o mesmo simplesmente possa dispor ou alienar aqueles.

Então, fixadas as premissas afeitas à soberania estatal brasileira no trato dos recursos hídricos, e sendo os mesmos bem de uso comum do povo, busca-se compreender se, efetivamente, este sistema (jurídico-político) possui maiores possibilidades de satisfazer o direito humano à água aos brasileiros, em contraponto claro ao modelo neoliberal de

\footnotetext{
${ }^{1}$ PNRH.
} 
privatização dos bens comuns, destinados à realização de uma lógica de mercado no mais das vezes excludente e predatória.

Relata-se que a pesquisa realizada teve os seguintes métodos de procedimento: $\mathrm{O}$ histórico, visto a existência de investigação de acontecimentos ou instituições do passado, para verificar sua influência na sociedade de hoje, em especial no que concerne ao conceito de Soberania Estatal. (PRODANOV; FREITAS, 2013) e bibliográfica-documental, atendo-se a conhecimentos anteriormente produzidos. (SOUZA; MÜLLER; FRACASSI; ROMEIRO, 2013).

O método utilizado para a realização deste trabalho foi o dedutivo, em que através de uma cadeia de raciocínio em ordem descendente busca-se a análise geral do trato constitucional e legal da gestão dos recursos hídricos em solo brasileiro e como a manutenção daquela pelo Estado Brasileiro, respeitada a soberania deste, tem o condão de satisfazer o direito humano à água aos habitantes do Brasil. (PRODANOV; FREITAS, 2013).

\section{O poder soberano no estado nacional}

Nas linhas abaixo busca-se investigar e delinear o conceito clássico relacionado à soberania estatal e a mutação que aquele foi experimentando no decorrer do século XX, revelando-se, atualmente, como uma espécie de poder compartilhado com inúmeros atores políticos, sociais e econômicos.

Tal análise se faz necessária como forma de desvelar ou desmistificar a concepção acerca da soberania moderna a partir do chamado Estado-Nação e seus respectivos pilares, ou seja, um poder (soberano) centralizado que exerça os poderes executivo, legislativo e jurisdicional, circunscrito por suas fronteiras, que contém um conjunto de indivíduos reconhecidos como cidadãos que o habita e vocacionado a determinadas finalidades (SILVA, 2010)

\subsection{A Soberania Estatal em Sua Concepção Clássica}

São inúmeras as definições relacionadas à soberania de um Estado-Nação. Partimos, no presente trabalho, da emanada por Jean Bodin acerca de soberania que, rompendo com a ideia do sistema medieval de organização político-social (descentralização do poder de decisão), entende aquela como centrada na figura do monarca, detentor de um poder originário (divino) e, por isso mesmo, perpétuo. (Bodin, 1997). 
A concentração de poder nas mãos do monarca (soberano) é, conforme o pensamento do autor ora trabalhado, de tamanha magnitude ao ponto deste entender que "[...] o príncipe soberano pode sem consentimento dos súditos derrogar as leis que prometeu e jurou guardar, se a justiça delas venha a cessar”. (Bodin, 1997).

Por conseguinte, o monarca não estaria submetido a leis produzidas por seres humanos (inclusive, como visto acima, as por ele próprio), mas apenas às leis divinas e da natureza, enquanto, por sua vez, o cidadão deixa de ser membro de uma cidade (civitas) para se tornar súdito do soberano. (Bodin, 1997)

Posteriormente, já sob os auspícios do pensamento iluminista, Thomas Hobbes entende o homem como eivado de paixões incontroláveis causadoras das mais diversificadas misérias morais, tais como a inveja, a iniquidade e os desejos de vingança. Para sucumbir tais características nefastas, os homens (racionalmente) renunciam suas liberdades mais primitivas para viverem nos Estados sob o manto de um "poder visível" (detentor do poder do castigo e da punição) capaz de os manter em harmonia. (Hobbes, 2017).

O chamado poder visível, mencionado por Hobbes, nada mais é do que o monarca. Neste momento, merece ser transcrita passagem da obra daquele filósofo (O Leviatã) que melhor traduz a ideia que aquele tem do monarca e a sua importância para a manutenção do Estado:

[...] Cedo e transfiro meu direito de governar-me a mim mesmo a este homem, ou a esta assembleia de homens, com a condição de transferires a ele teu direito, autorizando de maneira

semelhante todas as suas ações. Feito isto, à multidão assim unida numa só pessoa se chama Estado, em latim civitas. É esta a geração daquele grande Leviatã, ou antes (para falar em termos mais reverentes) daquele Deus Mortal, ao qual devemos, abaixo do Deus Imortal, nossa paz e defesa. Pois graças a esta autoridade que lhe é dada por cada indivíduo no Estado, é-lhe conferido o uso de tamanho poder e força que o terror assim inspirado o torna capaz de conformar as vontades de todos eles, no sentido da paz em seu próprio país, e ela ajuda mútua contra os inimigos estrangeiros. É nele que consiste a essência do testado, a qual pode ser assim definida: Uma pessoa de cujos atos uma grande multidão, mediante pactos recíprocos uns com os outros, foi instituída por cada um como autora, de modo a ela poder usar a força e os recursos de todos, da maneira que considerar conveniente, para assegurara paz e a defesa comum. Àquele que é portador dessa pessoa se chama soberano, e dele se diz que possui poder soberano. Todos os restantes são súditos. (HOBBES, 2017).

No trecho acima citado encontra-se um elemento central que orienta Hobbes em inúmeras passagens em que constrói a figura do soberano. A segurança capaz de ser proporcionada aos súditos que renunciam suas liberdades para centralizarem naquele (monarca) um poder absoluto que emana da coletividade e, por isso, capaz de manter a ordem. 
Diferentemente de Hobbes, Rousseau centra suas análises de Estado naquilo que denomina com pacto social, compreendido como um contrato dos indivíduos consigo mesmos que, mediante interesses comuns, buscam engendrar forças para obterem benefícios que não encontram no estado de natureza, este caracterizado pelo direito do mais forte. (Rousseau, 2017)

A partir de tal compreensão, Rousseau entendia como soberania a manifestação da vontade geral daqueles que renunciam seus interesses primitivos e/ou puramente individuais para viverem em sociedade (povo), em busca do bem comum (Rousseau, 2017).

Aprofunda-se tal conceito ao abstrair-se as características imanentes à soberania, quais sejam: a inalienabilidade, visto que a vontade não pode ser transmitida, mas apenas o poder afeito ao exercício da soberania; a indivisibilidade, pois a vontade geral deve ser do povo como um todo, e não de apenas parte dele; e, ainda, a limitação, que consagra os direitos dos cidadãos (fundamentados nas convenções gerais, leis) em face ao poder absoluto do soberano (Rousseau, 2017).

Importante, ainda, mencionar que a forma pela qual o pacto social ganha forma é através da lei que nada mais é do que um ato de soberania, pois revelam atos da vontade geral que demanda, todavia, o exercício da legislatura, sendo, o legislador, um homem "extraordinário no Estado" que redige boas leis a partir da sensibilidade e percepção acerca das capacidades, necessidades e a própria maturação do povo. (Rousseau, 2017).

Nesta direção, pode-se abstrair dos pensadores acima trabalhados que a soberania é juridicamente irrefutável, seja qual for o viés pelo qual a mesma possa ser analisada, manifestando-se como o exercício irresistível de um poder ilimitado capaz de impor normas de conduta, acompanhadas da coerção necessária que lhes faça valer, sempre dentro de um espaço geográfico delimitado e capaz de fazer frente às imposições externas (MORAIS, 2011).

Ocorre que essa significação vem, ao longo dos séculos, sofrendo inúmeras adaptações (voluntárias ou não) de maneira que, atualmente pode-se, como será visto no próximo item, falar em crise do Estado no que concerne às suas clássicas características. Inclusive em relação a soberania, elemento originalmente indissociável daquele.

\subsection{O Estado Contemporâneo e o Exercício (Possível) da Soberania}

Antes de entrar especificamente nos desafios e agruras que vêm paulatinamente remodelando o Estado Contemporâneo e o exercício relacionado à sua soberania, é essencial uma breve digressão afeita ao rompimento que Kelsen (já no século XX) realiza com os autores 
oitocentistas no que concerne à sua compreensão da natureza do Estado e a soberania emanada do mesmo.

Com efeito, o discurso "moderno" acerca de soberania está absolutamente atrelado à perspectiva da vontade do Poder Soberano, que se manifesta a partir das decisões do monarca e/ou de uma assembleia. No primeiro caso, através da linha sucessória e em vista do poder divino (originário) e, no segundo, pelo sufrágio.

A propósito, "abre-se um parênteses" para mencionar-se um contorno especial que se deu à soberania no curso do século XIX, em especial a partir do surgimento do sistema parlamentarista. Tal contorno manifesta-se pela representatividade, surgida no momento em que se legitima o exercício do poder soberano através do sufrágio, ou, em outras palavras “[...] a representação se apresenta como ligação natural entre os súditos e o soberano: é uma assembleia eletiva, uma assembleia de representantes, a formular a vontade soberana" (Costa, 2010).

Retomando Kelsen, o mesmo desvincula o Estado do elemento volitivo de certa forma humanizado (na figura do monarca ou da assembleia), ou, em outras palavras, retira do Estado a visão que dele se tinha como um sujeito de vontades, para ser reduzido a uma manifestação de uma determinada ordem jurídica relativamente centralizada, visto que aquele autor reconhece, por exemplo, as normas internacionais que influem na ordem jurídica estatal. (Kelsen, 2003)

O Estado, então, nada mais é do que uma ficção jurídica que, todavia, não se confunde apenas com a norma fundamental (Constituição) e suas finalidades, mas, também, com toda e qualquer tipo de criação jurídica, tais como os decretos, atos administrativos, decisões jurisdicionais, etc. (Kelsen, 2003). Portanto, "o poder do Estado não é uma força ou instância mística que esteja escondida detrás do Estado ou do seu Direito. Ele não é senão a eficácia da ordem jurídica”. (KELSEN, 2003).

Tal concepção, absolutamente positivista em verdadeiro corolário à consagração da norma jurídica como o único caminho capaz de efetivamente trazer a ordem necessária à manutenção da soberania estatal, visto que alicerçada em uma norma fundamental (Constituição) que em verdade manifestaria (em tese) a vontade popular (poder constituinte) detentora do Poder Soberano (para Rousseau), também enfrenta uma série de questionamentos e enfrentamentos que contribuem para a crise de soberania (e, também, de representatividade) atualmente verificada.

Entende-se, neste momento, necessário firmar um posicionamento que norteia o presente artigo e que voltará a ser trabalhado, ainda que de forma indireta no item posterior, 
qual seja, a de que não se pode esgotar o princípio da soberania pelo simples fato de o mesmo estar inserido no texto constitucional. Ou, de outra forma, "o princípio da soberania popular significa que a constituição é fruto da soberania popular, e não o contrário" (BERCOVIC, 2011).

Tal raciocínio deve restar assentado para que, posteriormente, esteja devidamente fundamentada a ideia que se busca delinear, qual seja, de que a soberania estatal brasileira, fruto da soberania popular, deve ser (re) afirmada no que se relaciona com a gestão dos recursos hídricos potáveis, por serem bens de uso comum do povo.

Passa-se agora a identificar as circunstâncias de fato que, de forma direta ou indireta, afetam sobremaneira o conceito de soberania em sua forma clássica (inclusive a proposta por Kelsen) e se é possível, além de desejável, o efetivo exercício do poder soberano, adaptado aos dias atuais, para que os bens essenciais a sadia qualidade de vida dos cidadãos de uma nação (e aqui trata-se especificamente dos recursos hídricos potáveis) permaneçam sob o controle da administração pública do Estado, no caso, o brasileiro.

É fundamental reconhecer, como bem retrata José Luis Bolzan de Morais, em obra já citada neste artigo, a existência de uma "dispersão nos centros de poder". Não há como permanecer no conceito de um Estado como centro único e autônomo de poder, indiferente aos controles externos (entidades supra estatais, por exemplo) e as próprias forças que emanam dentro de seu próprio território e lhe fazem a sustentação ou o contraponto. (Bolzan, 2010).

Neste aspecto, pode-se elencar inúmeras “entidades" que detém a capacidade (sócioeconômica) de relativizar o conceito de soberania estatal.

A nível internacional, citam-se não apenas as relações internacionais que colocam no mesmo plano dois ou mais Estados-Nação, manifestadas a partir da cooperação jurídica, econômica e social havida entre àqueles, como também a própria intervenção política e militar, e, ainda, as próprias comunidades supranacionais, a exemplo da Comunidade Econômica Europeia e o MERCOSUL. (BOLZAN, 2011)

No que tange a estas últimas constata-se uma profunda transformação no que concerne aos poderes dos Estados a partir da imposição de tarifas alfandegárias diferenciadas aos integrantes dos blocos, emissão de papel moeda, alianças militares, dentre outros. (BOLZAN, 2011).

Prosseguindo, é insofismável a influência de determinadas instituições privadas de imenso poderio econômico que, por este motivo, atuam junto aos parlamentares dos Estados, estando aqueles, muitas vezes, a serviço dos interesses daquelas. Tal circunstância, "fragiliza o 
modelo democrático moderno, alicerçado no pressuposto da decisão vinculante tomada por órgãos representativos do conjunto da comunidade interessada". (BOLZAN, 2011).

Ainda, menciona-se como influência direta nos centros de decisão do Estado e, portanto, com ele compartilhando o chamado poder soberano, as chamadas Organizações Não Governamentais (Anistia Internacional, Médicos Sem Fronteiras, etc.) imprescindíveis para que determinados Estados tenham acesso à ajuda internacional. (BOLZAN, 2011).

Pois bem, ainda que o conceito de Estado Soberano venha passando por inúmeras adaptações em vistas das mais variadas forças internas e/ou externas, há que se trabalhar em direção a uma adaptação que não venha a prejudicar os cidadãos dos Estados destituindo-lhes de bens de uso comum.

Neste aspecto, aceitar que o processo de conformação de um Estado é necessariamente dinâmico, tendo em conta as influências positivas e negativas, sociais, econômicas e históricas, é um primeiro passo para o reconhecimento de que o exercício da soberania não deixa de ser um processo de construção diuturna e, por isso, de luta destinada a transformar o conceito em ação prática que favoreça os indivíduos.

\section{A gestão dos recursos hídricos no Brasil e sua gestão a partir da dominialidade pública}

Inicialmente, mister se faz descrever a distinção proposta por Cid Tomanik Pompeu acerca do vocábulo água e o da expressão recurso hídrico, sendo o primeiro (gênero) um elemento natural, descomprometido com qualquer uso ou utilização, enquanto a segunda (espécie) é a água como um bem econômico, utilitário, passível de uso com tal finalidade. (Pompeu, 2011)

Após a realização desta proposta de distinção, alerta-se para a circunstância de que neste artigo adota-se o vocábulo "água" e a expressão "recursos hídricos" como sinônimos, com o escopo de facilitação relativa a compreensão do texto constitucional e do arcabouço legal, ambos afeitos à matéria.

Feitas estas breves considerações, chama-se a atenção para a particularidade de que num primeiro lançar de olhos ao texto constitucional brasileiro, tem-se que os recursos hídricos encontrados no território brasileiro são de domínio público.

Com efeito, a Constituição Federal de 1988 prevê, por exemplo, como bens da União “os lagos, rios e quaisquer correntes de água em terrenos de seu domínio, ou que banhem mais 
de um Estado, sirvam de limites com outros países, ou se estendam a território estrangeiro ou dele provenham, bem como os terrenos marginais e as praias fluviais". ${ }^{2}$

Essa construção constitucional, influenciou diretamente na forma pela qual a gestão (quantitativa e qualitativa) das águas foi concebida pelo legislador infraconstitucional, que, no ano de 1997, trouxe à lume à Lei 9.433/97, que é a Lei da PNRH.

Não se pretende, aqui, realizar uma análise aprofundada da lei ora mencionada, mas, apenas, esclarecer alguns aspectos relevantes acerca da forma pela qual a mesma contempla a gestão dos recursos hídricos em solo brasileiro para, após, fixar-se uma compreensão (retomando a interpretação constitucional acerca do tema) que (re) afirme a soberania estatal no trato deste bem público que, em verdade, se trata de uso comum do povo e quais as implicações práticas que emanam de tal entendimento.

Por conseguinte, é essencial restar claro que a Lei da PNRH explicita/descreve a água como: 1) um bem de domínio público; 2) um recurso natural limitado e; 3) dotado de valor econômico ${ }^{3}$.

Em situações de escassez, o seu uso prioritário é o consumo humano e a dessedentação de animais; sua gestão, deve ser descentralizada e contar com a participação do Poder Público, dos usuários e da comunidade e proporcionar sempre o uso múltiplo; sendo a bacia hidrográfica a unidade territorial para a implementação da política e atuação do sistema ${ }^{4}$.

Como objetivos deve-se mencionar a meta de assegurar à atual e às futuras gerações a necessária disponibilidade de água em padrões de qualidade adequados aos respectivos usos; a utilização racional e integrada dos recursos hídricos, incluindo o transporte aquaviário, com vistas ao desenvolvimento sustentável; e a preservação e defesa contra eventos hidrológicos críticos de origem natural, ou decorrentes do uso inadequado dos recursos naturais ${ }^{5}$.

E, como diretrizes da ação, para implementação da Política: a gestão sistemática dos recursos hídricos, sem dissociação dos aspectos de quantidade e qualidade; a adequação dessa gestão às diversidades físicas, bióticas, demográficas, econômicas, sociais e culturais, das diversas regiões do país 6 .

\footnotetext{
${ }^{2}$ Art. 20. São bens da União:

$[\ldots]$

III - os lagos, rios e quaisquer correntes de água em terrenos de seu domínio, ou que banhem mais de um Estado, sirvam de limites com outros países, ou se estendam a território estrangeiro ou dele provenham, bem como os terrenos marginais e as praias fluviais;

${ }^{3}$ Artigo $1^{\circ}$ da Lei 9.433/97;

${ }^{4}$ Artigo $1^{\circ}$, incisos I a VI da Lei n. 9.433/97;

${ }^{5}$ Artigo $2^{\circ}$, incisos I a III da Lei n. 9.433/97;

${ }^{6}$ Artigo $3^{\circ}$, incisos I a III da Lei n. 9.433/97;
} 
Além destas, têm, ainda, a articulação do planejamento de recursos hídricos com o dos setores usuários e com o planejamento regional, estadual e nacional; a articulação da gestão com a do uso do solo; a integração da gestão das bacias hidrográficas com a dos sistemas estuarinos e zonas costeiras e, por fim, a União deve articular-se com os Estados, tendo em vista o gerenciamento dos recursos hídricos de interesse comum ${ }^{7}$.

Os instrumentos previstos na Lei da PNRH são: Os Planos de Recursos Hídricos, o enquadramento dos corpos de água doce em classes, segundo o uso preponderante das águas, a outorga dos direitos de uso dos recursos hídricos, a cobrança pelo seu uso e o Sistema de Informações sobre Recursos Hídricos ${ }^{8}$.

Dentre todos os institutos jurídicos mencionado nas linhas anteriores, relacionados à Lei da PNRH, importam ao presente artigo, fundamentalmente, dois.

Primeiro, uma vez sendo a água um bem de domínio público, dotado de valor econômico, isso significa que o usuário deve pagar para fazer uso daquela. Paga-se, então, a prestação dos serviços de captação de água e o seu tratamento. (FREITAS, 2011).

Em Santa Catarina, por exemplo, a outorga do uso da água é realizada através da Secretaria de Estado do Desenvolvimento Econômico Sustentável, quando, em cumprimento ao artigo 12 da Lei da $\mathrm{PNRH}^{9}$, determinadas pessoas físicas ou jurídicas devem se submeter àquela.

Ocorre que, ainda que haja a cobrança pelo uso do recurso hídrico, não há transferência de propriedade. Tal particularidade, conforme o entendimento ora esposado, deve não apenas ser mantido como reafirmado com veemência, para que aquele não seja suscetível, por exemplo, de mercantilização.

Segundo, os Conselhos e os Comitês de Bacias Hidrográficas, que fazem parte do Sistema Nacional de Gerenciamento dos Recursos Hídricos, são órgãos democráticos que contemplam não apenas representantes dos governos (nacional e estaduais) como, também, da própria sociedade civil. Desta feita, os interessados direta ou indiretamente em determinados

\footnotetext{
${ }^{7}$ Artigo $3^{\circ}$, incisos IV a VI e artigo $4^{\circ}$ da Lei n. 9.433/97;

${ }^{8}$ Artigo $5^{\circ}$ da Lei n. 9.433/97

${ }^{9}$ Art. 12. Estão sujeitos a outorga pelo Poder Público os direitos dos seguintes usos de recursos hídricos:

I - derivação ou captação de parcela da água existente em um corpo de água para consumo final, inclusive abastecimento público, ou insumo de processo produtivo;

II - extração de água de aqüífero subterrâneo para consumo final ou insumo de processo produtivo;

III - lançamento em corpo de água de esgotos e demais resíduos líquidos ou gasosos, tratados ou não, com o fim de sua diluição, transporte ou disposição final;

IV - aproveitamento dos potenciais hidrelétricos;

$\mathrm{V}$ - outros usos que alterem o regime, a quantidade ou a qualidade da água existente em um corpo de água.
} 
recursos hídricos participam ativamente no planejamento e gerenciamento daqueles, seja para seu uso industrial ou para abastecimento da população (FREITAS, 2011).

Pois bem, como visto acima, o viés pelo qual se analisa o regime jurídico afeito à disciplina dos recursos hídricos se dá pela dominialidade, especificamente em conformidade com o regime jurídico dos bens públicos.

Tal regime está revelado no código civil de 2002 que reconhece serem públicos os bens de "[...]domínio nacional pertencentes às pessoas jurídicas de direito público interno; todos os outros são particulares, seja qual for a pessoa a que pertencerem"10.

Especificamente para o presente trabalho importa a definição do inciso I do artigo 99 da lei civil brasileira que dentro do gênero "bens público" categoriza a espécie "de uso comum do povo", tais como os rios e mares ${ }^{11}$. Este artigo de lei revela importância prática ímpar, visto que o meio ambiente como um todo é considerado, por força do artigo 225 da Constituição da República Federativa do Brasi1 ${ }^{12}$, como bem de uso comum do povo.

Então, não apenas legalmente, em que há a previsão expressa, mas também constitucionalmente, é legítimo compreender a água (parte integrante do meio ambiente) como bem de uso comum do povo.

A propósito, o conceito legal de meio ambiente está explicitado na Lei n. 6.938/81, em seu artigo $3^{\circ}$, inciso I, como "[...] o conjunto de condições, leis, influências e interações de ordem física, química e biológica, que permite, abriga e rege a vida em todas as suas formas".

Impensável, pelo conceito legal, compreender a água como elemento dissociado do meio ambiente, o que apenas reforça a interpretação que ora se dá ao artigo constitucional acima citado. Inclusive, tal entendimento vai ao encontro da doutrina especializada e atualíssima, que expande a compreensão da Carta Magna brasileira no sentido de atribuir ao modelo de Estado nela prevista como um Estado de Direito SocioAmbiental (SARLET, 2017).

E, por sua vez, a teoria da constituição ganha novos contornos na medida em que já se fala num direito constitucional ambiental em que se reconhece e se trabalha não apenas a dignidade da pessoa humana (apesar de ser este o objeto do presente trabalho), como também outras formas de vida não humanas. (SARLET, 2017).

Pois bem, observadas as assertivas relacionadas ao enquadramento constitucional e legal dos recurso hídricos como um bem de uso comum do povo, passa-se agora a delinear a

\footnotetext{
${ }^{10}$ Artigo 98 da Lei n. 10.406, de 10.01.2002.

${ }^{11}$ Artigo 99 da Lei n. 10.406, de 10.01.2002.

12 Art. 225. Todos têm direito ao meio ambiente ecologicamente equilibrado, bem de uso comum do povo e essencial à sadia qualidade de vida, impondo-se ao Poder Público e à coletividade o dever de defendê-lo e preserválo para as presentes e futuras gerações.
} 
consequência prática da adoção de tal entendimento, especialmente se o mesmo se expandir de maneira a influenciar as decisões dos tribunais superiores, bem como for adotado quando se falar em planejamento de políticas públicas destinadas ao gerenciamento dos recursos hídricos.

\subsection{Recursos Hídricos Como Um Bem de Uso Comum do Povo}

Para iniciar a análise proposta no presente tópico, é essencial entender que a discussão sobre o "comum" faz parte dos debates da agenda política-internacional. Neste aspecto, o comum pode ser compreendido em diferentes contextos e a partir de significados diversos.

Com efeito, a expressão "comuns" (vinda do inglês commons) é entendida como um conceito que dá sentido e direção a determinada proposta política e que se coloca a partir de quatro temas essenciais: (1) controle sobre o uso e gerenciamento de recursos e bens que compõem o patrimônio social, natural e cultural; isto é: (2) acesso a estes recursos e bens; (3) o processo de produção e reprodução social tanto de bens como de bem comum (Commonwealth); e (4) justiça distributiva na distribuição dos benefícios que emergem do nosso estoque comum. (HELFRICH, 2008)

Especificamente, importa a este artigo o comum que se revela a partir dos bens comuns aqui delineados como aqueles que conectam todas as formas de vida presentes no planeta Terra. Pode-se compreendê-los, inclusive, como elementos próprios e indissociáveis da vida, tais como o ar, o solo, a água, as sementes, o genoma humano e, até mesmo, as diversas culturas existentes. (HELFRICH, 2008).

Ainda, conforme definição adotada no presente artigo, podem ser divididos em três grandes grupos, quais sejam: "Presentes" da Natureza (bosques, vida silvestre, etc.); Criações Materiais (internet, etc.); Criações Intangíveis (arte, cultura, etc.) (BOLLIER, 2008).

Também pode-se conceber os bens comuns a partir da forma pela qual os mesmos são geridos, isto porque, aqueles trazem como “[...] implícita uma série de valores e tradições que outorgam identidade a uma comunidade e a ajudam a se autogovernar". (BOLLIER, 2008).

A partir dos entendimentos acima referidos, é lícito tratar os bens comuns como aqueles que interessam a todos e todas, e a ninguém em particular. Da mesma forma, como elementos absolutamente arraigados à determinada coletividade (localizada ou até mesmo mundial), sendo inclusive necessários à manutenção da vida humana, estão (ou deveriam estar) sujeitos a uma gestão protetiva. Esta compreensão está absolutamente divorciada da perspectiva predominante da sociedade de mercado atual, que percebe e contempla os bens comuns de forma mercadológica. 
Com efeito, os ideólogos do livre mercado entendem os bens comuns (em especial os chamados "presentes da natureza") como insumos brutos para gerar utilidades empresariais ou ativos de mercado subaproveitados, pelo que deveriam ser "transferidos" à iniciativa privada de maneira a gerarem riquezas e, portanto, progresso econômico e social. (BOILLER, 2008).

Tal concepção vai de encontro com a PNRH em vigor no Brasil e, conforme o defendido neste artigo, deve ser absolutamente rechaçada, tendo em vista que a água, como um bem de uso comum do povo, não pode ser apropriada pela iniciativa privada, quando muito podendo ser gerida pelo poder público, em conjunto com a comunidade (Conselhos e Comitês de Bacias Hidrográficas), particularidade prevista da Lei da PNRH e reafirmada com o presente artigo.

Sabe-se que a Lei da PNRH não é imune à críticas, tanto que a doutrina especializada aponta, de forma acertada, que o poder decisório nos Comitês de Bacias Hidrográficas acabam por privilegiar sobremaneira o conhecimento técnico-científico, relegando à segundo plano a atuação das comunidades e atores locais (WOLKMER; PIMMEL, 2013). Todavia, os ajustes que necessariamente devem permear a aplicação da legislação não devem servir de mote a desconstituição absoluta de um modelo que, na essência, é participativo.

Ao Estado, portanto, cabe a reafirmação de sua soberania (que nada mais é do que a vontade da população), no sentido de assumir a prerrogativa de gerir um bem que, em verdade, não é dele, mas de uso comum do povo, pertencente às presente e futuras gerações. Basta, apenas, o desenvolvimento de políticas públicas (educacionais, por exemplo), destinadas a dar voz e vez aos habitantes que integram as bacias hidrográficas.

\section{Direito humano à água a partir da reafirmação da soberania estatal brasileira na gestão dos recursos hídricos}

Pedro Arrojo em seu artigo Las Funciones Del Agua, (AGUDO, 2005) esclarece a diferenciação acerca da água potável enquanto um direito humano individual e coletivo (elemento indissociável da vida) e a água como um negócio, sujeita a comercialização:

El agua en sus funciones básicas de alimento e higiene, por un lado, y en sus funciones básicas de salud ecológica sostenible de los ecossistemas acuáticos continentales, implica valores esenciales de vida que deben ser garantizados a todas las personas y comunidades, incluyendo a las generaciones futuras. Por ello, los derechos derivados de estas funciones deben entrar de lleno e el rango de los derechos humanos, asignándoles um nivel de prioridade máximo para garantizarlos bajo la responsabilida de gobiernos e instituciones internacionales.

[...] 
Hoy por hoy, las reglas del modelo de liberalización de mercados que viene imponiendo la Organización Mundial del Comercio (OMC), son las reglas de los poderes financeiros transnacionais, impuestas por la acción de los países más poderosos. En um contexto mundial en el que no se garantizan los derechos de los más débiles y en el que la desigualdade entre los diversos actores es tan desmesurada, dificilmente puede hablarse em rigor de $<<$ libre competência $>>$. Para colmo, el hecho de que las principales potencias, como EEUU, la EU y Japón, contradiciendo los principios generales que ellos mismos defienden, mantengnan elevados níveles de subvención a sus producciones agrarias, está llevando a la agricultura de los países empobrecidos, o en desarrollo, a precisos insostenibles que arruinan sus economías ${ }^{13}$.

Pode-se afirmar, com fundamento na passagem acima citada, bem como nos demais argumentos até o momento exarados, que os bens ecológicos, como por exemplo os hídricos, demandam uma proteção específica, fortalecida e diferenciada no âmbito jurídico (inclusive pelo Direito Internacional), sob pena de apropriação indevida daqueles em benefício de poucos privilegiados (economicamente).

Neste aspecto, o direito humano fundamental à água, inserido no texto constitucional constitui, conforme Barlow, uma poderosa ferramenta prática aos cidadãos (em especial os desfavorecidos), não apenas para sua defesa junto ao Tribunal Constitucional de determinado país, como para o controle das políticas públicas e reivindicações perante tribunais internacionais. (BARLOW, 2010, p. 110).

Sabe-se que não há (ainda) consagração expressa no texto constitucional de que os recursos hídricos (água) estejam elevados ao patamar de direitos fundamentais. Todavia, pela interpretação extensiva que se pode dar ao artigo 225 da Constituição Federal de 1988 (conforme já defendido linhas acima) leva a compreensão de que tal entendimento seja adotado e pulverizado pela doutrina especializada, de maneira a se favorecer a preservação daquele bem comum e, consequentemente, auxiliar na satisfação da dignidade da pessoa humana.

\footnotetext{
${ }^{13} \mathrm{~A}$ água tem suas funções básicas relacionadas a alimentação e higiene, por um lado, e em suas funções básicas de saúde ecológica sustentável dos ecossistemas aquáticos continentais, o que implica em valores essenciais de vida que devem ser garantidos a todas as pessoas e comunidades, incluindo as gerações futuras. Por isso, os direitos derivados destas funções devem entrar diretamente na categoria dos direitos humanos, atribuindo-lhes um nível de prioridade máximo para garanti-los sob a responsabilidade de governos e instituições internacionais.

$[\ldots]$

Atualmente as regras do modelo de livre mercado, que vem impondo a Organização Mundial do Comércio (OMC), são as regras dos poderes financeiros transnacionais, impostas pela ação dos países mais poderosos. Num contexto mundial em que não se garantem os direitos dos mais desfavorecidos e aonde a desigualdade entre os diversos agentes é de tal forma desmedida, que dificilmente se pode falar em "livre concorrência". Ainda por cima, há o fato de que as principais potências, como os Estados Unidos, a União Europeia e o Japão, contradizendo os princípios gerais que eles mesmos defendem, mantenham elevados níveis de subvenção a suas produções agrárias, o que está levando a agricultura dos países empobrecidos, ou em desenvolvimento, a prática de preços insustentáveis que arruínam suas economias. (Ibiden, p. 20-21 e 27-28, tradução nossa).
} 
Neste aspecto, também das regras de direito internacional pode-se abstrair expressamente a consagração do direito humano fundamental à água. Isto porque, a Resolução 64/292 da Organização das Nações Unidas ${ }^{14}$ previu tal comando normativo.

Importante fazer aqui uma ressalva no sentido de que, no que concerne aos direitos humanos, se defende a aceitação de obrigações "determinadas" na seara internacional, sem que com isso se possa invocar qualquer tipo de mácula à soberania estatal.

Primeiro, pois, é justamente essa que faz com que se legitime a formalização de tratados internacionais e, segundo, pois a proteção destinada aos direitos humanos não pode se esgotar na esfera estatal, até mesmo porque somos, todos, habitantes desse planeta (RAMOS, 2016).

Fixadas tais premissas, entende-se que não obstante a consagração do direito humano à água ter se dado, num primeiro momento e de forma expressa, no plano internacional, sua gestão deve se dar em respeito à soberania estatal e à particularidade de que os recursos hídricos são, como já exaustivamente mencionado, bem de uso comum do povo.

Tal preocupação de (re) afirmação da soberania estatal brasileira se mostra absolutamente justificada na medida em que se veicula na imprensa (com frequência cada vez maior) discussões na seara política que podem redundar na privatização do Aquífero Guarani (maior da América Latina) ${ }^{15}$.

Inclusive, o tema já foi até objeto de dissertação de mestrado apresentada ao programa de pós graduação em direito na Universidade de Santa Maria, por Micheli Capuano Irigaray, intitulada "Privatização e Mercantilização da Água na América Latina: Desafios da Sustentabilidade e Defesa do Bem (de Uso) Comum "No" e "Para Além" do Capitalismo.

Naquele trabalho, a Autora revela incisiva preocupação, no sentido de que “[...] a água vem sendo considerada como objeto de troca, como uma mercadoria privada de circulação no mercado capitalista, em desacordo com o direito de acesso à água, expresso pela ONU como direito fundamental." (IRIGARAY, 2016).

Vladimir Passos de Freitas, em sua obra "Águas: aspectos jurídicos e ambientais” já alertava sobre a existência de grupos estrangeiros interessados em explorar serviços de tratamento de água e esgoto, havendo inclusive uma companhia privada "Azurix" que há muito considera o Brasil como um dos maiores mercados de privatização de água e esgoto. (FREITAS, 2011).

\footnotetext{
${ }^{14}$ Disponível em: http://www.un.org/es/comun/docs/?symbol=A/RES/64/292. Acesso em 04.02.2017.

${ }^{15}$ Disponível em: https:/www.correiodobrasil.com.br/multinacionais-querem-privatizar-uso-da-agua-e-temernegocia/ Acesso em 04.02.2017.
} 
Tendo em conta essa justificável preocupação, a doutrina especializada, em conjunto com os mais diversos atores sociais (desde organizações da sociedade civil, passando pela Agência Nacional de Águas e, inclusive, o Poder Judiciário) devem ter atuação incisiva na defesa da soberania nacional no trato dos recursos hídricos.

A lógica mercadológica de apropriação das riquezas naturais para conversão em bens de consumo retrata a impossibilidade (pelo absoluto antagonismo) de gestão racional dos recursos hídricos. Aquela, excludente por natureza, certamente afetará aqueles que não possuem condições econômico-financeiras para ingressar no mercado consumidor, sendo despropositado que um bem (de uso comum) se converta em produto a ser comprado e vendido no mercado aberto. Novamente, quem sofrerá as consequências são os desfavorecidos economicamente.

Desta feita, a realização do direito humano à água passa pela necessária afirmação da soberania estatal, somada ao entendimento de que os recursos hídricos sejam tratados como um bem de uso comum do povo

Tal raciocínio implica na construção (a qual vai muito além dos aspectos estritamente jurídicos) a partir das comunidades em sintonia com a sustentabilidade da natureza, compreendendo um gerenciamento ambiental comunitário, participativo e plural (IRIGARAY, 2016).

\section{Conclusão}

A partir dos estudos desenvolvidos com o presente artigo pode-se afirmar que há uma mitigação dos pilares que, na Idade Moderna, sustentaram o conceito de soberania estatal, quais sejam, a centralização do poder soberano nas esferas executiva, legislativa e judiciária, circunscrição territorial e povo. Com efeito, a globalização e suas respectivas consequências positivas e negativas resultaram em influências externas e/ou internas que fazem com que haja uma espécie de soberania compartilhada por inúmeros atores sociais, que vão desde as grandes corporação privadas, passando por entidades supra estatais de ordem mundial, até os sindicatos e associações de classe.

Todavia, essa relativização da soberania não pode, conforme o defendido neste artigo, implicar na supressão de direitos humanos lastreados em bens de uso comum do povo e, neste aspecto, propõe-se com o raciocínio explanado no transcorrer deste artigo a consideração de que os recursos hídricos integram a categoria afeita àqueles bens, pertencendo a todas e todos os indivíduos do Estado Nação (e, inclusive, ao habitantes do planeta Terra). 
Tal particularidade implica que, se por um lado deve-se (re) afirmar a soberania estatal quanto à gestão e gerenciamento dos recursos hídricos, com base na lei da política nacional destes, que prevê o compartilhamento de decisões com a sociedade civil, por outro, o regime jurídico previsto na Constituição da República Federativa do Brasil, que confere à União e aos Estados o domínio sobre às águas, não deve servir de mote a mercantilização (privatização) dos recursos hídricos, interpretação estribada na própria Carta Magna (artigo 225), quanto no Código Civil (artigo 99, inciso I).

Por fim, entende-se que a defesa que se faz da manutenção da soberania estatal, no que concerne à gestão dos recursos hídricos, favorece a satisfação do direito humano à água (ainda não expressamente previsto na Constituição Federal de 1988) na medida em que se revela (ou deve revelar) como um contraponto à lógica mercadológica de entender os bens naturais à serviço de uma sanha capitalista, que pretensamente gera riqueza econômica à partir da exploração daqueles e conversão em bens destinados à satisfação do mercado consumidor.

Ocorre que esta suposta "riqueza" alcança (historicamente) uma pequena parcela de afortunados que tem capacidade de ingressar naquele mercado, restando uma imensa "massa" de excluídos alheios aos benefícios relativos a este sistema.

\section{Referências bibliográficas}

AGUDO, Pedro Arrojo [et al.]. Lo público y lo privado en la gestión del agua: experiencias y reflexiones para el siglo XXI. Guadarrama (Madrid) - España: Del oriente y del mediterráneo, 2005.

BARLOW, Maude. Água - Pacto Azul: a crise global da água e a batalha pelo controle da água potável no mundo. São Paulo: M. Books do Brasil Editora, 2009.

BERCOVIC, Gilberto. Soberania e Constituição. 2 ed. São Paulo: Quatier Latin, 2013.

BODIN, Jean. Los seis libros de la Repúblia: selección, traducción y estúdio preliminar de Pedro Bravo Gala. $3^{\text {a }}$ ed. Madrid: Editorial Tecnos, 1997.

BRASIL. Constituição (1988). Constituição da República Federativa do Brasil. Brasília, DF: Senado Federal: Centro Gráfico, 1988. 
BRASIL. Lei n 9.433 de 1997. Brasília, DF, fev. 2017. Disponível em: http://www. planalto.gov.br/ccivil_03/Leis/L9433.htm

BRASIL. Lei n 10.406 de 2002. Brasília, DF, fev. 2017. Disponível em: http://www. planalto.gov.br/CCivil_03/leis/2002/L10406.htm

COSTA, Pietro. Soberania, Representação, Democracia: ensaios de história do pensamento jurídico. Curitiba: Juruá, 2010.

FRACASSI, Maria Angélica Thiele; MÜLLER, Deise Margô; ROMEIRO, Solange Bianco Borges; SOUZA, Dalva Inês de. Manual de Orientações Para Projetos de Pesquisa. Novo Hamburgo: FESLCVC, 2013.

FREITAS, Ernani Cesar de; PRODANOV, Cleber Cristiano. Metodologia do Trabalho Científico [recurso eletrônico]: métodos e técnicas da pesquisa e do trabalho acadêmico. -2. ed. - Novo Hamburgo: FEEVALE, 2013.

FREITAS, Vladimir Passos de. Águas: aspectos jurídicos e ambientais. $3^{\text {a }}$ ed. Curitiba: Juruá, 2011.

GARCÍA-PELAYO, Manuel. As Transformações do Estado Contemporâneo. Rio de Janeiro: Forense, 2009.

HELFRICH, Silk (org.). Genes, Bytes y Emisiones: Bines Comunes y Ciudadanía. México: Ediciones Böll. 2008.

HOBBES, Thomas. Leviatã. Disponível em: http://lelivros.love/ Acesso em 25.01.2018.

IRIGARAY, Micheli Capuano. Privatização e Mercantilização da Água na América Latina: desafios da sustentabilidade e defesa do bem (de uso) comum "no" e "para" além do capitalismo. Tese de Doutorado apresentada à Universidade Federal de Santa Maria: Rio Grande do Sul: 2016. 
MIRANDA, Jorge. Teoria do Estado e da Constituição. $4^{\text {a }}$ ed. Rio de Janeiro: Forense, 2015.

MORAIS, José Luis Bolzan. As Crises do Estado e da Constituição e a Transformação

Espaço-Temporal dos Direitos Humanos. $2^{\mathrm{a}}$ ed. Porto Alegre: Livraria do Advogado, 2011.

KELSEN, Hans. Teoria Pura do Direito. 6ª ed. São Paulo: Martins Fontes, 2003.

POMPEU, Cid Tomanik. Direito de Águas no Brasil. $2^{\mathrm{a}}$ ed. São Paulo: Revista dos Tribunais. 2011.

RAMOS, André de Carvalho. Teoria Geral dos Direitos Humanos na Ordem

Internacional. $6^{\text {a }}$ ed. São Paulo: Saraiva, 2016.

ROUSSEAU, Jean-Jacques. Do Contrato Social. Rio de Janeiro: Vozes, 2017.

SARLET, Ingo Wolfgang; FENSTERSEIFER. Direito Constitucional Ambiental: constituição, direitos fundamentais e proteção do ambiente. $5^{\text {a }}$ ed. São Paulo: Revista dos Tribunais, 2017.

SILVA, José Afonso da. Curso de Direito Constitucional Positivo. 33.ed. rev. e atual. São Paulo: Malheiros Editores, 2010.

WOLKMER, Maria de Fátima S.; PIMMEL, Nicole Freiberger. Política Nacional de Recursos Hídricos: governaça da água e cidadania ambiental. Disponível em: http://dx.doi.org/10.5007/2177-7055.2013v34n67p165 Acesso em: 20 fev.2018. 


\title{
AS LUTAS SOCIAIS PELA EFETIVAÇÃO DO DIREITO À VERDADE E À MEMÓRIA: UMA ANÁLISE A PARTIR DAS EXPERIÊNCIAS DA ARGENTINA, CHILE E BRASIL
}

\author{
Alex Daniel Barreto Ferreira \\ Universidade Tiradentes, Sergipe, Brasil. \\ Gabriela Maia Rebouças \\ Universidade Tiradentes, Sergipe, Brasil.
}

\begin{abstract}
Resumo
O presente trabalho busca destacar as experiências e tentativas de afirmação do direito à verdade e à memória após a superação dos regimes ditatoriais no âmbito dos territórios da Argentina, Chile e Brasil, comparando as suas peculiaridades e destacando as suas práticas, erros e acertos. Para atender aos objetivos propostos, realizou-se uma análise circunstanciada dos processos de afirmação desencadeados em cada um daqueles Estados, pontuando-se por fim o significado das lutas sociais como força motriz da (re)construção da paz social e da consolidação democrática.
\end{abstract}

Palavras-Chave: justiça de transição, direitos humanos, direito à verdade e à memória, democracia, movimentos sociais.

\begin{abstract}
The present article aims to presents the experiences and attempts to affirm the right to memory and truth after overcoming dictatorial regimes within the territories of Argentina, Chile and Brazil, comparing their peculiarities and highlighting their practices, errors and correctness. To attend the proposed objectives, a detailed analysis was made of the affirmation processes in each of these States, and the meaning of social movements as agents capable for the (re) construction of social peace and democratic consolidation.
\end{abstract}

Keywords: transitional justice, human rights, the right to memory and truth, democracy, social movements. 


\section{Introdução}

O estarrecedor silêncio dos Estados, que não incomumente se calam quando provocam direta ou indiretamente episódios de violação de direitos humanos, é a força motriz para que vítimas, familiares e grupos sociais de um modo geral, pressionem os agentes estatais pelo seu direito de conhecer a verdade histórica. O desconhecimento acerca do que realmente ocorreu, assim como a imposição do esquecimento, faz com que as vítimas e a sociedade em si busquem respostas e exijam do Estado esclarecimentos sobre seu passado.

O processo de lutas dos povos é fundamental para obtenção das respostas jurídicas, sociais ou políticas, e que exercem papel fundamental na condução da relação entre os grupos sociais e o passado. É, a propósito, a luta por tais respostas que dá esteio ao que se convencionou chamar, especialmente em sede de Direito Internacional Público, de "Direito à verdade e à memória".

Desse modo, este artigo objetiva enfrentar questões que dialogam com o processo de empoderamento para plena democratização nos Estados da América Latina, pautando, por via transversa, o valor das lutas destes povos e a sua relevância para superação das perturbações sociais que ainda se apresentam no cone sul.

Para tanto, serão analisadas neste trabalho, por meio de uma pesquisa exploratória, descritiva e bibliográfica e com a adoção dos métodos dedutivo e histórico, as experiências do direito à memória e verdade a partir da inspiração de uma matriz engendrada nos limites do sul.

Metodologicamente, pretende-se assim explorar a aptidão de Argentina, Chile e Brasil em relação à instituição das Comissões da Verdade e condução das suas formas de lidar com os traumas em matéria de Direitos Humanos havidos no curso das suas ditaduras civis-militares instaladas na segunda metade do século XX.

Ao aproximar os exemplos latino-americanos de transição no presente artigo, adota-se o entendimento de que pavimentar um caminho democrático e emancipador, pautado na experiência regional de consagração do direito à memória e à verdade, sob a égide dos seus próprios padrões culturais, sugere uma possibilidade de identificação e experimentação colaborativa.

$\mathrm{Na}$ esteira dos exemplos latino-americanos propostos pelo presente artigo, explora-se primordialmente a experiência dos Estados nas lutas pela garantia dos seus direitos à memória e verdade e seus avanços nas suas transições. Para tal, elegemos os casos paradigmáticos, tendo utilizado como parâmetro para escolha: i) a instituição das comissões da verdade nos territórios 
de tais Estados; ii) a precedência de lutas populares pela criação das comissões; iii) o reflexo perante os órgãos dos sistemas de justiça conhecidos e perante as estruturas do Estado.

É desta forma que se buscará evidenciar a amplitude destas experiências, apontando as eventuais possibilidades de aperfeiçoamento das democracias e dos caminhos de afirmação dos direitos humanos a partir da consolidação do direito à memória e à verdade.

\section{O caso argentino: As lutas da Plaza de Mayo pela memória e pela verdade e a rápida instituição da Comissão Nacional de Investigação sobre o desaparecimento de pessoas}

A Argentina, usualmente referida como pioneira na adoção de instrumentos transicionais, viu o seu governo ditatorial perder a legitimidade gradativamente. Malgrado não se possa falar em queda revolucionária da ditadura argentina, já que as eleições diretas foram convocadas pelo próprio governo militar que já admitia ser impossível continuar no poder, sobretudo em razão da crise econômica que assolava o país, não se nega que o fim do regime tenha sido precedido por uma grande insatisfação social, manifestada através de intensas lutas que congregavam a sociedade em seus mais diversos segmentos ${ }^{1}$ e que desaguavam na Plaza de Mayo (COGGIOLA, 2001, p.80).

O modelo argentino de transição é representado por um processo redemocratizante retratado por uma desvinculação moderada ${ }^{2}$ que permitiu ao governo eleito, já nos primeiros atos constitucionais, criar a Comissão Nacional de Investigação sobre o Desaparecimento de Pessoas (CONADEP), encarregada de investigar as violações de direitos humanos ocorridas nos anos de chumbo ${ }^{3}$.

Naquelas condições, a CONADEP passou a atuar com o objetivo de esclarecer as questões primordialmente relacionadas ao desaparecimento de pessoas no período da ditadura militar argentina ${ }^{4}$. Por determinação legal, o material adquirido pela Comissão em suas

\footnotetext{
${ }^{1}$ Cabe destacar que a resistência operária marcou a experiência autoritária argentina. Coggiola (2001, p. 77) aponta inclusive que a crise econômica que culminou na deslegitimação do regime autoritário foi impulsionada, em parte, por greves longas e duras dos ferroviários e operários da carne, por exemplo.

${ }^{2}$ Diz-se desvinculação moderada porque, o país, como aliás, sempre acontece em períodos de transição, vivia um clima de instabilidade e, o aparato estatal ainda era povoado por membros da repressão que, em alguma medida estavam envolvidos nas apurações e trabalhos da CONADEP.

${ }^{3}$ Antes de deixar o poder, os militares argentinos promulgaram uma lei de autoanistia. Tamanha insatisfação popular permitiu que o congresso nacional anulasse a lei de anistia, anulação cuja validez constitucional a Suprema Corte Argentina mais tarde referendaria.

${ }^{4}$ Do texto encontrado no Decreto Lei 187/1983, extraímos do Art. $1^{\circ}$ que o estado argentino, com a promulgação do instrumento legislativo se propunha a: "Constituir una Comision Nacional que tendra por objeto esclarecer los hechos relacionados con la desaparicion de personas ocurridos en el pais".
} 
investigações e procedimentos seria remetido aos órgãos do Poder Judiciário, esse encarregado de apontar eventuais responsabilidades.

No esteio das razões que conduziram a escolha deste trabalho em falar do Estado argentino como exemplo de aproximação, é relevante que sejam ressaltadas as ações e movimentos que impuseram a criação da CONADEP.

Mariasch (2009) propôs a criação de uma cartografia dos movimentos de luta pela memória e verdade que se desencadearam na Argentina mesmo no curso do regime autoritário, e elencou a existência de pelo menos quatro movimentos sociais que lutavam diretamente pela causa: Madres e Abuelas de Plaza de Mayo e Familiares de Detenidos e Desaparecidos por Razones Políticas; Movimento Ecumênico por los Derechos Humanos (MEDH) e o Servicio Paz y Justicia (SERPAJ), este último, um organismo internacional, que tem ligação com aquilo que se convencionou chamar de "esquerda cristã" e que se enraizou por toda América Latina naquele contexto, pautando uma proposta de formação e educação em Direitos Humanos (FRUHLING, 1989, p. 366).

Não obstante, a CONADEP, embora formalmente representasse uma conquista aos movimentos de luta pela memória e pela verdade, seguiu em parte, a dinâmica dos pactos democratizantes típicos dos processos de redemocratização na região. Assim narra Mariasch (2009):

\begin{abstract}
A composição burguesa dos notáveis da CONADEP e a preeminência de adeptos da teoria dos "dois demônios", dentre outros, a jornalista Magdalena Ruiz Guinazu, Graciela Fernandez Mejide militante dos direitos humanos e o escritor Ernesto Sábato, membros da APDH, foram fatores de fervorosas discussões, especialmente nos movimentos de afetados diretos. (...) Esses foram também os motivos da oposição das Madres aglutinadas em torno de Hebe Bonafini, que acusaram ainda a permanência em serviço de uns 400 juizes da ditadura e a Ley de Presunción de Fallecimiento, uma "solução final", que segundo as Madres tinha sido preparada por Alfonsín para Videla em agosto de 1979. (MARIASCH, 2009, p.166).
\end{abstract}

Ao cabo de nove meses de trabalho, a CONADEP apresentou um levantamento das suas atividades, reunindo depoimentos e outros dados. Aquele relatório ganhou o nome de: "Nunca Más: Informe de la Comisión Nacional sobre la Desaparición de Personas" e promoveu diversas recomendações para diferentes ramos do governo argentino com a finalidade de prevenir, reparar e evitar a repetição de violações de Direitos Humanos.

Possivelmente, por razões que podem ser explicadas com base na visível ligação da CONADEP com figuras do prior regime, foram precipitadas pela aprovação das leis do "Ponto

\footnotetext{
${ }^{5}$ Em linhas gerais, a argumentação que varia em torno da chamada "teoria dos dois demônios" pretende se justificar na medida em que a violência da parte dos opressores teria sido praticada apenas em razão da violência igualmente praticada pelos atores sociais que se opunham ao regime.
} 
Final" (Lei n. 23.492) e "Obediência Devida" (Lei n. 23.521), a primeira em dezembro de 1986 e a segunda em junho de 1987. As leis autoanistiantes foram aprovadas após o episódio que ficou conhecido como "Nuremberg Argentino", em 22 de abril de 1985.

A Lei do Ponto Final estabelecia prazo para que novas ações penais fossem ajuizadas em desfavor dos perpetradores, no caso da Lei da Obediência Devida, passava-se a considerar isentos de responsabilização aqueles que alegavam ter cometido crimes por ordens superiores. Mais tarde, o sucessor de Alfonsin, o ex-presidente argentino Carlos Menem, ainda concederia o perdão presidencial ${ }^{7}$ a pelo menos quatro líderes das juntas que já haviam sido julgados e condenados.

Todavia, graças a perene mobilização dos movimentos sociais argentinos que, segundo Médici (2007), passaram a adotar estratégias de escândalo, de escracho ${ }^{8}$, impondo que os poderes do Estado pudessem apresentar respostas às suas demandas, os perdões presidenciais acabaram sendo revogados perante os tribunais argentinos.

Diante desse cenário, o Estado passou ainda a adotar uma política de reparação econômica e de reconhecimento do direito à memória e à verdade que, entre outras conquistas, passou a identificar crianças sequestradas pelo regime ou nascidas em cativeiro. O Poder Judiciário, por sua vez, reconheceu a inconstitucionalidade das leis autoanistiantes, retomando a rotina de julgamentos em sede criminal ${ }^{9}$.

Segundo Pita (2004, p.435, 458), trata-se de um processo que, apesar de resultar de decisões governamentais (Estado liberal na sua acepção), vincula-se muito diretamente com as estratégias de intervenção dos atores sociais, que propuseram a construção de condições para que as suas demandas fossem reconhecidas como uma questão de relevância pública na construção de uma identidade coletiva.

\footnotetext{
${ }^{6}$ O episódio ficou conhecido como "Nuremberg Argentino" em alusão ao julgamento do Tribunal Militar que, no contexto do pós-Segunda guerra, decretou 12 condenações à morte, 3 prisões perpétuas, 2 condenações a 20 anos de prisão, uma a 15 e outra a 10 anos, todas em desfavor de dirigentes nazistas.

${ }^{7}$ Temos aqui uma evidente manifestação de engodo na política do perdão argentino. No entender de Ricoeur (2008), o perdão presidencial é algo impossível, sendo no máximo uma teatralização do perdão, por ser uma ação de Estado e não das vítimas (individualmente), agora em condições de punir e consequentemente, perdoar.

${ }^{8}$ Segundo o próprio Médici (2007), o escracho é uma forma de condenação social que tem por objetivo "pôr em evidência", "tornar visível" o que está oculto e encarna uma forma de resistência ativa que instala, no centro da cena pública, o debate sobre o lugar da lei, o sentido da justiça e o efeito degradante e perverso das diversas formas de impunidade.

${ }^{9} \mathrm{O}$ processamento de agentes do regime tem se dado de maneira contínua. Enquanto o presente trabalho era redigido, mais precisamente em 30 de novembro de 2017, o Portal de Notícias "G1" publicava matéria dando conta da condenação de 48 ex-militares por crimes praticados durante o período autoritário: https:/g1.globo.com/mundo/noticia/argentina-condena-48-ex-militares-por-voos-da-morte-e-outros-crimes-daditadura.ghtml
} 
Quadro 1. Análise descritiva da experiência argentina

\begin{tabular}{|c|c|c|}
\hline Comissões da Verdade & Precedência de Lutas Sociais & $\begin{array}{l}\text { Reflexos no sistema de Justiça e } \\
\text { estruturas do Estado. }\end{array}$ \\
\hline $\begin{array}{l}\text { Comissão Nacional sobre o } \\
\text { Desaparecimento de Pessoas - } \\
\text { CONADEP: } \\
\text { Mandato para investigar os } \\
\text { eventos ocorridos entre } 1976 \text { e } \\
1983 \text {. }\end{array}$ & $\begin{array}{l}\text { Mobilização de atores sociais, } \\
\text { com destaque para Madres e } \\
\text { Abuelas de Plaza de Mayo e } \\
\text { Familiares de Detenidos e } \\
\text { Desaparecidos por Razones } \\
\text { Políticas }\end{array}$ & $\begin{array}{l}\text { Apesar do expressivo número de } \\
\text { condenações criminais, registra- } \\
\text { se a recorrente tentativa de barrar } \\
\text { as investigações através do } \\
\text { legislativo. } \\
\text { O Judiciário, por sua vez, alterna } \\
\text { entre condenações, absolvições e } \\
\text { abrandamento de penas, como no } \\
\text { caso recente da aplicação da } \\
\text { chamada Lei do } 2 \times 1 \text {. }\end{array}$ \\
\hline
\end{tabular}

Fonte: Elaboração própria, 2018.

De fato, é possível observar que o modelo argentino de luta pela memória e verdade é propositivo no sentido de incluir o coletivo de nacionais na sua dinâmica a partir do reconhecimento da pauta como matéria de relevância geral. Contudo, é necessário que se registre, que até os dias atuais, o Estado argentino de forma não pouco usual, pauta demandas de revisão das punições como quando o congresso argentino buscou aprovar lei que prevê a redução das condenações de responsáveis da ditadura militar ${ }^{10}$.

Por outro lado, mesmo reconhecendo a culpabilidade de alguns perpetradores em determinados processos e afastando a aplicação das leis autoanistiantes, o Poder Judiciário argentino oscila entre condenações, absolvições ${ }^{11}$ e diminuições de pena. Assim, não têm sido ocasionais as idas dos movimentos sociais às ruas, sempre hasteando a bandeira que prega o fim da impunidade ${ }^{12}$.

\section{O caso chileno: As lutas populares e a busca pela consagração do direito à verdade em dois tempos}

\footnotetext{
${ }^{10}$ Nesse sentido, confira notícia publicada nos portais de notícia, e que datam de maio de 2017: https://www.dn.pt/mundo/interior/milhares-de-argentinos-protestam-contra-reducao-de-penas-de-ditadores8466241.html

${ }^{11}$ Como no caso que envolvia o julgamento dos militares supostamente envolvidos na “Operação Condor". Cf em: http://www1.folha.uol.com.br/mundo/2017/02/1862278-absolvicao-de-militares-por-operacao-condordecepciona-parentes.shtml

${ }^{12}$ Recentemente, no ano de 2017, a Suprema Corte Argentina decidiu aplicar em favor dos presos a chamada Lei do 2 x 1. A legislação esteve em vigor por curto período no país, entre 1994 e 2001, e tinha como objetivo acelerar os julgamentos e impedir longos períodos de prisão preventiva. Pelo texto, cada ano em que alguém ficasse detido esperando julgamento valeria por dois após a condenação. Na prática, reduzia a pena pela metade.
} 
Assim como na Argentina e na grande maioria dos Estados latino-americanos, o regime autoritário chileno apenas deixou o poder após a realização de um arranjo institucional.

Após plebiscito, cuja previsão era contida na Constituição promulgada pelo regime autoritário, o povo chileno optou, no ano de 1988, pela realização de eleições diretas para os poderes Executivo e Legislativo. Apesar da suposta derrota, o então ditador Augusto Pinochet, por força do que diria a Constituição chilena por ele referendada, manteve-se como senador vitalício, chefiando as forças armadas e integrando o conselho nacional de segurança, que na estrutura do então Estado Chileno se reputava mais relevante do que a Presidência da República ${ }^{13}$.

Após a eleição de Patricio Aylwin, opositor de Augusto Pinochet, a chamada Comissão Nacional da Verdade e Reconciliação - CVR foi criada no Chile. Orellana e Hutchison (1991, p. 20) registraram que ainda no curso do regime autoritário chileno pelo menos dois grandes movimentos haviam se organizado com o propósito de lutar pelo direito de conhecer a verdade histórica: Chile Defiende la Vida e Comité por la Vida, la Justicia y la Verdad. Segundo os autores:

Este esforço de coordenação teve sua máxima expressão na Jornada pela vida, realizada em Agosto de 1984. Durante essa jornada foi o "Plenário" e as demais instituições de Direitos Humanos. Nesta jornada participaram dezenas de milhares de pessoas. (ORELLANA e HUTSCHISON, 1991, p.50) ${ }^{14}$.

O "Plenário" a que Orellana e Hutschison fazem referência foi fruto da união de uma série de movimentos de defesa dos Direitos Humanos no Chile, liderado pelo Servicio de Paz y Justicia - SERPAJ, mesmo grupo que atuou no modelo argentino.

Assim, a instituição da CVR no governo Aylwin não se deu por mera política de governo, mas decorreu de intensa pressão dos movimentos sociais. A CVR tinha objetivo de contribuir para o esclarecimento da verdade sobre as graves violações de Direitos Humanos ocorridas durante o período do autoritarismo e trouxe as sugestões de reparação às vítimas, consistentes em medidas sociais concretas, como estabelecimento de pensão, auxílio especial à saúde, prestação à educação, habitação, além de ter recomendado a isenção de prestação de serviço militar obrigatório para os filhos das vítimas.

\footnotetext{
${ }^{13}$ Linz e Stepan (1999, p. 243) recordam que Augusto Pinochet apenas abriu mão do poder porque a própria oposição já havia se reunido, em consenso, com o propósito de aceitar a mantença da chamada "Constituição do General". Para os autores, o modelo chileno representa a mais "desleal" transferência de poder nos casos de transição da América Latina. Cf. em: https://tn.com.ar/sociedad/quien-luis-muina-el-torturador-civil-beneficiadocon-el-2-x-1 790436

${ }^{14}$ Tradução livre do original: "Este esfuerzo de coordinacion tuvo su maxima expression en Ia Jornada por la vida, realizada en Agosto de 1984. En esa jornada, uno de los principales organizadores y movilizadores fue el Plenario y las demas instituciones de derechos humanos. En esta Jornada participaron varias decenas de miles de personas.".
} 
A Comissão chilena, assim como a CONADEP, apresentou recomendações legislativas, naturais medidas de não repetição. Exemplos destas eram: a) sugestão da adequação da legislação nacional ao direito internacional sobre os Direitos Humanos e a ratificação de tratados internacionais de Direitos Humanos, b) reformas no sistema judicial e as forças armadas (RAMOS, 2012).

Sob o ponto de vista da interação dos mecanismos de verdade com os órgãos de justiça formal, as políticas do governo Aylwin caminharam no sentido de que, após divulgação do Relatório da CVR, o Informe Rettig, os casos seriam submetidos a apreciação do Poder Judiciário, apenas mediante provocação das vítimas. As buscas pelos tribunais, entretanto, não resultavam positivamente, na medida em que encontravam dois significativos óbices: i) a Lei de Anistia promulgada em 1978, o Decreto-Lei n. 2191/78, e ii) o aparelhamento dos órgãos de Estado com o legado autoritário ${ }^{15}$.

Em face desses óbices, apesar do relevante trabalho desempenhado, os resultados do Informe Rettig, como ficou conhecido o documento produzido pela CVR, tornou-se parcialmente ineficaz, apresentando números que inclusive não traduziam a realidade do número de mortos e desaparecidos no Chile. O movimento só retomaria força treze anos após a criação da Comissão Valech.

A nova Comissão, assim como a primeira, surgiu a partir dos tensionamentos provocados pelos movimentos sociais chilenos, insatisfeitos com a solução parcial ofertada pelo Informe Rettig. Assim como no exemplo Argentino, os movimentos sociais chilenos, além da organização das passeatas e manifestações nas ruas de Santiago, passaram a adotar a rotina do escracho através do que chamaram de comisiones FUNA. A proposta seria, portanto, denunciar publicamente aqueles que cooperaram com o Regime autoritário, expondo-os perante a sociedade.

Por outra via, em busca da feição da chamada "Justiça Material", os movimentos sociais passaram a disparar demandas perante os órgãos de Justiça Transnacional, a exemplo do caso Almonacid Arellano vs. Chile, submetido em 1998 ao Sistema Interamericano de Proteção aos Direitos Humanos, e que pretendia questionar a validade da lei autoanistiante ${ }^{16}$.

\footnotetext{
15 Antes de transmitir o poder a Alwyin, o regime autoritário deu conta de assinar leis constitucionais que favoreciam a intangibilidade dos perpetradores, além de garantir a manutenção do poder pela via do Conselho de Segurança ao próprio Augusto Pinochet. Linz e Stepan (1999, p. 247) indicam que doze dias antes de deixar o poder, Pinochet havia nomeado, por exemplo, no Ministério do Interior, 556 (quinhentos e cinquenta e seis) novos servidores públicos, conferindo-lhes estabilidade.

${ }^{16}$ Em decisão paradigmática, a Corte IDH considerou que o assassinato do senhor Almonacid Arellano formou parte de uma política de Estado de repressão a setores da sociedade civil e representa apenas um exemplo do grande conjunto de condutas ilícitas similares que se produziram durante essa época.
} 
Nesse contexto, a segunda comissão da verdade, conhecida como "Comissão Valech", ampliou significativamente os trabalhos, e praticamente dobrou o número de vítimas do regime autoritário, antes fixado pelo Informe Rettig em 27.200 (vinte e sete mil e duzentas) vítimas, e depois atualizado pelo Informe Valech para 40.280 (quarenta mil duzentos e oitenta) pessoas, entre desaparecidos, mortos e torturados ${ }^{17}$.

Como reflexo da mobilização da Corte Interamericana, a Suprema Corte chilena afastou a lei autoanistiante quando da análise de processo criminal que se referia à execução forçada praticada por agentes do regime e que vitimou dois militantes dos movimentos insurgentes ${ }^{18}$.

O Chile, por outra via, registrou a existência de outros processos de reparação, como o pagamento de pensões ou concessão de aposentadorias de dezenas de milhares de pessoas que foram exoneradas de seus trabalhos na administração pública ou em empresas estatais por razões políticas, além das alterações de nomes de logradouros e, por último, uma reforma nas instituições de processo penal do Estado chileno.

\section{Quadro 2. Análise descritiva da experiência chilena}

\begin{tabular}{|c|c|c|}
\hline Comissões da Verdade & $\begin{array}{l}\text { Precedência de Lutas } \\
\text { Sociais }\end{array}$ & $\begin{array}{l}\text { Reflexos no sistema de Justiça } \\
\text { e estruturas do Estado. }\end{array}$ \\
\hline $\begin{array}{l}\text { Comissão Nacional da } \\
\text { Verdade e Reconciliação - } \\
\text { Comissão Rettig } \\
\text { (Mandato para investigar } \\
\text { eventos ocorridos entre } \\
\text { 11.09.1973 e 11.03.1990) } \\
\text { Comissão Nacional sobre } \\
\text { Prisão Política e Tortura - } \\
\text { Comissão Valech. } \\
\text { (Comissão com fim } \\
\text { específico constituída para } \\
\text { apurar eventos de 11.09.1973 } \\
\text { e 11.03.1990). }\end{array}$ & $\begin{array}{l}\text { Mobilização de atores sociais, } \\
\text { com destaque para Chile } \\
\text { Defiende la Vida e Comité } \\
\text { por la Vida, la Justicia y la } \\
\text { Verdad, além da } \\
\text { concentração de outros } \\
\text { movimentos junto a } \\
\text { "Plenária". } \\
\text { Permanente tensionamento } \\
\text { promovido pelas Comissões } \\
\text { FUNA e pelo Agrupamento } \\
\text { de Familiares de Detidos } \\
\text { Desaparecidos do Chile. }\end{array}$ & $\begin{array}{l}\text { Diversas condenações } \\
\text { criminais, superação da lei } \\
\text { autoanistiante, reforma da } \\
\text { estrutura de Justiça Criminal. } \\
\text { Apesar do expressivo número de } \\
\text { condenações criminais, registra- } \\
\text { se a recorrente tentativa de } \\
\text { barrar as investigações através } \\
\text { do legislativo, e uma retomada } \\
\text { de escalada do } \\
\text { conservadorismo. } \\
\text { também interpretação recente da } \\
\text { Suprema Corte que aplicou a } \\
\text { regra de prescrição dos crimes } \\
\text { comuns em favor de alguns } \\
\text { agentes do regime. } \\
\text { Por outro lado, a prisão para a } \\
\text { qual a maioria dos agentes do } \\
\text { regime Pinochet foram } \\
\text { encaminhados é cercada de }\end{array}$ \\
\hline
\end{tabular}

\footnotetext{
${ }^{17}$ A íntegra do Informe é acessível em: http://www.derechoshumanos.net/paises/America/derechos-humanosChile/informes-comisiones/comision-nacional-prision-politica-y-tortura.htm

18 Tratamos aqui do caso "Miguel Angel Sandoval". Rol 517-2004, Corte Suprema Chilena, julgado em 17/11/2004, cuja integralidade pode ser acessada em: http://dx.doi.org/10.4067/S0718-00122004000200011.
} 
Apesar dos processos reparatórios, algumas insuficiências ainda são notadas no modelo transicional chileno. Embora a Suprema Corta tenha pacificado o entendimento no sentido de afastar a incidência do Decreto-Lei autoanistiante, a sociedade chilena ainda aguarda a revogação formal do dispositivo ${ }^{19}$. Nas próprias estruturas do Judiciário, registra-se a aplicação de penas brandas aos perpetradores. Mais do que isso, segundo Castro e Almeida (2015, p. 216,217), grupos específicos, a exemplo de indígenas Mapuche e exilados, não possuem suas verdades relatadas até a presente data, e parte das informações extraídas nos informes Rattig e Valech permanecem sob sigilo.

No Chile, assim como na Argentina, apesar dos significativos avanços em determinadas matrizes, também não se verifica o alcance da plenitude democrática, tal como se defende no curso do presente trabalho, persistindo um perene dissenso social que atualmente permite, por exemplo, a escalada de grupos inspirados no regime autoritário ${ }^{20}$.

Além disso, assim como acontece na Argentina, os movimentos sociais, especialmente representados no Chile pelo Agrupamento de Familiares de Detidos Desaparecidos sugere que o Poder Judiciário tem sido benevolente com os agentes do regime Pinochet, reconhecendo a prescrição de crimes que, de acordo com a normativa de Direito Internacional dos Direitos Humanos, não se sujeita à prescrição ${ }^{21}$.

Em todo caso, as manifestações que tomam as ruas clamam pelo fim da impunidade e pelo fim das regalias concedidas aos agentes do regime que já foram condenados, visto que aqueles que cumprem pena, segundo denúncias formuladas pelos movimentos sociais e imprensa chilena foram encaminhados ao presídio de "Punta Peuco" e "Cordillera", onde gozam de regalias que, segundo informe realizado pelo Instituto Nacional de Direitos Humanos do Chile, conta com sala de cinema e quadra de tênis, por exemplo ${ }^{22}$.

\footnotetext{
${ }^{19}$ Promessa a propósito feita pela ex-presidente Michelle Bachelet, mas não cumprida até o fim do seu mandato no final do ano de 2017.

${ }^{20}$ Exemplo cabal disso é o resultado das últimas eleições presidenciais chilenas. No primeiro turno, José Antônio Kast, que é um aberto defensor do regime Pinochet, obteve aproximadamente $8 \%$ (oito por cento) dos votos dos chilenos. O eleito foi Sebastian Piñera, que no segundo turno contou com o apoio explícito de Kast.

${ }^{21}$ Em muitos casos, a solução encontrada pelo Poder Judiciário, é atribuir à prática dos repressores a conduta do "sequestro" e não do "desaparecimento forçado". Por se tratar, então, de um crime de natureza comum, aplica-se a regra usual de prescrição.

${ }^{22}$ Matéria inclusive com registro fotográfico da estrutura de Punta Peuco pode ser acessada através do website do Portal de Notícias Chileno "El Repúblico": https://www.elrepublico.com/pais/25/03/2017/el-hotel-informe realizado por el Instituto Nacional de Derechos Humanos.-de-punta-peuco-por-dentro/. O fechamento da prisão de Puenta Peuco era uma promessa da ex-presidente chilena Michelle Bachelet, que contudo não se cumpriu até o término do seu mandato em Dezembro de 2017. A prisão de "Cordillera", por sua vez, foi fechada no ano de 2013.
} 


\section{O caso brasileiro: A Comissão Nacional da Verdade ou a Comissão da Verdade Possível?}

A Comissão Nacional da Verdade, no Brasil, é resultado de uma série de embates promovidos, especialmente por familiares das vítimas do regime autoritário brasileiro. Ao contrário do que aconteceu em Estados como aqueles dois estudados panoramicamente ao longo deste artigo, a Comissão Nacional da Verdade brasileira somente ganhou projeção e se estabeleceu após aproximadamente 30 (trinta) anos da distensão oficial da ditadura civil-militar.

A ambição desses atores sociais finalmente se concretizou a partir da composição colateral de pelo menos três elementos que derivaram das suas lutas e contribuíram diretamente no tensionamento institucional da questão: i) a inclusão do eixo orientador referente à Memória, Verdade e Justiça no PNDH-3, ii) a problematização ${ }^{23}$ e posterior promulgação da Lei de Acesso à Informação e; iii) a sentença da Corte Interamericana de Direitos Humanos no caso Gomes Lund e Outros vs. Brasil.

Apesar da precedência de tais elementos, o caminho que seguiu até a promulgação da Lei que criou a Comissão Nacional da Verdade foi ruidoso. Nos meses que antecederam a publicação da lei, houve tensões e protestos. Dentre as insatisfações, as mais incisivas publicamente vieram dos clubes militares, como não poderia deixar de ser, registraram através da imprensa sua discordância ${ }^{24}$.

Por outro lado, a tramitação da Lei perante o Congresso Nacional foi permeada por negociações, fruto de um acordo de coalizão. O texto final, assim, somente foi aprovado, após a concordância com alguns destaques feitos pela bancada da então oposição. Na ocasião, o líder do partido "Democratas" 25 , indicou e aprovou uma emenda no sentido de restringir as hipóteses

\footnotetext{
${ }^{23}$ A Lei de Acesso à Informação, apesar de somente ter sido promulgada em 2011, esteve no centro dos debates desde o ano de 2005, especialmente perante o Conselho de Transparência Pública e combate à corrupção. Esta informação pode ser verificada no Portal da Transparência do Governo Federal: http://www.acessoainformacao.gov.br/assuntos/conheca-seu-direito/historico-da-lai

${ }^{24}$ Dentre tantas, a declaração do General da Reserva Marco Antônio Felício da Silva chamou especial atenção. O militar classificou a CNV como um teatro montado pela esquerda armada "(...) colocando-os como democratas e defensores da liberdade e dos direitos humanos quando, no passado, desejavam a derrubada do governo e a instalação de uma ditadura do proletariado por meio da luta armada, usando do terrorismo, assassinatos, roubos, sequestros e justiçamentos". A íntegra da matéria pode ser acessada em: http://politica.estadao.com.br/noticias/geral,militares-reagem-a-declaracao-de-que-investigacao-nao-tem-2lados, 873446 .

${ }^{25}$ O então deputado Antônio Carlos Magalhães Neto é neto do falecido Senador Antônio Carlos Magalhães, político baiano que guardava uma íntima relação com o regime autoritário, tendo sido nomeado prefeito da capital baiana ao final dos anos de 1960 e posteriormente indicado para assumir o governo do Estado por Emílio Garrastazu Médici.
} 
de nomeação dos membros da $\mathrm{CNV}^{26}$, o que atrasou em aproximadamente 6 (seis) meses o início das atividades da Comissão Nacional da Verdade.

Outra relevante questão tratada por força de emenda, e que demonstra a disposição da elite conservadora brasileira em combater os termos da Lei que instituiu a CNV, foi apresentada pelo então líder do Partido da Social Democracia Brasileira - PSDB na Câmara, o deputado Duarte Nogueira, que pretendia incluir no rol de "investigados" os militantes de esquerda e até mesmo órgãos ou governos estrangeiros que, supostamente tivessem “(...) combatido o governo do país durante o período da apuração."27. Referida emenda do Deputado Duarte Neto foi rejeitada sob o argumento de que os militantes de esquerda já haviam sido reprimidos, investigados e julgados perante cortes militares.

Por fim, a aprovação do texto perante o Congresso Nacional foi precedido por um debate acerca da extensão da Lei autoanistiante brasileira. Políticos da ala conservadora exigiam que a redação da lei que instituiria a Comissão Nacional da Verdade garantisse adstrição aos limites da Lei de Anistia. Um retrato exato disso é a disposição do Art. $6^{\circ}$ da referida lei, que limite a atuação da Comissão Nacional da Verdade à Lei n ${ }^{\circ} 6.683 / 79^{28}$.

Vale ressaltar que, na forma de que foi aprovada, a Lei $\mathrm{n}^{\circ} 12.528$ desagradou aos movimentos sociais de luta pela verdade e memória, que em sua grande maioria desaprovou os termos do acordo que possibilitou aquilo que mais tarde seria chamado de "Comissão do Possível" ou "Comissão do Consenso" 29 . Um desses grupos, relacionado no tópico anterior, e considerado um dos mais relevantes na luta da pauta da memória e verdade, o Grupo Tortura Nunca Mais, divulgou artigo em periódico próprio, logo após votação do Projeto de Lei perante a Câmara dos Deputados, classificando a Comissão Nacional da verdade como um "engodo".

\footnotetext{
${ }^{26}$ Nesse sentido, o texto original previa a nomeação de sete membros designados pelo Presidente da República entre brasileiros de reconhecida idoneidade e conduta ética, identificados com a defesa da democracia e institucionalidade constitucional, bem como com o respeito aos direitos humanos. Com a alteração proposta pelo deputado baiano, o Art. $2^{\circ}$ da Lei ganhou um parágrafo que excepcionava as hipóteses de indicação. Assim, não mais poderiam ser indicados: i) aqueles que exercessem cargos em partidos políticos; ii) aqueles que não fossem imparciais; iii) aqueles ocupantes de cargos comissionados ou função de confiança.

27 Emenda $\mathrm{n}^{\circ} 13$ - Plenário. Disponível para visualização na íntegra através do sítio: http://www.camara.gov.br/proposicoesWeb/prop_mostrarintegra?codteor $=923004 \&$ filename $=E M P+13 / 2011+\%$ $3 \mathrm{D} \% 3 \mathrm{E}+\mathrm{PL}+7376 / 2010$.

${ }^{28}$ Nesse sentido a redação do dispositivo: “Art. $6^{\circ}$ : Observadas as disposições da Lei no 6.683, de 28 de agosto de 1979, a Comissão Nacional da Verdade poderá atuar de forma articulada e integrada com os demais órgãos públicos, especialmente com o Arquivo Nacional, a Comissão de Anistia, criada pela Lei no 10.559, de 13 de novembro de 2002, e a Comissão Especial sobre mortos e desaparecidos políticos, criada pela Lei no 9.140, de 4 de dezembro de 1995.".

${ }^{29}$ O termo remete à infeliz definição de "Democracia do Possível" do constitucionalista Manoel Gonçalves Ferreira Filho, autor de sustentação teórica do modelo de governabilidade do regime autoritário. Contudo, na prática, a "Comissão do Possível" é um retrato fiel do modelo de coalizão que se retratou no primeiro capítulo do presente trabalho, cuja expressão era singularizada pelos politólogos da transitologia.
} 
Antes, o texto do projeto estreitava a margem de atuação da Comissão, dando-lhe poderes legais diminutos, fixando um pequeno número de integrantes, negando-lhe orçamento próprio; desviando o foco de sua atuação ao fixar em 42 anos o período a ser investigado (de 1946 a 1988!), extrapolando assim em duas décadas a já extensa duração da Ditadura Militar. Além disso, impede que a Comissão investigue as responsabilidades pelas atrocidades cometidas e envie as devidas conclusões às autoridades competentes, para que estas promovam a justiça. (GRUPO TORTURA NUNCA MAIS, 2011).

A Lei $\mathrm{n}^{\mathrm{o}} 12.528$ também foi alvo de contundentes críticas formuladas por um coletivo de famílias das vítimas do regime autoritário. O "Manifesto das famílias das vitimas da ditadura", veiculado em 19 de setembro de 2011 em alguns órgãos de imprensa, dá conta da insatisfação desses atores sociais que, além de replicarem as críticas formuladas pelo Grupo Tortura Nunca Mais, reclamaram a submissão dos nomes dos membros da Comissão à apreciação dos movimentos sociais: "em particular aos resistentes (militantes, perseguidos, presos, torturados, exilados, suas entidades de representação e de familiares de mortos e desaparecidos). ${ }^{" 30}$.

Nesse contexto, a Comissão Nacional da Verdade finalmente deu início aos seus trabalhos, em 16 de maio de 2012 a partir da cerimônia oficial da sua instalação. Naquela altura, Anthony Pereira (2014), atento às mobilizações dos grupos de pressão existentes nos dois lados, assim observava:

A Comissão da Verdade entra em operação num contexto de alta polarização política e é improvável que agrade a todos. Aparentemente a grande maioria da opinião pública brasileira é cética ou indiferente à Comissão. Os argumentos mais fortes contra a comissão tendem ao realismo político. Assim, se a negociação política que deu início a transição, diz o argumento, foi consensual, também deverá ser a amnésia. (PEREIRA, 2014, p.524) (11 $^{31}$

Da formulação de Pereira, chama atenção, especialmente no recorte metodológico proposto, a narrada indiferença da opinião pública em relação à instalação da Comissão Nacional da Verdade. A questão, que remete parcialmente ao tópico anterior, pode estar relacionada a pelo menos dois fatores: i) o longo lapso temporal havido desde a distensão do regime autoritário e a criação da $\mathrm{CNV}^{32}$ e, ii) o isolacionismo dos movimentos de luta pela

\footnotetext{
30 Ver o "Manifesto das famílias das vitimas da ditadura", de 19 de setembro de 2011, disponível em: https://www.carosamigos.com.br/index.php/gallery/100-outras-noticias/movimentos-sociais/3341-movimentose-sociedade-civil-exigem-alteracao-do-texto-da-comissao-da-verdade.

${ }^{31}$ Tradução livre do original: "The truth Commission is operating in a highly polarized political environment and is unlikely to be able to please everyone. It seems likely that a large portion of Brazilian public opinion is skeptical about or indifferent to the commission. The strongest arguments against the commission tend towards policital realism. The political negotiation that led to the transition, goes the argument, was consensual; so was the amnesy.".

${ }^{32}$ A comissão foi instalada 27 (vinte e sete) anos após a oficial saída do regime autoritário do poder, e o Relatório final foi apresentado no ano de 2014, quando se registrava a passagem de 50 (cinquenta) anos desde o golpe civilmilitar de 1964.
} 
memória e pela verdade, quase sempre endossados ao longo dos anos pelos familiares das vítimas.

Naturalmente, não se pode desconhecer que essa pode ser uma consequência lógica da desmobilização do conjunto da sociedade, provocada pela tradição amnésica própria da experiência brasileira de transição.

Assim, havia na Comissão Nacional da Verdade a necessidade de cumprir um desafio que extrapolava o limite dos seus propósitos legalmente previstos. Havia, desse modo uma necessidade de congregar a opinião pública em torno do tema. Esse engajamento foi intentado através de uma verdadeira imersão da CNV nas mídias sociais ${ }^{33}$.

Para além, talvez o mais relevante ponto de contato da Comissão Nacional da Verdade com os demais segmentos da sociedade tenha sido singularizado na criação de grupos temáticos de trabalho que, além de terem dedicado espaço às investigações relativas às operações e às atividades do regime autoritário, também designou grupos para alcançar as relações da ditadura civil-militar com setores e pautas específicas.

A combinação da análise dessas pautas foi possível em razão da aplicação de uma técnica denominada "Arqueologia da Repressão e da Resistência". Poloni (2014), assim descreve a metodologia:

(...) apresenta-se como um campo de estudos com contexto teórico, metodológico e objeto de estudos próprios, permitindo, através da análise da cultura material humana, a inclusão de um ponto-de-vista alternativo na compreensão tanto de contextos de ocorrência de ações de repressão e de resistência, quanto da ciência produzida em contextos autoritários. (POLONI, 2014, p. 269)

A metodologia disposta, portanto, pretendia não somente difundir o signo da verdade histórica, mas estender o alcance das informações de modo que se pudesse estabelecer um diálogo entre a sociedade e os diversos discursos sobre os contextos repressivos.

A Comissão Nacional da Verdade apresentou seu Relatório Final em dezembro do ano de 2014, e embora tenha trazido no seu bojo relevantes contribuições no desvelamento das graves violações de Direitos Humanos ocorridas no curso da ditadura civil-militar brasileira, destacou igualmente as dificuldades encontradas na produção da sua síntese.

Caso as Forças Armadas tivessem disponibilizado à CNV os acervos do CIE, CISA e Cenimar, produzidos durante a ditadura, e se, igualmente, tivessem sido prestadas todas as informações requeridas (...) a história de execuções, tortura e ocultação de cadáveres de opositores políticos à ditadura militar poderiam ser melhor elucidadas. (COMISSÃO NACIONAL DA VERDADE, 2014, p .28, v.III).

\footnotetext{
${ }^{33}$ A Comissão Nacional da Verdade dispunha de contas nas redes sociais como "Twitter", "Facebook", além de um sítio virtual interativo e uma conta no website de compartilhamento de vídeos "You Tube".
} 
A dificuldade narrada autoriza interpretar que, de todo modo, o trabalho da Comissão Nacional da Verdade tem raiz em duas escolhas metodologicamente feitas pelo grupo: i) a dedicação excessiva aos documentos e; ii) o objetivo de dar à história oral um caráter de "história oficial". Embora o caminho seja legítimo, pode-se afirmar, resgatando a conceituação de memória, verdade e empoderamento já construída no segundo capítulo deste trabalho, que tal opção permite repousar a vítima numa mesma condição de vítima, recusando um engajamento pela dialética e um aprofundamento democrático (WEICHERT, 2014b, p. 114). Ainda segundo Cunha de Oliveira (2015):

\begin{abstract}
No acompanhamento das vítimas, principalmente na passagem dessa condição para a de sujeitos de ação, é imprescindível acolher histórias, criar caminhos de coletivização, criar juntos, saber cuidar. Trabalhar com a transdisciplinaridade e com as invenções coletivas, para a transformação das instituições públicas, de ambientes "totais" para "instituições permeáveis". (CUNHA DE OLIVEIRA, p.171)
\end{abstract}

Por outro lado, merece destaque as importantes recomendações apontadas pelo colegiado que sugere, ao fim do trabalho, que o Estado brasileiro adote uma série de medidas para pôr fim ao legado autoritário ${ }^{34}$. Dentre as vinte e nove recomendações contidas no Relatório da Comissão Nacional da Verdade, destacamos as seguintes: i) Estabelecimento de órgão permanente com atribuição de dar seguimento às ações e recomendações da CNV; ii) Prosseguimento das atividades voltadas à localização, identificação e entrega aos familiares ou pessoas legitimadas, para sepultamento digno, dos restos mortais dos desaparecidos políticos; iii) Preservação da memória das graves violações de direitos humanos; iv) Prosseguimento e fortalecimento da política de localização e abertura dos arquivos da ditadura militar.

Ademais, outra relevante contribuição realizada pela Comissão Nacional da Verdade, relaciona-se com o engajamento que promoveu nos demais órgãos do Estado brasileiro, universidades, sindicatos, conselhos de classe, entre outros, que por sua vez, instalaram Comissões próprias (Estaduais, municipais e setoriais) para apurar violações ocorridas no âmbito desses espaços, chegando a articular ações com a própria Comissão Nacional da Verdade.

O fato, contudo, é que entre 1985 e 2015, o Brasil viveu a promessa da "redemocratização", e acumulou a esperança pulsante de uma democracia que fosse capaz de se consolidar, tornando-se rígida para enfrentar eventuais intempéries. Durante esse período, as

\footnotetext{
${ }^{34}$ Constam, ao fim do Relatório, 29 (vinte e nove) recomendações propostas pelo colegiado. As recomendações variam desde a internalização de políticas públicas à adoção de medidas reparatórias de um modo geral.
} 
lutas pela transição foram se acirrando, na medida em que as conquistas - mesmo que modestas - surgiam no horizonte.

Um dos mais esperados momentos de ascensão da jovem democracia brasileira, a realização do Direito à Memória e à verdade através da sua Comissão Nacional e a possibilidade de construção de uma identidade coletiva autônoma, despregada do discurso do autoritarismo, imune aos retrocessos em matéria de Direitos Humanos, parece ter sido representada efetivamente como Comissão da Verdade Possível.

No modelo brasileiro, portanto, é possível reconhecer que há uma perniciosidade no tencionamento permanente por um modelo de transição que não permita contrariar as forças hegemônicas $^{35}$, para daí inaugurar um paradigma sócio-histórico pautado no dever de construção de uma democracia de alta intensidade ${ }^{36}$.

\section{Conclusão}

Ao fim do presente artigo, é possível constatar que sob o ponto de vista da análise histórica, a experiência latina notabilizou-se, de forma marcante, pelos arranjos institucionais, mas por outro lado também pelas resistências dos seus povos, sugerindo o dissenso social que de alguma maneira redimensiona a busca pela realização dos direitos da transição.

A intensidade das lutas parece ter sido decisiva para que os movimentos de consagração do direito à memória e à verdade pudessem se afirmar especialmente na Argentina e no Chile, malgrado as duas experiências também apresentem as suas incongruências.

Por outro lado, analisando as práticas dos Estados, é possível afirmar que empoderar a sociedade através da garantia do direito à memória e à verdade significa dar início à construção de uma compreensão que seja capaz de lidar com os desafios impostos pelo legado autoritário de uma maneira assertiva, distinta do que propõem os modelos ratificadores dos acordos políticos celebrados em prol de uma cultura do esquecimento.

Em que pesem as dificuldades enfrentadas pelas sociedades argentina e chilena, o presente artigo demonstrou que há uma disposição estabelecida naqueles Estados e que, diante do estímulo de uma cultura de promoção do direito à memória e à verdade, mantém acesa a necessidade de problematização em torno da questão.

\footnotetext{
${ }^{35}$ Os acordos e concessões feitos quando da promulgação da Lei que instituiu a Comissão Nacional da Verdade é uma prova cabal de que os interesses hegemônicos ainda apresentam grande relevância e contato na dinâmica das lutas pela transição.

${ }^{36} \mathrm{Ou}$ seja, como diz Sousa Júnior (2015), uma democracia que se alicerça na medida em que a práxis social seja reconhecida como consagradora de direitos capaz de subverter o monismo estatal, conferindo protagonismo aos movimentos sociais e outros sujeitos tradicionalmente negados e invisibilizados por um padrão burocrático institucional que é hegemônico.
} 
Sousa Junior (1997, p. 99) afirma que a perspectiva democrática é também uma experiência de recriação permanente e de renovação das instituições que resulta na determinação de novos espaços públicos e condições para o debate e formação de novos consensos. Ao que tudo indica, falta ao modelo brasileiro de resgate da memória e da verdade, a formação de um novo consenso.

Ao apresentar a experiência brasileira de memória e verdade, o presente trabalho demonstrou que a construção da Comissão Nacional da Verdade, cujos anseios povoaram as pautas dos grupos de vítimas e familiares, ao longo de mais de três décadas, se constituíram na forma da Comissão do Possível, relembrando o infeliz acordo que possibilitou o início da transição com a promulgação da Lei de Anistia.

Assim como o processo de "redemocratização" brasileiro, a constituição da Comissão Nacional da Verdade se deu mediante negociação com os mesmos representantes das forças do autoritarismo, de modo que o seu modo de atuação passou a dispor de limites muito claros, que dificultaram de sobremaneira os seus trabalhos, desde a formação do seu quadro de comissionados, até a impossibilidade da coleta de dados junto aos órgãos das Forças Armadas brasileiras.

Contudo, apesar da incompletude da experiência brasileira, o presente trabalho evidenciou que a existência da centelha pode ser o começo para que se institua uma agenda permanente pela ampla fixação do direito à memória e à verdade dentro do espectro de defesa das agendas de Direitos Humanos. Ainda que a consolidação de tal direito pareça tardia, o seu efeito parece definitivo para a construção de uma democracia de alta intensidade.

\section{Referências bibliográficas}

ARGENTINA. Decreto Ley 187/1983, de 19 de Diciembre de 1983. Comisión Nacional sobre la desaparición de personas - Constitucición - Integración y funciones. Disponível em http://www.derechos.org/ddhh/arg/ley/conadep.txt. Acesso em 4 de Nov. de 2017.

ARGENTINA. Lei 23.492, de 24 Diciembre de 1986. Ley de punto final. Dispónese la extinción de acciones penales por presunta participación, en cualquier grado, en los delitos del artículo 10 de la Ley $\mathrm{N}^{\mathrm{o}} 23.049$ y por aquellos vinculado a la instauración de formas violentas de acción política. Excepciones. Disponível em http://www.infoleg.gov.ar/ infolegInternet/anexos/20000-24999/21864/norma.htm. Acesso em 4 de Nov. de 2017. 
ARGENTINA. Lei 23.521, de 8 de junio de 1987. Ley de obediência debida. Obediencia debida. Se fijan límites. Disponível http://www.infoleg.gob.ar/infolegInternet/anexos/2000024999/21746/norma.htm. Acesso em 4 de Nov. de 2017.

BRASIL. Lei n⿳ 6.683, de 28 de janeiro de 1979. Concede Anistia e Dá Outras Providências. Brasília, DF, Disponível em: <http://www.planalto.gov.br/CCivil_03/leis/L6683.htm>. Acesso em: 10 de set. 2017.

BRASIL. Lei no 12.528, de 18 de novembro de 2011. Cria a comissão nacional da verdade, no âmbito da Casa Civil da Presidência da República. Diário Oficial [da] União, Brasília, 18 nov. 2011. Disponível em: <http://www.planalto.gov.br/ccivil_03/_Ato2011-2014/2011/ Lei/L12528.htm>. Acesso em: 17 ago. 2017.

BRASIL. Comissão Nacional da Verdade. Relatório. Brasília, 2014. (Relatório da Comissão Nacional da Verdade; v.1). Disponível em: < http://www.cnv.gov.br/images/pdf/relatorio/ volume_1_digital.pdf>.Acesso em: 15 ago. 2017.

CASTRO; Juliana Passos; ALMEIDA, Severino Moraes. Justiça Transicional: o modelo chileno José Geraldo de et. al (Orgs.). O direito achado na rua : introdução crítica à justiça de transição na América Latina. Brasília, DF: UnB, 2015.p. 249-256.

CHILE. Decreto Ley 2191, de 18 de abril de 1978. Concede amnistia a las personas que indica por los delitos que señala. Disponível em http://www.usip.org/sites/default/files /file/resources/collections/commissions/Chile90-AmnestyLaw_decree2191.pdf. Acesso em: 24 nov. 2017.

CHILE. Decreto Supremo no 355, de 24 de abril de 1990. Informe de la Comisión Nacional de Verdad y Reconciliación. Chile, 1996. Disponível em: http://pdh.minjusticia.gob.cl/wpcontent/uploads/2015/12/Creacion-Comision-Rettig.pdf. Acesso em 23 de mar. de 2017.

\section{CHILE. Informe de la Comisión Nacional sobre Prisión Política y Tortura (Valech I).}

Chile, 2010. Disponível em: https://www.indh.cl/destacados/comision-valech/. Acesso em 24 de mar. de 2017. 
COGGIOLA, Oswaldo. Governos militares na América Latina. São Paulo: Contexto, 2001.

CUNHA DE OLIVEIRA, Roberta. Entre as geografias violadas e a resistência pelo testemunho, a necessária ruptura para a transição brasileira. In Sousa Junior, José Geraldo de et. al (Orgs.). O direito achado na rua : introdução crítica à justiça de transição na América Latina. Brasília, DF: UnB, 2015.

FRUHLING, Hugo. Nonprofit Organizations as opposition to Authoritarism Rule: The Case of Human Rights organizations in Chile in The Nonprofit sector in International perspectivs. Estelle James (Org). Ed. Oxford University, New York, 1989. p. 358-376.

GRUPO TORTURA NUNCA MAIS (Rio de Janeiro). COMISSÃO DA VERDADE: mais uma farsa, mais um engodo. 2011. ANO 25 - N77. Disponível em: $<$ http://www. torturanuncamais-rj.org.br/jornal/gtnm_77/comissao_verdade.html>. Acesso em: 01 jun. 2017.

MARIASCH, Telma Lilia. As lutas por verdade e justiça na Argentina contemporânea: uma cartografia. Tese de doutorado. ESS/UFRJ. Disponível em: http://www.

dominiopublico.gov.br/pesquisa/DetalheObraForm.do?select_action=\&co_obra=14507. Acessos em 15 de nov. de 2017 e 06 de dez. de 2017.

MEDICI, Alejandro. EI movimiento de derechos humanos en la Argentina y su lucha contra la impunidad: la estrategia del "escrache". Disponível em: http://www.dhnet.org.br/dados/lex/a_pdf/medice_escrache.pdf, 2007. Acesso em: 14 out. 2017.

ORELLANO, Patrício; HUTCHISON, Elizabeth Quay. El movimiento de derechos humanos en Chile, 1973 - 1990. Santiago: Centro de Estudios Politicos Latinoamericanos Simh Bolivar, 1991.

PEREIRA, Anthony. Political (In)justice: Authoritarianism and the Rule of Law in Brazil, Chile, and Argentina. Pittsburgh: University of Pittsburgh Press, 2005. 
PEREIRA, Anthony. Brazil's Truth Comission: Opportunities and risks. In: Inês Virginia Prado et al (Orgs.) Direitos Humanos Atual. Rio de Janeiro: Elsevier, 2014. pp 518-526.

PITA, M. Violencia policial y demandas de justicia: acerca de las formas de intervención de los familiares de víctimas en el espacio público. In: TISCORNIA, S. (comp.), Burocracias y violencia: estudios de antropología jurídica. Buenos Aires: Antropofagia, 2004.

POLONI, Rita Juliana Soares. Arqueologia da Repressão e da Resistência: Uma Proposta de Estudo, história e-história, curtas, 05.02.2014. Disponível em: http://www.historiaehistoria.com.br/materia.cfm?tb=curtas\&id=118, acesso em 10 de out. 2017.

QUIJANO, Aníbal. Colonialidad del poder, eurocentrismo y América Latina. In: LANDER, Edgardo (org). La conolialidad del saber: eurocentrismo y ciencias sociales, perspectivas latinoamericanas. Buenos Aires: CLACSO, 2000. p.193-238.

RAMOS, Thaís. A participação social deliberativa na constituição da verdade sobre as violações de Direitos Humanos do Regime Militar brasileiro. Dissertação (Mestrado em Direito) - Universidade de Santa Cruz, Santa Cruz do Sul, 2012. Disponível em: http://unisc.br/portal/images/stories/mestrado/direito/dissertacoes/2013/tais-ramos.pdf. Acesso em 8 de maio. de 2017.

RICOEUR, Paul. O justo. São Paulo: Martins Fontes, 2008.

SOUSA JUNIOR, José Geraldo de. Novas Sociabilidades, novos conflitos, novos direitos. In: PINHEIRO, José Ernanne; SOUSA JUNIOR, José Geraldo de; DINIZ, Melillo e SAMPAIO, Plínio de Arruda (Org.). Ética, Justiça e Direito. 2a ed. Petrópolis: Vozes, 1997.

SOUSA JUNIOR, José Geraldo de (Coord.). O Direito Achado na Rua: concepção e prática. Rio de Janeiro: Lumen Juris, 2015.

WEICHERT, Marlon Alberto. O relatório da Comissão Nacional da Verdade: conquistas e desafios. Revista Projeto História: Memória, Ditaduras \& Direitos, São Paulo, n. 50, maio/ago. 2014b. 


\title{
DIREITOS HUMANOS FUNDAMENTAIS, DEMOCRACIA E POLÍTICAS ECONÔMICAS
}

\author{
Ricardo Antonio Lucas Camargo \\ UFRGS \\ Maria Cristina Cereser Pezzella \\ UFRGS e Unoesc
}

\section{Resumo}

O presente ensaio propõe-se a retomar, a partir do diálogo com Rui Barbosa e Washington Peluso Albino de Souza, as noções que relacionam os "sistemas econômicos", o "ordenamento jurídico" e a "política econômica", demonstrando o quanto o Estado Social, seja na sua vertente democrática, seja na sua vertente autoritária, ainda procura responder às questões relacionadas ao título de legitimação dos sistemas baseados na propriedade privada e na liberdade contratual, mesmo no contexto da "sociedade da informação". Empregado o método dedutivo, mercê do qual cada uma das proposições lançadas é decorrência de uma proposição mais geral e que apresenta um elo de causalidade anterior, vai-se analisando o discurso que procura aplicar aos direitos humanos fundamentais o conceito econômico de "commodity", seu papel nas alterações feitas à Constituição brasileira de 1988 e o entendimento do Supremo Tribunal Federal acerca dos limites ao poder de emenda, realizado, a partir de então, o exame da Emenda Constitucional n. 95, de 2016, voltada a priorizar o pagamento da dívida pública diante dos demais encargos financeiros do Estado, reduzindo o comprometimento financeiro com a realização dos direitos sociais.

Palavras-chave: Estado Social, sociedade da informação, política econômica, emendas constitucionais.

\section{Abstract/Resumen/Résumé}

This essay proposes to retake, through a dialogue with Rui Barbosa and Washington Peluso Albino de Souza, the notions that relate the "economic systems", the "legal system" and the "economic policy", in order to show how the Social State, either in its democratic branch, or in its authoritarian one, still seeks to answer the questions regarding the legitimacy of systems based upon private property and contractual freedom, even in the context of the "information society". In applying the deductive method, in which each one of the propositions casted is 
consequence of a general proposition and which presents a bring to a prior causation, it is analyzed the speech that seeks to apply to fundamental human rights the economic concept of commodity, its role in alterations made to the Brazilian Constitution of 1988 and the rationale of the Supermo Tribunal Federal upon the limits given to the amendment power, through, at the time, the assessment of the Constitutional Amendment n. 95 of 2016, aimed to give priority to the payment of the public debt facing the other financial burdens of the State, and thus, reducing the financial commitment to the fulfillment of social rights.

Keywords/Palabras-claves/Mots-clés: Social State, information society, economic policy, constitutional amendments.

\section{Introdução}

Quando se abatem crises econômicas em países não integrantes do denominado "Primeiro Mundo", é comum o apelo a formas salvacionistas, que começam, invariavelmente, pelo discurso de "remoção dos obstáculos jurídicos ao sucesso dos planos de salvação nacional". No Brasil, em especial, como sabem quantos têm acompanhado os últimos acontecimentos, tal proposição calha às maravilhas. Como se trata de tema marcado pelas polarizações, mesmo que não se possa dizer que o trabalho que vai ser trazido ao debate seja "neutro", no sentido de uma tomada de posição, a preocupação que nele se espelha é a de resgatar, pelo menos, os conceitos e os precedentes que mereceriam ser tomados em consideração.

\section{2. "Reforma do Estado", "sistemas econômicos", "Constituição"}

Todas as vezes em que se traz ao debate a questão do "tamanho do Estado", o que subjaz são as características do "sistema econômico". Sem qualquer vinculação com os pressupostos do "materialismo histórico", tal debate, com efeito, traz à baila a questão das posições que os seres humanos assumirão diante dos meios aptos à satisfação das respectivas necessidades, bem como do modo de disciplinar as atividades que irão desenvolver para satisfazê-las, o que implica discutir os modos de disciplinar a apropriabilidade dos bens, as possibilidades de uso destes, as possibilidades de alguém servir-se, ou não, para acessar os bens, do dispêndio de energia física e mental alheia, dos frutos passíveis de serem gerados pelas atividades que sejam desenvolvidas e dos pressupostos da acessibilidade de tais frutos. 
"As consequências econômicas do direito de propriedade são o principal dado da própria configuração dos regimes e sistemas de vida dos povos" (SOUZA, 2002, p. 154.).

Os sistemas econômicos, na expressão weberiana, constituem "tipos ideais", que irão permitir compreender, em abstrato, as diversas formas por que se manifestará o tratamento da propriedade, da exploração dos bens, da acessibilidade a estes, da utilização respectiva, bem como do trabalho:

"A identificação dos campos que incumbem ao particular e ao 'Poder Público' dependerá da configuração das 'relações econômicas', isto é, do 'modo de ser recíproco' entre os entes que se movimentarão em direção à satisfação das respectivas necessidades em um determinado ambiente e, enquanto 'tipo ideal', corresponderá a um 'sistema econômico'.

"O 'sistema econômico', como se sabe, jamais se manifesta em sua forma 'pura', presentes elementos característicos de 'sistemas' diferentes na configuração das relações econômicas"(CAMARGO, 2015, p. 87).

No contexto da "sociedade da informação", quando os contratos passam a, mais do que nunca, a ultrapassar as fronteiras dos Estados e o capital passa a cada vez mais dispensar o concurso do trabalho, a modificação do sistema econômico no sentido do reforço da propriedade privada, da restrição do conceito de serviços públicos, da ampliação do conceito de "commodities", da diminuição dos direitos econômicos, sociais e culturais, bem como dos direitos de solidariedade (PEZZELLA, 2014, p. 255-6), passa, necessariamente, pela modificação da Constituição Econômica, isto é, do tratamento do dado econômico no bojo das Constituições.

Como não existem relações de poder que valham por si mesmas, como precisam elas, antes, buscar legitimação - porque, a rigor, como é próprio do ser humano autoafirmar-se (SMITH, 2002, p. 289; RICARDO, 1937, p. 49-50), ninguém se põe numa posição de subordinação a outrem sem que exista um motivo forte, que pode variar desde a obtenção da própria subsistência até mesmo ao temor de perder a vida (WEBER, 1992, p. 43; FOUCAULT, 1992, p. 272; BERLE, 1961, p. 127; BOBBIO, s/d, p. 176-7; AZEVEDO, 1983, p. 64; SOUZA, JÚNIOR, 2002, p. 55) -, não é raro que os motivos para a legitimação provenham de uma ampla propaganda, no sentido, ou de apontar para um bem a ser alcançado ou para um mal a ser evitado. Tal tem ocorrido, no Brasil, para procurar legitimar reformas constitucionais em relação aos direitos trabalhistas, à previdência e, mesmo, à própria definição dos campos da atividade econômica e dos serviços públicos, qualificando como "técnicas" as posturas favoráveis a tais reformas, voltadas à redução de tudo o que represente gravames para as classes proprietárias ou o aumento de espaços para os integrantes da massa dos menos aquinhoados patrimonialmente e de "ideologicamente comprometidas com o esquerdismo" quaisquer proposições que pretendam submeter a crítica as alegações da natureza benfazeja e da imprescindibilidade das reformas 
serem aprovadas, pondo como mote inarredável o combate ao déficit público (JORNAL DO BRASIL, 2016).

Não deveria, a rigor, ser necessário recordar em um texto científico que a aceitação de determinadas premissas, principalmente fácticas, não implica, inexoravelmente, a condição de militância em tal ou qual causa. Entretanto, nos tempos atuais, a credibilidade parece depender do enquadramento "ideológico" - aqui, no sentido vulgar, de "ismo", que não deve ser corrente no âmbito científico - ou "partidário", e torna-se indispensável para que uma mensagem possa ser, no mínimo, ouvida, realizar a demonstração de que ela transcende determinadas identidades.

\section{Rui Barbosa, a "propaganda socialista" e os direitos sociais}

Quando se trazem pronunciamentos no sentido de que tratar, por exemplo, as questões relacionadas ao trabalho como insuscetíveis de serem relegadas exclusivamente à livre contratação entre as partes seria "propaganda socialista", cabe apenas recordar antigo ensinamento de Rui Barbosa (1849-1923), autor, em grande parte, do texto da Constituição liberal que vigorou no Brasil de 1891 até 1930:

\footnotetext{
"Senhores, socialista é o adepto do socialismo, e o socialismo é uma teoria, um sistema, um partido. No socialismo, pois, como em todas as crenças de partido, em todos os sistemas, em todas as teorias, há um fundo verdadeiro com acessórios falsos, ou um fundo errôneo com acessórios justos. Os teoristas, os sistemáticos, os partidistas não discriminam entre o grau de verdade e a liga de erro que a inquina, ou entre a base de erro e a superfície de verdade que a recobre, e, amalgamando tudo numa só doutrina inteiriça, estiram a verdade, por exageração, até os limites do erro como consequência insuperável do consentimento à verdade.

"Eis por que, senhores, grave desacerto me parece reduzir a boa causa operária a uma dependência essencial da sistematização socialista" (BARBOSA, 1919, p. 80).
}

Sim, o que dizia o grande jurisconsulto e político baiano era não ser necessário professar o credo socialista, em qualquer de suas vertentes, para se reconhecer a existência de uma questão social, sem a reduzir a um "caso de polícia" (HAYEK, 1985, p. 184), ou à recompensa pela inépcia ou preguiça dos que não foram beneficiados pelo sistema de mercado (SMITH, 1996, p. 343; HUME, 1982, p. 212; RICARDO, 1937, p. 62; MALTHUS, 1996, p. 340.). Claro que, aqui, está posta uma proposição contrária ao liberalismo econômico "em estado puro", uma vez que, para este, os interesses do trabalhador e do empregador, do fornecedor e do consumidor, estariam em condições de igualdade entre si, e os respectivos contratos seriam 
fruto da vontade livremente manifestada, com as concessões que cada qual, nos limites da respectiva conveniência, assumiu (PRUNES, 1999, p. 402.).

Poder-se-ia dizer, então, que estaríamos diante de um compromisso com uma outra vertente antiindividualista de matiz mais "conservador", raiz do pensamento tecnocrático, que seria o positivismo filosófico, inspirador tanto de Júlio de Castilhos quanto de seus herdeiros intelectuais e políticos Borges de Medeiros, Flores da Cunha e Getúlio Vargas?

\footnotetext{
Novamente, cabe dar a palavra a Rui Barbosa:

"Não será preciso, também, ter lido Comte, para discernir que, quando se fala em 'medidas reclamadas pela questão social', o em que se agita não é em cumprir tais contratos, mas em dar, fora desses contratos, acima deles, sem embargo deles, por intervenção da lei, garantias, remédios, que, contratualmente, o trabalho não conseguiria do capital" (BARBOSA, 1919, p. 110.).
}

Quer dizer, no ver do principal referencial dos juristas brasileiros, a constatação de que, para se falar em liberdade contratual, efetiva, seria necessário que se estivesse diante de partes com igual poder de barganha, que os polos da relação estivessem efetivamente equilibrados, também não demandaria esposar-se o ideal positivista para ser feita.

Poder-se-ia dizer que estaria a fala do "Águia de Haia" a pressupor o conceito de antagonismo entre classes e, de fato, o pressupõe. Entretanto, pode-se verificar que a aproximação com o socialismo - que, consoante demonstrado anteriormente, estava completamente fora da sua visão de mundo - vai somente até aí, recordando, mais, que a própria noção do "conflito entre as classes" como um dado efetivamente existente já se apresentava em clássicos do liberalismo (SMITH, 1996, p. 118-9; MILL, 1965, p. 182; RICARDO, 1937, p. 69; MALTHUS, 1996, p. 253-4). Com efeito, ao versar especificamente o tópico acerca do conflito, ao invés de postular a respectiva exacerbação, como situação que levaria o sistema capitalista a destruir-se a partir de si próprio, como ocorrera com os que o antecederam, postula, antes, o respectivo arrefecimento:

"Não é maior o antagonismo entre o capital e o trabalho que o das nações umas com as outras, e, se entendermos que o bem da humanidade exige a redução do antagonismo entre as nações, não atino por que será que não devamos trabalhar, igualmente, com toda a nossa consciência, pela nossa atenuação do antagonismo entre o trabalho e o capital" (BARBOSA, 1919, p. 117-8).

É importante, apesar da obviedade aparente, observar que, quando se fala em "atenuar o antagonismo", precisa-se ter o antagonismo como existente, ou não haveria por que proceder à respectiva atenuação, cabendo lembrar que "o verbo é uma indicação de alguma coisa predicada de alguma coisa, quer dizer, de alguma coisa predicada num sujeito ou encontrada neste" (ARISTÓTELES. 2010, p. 83). 


\title{
4. A "superação" do trabalho pelo avanço do capitalismo?
}

Claro que existe um fator que os pensadores dos séculos XVIII e XIX, e mesmo Rui, não tomaram em consideração, que é a possibilidade de uma empresa funcionar sem empregar a quem quer que seja, somente auferindo lucros. O exemplo mais evidente do que se diz, aqui, é precisamente o das holding companies puras, cujo único objeto é a participação no capital de outras sociedades, com o fito de obtenção de lucros, como o prevê, entre nós, o $\S 3^{\circ}$ do artigo $2^{\circ}$ da Lei 6.404, de 1976 (CARAVALHOSA, 2013, v. 1, p. 82-3). De outra parte, o fortalecimento do capital não implica, necessariamente, fortalecimento do setor produtivo:

“A desregulamentação financeira, que o programa neoliberal postula, criou condições muito mais propícias para a inversão especulativa do que produtiva, ensejando a prática de um volume astronômico de transações puramente monetárias" (GRAU, 2010, p. 48.).

Por outro lado, a diversificação de setores - inclusive a convivência do investimento nos setores especulativo e produtivo - não constitui novidade. Já na década de 70 do século $\mathrm{XX}$, veio o seguinte pronunciamento:

\begin{abstract}
“A severa experiência de 1929 deu ensejo a um novo tipo de concentração de empresas no mundo capitalista, com a chamada integração complementar, ou conglomerado. Ao revés do que acontece na concentração clássica - horizontal ou vertical - em que o grupo empresarial permanece no mesmo setor econômico, o conglomerado representa a diversificação de participações financeiras nos mais variados mercados. Com essa dispersão dos riscos operacionais, atenuam-se as flutuações cíclicas, ou setoriais, assegurando-se ao grupo econômico uma expansão regular e grande capacidade financeira, em qualquer setor onde opere" (COMPARATO, 1970, p. 6-7.).
\end{abstract}

Num mundo reduzido à disputa de mercado entre as grandes empresas, a substituição do ordenamento estatal por um grande mecanismo de relações atomizadas em contratos, a denominada lex mercatoria, talvez tivesse como se operar (GRAU, 2010, p. 276.). Entretanto, o desaparecimento do trabalho enquanto fator de produção é meramente aparente:

\footnotetext{
"Ao recorrer a expedientes que se antepõem à rigidez contratual, os juslaboralistas confessam dificuldades para o tratamento do tema em sede de Direito do Trabalho, ou seja, do modelo anterior ao pós-moderno. Realmente, aí situam-se expedientes que ficam mais bem situados na área do Direito Econômico, a 'terceirização', a 'flexibilização', em que o tema é tratado dentro da normalidade, não em sentido de solução de crise, como no Direito do Trabalho.
}

"Note-se que, se numa primeira identificação da denominada 'sociedade sem emprego' seria a abolição da submissão do empregado ao empregador, ambos continuam submetidos ao mercado de trabalho como agentes econômicos de mútuos interesses, assumindo característica liberal, pela falta de tutela do Estado e pelo descompromisso do empregador com a garantia de emprego e suas consequências, tais como estabilidade, férias e assim por diante. Alegam tais autores que o desaparecimento dos 'cargos' é sintoma de mutação sócio-econômica mais profunda, pois 'nenhum programa de emprego vai trazer os cargos de volta, eis que a tecnologia afeta mais diretamente o emprego pela maneira como manda a execução do trabalho 
em si'. Tais modificações passam pela 'informatização do ambiente de trabalho', o 'negócio de dados' e a 'tecnologia das informações'. Com esses elementos, desparece a necessidade do 'escritório localizado', existe disponibilidade pronta dos dados nos repositórios eletrônicos e as comunicações realizam as multiplicações destes e de todos os elementos necessários para a tomada de decisões, tornando-a mais ágil" (SOUZA, 2005, p. 480-1.).

Por outras palavras, embora o trabalho humano venha a ter reduzida a sua importância para o desenvolvimento da atividade empresarial, isto não significa que ele venha a desaparecer, nem mesmo na sua modalidade subordinada: frequentemente, a holding participa do capital de empresas atuantes nos setores primário e secundário, nos quais a mão de obra humana é inexoravelmente presente. Vale dizer, para que se implementasse a lex mercatoria, seria mister que todos os interesses em disputa pelo seu "espaço" no mercado tivessem igual pujança, e isto somente seria possível em um mundo em que cada pessoa física somente correspondesse a um órgão de macroempresas, supondo, ainda, que a capacidade de autofinanciamento de todas elas seria rigorosamente igual (COMPARATO, Fábio Konder. Aspectos jurídicos da macroempresa. São Paulo: Revista dos Tribunais, 1970, p. 21.), o que, pelo menos no presente momento, não corresponde à realidade concreta nem mesmo nos países de capitalismo mais avançado.

Admitido que nem todas as pessoas físicas - "pessoas humanas", para se dizer com maior clareza - estão convertidas em órgãos de macroempresas, ainda mais num contexto de Terceiro Mundo, como é o brasileiro, permanece pleno de atualidade o ensinamento segundo o qual os direitos sociais "valem como pressupostos do gozo dos direitos individuais na medida em que criam condições materiais mais propícias ao auferimento da igualdade real, o que, por sua vez, proporciona condição mais compatível com o exercício efetivo da liberdade" ${ }^{1}$. Por sinal, a questão dos direitos sociais como aptos a implementarem uma efetiva igualdade que compense o desequilíbrio nas relações sociais, especialmente trabalhistas, já foi reconhecida pelo Supremo Tribunal Federal ${ }^{2}$.

\footnotetext{
${ }^{1}$ SILVA, José Afonso da. Curso de Direito Constitucional positivo. São Paulo: Malheiros, 2012, p. 287.

${ }^{2}$ BRASIL. Supremo Tribunal Federal. Recurso extraordinário 658.312/SC. Relator: Ministro Dias Toffoli. DJ-e 9 fev 2015.
} 


\section{5. "Direitos sociais" e "cláusulas pétreas" na jurisprudência do Supremo Tribunal Federal}

Caso se tenha como adequado o entendimento segundo o qual os direitos sociais constituem pressuposto da viabilização, a quantos estejam sob o âmbito de vigência do ordenamento constitucional brasileiro, da fruição dos direitos individuais, entendimento que somente é questionado pelos que ainda se mantêm fiéis doutrinariamente ao constitucionalismo liberal clássico e que jamais deixaram de manifestar seu desconforto com o abandono de tais cânones pelas Constituições brasileiras, mormente a de 5 de outubro de $1988^{3}$, tem-se que uma eventual supressão dos direitos sociais pode ter como efeito subtrair a uma parte considerável da população a possibilidade de fruir determinados direitos individuais. Por exemplo, suprimido que fosse o direito à moradia, previsto no artigo $6^{\circ}$ da Constituição brasileira de 1988, o direito individual à inviolabilidade da casa de moradia, presente no inciso XI do artigo $5^{\circ}$ da mesma Constituição, seria restrito tão-somente aos indivíduos que tivessem situação patrimonial que lhes permitisse adquirir a propriedade do imóvel ou pagar o aluguel de imóvel alheio, porque só se pode dar a qualificação de "inviolável” a uma moradia que, efetivamente, se exerça. Doutrinariamente, tem-se seguido no Brasil, majoritariamente, a tese que considera os direitos fundamentais como manifestação da dignidade, inerente a todo ser humano, enquanto pessoa, consoante demonstra pesquisa minudente ${ }^{4}$. Há, inclusive, direitos em relação aos quais se arredaria a própria discricionariedade administrativa no tocante à escolha do momento da respectiva implementação, como é o caso da educação, segundo decidiu o Supremo Tribunal Federal ${ }^{5}$. Daí, perfeitamente possível extrair o corolário segundo o qual, quando o inciso IV do $\S 4^{\circ}$ do artigo 60 da Constituição Federal interdita a própria submissão a deliberação do Congresso Nacional de proposta de emenda constitucional tendente a abolir direitos e garantias individuais, estariam abrangidos em tal interdição os meios indispensáveis à respectiva efetivação, dentre eles, os próprios direitos sociais (FERRARI, 2011, p. 322-3; SARLET, , 2007, p. 122, nota 319; BARROSO, 2012, p. 200-1, nota 64; HORTA, 2010, p. 86; FERREIRA FILHO, 2015, p. 328.), tendo tal tese logrado aceitação pelo Supremo Tribunal Federal (BRASIL. Supremo Tribunal Federal. 2003.). E, quanto àqueles que dependessem de

\footnotetext{
${ }^{3}$ FERREIRA FILHO, Manoel Gonçalves. Curso de Direito Constitucional. São Paulo: Saraiva, 2015, p. 40; HORTA, Raul Machado. Direito Constitucional. Belo Horizonte: Del Rey, 2010, p. 36.

${ }^{4}$ SARLET, Ingo Wolfgang. Dignidade da pessoa humana e direitos fundamentais na Constituição Federal de 1988. Porto Alegre: Livraria do Advogado, 2007, p. 45.

${ }^{5}$ BRASIL. Supremo Tribunal Federal. Agravo regimental no recurso extraordinário 603.575/SC. Relator: Min. Eros Grau. DJ-e 13 maio 2010.
} 
implementação via políticas públicas, como no caso da disponibilização de leitos para pacientes que necessitassem de internação hospitalar (BRASIL. Supremo Tribunal Federal. 2014.) ou da manutenção de assistência à saúde em prol de criança e adolescente (BRASIL. Supremo Tribunal Federal. 2014.) ou do atendimento a crianças menores de cinco anos de idade em creches (BRASIL. Supremo Tribunal Federal. et 2011.), chegou mesmo o Supremo Tribunal Federal a versar a questão da proibição do retrocesso, isto é, uma vez iniciada a implementação do direito em tela, não poderia haver movimentação no sentido de desarticular a estrutura necessária à respectiva efetivação (SARLET, 2007, p. 125.). A questão de a proteção dos fins implicar, também, a proteção aos meios indispensáveis para a respectiva concreção veio, ainda, a ser apreciada neste precedente concernente ao serviço da assistência jurídica integral e gratuita a ser prestado pelo Estado, cuja tese está bem resumida na ementa que segue:

O descumprimento, pelo Poder Público, do dever que lhe impõe o art. 134 da Constituição da República traduz grave omissão que frustra, injustamente, o direito dos necessitados à plena orientação jurídica e à integral assistência judiciária e que culmina, em razão desse inconstitucional inadimplemento, por transformar os direitos e as liberdades fundamentais em proclamações inúteis, convertendo-os em expectativas vãs. - É que de nada valerão os direitos e de nenhum significado revestir-se-ão as liberdades, se os fundamentos em que eles se apoiam além de desrespeitados pelo Poder Público ou transgredidos por particulares - também deixarem de contar com o suporte e o apoio de um aparato institucional, como aquele proporcionado pela Defensoria Pública, cuja função precípua, por efeito de sua própria vocação constitucional (CF, art. 134), consiste em dar efetividade e expressão concreta, inclusive mediante acesso do lesado à jurisdição do Estado, a esses mesmos direitos, quando titularizados por pessoas necessitadas, que são as reais destinatárias tanto da norma inscrita no art. $5^{\circ}$, inciso LXXIV, quanto do preceito consubstanciado no art. 134, ambos da Constituição da República. - O desrespeito à Constituição tanto pode ocorrer mediante ação estatal quanto mediante inércia governamental. A situação de inconstitucionalidade pode derivar de um comportamento ativo do Poder Público, que age ou edita normas em desacordo com o que dispõe a Constituição, ofendendo-lhe, assim, os preceitos e os princípios que nela se acham consignados. Essa conduta estatal, que importa em um "facere" (atuação positiva), gera a inconstitucionalidade por ação. - Se o Estado deixar de adotar as medidas necessárias à realização concreta dos preceitos da Constituição, em ordem a torná-los efetivos, operantes e exequíveis, abstendo-se, em consequência, de cumprir o dever de prestação que a Constituição lhe impôs, incidirá em violação negativa do texto constitucional. Desse "non facere" ou "non praestare" resultará a inconstitucionalidade por omissão, que pode ser total, quando é nenhuma a providência adotada, ou parcial, quando é insuficiente a medida efetivada pelo Poder Público. Precedentes (ADI 1.458-MC/DF, Rel. Min. CELSO DE MELLO, v.g.). Doutrina (BRASIL. Supremo Tribunal Federal. 2014.).

Entretanto, nem tão segura é tal compreensão. Primeiro, pela própria caracterização de qualquer direito subjetivo como dotado de fundamentalidade suficiente para se considerar abrangido na proteção do inciso IV do $\S 4^{\circ}$ do artigo 60 da Constituição de 1988, que, em última análise, traduz restrição, como todos os demais incisos do aludido parágrafo, à própria atividade do Poder Legislativo (BRASIL. Supremo Tribunal Federal. 2006; idem. 2005.). Segundo, em função da própria visão de mundo dos julgadores (BARROSO, 2012, p. 394-5.) - que, em 
absoluto, se pode explicar por uma eventual coincidência de visões entre estes e a autoridade que os nomeou, como poderia parecer a uma mirada superficial -, em regra, fruto de uma formação eminentemente privatística, refratária, em princípio, à atuação do Estado, consoante se pode verificar na orientação adotada em casos como os relacionados a privatizações de empresas estatais (BRASIL. Supremo Tribunal Federal. 2014; idem. 2008; idem. 2008; idem. 2006; idem. 2002.), concessões de serviços públicos (BRASIL. Supremo Tribunal Federal. 2011.), atuação do terceiro setor (BRASIL. Supremo Tribunal Federal. 2015), restrições ambientais (BRASIL. Supremo Tribunal Federal. 2006), perdas salariais decorrentes de medidas anti-inflacionárias (BRASIL. Supremo Tribunal Federal. 2015), a caracterização da irredutibilidade salarial como tendo expressão estritamente nominal, sem força para assegurar a respectiva recomposição diante da desvalorização da moeda (BRASIL. Supremo Tribunal Federal. 1994).

\section{A Emenda Constitucional n. 95, de 2016 - Emenda do "Teto de Gastos" - e os direitos sociais}

Neste sentido é que se vai discutir acerca do que representa a Emenda Constitucional n. 95 , de 13 de dezembro de 2016, que aparece, indubitavelmente, como o passo decisivo para a implementação do Estado Mínimo no Brasil (NUNES FILHO, 2016; FREITAS, 2016, FERREIRA, 2016; CAMARGO, 2016.). Ela acrescenta ao já bastante alargado ato das disposições constitucionais transitórias os artigos 101 até 108, que vão instituir o chamado novo regime fiscal que vai estabelecer o famoso teto das despesas públicas, o novo teto, além daquele que já está previsto na Lei Complementar 101, de 4 de maio de 2000, conhecida popularmente como lei de responsabilidade fiscal. O teto, entretanto, será alvo de algumas exceções e estas estão mencionadas no $\S 6^{\circ}$ do artigo 102, que foi acrescido ao ato das disposições constitucionais transitórias. É no caput deste artigo 102 que são estabelecidos os chamados os limites individualizados para as despesas primarias do Poder Executivo, Senado, Supremo Tribunal Federal, Ministério Público, Defensoria Pública. Estes limites equivalem para o exercício de 2017 a despesa primaria paga no exercício de 2016, corrigida de sete virgula dois por cento. Os exercícios posteriores no valor do limite do referente ao do exercício exatamente anterior, ou seja, aquele que está previsto no ano de 2017 em 2018, ao que está previsto em 2018 em 2019 e assim sucessivamente, corrigido pela variação do IPCA ou outro índice a ele equivalente. E há exceções a estes limites e estão postas aqui, referentes aos Royalties de petróleo, ao Fundo de Participação dos Estados e Municípios na arrecadação das entidades maiores, a vinculação 
de impostos com educação e saúde, a assistência financeira ao Distrito Federal, as complementações da União dos valores mínimos por aluno no ensino público municipal e estadual no âmbito do Fundo de Desenvolvimento do Ensino Brasileiro - FUNDEB, previstas no artigo 60 das Disposições Constitucionais Transitórias, os denominados créditos extraordinários as despesas decorrentes da justiça eleitoral e despesas com aumento de capital com as estatais e também as questões relacionadas com a dívida pública. O que está sujeito ao teto? Todo o restante. As disposições que excepcionam têm que ser interpretadas nos seus termos estritos, isto é velha regra de hermenêutica, para utilizar a expressão de Carlos Maximiliano e de outros autores que utilizam a palavra regra, na acepção cartesiana. Ou para utilizar uma linguagem de Humberto Ávila, “postulado hermenêutico", e são utilizadas ambas as terminologias justamente para facilitar a compreensão. A grande questão na realidade vai entrar tanto no que tange as interdições postas em relação ao aumento de despesas elencadas no artigo 104, como concessão de vantagens, aumento, reajuste adequação de renumeração de servidores, criação de cargos, muitas delas já previstas na Lei de Responsabilidade Fiscal. O artigo 104 recalcitra em muitos aspectos: alteração de estrutura de carreira, aumento de remunerações, realização de concurso público salvo reposições, isto acaba tendo uma influencia fortíssima em relação à própria universidade, por exemplo: o aumento do numero de alunos acarreta uma necessidade de coadunar com o pessoal disponível. Na faculdade de direito, há turmas de oitenta alunos por sala. Criação e elaboração de auxílios, bônus, abonos, criação de despesas obrigatórias, criação e expansão de programas, concessão de benefício de natureza tributária. Com relação a esses dispositivos em si mesmos, há uma certa polêmica quanto a agredirem determinadas cláusulas: separação de poderes, eleições periódicas, federalismo. Há pronunciamentos por parte de membros da consultoria legislativa do Senado tanto neste sentido (VIEIRA JÚNIOR, 2016) como em sentido contrário (FREITAS, 2016). Com relação ao tema e a estes dispositivos, particularmente, não se vislumbra inconstitucionalidade. Percebe-se eventualmente a criação de maiores dificuldades no que tange a própria continuidade de alguns serviços públicos: isto é um fato. Mas inconstitucionalidade, não. Por exemplo, o teto pode aplicar-se a vinculação da ciência e tecnologia porque ela não esta excepcionada. Ao que não está excepcionado aplica-se o teto. Agora, educação, saúde, essas estão excepcionadas. Muito bem, agora embora excepcionadas educação e saúde nós vamos ao artigo 105. E é aqui que se pode identificar alguma invalidade da Emenda, é neste artigo. Nos outros, bem perceptível a criação de uma dificuldade maior dos serviços públicos, provavelmente até mesmo uma imposição que muitos desses serviços sejam terceirizados, mas não inconstitucionalidade. Mas aqui está presente: "Na vigência do novo regime fiscal, as habilitações mínimas em ações de 
serviços públicos de saúde e manutenção desenvolvimento ensino equivaleram no exercício de dois mil e dezessete as aplicações mínimas calculadas nos termos do inciso I do $\S 2^{\circ}$ segundo do artigo 198 e do caput do 211 da Constituição Federal, e nos exercícios posteriores aos valores calculados para aplicações mínimas do exercício imediatamente anterior corrigidos na forma estabelecida pelo inciso II do $\S 1^{\circ}$ do artigo 102 deste Ato das Disposições Constitucionais Transitórias". Recordemos: para que serve o orçamento? O orçamento serve para dizer o que se espera arrecadar e o que se está autorizado a gastar. É esta matéria que deve constar no orçamento. Porque isto? Assim se faz a constituição ao exigir que o orçamento só contenha esta matéria. Esta e nenhuma outra. Na República Velha - período de 1889 a 1930, em que vigorou a Constituição de 1891 - era muito comum que na lei orçamentária se enclaustrasse matérias das mais diversas naturezas, os chamados riders, ou, no jargão financista brasileiro, "caudas orçamentárias": Rui Barbosa chamava os orçamentos federal, estaduais e municipais de "rabilongos", isto é, tinham uma "cauda" muito grande. Três anos após a morte de Rui, isto é, em 1926, veio uma emenda a Constituição de 1891 que passou a restringir a matéria orçamentária. Esta emenda restringiu o habeas corpus, modificou muitas coisas mais, entre outras, a matéria orçamentária. Desde então as Constituições brasileiras exigem que a lei orçamentária somente trate de autorização de despesa e estimativa da receita. A receita dos impostos que se pretende arrecadar normalmente vai ser distribuída pelas rubricas orçamentárias do modo que o legislador desejar, avaliando a conveniência e oportunidade de destinar tanto do que se obtenha dos contribuintes, e é exatamente por isso que a Constituição proíbe, no inciso IV do seu artigo 167, a vinculação arrecadação de impostos a fundo ou determinada rubrica. Esta proibição tem exceções, e quais são? Ciência e tecnologia, saúde, educação e divida pública (Constituição Federal, artigos 198, 212, 218), tais são as rubricas que sofrem vinculação. Este montante varia conforme a arrecadação. Esta expressão é algébrica, em linha de princípio. Porém, essa expressão algébrica pelo artigo 105 do Ato das Disposições Constitucionais Transitórias, em relação a educação e saúde, torna-se uma expressão aritmética. Por quê? Porque vai ser aquele percentual da arrecadação sobre arrecadação de 2016. Só que ele vai ficar fixo a partir de 2017; será um valor fixo. Enquanto a arrecadação vai subindo aquele valor desaparece. O percentual, em si mesmo, sobre o montante, vai diminuindo. Em diminuindo o percentual da educação e da saúde, o espectro de possíveis usuários da educação pública e da saúde pública se reduz. Qual é a importância disto? Toda. Porque o artigo $6^{\circ}$ da Constituição Federal elenca a educação e a saúde como direitos sociais e eles não são tratados como direito diante do particular, porque a educação e saúde podem ser ofertadas pelo particular. E por quê? Porque quando elas são ofertadas pelo particular elas são um serviço que 
se pode fruir por um contato que se celebra, que se pode celebrar livremente, que se tem liberdade pra não celebrar, ao contrário da educação e saúde públicas que têm de ser ofertadas; o Poder Público não pode não querer ofertar. Ele é obrigado a ofertar. neste caso, presente a redução drástica justamente da viabilização financeira destes direitos, e neste sentido está coberto de razão o Professor Fernando Facury Scaff (SCAFF, 2016) da Universidade Federal do Pará, autor de uma obra clássica sobre a responsabilidade do estado intervencionista, e que está bem longe de poder ser considerado um estatizante. Porque se esta falando de inconstitucionalidade? Porque o inciso quarto do parágrafo quarto do artigo sessenta fala que não será objeto se quer de deliberação a proposta de emenda tendente a abolir direitos e garantias individuais. E a restrição ao máximo do universo de atendidos é tendente sim a abolir direitos e garantias individuais. Mas não se refere aos direitos sociais? Mas os direitos sociais podem ser fruídos individualmente. E até mesmo juristas conhecidos pelo seu compromisso ideológico visceral com o liberalismo econômico, como é o caso do professor Manuel Gonçalves Ferreira Filho, como é o caso do professor Raul Machado Horta, já mencionados nesta comunicação, consideram abrangidos pelo inciso IV do $\S 4^{\circ}$ do artigo 60 da Constituição Federal, dos direitos sociais. Neste particular e somente neste particular é visualizada inconstitucionalidade. Por quê? Porque, ao cabo, termina-se por restringir o acesso da educação em todos os níveis inclusive o superior e a saúde. A questão é saber se hoje se a educação e a saúde tem que deixar de ser direito e converter-se em commodities a tese, só que para isso temse de superar a interdição posta no $\S 4^{\circ}$ do artigo 60 . Tanto que quando ministro Luis Roberto Barroso negou a liminar em mandado de segurança para travar a PEC então 241, e voltou a negar a liminar para travar a discussão da PEC 55 ele conseguiu superar bem a questão do federalismo, a questão das eleições periódicas do voto direto e secreto e a questão da separação de poderes essas três ele conseguiu superar. Mas quando ele viu a tendência de abolir os direitos e garantias ele não conseguiu trazer fundamento sustentável. Assim, se há alguma inconstitucionalidade na Emenda Constitucional 95, de 2016, que de tal proposta resultou, é esta. A questão é realmente saber se considera a oferta do ensino inclusive no âmbito universitário um direito ou uma commodity ou um bem a ser adquirido mercê da celebração de contratos. O mesmo se pode dizer em relação à saúde. Deverá ela ser tida como um direito ou uma commodity?

\section{Conclusão}

Sob o ponto de vista prático, a jurisprudência do Supremo Tribunal Federal tem possibilidades para o pronunciamento da inconstitucionalidade ou não. A declaração da 
invalidade da Emenda nos pontos em que realmente agredidas cláusulas pétreas preservaria a orientação originária da Constituição de 1988 e se poria como um contraponto a uma possível onipotência dos titulares do poder econômico privado, e não entraria em contrariedade com a tradição jurídica brasileira, como se pode ver dos conceitos emitidos por Rui Barbosa, logo após a I Guerra Mundial, deixando claro que a política econômica, como qualquer outra das manifestações da política em um Estado de Direito não constitui a concessão que se faz ao arbítrio. Entretanto, a ideia de converter a preservação das finanças públicas em um fim em si tem um apelo muito forte, parece estar informada apenas pela objetividade do cálculo matemático, e por esta ideia em discussão, no Brasil, hoje em dia, é palmilhar a estrada do Calvário.

\section{Referências bibliográficas}

ARISTÓTELES. Da interpretação. In: ARISTÓTELES. Organon. Trad. Edson Bini. Bauru: Edipro, 2010, pp. 81-110.

AZEVEDO, Plauto Faraco de. Justiça distributiva e aplicação do Direito. Porto Alegre: Sergio Antonio Fabris, 1983.

BARACHO, José Alfredo de Oliveira. Regimes políticos. São Paulo: Resenha Universitária, 1977.

BARBOSA, Rui. A questão social e política no Brasil. In: BARBOSA, Rui. Obras completas - campanha presidencial - 1919. Rio de Janeiro: MEC, 1956, v. 46, t. 1, pp. 63-130.

BARROSO, Luís Roberto. O controle de constitucionalidade no Direito brasileiro. São Paulo: Saraiva, 2012.

BERLE, Adolf A. Poder sin propiedad. Trad. Juan Carlos Pellegrini. Buenos Aires: Tipografia Editora Argentina, 1961.

BOBBIO, Norberto. Ensaios escolhidos. Trad. Sérgio Bath. São Paulo: C. H. Cardim, s/d. 
CAMARGO, Ricardo Antonio Lucas. Regime jurídico geral e especial da atividade econômica no Brasil. Porto Alegre: Sergio Antonio Fabris, 2015.

CAMARGO, Ricardo Antonio Lucas \& DARCIE, Jonathan Doering. Aula pública sobre aspectos jurídicos da PEC 55 ministrada no Instituto de Informática da Universidade Federal do Rio Grande do Sul, em 30 nov 2016. In: https:/drive.google.com/drive/u/1/ folders/0B0rSNJbvwFj_bElZa3V4ZzdSN1U, acessado em 10 dez 2016.

CARNELUTTI, Francesco. Teoria geral do Direito. Trad. Antonio Carlos Ferreira. São Paulo: Lejus, 1999.

CARAVALHOSA, Modesto de Souza Barros. Comentários à lei das sociedades anônimas. São Paulo: Saraiva, 2013, v. 1.

COMPARATO, Fábio Konder. Aspectos jurídicos da macroempresa. São Paulo: Revista dos Tribunais, 1970.

FERRARI, Regina Maria Nery Macedo. Direito Constitucional. São Paulo: Revista dos Tribunais, 2011.

FERREIRA FILHO, Manoel Gonçalves. Curso de Direito Constitucional. São Paulo: Saraiva, 2015.

FERREIRA, Pedro Fernando Nery. Reformas gêmeas: o Novo Regime Fiscal e a Reforma da Previdência. Brasília: Núcleo de Estudos e Pesquisas/CONLEG/Senado, Novembro/2016 (Boletim Legislativo $\mathrm{n}^{\mathrm{o}}$ 52, de 2016). Disponível em: www.senado.leg.br/estudos. Acesso em $1^{\circ}$ de novembro de 2016.

FOUCAULT, Michel. As palavras e as coisas. Trad. Salma Tannus Muchail. São Paulo: Martins Fontes, 1992.

FREITAS, Paulo Springer de. A PEC n ${ }^{0}$ 55, de 2016, e seus Impactos sobre a Federação, Gastos Primários e Endividamento Público. Brasília: Núcleo de Estudos e 
Pesquisas/CONLEG/Senado, novembro/2016 (Boletim Legislativo no 57, de 2016).

Disponível em: www.senado.leg.br/estudos. Acesso em11 de novembro de 2016.

FREITAS, Paulo Springer; MENDES, Francisco Schertel Ferreira. Comentários sobre a PEC do Teto dos Gastos Públicos aprovada na Câmara dos Deputados: necessidade e constitucionalidade da medida. Brasília: Núcleo de Estudos e Pesquisas/CONLEG/Senado, novembro/ 2016 (Boletim Legislativo $\mathrm{n}^{\circ}$ 55, de 2016). Disponível em: www.senado.leg.br/estudos. Acesso em 7 de novembro de 2016.

HAYEK, Friedrich August von. Direito, legislação e liberdade - a ordem política de um povo livre. Trad. Henry Maksoud. São Paulo: Visão, 1985.

HORTA, Raul Machado. Direito Constitucional. Belo Horizonte: Del Rey, 2010.

GRAU, Eros Roberto. A ordem econômica na Constituição de 1988 - interpretação e crítica. São Paulo: Malheiros, 2010.

HUME, David. Escritos sobre economia. Trad. Sara Albieri. In: CAMPOS, Roberto de Oliveira \& KUNTZ, Rolf (org.). Os economistas - Petty - Hume - Quesnay. São Paulo: Abril Cultural, 1982, pp. 185-244.

JELLINEK, Georg. Teoría general del Estado. Trad. Fernando de los Ríos Urruti. Buenos Aires: Albatros, 1943.

JORNAL DO BRASIL. TST tem “má vontade” com empresas, afirma Gilmar Mendes. http://www.jb.com.br/pais/noticias/2016/10/21/tst-tem-ma-vontade-com-empresas-afirmagilmar-mendes/, acessado em 21 out 2016.

MALTHUS, Thomas Robert. Ensaio sobre a população. Trad. Antonio Alves Cury. In: GALVEAS, Ernane (org.). Os economistas - Malthus. São Paulo: Nova Cultural, 1996, pp. 233-378.

MILL, John Stuart. De la libertad - del gobierno representativo - esclavitud feminina. Trad. Marta C. C. Iturbe. Madrid: Tecnos, 1965. 
NUNES FILHO, Petrônio Portella. A PEC do Teto dos Gastos Públicos é Necessária? Estudo do Endividamento Federal após o Plano Real. Brasília: Núcleo de Estudos e Pesquisas/ CONLEG/Senado, Novembro/2016 (Texto para Discussão nº 217). Disponível em: www.senado.leg.br/estudos, . Acesso em 7 de novembro de 2016.

PEZZELLA, Maria Cristina Cereser \& BUBLITZ, Michelle Dias. Pessoa como sujeito de direitos na sociedade da informação: um olhar sob a perspectiva do trabalho e do empreendedorismo. Revista Sequência. Florianópolis, n. 68, p. 239-260, jun 2014.

PRUNES, José Luiz Ferreira. Trabalho terceirizado e composição industrial. Curitiba: Juruá, 1999.

RICARDO, David. Princípios de economia política e do imposto. Trad. C. Machado da Fonseca. Rio de Janeiro: Atena, 1937.

SARLET, Ingo Wolfgang. Dignidade da pessoa humana e direitos fundamentais na Constituição Federal de 1988. Porto Alegre: Livraria do Advogado, 2007.

SCAFF, Fernando Facury. PEC do Teto de Gastos também deveria limitar arrecadação de impostos. http://www.conjur.com.br/2016-nov-01/contas-vista-pec-teto-gastos-deverialimitar-arrecadacao-impostos. Acessado em $1^{\circ}$ nov 2016.

SILVA, José Afonso da. Curso de Direito Constitucional positivo. São Paulo: Malheiros, 2012.

SMITH, Adam. A riqueza das nações - uma investigação sobre a sua natureza e as suas causas. Trad. Luís João Baraúna. São Paulo: Nova Cultural, 1996, v. 1.

SMITH, Adam. Teoria dos sentimentos morais. Trad. Lya Luft. São Paulo: Martins Fontes, 2002.

SOUZA, JÚNIOR, Cezar Saldanha de. Consenso e democracia constitucional. Porto Alegre: Sagra Luzzatto, 2002. 
SOUZA, Washington Peluso Albino de. Primeiras linhas de Direito Econômico. $6^{\text {a }}$ ed. São Paulo: LTr, 2005.

SOUZA, Washington Peluso Albino de. Teoria da Constituição Econômica. Belo Horizonte: Del Rey, 2002.

THEODORO, Mário Lisboa. A PEC 241 é a única saída para a Crise Fiscal? Argumentos a favor de uma alternativa socialmente mais justa e economicamente mais eficaz. Brasília: Núcleo de Estudos e Pesquisas/CONLEG/Senado, novembro/ 2016 (Boletim Legislativo $n^{\circ}$ 56, de 2016). Disponível em: www.senado.leg.br/estudos . Acesso em 11 de novembro de 2016.

VIEIRA JÚNIOR, Ronaldo Jorge Araújo. As inconstitucionalidades do "Novo Regime Fiscal” Instituído pela PEC n ${ }^{0}$ 55, de 2016 (PEC no 241, de 2016, na Câmara dos Deputados). Brasília: Núcleo de Estudos e Pesquisas/CONLEG/Senado, novembro/2016 (Boletim Legislativo $\mathrm{n}^{\circ}$ 53, de 2016). Disponível em: www.senado.leg.br/estudos. Acesso em $1^{\circ}$ de novembro de 2016.

WEBER, Max. Economía y sociedad. Trad. Salvador M. Echavarría et allii. México: Fondo de Cultura Económica, 1992. 


\title{
OS DIREITOS SOCIAIS FUNDAMENTAIS NO MARCO DO ESTADO \\ DEMOCRÁTICO DE DIREITO: A DIGNIDADE HUMANA E O "MÍNIMO EXISTENCIAL", FUNDAMENTOS DOS DIREITOS HUMANOS FUNDAMENTAIS
}

\author{
Rodrigo Garcia Schwartz \\ Universidade do Oeste de Santa Catarina \\ Juliana de Oliveira \\ Universidade do Oeste de Santa Catarina
}

\begin{abstract}
Resumo
O presente artigo tem por escopo colaborar para a percepção de que os direitos sociais não são apenas plenamente compatíveis com a democracia, mas constituem um componente essencial dos valores fundamentais da mesma, ancorados na dignidade humana. O problema de pesquisa é identificar os fundamentos dos proclamados direitos humanos fundamentais, especialmente os sociais, relacionando, portanto, as questões da dignidade humana e do mínimo existencial, como fundamentos dos direitos humanos fundamentais, à concretização dos direitos sociais no marco do Estado democrático de direito. O procedimento investigativo é descritivo-explicativo do tipo documental-bibliográfico.
\end{abstract}

Palavras-chaves: dignidade humana, direitos fundamentais, direitos humanos, direitos sociais, mínimo existencial.

\section{Abstract/Resumen/Résumé}

This article aims to contribute to the perception that social rights are not only fully compatible with democracy but are an essential component of the fundamental values of democracy, anchored in human dignity. The research problem is to identify the foundations of the proclaimed fundamental human rights, especially the social ones, relating, therefore, the issues of human dignity and the existential minimum, as foundations of fundamental human rights, to the realization of social rights within the democratic rule of law. The investigative procedure is descriptive-explanatory of the documentary-bibliographic type.

Keywords/Palabras-claves/Mots-clés: fundamental rigths, human dignity, human rigths, social rights, minimum existential. 


\section{Introdução}

$\mathrm{Na}$ atualidade, são os direitos humanos fundamentais - ou, melhor, o respeito efetivo aos direitos humanos fundamentais - o principal referente para avaliar a legitimidade de um ordenamento jurídico-político, internamente ou perante a comunidade internacional. Assim, no âmbito do constitucionalismo social contemporâneo, o tratamento especial/privilegiado concedido aos direitos humanos, entre eles os direitos sociais, justifica-se a partir de uma profunda afinidade axiológica e normativa entre o direito internacional contemporâneo, que, a partir da Carta das Nações Unidas e da Declaração Universal dos Direitos Humanos, confere especial hierarquia para os direitos humanos, e o direito interno de cada país membro da ONU, que confere, de forma similar, com maior ou menor ênfase, uma especial hierarquia para esses direitos, considerados fundamentais.

É natural que as constituições contemporâneas, ao menos no Ocidente, tendam a realçar essa profunda afinidade, conferindo um status especial para os instrumentos internacionais de direitos humanos, inclusive submetendo-se à jurisdição de tribunais internacionais. No caso brasileiro, v.g., a Constituição de 1988 dispõe que "Os direitos e garantias expressos nesta Constituição não excluem outros decorrentes do regime e dos princípios por ela adotados, ou dos tratados internacionais em que a República Federativa do Brasil seja parte" e que "O Brasil se submete à jurisdição de Tribunal Penal Internacional a cuja criação tenha manifestado adesão" (art. 5. ${ }^{\circ}, \S \S 2 .^{\circ}$ e $4 .^{\circ}$, este último incluído pela Emenda Constitucional n. ${ }^{\circ}$ 45/2004).

Nesse contexto, o presente artigo pretende analisar a fundamentação argumentativa da presumida validade universal dos direitos humanos, para todos os homens, e a consequente eleição, pela via constitucional, de determinados direitos como fundamentais, a partir de uma ideia axiologicamente adequada de dignidade humana, compreendida como o elemento central para a construção de um fundamento, independentemente da forma jurídica que os veiculem dogmaticamente, para os proclamados direitos humanos fundamentais, especialmente os sociais, relacionando, portanto, as questões da dignidade humana e do mínimo existencial, como fundamentos dos direitos humanos fundamentais, aos direitos sociais no marco do Estado democrático de direito e do pacto social instituinte consubstanciado na Constituição.

Trata-se, portanto, de uma revisão do tipo documental-bibliográfica, cujo escopo é auxiliar na compreensão de que a continuidade axiológica e estrutural de todos os direitos humanos fundamentais põe em evidência que os direitos sociais não são apenas plenamente compatíveis com a democracia, mas constituem um componente essencial dos valores 
fundamentais da mesma, ancorados na dignidade humana, não havendo, portanto, razões legítimas para a postergação dos direitos sociais. Ao contrário, as exigências morais que estes incorporam são tão fortes que têm a legítima pretensão de serem reconhecidos como direitos subjetivos diante dos poderes públicos e privados, sobretudo frente às administrações públicas, pois o que faz de um direito um direito fundamental são as razões especialmente fortes para que esse direito seja juridicamente protegido com especial zelo pelo próprio instrumento que consubstancia o pacto social instituinte - a Constituição.

\section{Os direitos sociais fundamentais no marco do Estado democrático de direito}

Nos ordenamentos atuais, o reconhecimento de um direito como fundamental, por si só, inclusive no âmbito dos direitos sociais, implica a atribuição ao mesmo de um conteúdo mínimo e, com isso, a imposição de certas obrigações elementares para os poderes públicos, especialmente obrigações de não discriminação, de não regressividade e de progressividade. Isso não obsta, por certo, que o alcance concreto de determinados direitos dependa do que os próprios ordenamentos vierem a estipular. Há constituições, como a brasileira de 1988, que desenvolvem de maneira bastante minuciosa o conteúdo dos direitos sociais; outras, somente oferecem regulações mínimas dos direitos sociais, ou relegam esses direitos ao âmbito dos direitos meramente implícitos. Há constituições que estipulam, com detalhes, as obrigações que a consagração de um direito comporta para os poderes públicos e mesmos para os atores privados, enquanto outras apenas fazem menção a essas obrigações.

Em um plano axiológico, o que caracteriza um direito como fundamental é, sobretudo, a sua pretensão de tutela de interesses ou necessidades básicas, ligadas ao princípio da igualdade real. É o caráter generalizável desses interesses, a todas as pessoas, em síntese, que converte em inalienável e indisponível um direito, de forma que direitos fundamentais, direitos humanos e direitos das pessoas têm, nessa perspectiva, significados similares. Ou seja, a ideia de direito fundamental, em um plano axiológico, concerne às prerrogativas e às instituições que o ordenamento positivo concretiza em garantia de uma convivência digna, livre e igual de todas as pessoas. Sua fundamentalidade decorre do fato de que, sem ele, a pessoa não se realiza, não convive e, em situações mais radicais, sequer sobrevive: são direitos imprescindíveis para a vida digna e, por isso, exigíveis em nome de todos e para todos os seres humanos.

Segundo um ponto de vista dogmático, contudo, a situação apresenta-se um pouco mais complexa. Em linhas gerais, temos que, habitualmente, os direitos ditos fundamentais são aqueles a que se atribui maior relevância dentro de um determinado ordenamento jurídico, 
relevância que pode ser medida a partir da inclusão desse direito em normas de maior valor no âmbito do ordenamento interno, como as constitucionais, ou mesmo em tratados e convenções internacionais (FREIRE, 1997).

É possível, assim, e mesmo desejável, que determinados direitos, que poderiam ser considerados fundamentais desde um ponto de vista axiológico, também o sejam a partir de uma perspectiva dogmática. Mas nem sempre há essa conexão, de forma que os ordenamentos podem incorporar, em si, como fundamentais, interesses e necessidades discriminatórios ou excludentes, sempre criticáveis do ponto de vista axiológico ${ }^{1}$.

De qualquer forma, não são, de fato, as garantias concretas de determinado direito que permitem categorizá-lo como fundamental ou não. Ao contrário, é precisamente a inclusão de um direito, no ordenamento positivo, como fundamental que obriga os operadores jurídicos a maximizarem os mecanismos necessários à sua garantia e proteção. Portanto, se a partir de uma perspectiva axiológica podemos dizer que há certa equivalência entre as expressões "direitos fundamentais", "direitos humanos" e "direitos das pessoas", a partir de uma perspectiva dogmática podemos dizer que há certa equivalência entre as expressões "direitos fundamentais" e "direitos constitucionais".

Dessa forma, a eventual ausência de garantias, legislativas ou jurisdicionais, para um direito constitucional, seja ele de dimensão civil, política ou social, não leva à conclusão de não se tratar de um direito fundamental, mas, ao contrário, demonstra a falta de cumprimento, ou o cumprimento insuficiente, do mandado implícito de atuação contido na norma, por parte dos operadores políticos e jurídicos: não é, nesse caso, o direito que não é fundamental, mas o poder político é que está a incorrer em uma atuação desvirtuada ou omissa, que deslegitima essa atuação (FERRAJOLI et al., 2001).

No plano dos direitos sociais, se a inserção, no texto constitucional, indica o caráter fundamental de um direito, isso não é, todavia, um requisito absolutamente imprescindível, dado o princípio da indivisibilidade e interdependência dos direitos, pois qualquer Constituição que inclua o princípio da igualdade em matéria de direitos civis e políticos básicos estaria portando, no fundo, um mandado de generalização que obrigaria à inclusão, ao menos de forma indireta, dos direitos sociais a eles vinculados. Isso ocorre, atualmente, em diversos ordenamentos que não reconhecem, explicitamente, os direitos sociais, ou não outorgam, de

\footnotetext{
${ }^{1}$ Assim, v.g., a Constituição dos Estados Unidos consagra, na sua Segunda Emenda, como fundamental, o direito ao porte de armas - "(...) the right of people to keep and bear arms shall not be infringed" -, enquanto o Tratado Constitucional Europeu (2004) estabelece uma clara prioridade para as liberdades de mercado sobre os direitos sociais.
} 
forma expressa, a esses direitos o status de direitos fundamentais. Assim, v.g., nesses ordenamentos, o direito à moradia digna tem sido deduzido a partir de outros direitos, como o da inviolabilidade de domicílio, à intimidade ou à vida privada e familiar² .

Nesse contexto, nenhum direito constitucional pode ter a sua exigibilidade condicionada ao seu desenvolvimento legislativo, tampouco o legislador dispõe de uma margem discricionária quase ilimitada para proceder ou não a esse desenvolvimento. Todos os direitos, e não apenas os direitos sociais, mas também os direitos civis e políticos - de participação -, são direitos de configuração legislativa, no sentido de que, para a sua vigência (eficácia) plena, é imprescindível - de uma ou de outra forma - a intervenção legislativa. A lei, tanto pela legitimidade formal dos órgãos de que provém, quanto pelo seu alcance potencialmente generalizável, é uma fonte privilegiada de produção jurídica nos ordenamentos modernos e constitui uma garantia primária da satisfação de qualquer direito (EIDE, 1995).

Todos os direitos fundamentais - civis, políticos, sociais - exigem prestações legislativas, que podem, é claro, ter diferentes alcances. A maior ou menor regulação, por certo, poderá reforçar ou debilitar as possibilidades de exigibilidade judicial dos direitos em questão, mas não impede, por si só, que esses direitos tenham, ao menos, um conteúdo mínimo indisponível aos poderes de turno e suscetível, por isso mesmo, de algum tipo de tutela jurisdicional, mesmo à falta de regulação legislativa ${ }^{3}$.

O que sustentamos é que o reconhecimento constitucional dos direitos sociais, por si só, determina, em qualquer circunstância, e mesmo em tempos de crises econômicas, um núcleo indisponível para os poderes de turno, razão pela qual não se pode deixar de reconhecê-los e, assim, de assegurá-los a todas as pessoas, sobretudo para aquelas que se encontram em posição mais vulnerável (PISARELLO, 2007).

Em síntese, ou todos os direitos, civis, políticos e sociais, são, estruturalmente ou por razões de conveniência política, direitos de livre configuração legislativa, que ficam com a sua efetividade vinculada à discricionariedade dos poderes de turno, ou são, como afirmamos, todos, direitos cujos limites, positivos ou negativos, são indisponíveis aos poderes de turno, inclusive às maiorias legislativas ou aos órgãos jurisdicionais. Assumimos, assim, o ideal normativo da democracia constitucional, ou de uma democracia em que a satisfação ou não de

\footnotetext{
${ }^{2}$ No caso López Ostra contra España (1994), o Tribunal Europeu de Direitos Humanos considerou que a ausência de controle dos poderes públicos sobre uma indústria poluente que afetava a saúde e a segurança das pessoas que viviam nas suas imediações constituía uma violação do direito à vida privada e familiar. No caso, estão envolvidos direitos ao meio ambiente, à saúde e à moradia (direitos sociais), de forma inter-relacionada.

${ }^{3}$ No caso brasileiro, a Constituição de 1988 estabelece que "As normas definidoras dos direitos e garantias fundamentais têm aplicação imediata" (art. $\left.5^{\circ}, \S 1 .^{\circ}\right)$.
} 
um direito a que se vincula a segurança material e a autonomia da pessoa não esteja alienada à discricionariedade de nenhum poder (SADEK, 2001).

Nesse contexto, a concepção contemporânea de Estado, categoria estruturante do pensamento da modernidade ocidental (CANOTILHO, 2002), consubstanciada na moderna fórmula do "Estado democrático de direito", pressupõe uma ordem constitucional democrática e socializante que, por sua vez, como forma de racionalização e de generalização do político e do princípio democrático, estrutura-se a partir de uma articulação sinérgica entre o direito e o poder, na qual o direito constitui o poder político e vice-versa (HABERMAS, 2005), articulação que, por um lado, limita o poder do Estado pelo direito, e, por outro lado, legitima esse mesmo poder (BRITO, 2001).

É, assim, a Constituição ${ }^{4}$, criadora e ordenadora de uma comunidade jurídica e política, que contém, como regra geral, as normas jurídicas que delimitam os órgãos supremos do Estado, estabelecendo a forma de criá-los, as suas relações recíprocas e as suas áreas de influência, além da posição do indivíduo em relação ao poder estatal (JELLINEK, 1921), mas que também assume certos cânones, paradigmas para a configuração do presente e do futuro de uma sociedade, dotando-os, sobretudo no âmbito das garantias e dos direitos chamados fundamentais, de força verdadeiramente vinculante para todo o ordenamento jurídico (HESSE, 1995), que institucionaliza e, em consequência, limita e legitima o exercício do poder estatal e, em última análise, a própria existência do Estado ${ }^{5}$.

Esses, os direitos fundamentais, constituem a razão de ser do Estado de direito, sua finalidade mais radical, o objetivo e critério que dá sentido aos mecanismos jurídicos e políticos que compõem o Estado. A democracia não se limita à participação em decisões, alcançando, também, a participação em resultados, ou seja, em direitos, liberdades, atingimento de expectativas e suprimento de necessidades vitais. O Estado de direito, nessa sua empírica e também racional vinculação e inter-relação com a democracia, converte em sistema de legalidade tal critério de legitimidade; em concreto, institucionaliza de uma forma ou de outra essa participação em resultados, ou seja, garante, protege e realiza os direitos fundamentais.

Portanto, mais do que um simples documento cartular no qual estão delineadas as formas de conquista e de exercício do poder e descritos os direitos e as garantias fundamentais

\footnotetext{
${ }^{4}$ É no movimento do constitucionalismo que se articula a ideia de Constituição como um produto da razão, na esteira do racionalismo iluminista que funda, no âmbito da teoria do Estado, a ideia de um estatuto (Constituição) escrito, criador e ordenador da comunidade política. Nesse sentido, v. Schmidt-Assman (1967) e Matteucci (1976). ${ }^{5}$ Segundo Smende (1968, p. 136 et seq.), o nascimento e a existência do Estado, como unidade política de ação, são condicionados ao êxito do processo de integração estatal, no que se contempla um elemento fundamental de sua essência, a Constituição, o próprio ordenamento jurídico diretor desse processo de integração estatal.
} 
do indivíduo em face do poder do Estado, a Constituição, cumprindo as tarefas fundamentais de formação e de conservação da unidade política do Estado, consubstancia em si não apenas a ordem jurídica fundamental do Estado - ou seja, o estatuto fundamental dos órgãos supremos do Estado -, mas também a ordem jurídica da vida não estatal dentro do território estatal - ou seja, a ordem jurídica fundamental de uma comunidade e a compensação possível entre os diferentes interesses e aspirações individuais e/ou coletivos em conflito no âmbito dessa comunidade -, tarefa arquetípica e concomitante condição de existência do Estado contemporâneo (HESSE, 2009).

Por isso, qualquer que seja o conceito - e a própria justificação - do Estado contemporâneo, este só se pode conceber como Estado constitucional (CANOTILHO, 2002). Mas o Estado constitucional da atualidade não é somente um "Estado de direito", ou seja, não se esgota no tradicional État légal da declaração francesa de 1789, tampouco no Rechsstaat alemão do início do século XIX: o Estado constitucional contemporâneo estrutura-se, sobretudo, como um "Estado democrático de direito" (ou um "Estado constitucional democrático de direito”), ou seja, como uma ordem de domínio constitucional legitimada pelo povo, que articula o direito e o poder político em bases democráticas a partir do princípio da soberania popular, princípio segundo o qual o poder político deriva do poder dos cidadãos ${ }^{6}$.

É nesse contexto, amplamente relacionado com as ideias de contrato social e de vontade geral, ou seja, de um pacto social instituinte, elemento utópico que é, por um lado, revolucionário ao seu tempo, e, por outro lado, fundante de um discurso moderno sobre a democracia, que o poder político emerge contemporaneamente como uma força autorizadora da soberania popular, força que cria um direito legítimo e funda as suas instituições, vinculandoas às razões que as fizeram exsurgir (ARENDT, 1989).

Esse "Estado constitucional democrático de direito" é tributário, ademais, da ideia de democracia econômica, social e cultural, consequência política e lógico-material do próprio princípio democrático (BÖCKENFÖRDE, 1976). Assim, com maior ou menor ênfase, quase todos os Estados democráticos ocidentais integraram ao "núcleo duro" das suas constituições o princípio da solidariedade - ou socialidade -, que se concretiza nos direitos sociais, mas não se esgota neles, espraiando-se sobre todo o ordenamento jurídico (RESTA, 2005). O Estado democrático de direito consiste, nesse contexto, na persecução de justiça social, segurança

\footnotetext{
${ }^{6}$ Cf. Böckenförde (1987, p. 887 et seq.). Na Constituição brasileira de 1988, o princípio da soberania popular está enunciado no parágrafo único do art. 1..: "Todo o poder emana do povo, que o exerce por meio de representantes eleitos ou diretamente, nos termos desta Constituição".
} 
social e assistência social, desvelando-se a solidariedade, a partir disso, como direito e dever social (SCHWARZ, 2011).

Por isso, atualmente, é impossível desvincular a ideia de Estado, como o próprio tema da democracia e do poder político, do exercício da gestão dos interesses públicos e da sua própria demarcação (WARAT, 1994), pois o Estado democrático de direito, ancorado na soberania popular, deve pautar-se pela busca de superação de déficits de inclusão social e participação política, proporcionando novos espaços de interlocução, deliberação e execução, assegurando a todas as pessoas as prestações necessárias e os serviços públicos adequados ao desenvolvimento de suas vidas, contemplados não apenas a partir das liberdades civis tradicionais, mas sobretudo a partir dos direitos econômicos, sociais e culturais garantidos pela ordem constitucional social (LEAL, 2006).

\section{A dignidade humana e o mínimo existencial: fundamentos e pedras de toque dos direitos humanos fundamentais}

A Constituição impõe ao Estado um dever de realizar os direitos fundamentais, sobretudo porque a dignidade humana constitui um valor constitucional supremo ${ }^{7}$, o epicentro de todo o ordenamento jurídico, em torno do qual gravitam todas as demais normas. Os direitos sociais, direitos que sustentam o conceito de mínimo existencial, não podem deixar de ser concretizados sem que se viole profundamente esse valor supremo que é a dignidade humana (BÖCKENFÖRDE, 1987).

A fundamentação argumentativa da presumida validade universal dos direitos humanos, para todos os homens, e a consequente eleição, pela via constitucional, de determinados direitos como fundamentais, tem que poder basear-se em uma ideia axiologicamente adequada de dignidade humana: esta, a dignidade humana, constitui o elemento central para a construção de um fundamento, independentemente da forma jurídica que os veiculem dogmaticamente, para os proclamados direitos humanos fundamentais. Os direitos humanos têm que poder ser positivados axiologicamente como direitos fundamentais do homem; a dignidade humana, fundamento a partir do qual isso acontece, é uma "premissa forte", ou seja, é uma idealização que está presente em todas as positivações, mas que não se perde nelas. Essa tal ideia de dignidade humana tem que constituir um fundamento normativo

\footnotetext{
${ }^{7}$ Segundo a Constituição brasileira de 1988, a “dignidade da pessoa humana” é um dos fundamentos da República (art. 1. ${ }^{\circ}$, inc. III).
} 
universal sólido e irredutível de todas as declarações concretas de direitos humanos e de todas as constituições dos Estados democráticos de direito.

Caberia perguntarmo-nos se temos, de fato, tal concepção de dignidade humana. Sua definição não parece haver sido alcançada, até o momento, senão de forma negativa e indireta, considerando-se, assim, expressão da dignidade humana justamente uma série de direitos e de expectativas materiais cuja violação concreta representaria, concomitantemente, a violação da dignidade humana ${ }^{8}$. A par desse evidente círculo vicioso, essa definição indireta poderia ser enunciada nos seguintes termos gerais - a dignidade humana consiste, basicamente, naquilo que seria violado:

a) se fossem subtraídos, à pessoa, os bens indispensáveis para a vida e/ou as liberdades mínimas;

b) se é imposta à pessoa profunda e duradoura dor física e/ou psíquica evitável, ou se lhe é negado ou reduzido o próprio status de sujeito de direito.

O núcleo central de tal ideia de dignidade humana, como fundamento universal dos catálogos de direitos humanos particularizados culturalmente, requer, ademais, uma variação em torno das formulações do imperativo moral kantiano ${ }^{9}$ : exige-se de qualquer homem que trate a outro da forma como gostaria de ser tratado por este, e não como as circunstâncias conjunturais o indiquem. Os direitos humanos são, portanto, uma questão social e cultural (educacional), e não uma questão meramente política ou econômica.

Assim, a questão dos direitos humanos, e com ela da própria dignidade humana, coloca-se como algo parecido a uma "maratona existencial", de resistência e de afirmação (ZAMBRANO, 2008): incumbe a todos e a cada um de nós, sendo indelegável a terceiros mesmo ao Estado -, sob pena de perda de autonomia, respeito e, mesmo, dignidade. É uma tarefa de todos e de cada um dos cidadãos/administrados, independentemente de sua origem,

\footnotetext{
${ }^{8}$ A formação de um catálogo de direitos humanos está, de fato, associada ao catálogo das chamadas "histórias tristes", ou seja, àquelas experiências coletivas de extremo sofrimento e de exposição do homem a experiências extremamente indignas, sobretudo ao longo do século vinte, pródigo em guerras, ditaduras e genocídios, objeto de sucessivas interpretações morais que constituem a base do chamado "saber moral" negativo (Margalit, 1997, p. 141 et seq.). Para os que dispõem desse saber, é muito clara a exigência de concretizar a proteção dos direitos humanos para evitar-se que essas experiências se repitam. É nesse sentido que Habermas (2003, p. 124) afirma que na maioria dos artigos referentes aos direitos humanos retumba o eco de uma injustiça sofrida que passa a ser negada, por assim dizer, palavra por palavra.

${ }^{9}$ O princípio da dignidade humana desenvolveu-se, sobretudo, a partir dos estudos de Immanuel Kant: foi Kant que, tentando fundamentar um dos imperativos categóricos universais por ele formulados, pôs em evidência o caráter único e finalístico em si mesmo do ser humano: "Age como se a máxima de tua ação devesse tornar-se, por tua vontade, lei universal da natureza" (Kant, 1974, p. 224). Kant afirma, assim, que o homem, e de uma maneira geral todo o ser racional, existe como fim em si mesmo, não só como meio para o uso arbitrário desta ou daquela vontade. Pelo contrário, em todas as suas ações, tanto nas direcionadas a ele mesmo como nas que se dirigem a outros seres racionais, ele (o homem) deve ser "sempre considerado simultaneamente como um fim" (Kant, 1974, p. 229).
} 
de sua condição social ou de suas convicções. Se tal revolução cultural e mental não ocorre, de pouco ou mesmo de nada serve que um Estado-providência provedor de utopias reedite as atitudes de um déspota esclarecido.

Em síntese, àqueles que ainda não aceitam a ideia da dignidade humana como valor palpável, integrado concretamente ao sistema jurídico, por entendê-la como uma formulação demasiadamente abstrata, devendo apenas fornecer, por isso, uma base para a aplicação de outros princípios fundamentais, como a privacidade, a autodeterminação, a integridade física e mental, etc., deve ser oposto o caráter concreto e autoaplicável da dignidade humana, expresso na vida concreta de cada sujeito particularizado a partir do paradigma da razão comunicativa: a língua é uma condição essencial à existência da possibilidade humana (HABERMAS, 2003); a partir daí, a vida não é somente o primeiro e fundamental direito a ser protegido pela lei; é, mais, a própria condição primária de possibilidade de quaisquer outros direitos. Desenvolvese, assim, o conceito de supremacia absoluta da vida humana, vida que, para ser entendida como tal, deve ser digna.

Esse paradigma impõe pensar a vida sob um aspecto material, ou seja, o ponto de partida desse paradigma é a vida com um conteúdo propriamente material, pois a vida é, sobretudo, vida concreta, biológica ${ }^{10}$. Nesse contexto, o núcleo do princípio da dignidade não supõe apenas garantir a proteção da dignidade humana no sentido de assegurar para a pessoa, de forma genérica e abstrata, um tratamento não degradante, tampouco significa o simples oferecimento de garantias à integridade física ou psíquica do ser humano: nesse ambiente, de um renovado humanismo, a vulnerabilidade humana será tutelada de forma prioritária onde quer que se manifeste, e como se manifeste, de modo que sempre terão preferência os direitos e as necessidades de certos grupos sociais considerados, de uma forma ou de outra, mais vulneráveis, e que estão, assim, a exigir uma proteção especial: as crianças e os adolescentes, os idosos, os portadores de deficiências físicas ou mentais, os consumidores, os trabalhadores, os desempregados, os pobres e os membros de minorias étnico-raciais, entre outros.

Está claro que, nessa dimensão, é impossível reduzir a uma fórmula genérica e abstrata a priori tudo aquilo que constitui o núcleo da dignidade humana. Assim, essa discussão sobre o respeito à dignidade humana e à consequente delimitação do seu conteúdo só pode ser levada a cabo no caso concreto, quando se possa perceber uma efetiva agressão à dignidade da pessoa.

\footnotetext{
${ }^{10}$ Assim, podemos afirmar que a vida nunca poderá ser reduzida a uma ideia, a uma abstração, dado seu substrato concreto, físico e biológico. Nesse sentido, v. Maturana e Varela (2001).
} 
Nesse contexto, parece-nos claro que a materialidade do princípio da dignidade humana assenta-se sobre o denominado "mínimo existencial"11.

Por isso, é necessária a adoção de uma nova visão sobre os direitos sociais, pois a efetividade de quaisquer direitos humanos fundamentais, vinculados à dignidade humana e relacionados à liberdade e à autonomia da pessoa, não é possível sem a garantia, para ela, do mínimo existencial, condicionado econômica, social e culturalmente. Isso implica refutar o processo liberal de banalização - que destitui, na prática, a autoridade dos direitos humanos fundamentais - e de fragmentação teórica dos direitos humanos fundamentais (FERRAZ JUNIOR, 2007), repensando esses direitos e as suas garantias, pois a concretização dos chamados direitos sociais não pode ser considerada separadamente da consolidação da própria democracia e dos direitos civis e políticos: a realização da cidadania real, imprescindível para a democracia, requer reformas econômicas, sociais e culturais para a remoção dos obstáculos que a impedem (DIMENSTEIN, 2006).

De fato, o próprio significado social de "pessoa" está relacionado com as diferentes posições que cada um de nós ocupa - e através das quais atuamos - dentro de cada campo concreto (BOURDIEU, 2000), e essas posições, cujo conjunto constitui a nossa definição social de pessoa, estão definidas dentro de cada campo de tal forma que nos permitem determinadas práticas sociais e nos impedem ou restringem outras. Disso tudo, verifica-se que, dentro de cada campo, as posições não são igualitárias; ao contrário, uma das características mais destacadas desses campos é a distribuição diferente - substancialmente diversificada e estratificada - de certos atributos entre as posições ocupadas pelos indivíduos. É justamente essa distribuição diferente que conforma a base de certas definições sociais diferenciadas das posições; umas em relação às outras, as diferentes posições têm estabelecidas entre si a forma como deveriam relacionar-se reciprocamente: como iguais, em superioridade (uma com mais poder e/ou influência sobre a outra), em inferioridade, ou, mesmo, não poderem, nem deverem relacionarse (TORRAZZA, 2006).

Pobre, desempregado, analfabeto, etc. são categorias que determinam a posição das pessoas e, consequentemente, estabelecem um tratamento determinado por parte dos demais atores do campo, ao mesmo tempo em que faz com que aqueles que ocupem determinada posição esperem do restante determinado tratamento, em um processo cultural de

\footnotetext{
${ }^{11}$ Segundo Barcellos (2002, p. 198), o mínimo existencial corresponde ao conjunto de situações materiais indispensáveis para a existência humana digna: o mínimo existencial e o núcleo material da dignidade humana correspondem ao mesmo fenômeno.
} 
institucionalização das diferenças, das discriminações e das clivagens econômicas, sociais e culturais como parte de um esquema de reprodução social e de dominação.

Nesse contexto, em relação aos direitos humanos e à dignidade humana, a posição da pessoa como nexo entre a ideia abstrata de pessoa e a nossa práxis em relação ao conjunto de posições deveria refletir um conjunto de direitos - e correspondentes deveres implícitos - que decorrem da igual dignidade de todas as pessoas. Mas a existência social das pessoas concretas caracteriza-se, de fato, por uma constante restrição e vulneração desses direitos como resultado das diversas práticas e definições que se estabelecem. Conclui-se, assim, que os direitos abstratos se concretizam em cada campo através das práticas resultantes do jogo entre as diferentes posições: a igualdade real deixa de existir, já que cada campo comporta uma distribuição de atributos e bens considerados escassos e que se vertem em verdadeiros privilégios. Para sustentar essa distribuição desigual de atributos e bens, cada campo tem organizados mecanismos reprodutivos que atuam sincrônica e diacronicamente, e que tendem a afetar - e, em geral, a acentuar - essas distintas atribuições de direitos e deveres às posições.

O controle desses mecanismos reprodutivos concentra-se nas posições privilegiadas de cada campo, seja porque aqueles que as ostentam exercem um controle direto desses mecanismos, concretamente, seja porque exercem sobre eles um controle simbólico (ALTHUSSER, 1977). Dessa forma, o próprio conceito de sociedade conforma-se a uma estrutura de campos em que as pessoas, através de suas posições (com as suas definições e os seus privilégios), relacionam-se entre si, estabelecem práticas sociais e perpetuam-se diversas clivagens - étnicas, de gênero, de status social ou econômico, etc.- e desiguais distribuições de bens e direitos econômicos, sociais e culturais.

Falar de direitos humanos e, consequentemente, de dignidade humana é, portanto, falar de fazer acessíveis os direitos sociais a grupos humanos que habitualmente não têm pleno acesso a esses direitos. Ou seja, trata-se de abrir um caminho novo, verdadeiramente alternativo e real, a uma cidadania não excludente, democrática em seu sentido participativo e devotada para uma práxis autenticamente transformadora da própria sociedade. Para colocá-lo em marcha é necessária grande energia e vontade política, mas também, concomitantemente, é necessária uma grande capacidade técnica para (re)idealizar os conteúdos e as técnicas que nos permitam (re)pensar os direitos sociais, as suas garantias e a própria atuação do Estado democrático de direito (PEREIRA, DIAS, 2008). 
4. Especificação e reclamo dos direitos humanos fundamentais - um problema não só das instituições jurídicas, mas generalizado no desenho de todos os segmentos da sociedade

As instituições jurídicas e o direito podem ser instrumentos de opressão social quando estão apartados da democracia; no entanto, com a democracia participativa e a fortaleza da cidadania, o direito pode desvelar-se uma instituição coletiva de libertação ${ }^{12}$. Evidentemente, não pode haver cidadania significativa sem democracia, tampouco um modelo de democracia pode ser substancialmente democrático sem cidadania real. É necessário, portanto, reconstruir algumas premissas do campo jurídico para um direito posto não apenas como um instrumento de defesa social frente às arbitrariedades, mas também como um instrumento de tutela da própria cidadania real em um contexto inclusivo e de construção permanente de um modelo de desenvolvimento mais humano, mais justo e mais democrático, pondo em marcha atos concretos e orientados à plena efetividade dos direitos sociais, por todos os meios possíveis, empregando o máximo de recursos disponíveis.

Uma revisão modernizadora dos direitos humanos fundamentais que recorra à argumentação crítica e à concertação social, conciliando diferentes vertentes, poderia ativar mecanismos de formação de opinião pública críticos e politicamente relevantes, que poderiam atuar em todos os planos, restaurando o ponto inicial de partida dos direitos humanos, que foi o germe do liberalismo político iluminista.

A forma universal dos direitos humanos, e sua fundamentalidade nos ordenamentos particulares, corresponde à exigência de uma ordem mundial na qual todos os homens possam realmente desfrutar de todos os seus direitos humanos e fundamentais. O processo de especificação e reclamo de conteúdos particulares para a forma universal dos direitos humanos é um processo empírico e coletivo de aprendizagem moral e política. Sua dinâmica processual tem que corresponder às normas definidas - ou definíveis - de um discurso argumentativo negocial sobre normas morais controvertidas, ao menos para que as convenções obtidas na (pela) comunidade real particular de comunicação e argumentação possam ser enunciadas e apresentadas como válidas para todos os homens.

\footnotetext{
${ }^{12}$ Não nos parece difícil perceber que se as normas são criadas pelos próprios interessados em vê-las cumpridas, através da cooperação dos atores sociais fundada no binômio autonomia-solidariedade, sua materialização está muito mais presente na autonomia do que em casos de anomia ou heteronomia - é necessário envolver, pois, todos os participantes na produção, interpretação e aplicação das normas; "de allí la efectividad normativa legítima- y el modelo normativo de acción está, además, asociado a un claro modelo democrático de aprendizaje y de autoreconocimiento que tiene en cuenta la interiorización de valores" (cf. Habermas, 2005, p. 129).
} 
Um exemplo de uma comunidade complexa desse tipo foi a conferência da Organização das Nações Unidas em Viena, em 1993, sobre direitos humanos. Nela, representantes de Estados, comissários de diferentes organizações civis não governamentais e militantes de direitos humanos formaram uma comunidade de argumentação e comunicação claramente orientada pela busca de concretização dos conteúdos que dariam eficácia às normas universais que os direitos humanos supostamente são.

Instrumentalmente, portanto, os direitos de informação, comunicação e argumentação são direitos de extrema relevância porque todos os demais direitos pactuados dependem de três fatores: a) que cada homem queira ter uma ideia correta de como os outros homens querem e/ou necessitam viver; b) que todos possamos comparar essas ideias de modo mais ou menos equivalente; e c) que nos coloquemos de acordo sobre tais questões na sua raiz, e não nos limites que os mais poderosos tenham decidido fixar.

Para que possamos comparar tais ideias equivalentes no quadro das diversidades e nos colocarmos de acordo ao seu respeito, não há necessidade de um modelo de racionalidade particularmente ambicioso ou especializado, e por isso mesmo talvez culturalmente relativo. Para esse fim basta a racionalidade que se emprega habitualmente para estabelecer um diálogo e para oferecer e ponderar argumentos: a razão argumentativa. É de supor que cada um disponha de "suficiente razão" (racionalismo) para dialogar com outro, em uma argumentação discursiva, em torno de questões comuns a ambos. Nesse contexto, a razão argumentativa ou a racionalidade discursiva consiste em um poder e em um saber articular (e revisar) as nossas pretensões de validez, os nossos fundamentos e as nossas experiências, tudo isso sem que nos esqueçamos dos outros (APEL, KETTNER, 1996).

A articulação de todos os processos possíveis de autodeterminação coletiva sobre um problema de referência, em que é preservada, fortalecida e protegida a autonomia de cada um, sem que a autonomia operacional de um venha a ser sacrificada em benefício da autonomia de outro, é o que os direitos humanos têm em comum com o liberalismo político - e o que eles têm a ver com os direitos sociais. Portanto, não só pouco, mas, na realidade, nada teriam a ver com o liberalismo econômico.

Direitos humanos fundamentais - civis, políticos e sociais - devem ser um problema universal, não só abstrato, intelectual, mas generalizado no desenho de todos os segmentos da sociedade. Deve ser exigida generalização e universalidade para todos os direitos humanos fundamentais, civis, políticos e sociais. Generalização no sentido de que esses direitos são para todos e por todos; universalidade no sentido do componente metafísico da concepção da pessoa humana, independentemente de etnia, religião, preferências sexuais, cultura ou gênero (SAID, 
1993). Não parece existir nenhuma razão para que continuemos insistindo na separação e na distinção dos homens, classificando-os e hierarquizando-os.

Assim, os direitos sociais, direitos que sustentam o conceito de mínimo existencial, não podem deixar de ser concretizados sem que se viole profundamente esse valor supremo que é a dignidade humana. Para isso, o Estado-Executivo institui entidades públicas, ligadas à administração pública, para que diretamente, ou mediante cooperação com entidades do setor privado, formulem e executem as políticas públicas sociais mais adequadas às necessidades da população que atendem: uma administração pública democrática de direito, ou seja, uma administração pública que, quando está promovendo os seus atos oficiais, cumprindo as suas atribuições normativas e políticas de acordo com o interesse público, o faz respeitando e perseguindo os ditames concernentes à realização da justiça social e dos direitos fundamentais - civis, políticos, sociais - que articulam a cidadania moderna: uma boa administração pública, uma administração pública eficiente e eficaz, uma administração pública dialógica.

Os direitos sociais foram sucessivamente constitucionalizados no século vinte, sendo, assim, sucessivamente proclamados como direitos fundamentais, deixando-se para trás os limites do Estado Liberal e as suas arcaicas formulações. As contradições entre os princípios do Estado Liberal e os do Estado Social foram superadas pelo Estado democrático de direito, que se vincula a uma concepção material (e não meramente processual) de democracia como participação também em resultados, o que exige, para os direitos sociais fundamentais dos cidadãos/administrados, uma configuração jurídico-política e uma interpretação coerente com esses supremos princípios democráticos.

O Estado de direito, como expomos, corresponde à institucionalização jurídicopolítica da democracia, sendo a sua razão de ser a proteção e a efetiva realização dos direitos fundamentais, incluindo os direitos sociais (PECES-BARBA, 2004). O fundamento de validez da democracia pluralista radica na autonomia moral do ser humano como fim em si mesmo, participante em um duplo sentido na constituição do próprio sistema, através da formação da lei (participação nas deliberações) e através da participação nos resultados sociais. Tais direitos, contudo, não presumem que os seres humanos são seres autônomos, livres e iguais, mas predicam que os homens devam sê-lo e que para isso são necessários contextos institucionais adequados que o façam possível - os direitos fundamentais seriam, assim, os instrumentos adequados para isso. Nessas condições, os direitos fundamentais são o fundamento de legitimidade tanto de una teoria da justiça quanto de uma teoria da autoridade.

Sustentar que os direitos fundamentais são um critério de legitimidade com projeção tanto na teoria da justiça quanto na teoria da autoridade tem, evidentemente, implicações na 
relação, às vezes (aparentemente) contraditória, entre direitos fundamentais e democracia em contextos constitucionais (ALEXY, 2003). Evidentemente, o constitucionalismo impõe limites sobre o princípio majoritário em dois âmbitos especialmente, ao considerar os direitos fundamentais como um âmbito protegido frente ao legislador ordinário e ao administrador de turno e ao atribuir o controle de constitucionalidade a um órgão cuja justificação não é coincidente com a legitimidade democrática primária (ou seja, com a regra de maioria). Nesse debate convém, contudo, não perder o horizonte e tomar consciência das distâncias entre o ideal democrático e a realidade constitucional de cada momento; daí que esta exija recorrer a uma série de ficções funcionais para manter o equilíbrio entre a Constituição e a democracia, entre o fundamento democrático do poder político e a limitação deste pelos direitos fundamentais (PRIETO, 2003).

Nesse contexto, onde os direitos fundamentais são, antes de tudo, condição necessária para que o seu titular possa desenvolver-se como agente moral em um contexto dado, e concomitante fundamento de legitimidade dos sistemas jurídicos, as normas são legítimas porque são necessárias para o desenvolvimento da autonomia individual, e, portanto, a competência normativa é legítima se - e somente se - deriva do exercício da autonomia pelos destinatários das normas (ou seja, do consentimento social), e as normas são justas se - e somente se - têm como conteúdo a proteção e a promoção dessa mesma autonomia (HIERRO, 2000). E, nesse sentido, essas normas devem estar adstritas às condições constitutivas de uma prática de formação discursivo-pública da opinião e da vontade (HABERMAS, 2005); por isso formam parte da própria estrutura constitutiva da práxis democrática e, concomitantemente, a sua configuração jurídica resta confiada aos resultados do exercício da mesma.

A partir disso, o modelo constitucional ideal atribui ao procedimento democrático maior valor moral que a qualquer outro (DÍAZ, 1984), pois, em linha de princípios, este é a expressão do direito à igualdade moral como direito à participação em pé de igualdade na tomada de decisões públicas, corolário da ideia de que todos somos merecedores de igual consideração e respeito. O modelo constitucional, por outro lado, conta, em seu âmago, com uma gama de submodalidades que vão desde a maior rigidez do mesmo até formas de composição mais flexíveis. A justificação institucional de cada uma dessas submodalidades depende da forma com que se combinam ou equilibram o valor intrínseco do procedimento democrático e o seu valor instrumental: a maior ou menor probabilidade de alcançar resultados justos (BAYÓN, 2005). Em termos absolutamente gerais, podemos afirmar que as respostas se encontram em dois terrenos, no dos direitos fundamentais e no do controle de constitucionalidade. Mas não se tratam de distintas questões, com distintos alcances e 
pressupostos. Se, como sustentamos, a legitimidade das normas deriva de serem essas normas o resultado da autonomia moral em condições de igualdade, e se as normas são legítimas se protegem e promovem essa mesma autonomia, os direitos impõem limites ao legislador - e também ao administrador - e atuam como uma espécie de precompromisso no âmbito da deliberação (MORESO, 2000): a base da tomada de decisões deveria, portanto, assemelhar-se cada vez mais à democracia participativa real de pessoas e grupos.

A exigência de constitucionalização dos direitos está vinculada à especial posição que ocupam os direitos fundamentais no Estado constitucional (PRIETO, 2003), que se manifesta em um reforço de suas garantias ou de sua resistência jurídica frente a eventuais lesões originadas da práxis dos poderes públicos - e também das relações entre particulares. As dúvidas sobre a constitucionalização das políticas públicas sociais têm que ser resolvidas atentando-se para o conteúdo constitucionalmente material do ordenamento e deixando-se ao administrador uma margem para que atue. A limitação do administrador público reside, numa primeira ordem, no dever que tem de sentir-se vinculado ao desenvolvimento e à proteção dos direitos dos cidadãos/administrados. $\mathrm{O}$ administrador está obrigado a ser ativo em relação às normas que, eleitas fundamentais, relacionam-se diretamente com os próprios fins do Estado democrático de direito.

Nesse sentido, argumenta-se que a inatividade é inconstitucional; ou seja, que o administrador pode determinar como quer concretizar um direito, dentro da margem de discricionariedade que lhe é dada pelo próprio ordenamento, mas "quando" concretizá-lo não pode permanecer sob a sua discricionariedade. Estaria proibida, portanto, não só a inatividade, mas também a desatenção ao fim - ao programa traçado pela Constituição - por parte dos órgãos do Estado. Ou seja, o administrador público não pode considerar-se desvinculado dos fins constitucionalmente delineados, nem da necessidade de concretizar tais fins. Daí que o administrador público está obrigado a tomar medidas razoáveis em um prazo razoável e a garantir, ao menos, um conteúdo mínimo essencial de todos os direitos fundamentais; assim, além de um dever de progressividade, impõe-se o princípio de não regressividade ou de proibição do retrocesso social, que proíbe à administração pública a supressão daquelas medidas que já tenham sido adotadas para a promoção dos direitos fundamentais: a proibição de suprimir medidas que tendam a realizar o fim constitucionalmente prescrito ${ }^{13}$. O governo assume compromissos prestacionais pelo fato de não poder atuar contra os seus próprios atos (venire contra factum proprium non valet), tampouco contra os direitos fundamentais.

\footnotetext{
${ }^{13}$ Sobre esse princípio, v. Courtis (2006).
} 
Precisamente no Estado democrático de direito, tanto os direitos sociais como os demais direitos fundamentais desempenham um papel extremamente relevante no equilíbrio das posições dos sujeitos implicados no complexo processo de decisão da política em um sistema pluralista (BALDASARRE, 2001). A continuidade axiológica e estrutural de todos os direitos fundamentais põe em evidência que os direitos sociais não são apenas plenamente compatíveis com a democracia, mas constituem um componente essencial dos valores fundamentais da mesma, ancorados na dignidade humana, não havendo, portanto, razões legítimas para a postergação dos direitos sociais. Ao contrário, as exigências morais que estes incorporam são tão fortes que têm a legítima pretensão de serem reconhecidos como direitos subjetivos diante dos poderes públicos e privados, sobretudo frente à administração pública, pois o que faz de algo um direito fundamental são as razões especialmente fortes para que esse algo seja juridicamente protegido com especial zelo pelo próprio instrumento que consubstancia o pacto social instituinte - a Constituição.

\section{Considerações finais}

Todos os direitos, não só os sociais e os de participação, são direitos de configuração legal e concomitantemente administrativa, no sentido de que sua plena eficácia resultaria impensável sem uma ativa intervenção legislativa e administrativa. Os direitos fundamentais de qualquer tipo não prescindem da ação do legislador e do administrador público para a sua concretização, para o seu desenvolvimento e para a sua efetividade. Essa parece ser a interpretação mais coerente com as exigências de uma democracia material-constitucional comprometida com a realização dos direitos relacionados à autonomia de todos em condições de igualdade. Se falamos de direitos fundamentais como parte da legitimidade de um modelo democrático, tanto o legislador quanto o administrador devem ter margens epistêmicas de manobra para regulamentá-los, e assim concretizá-los, mas essas margens não supõem a não concretização, sob qualquer pretexto, desses direitos fundamentais.

A função objetiva das disposições constitucionais em matéria de direitos sociais impõe ao legislador um dever de legislar e deveres de atuação que pesam sobre a administração pública e o Poder Judiciário. Entre essas garantias, está, sobretudo, o império da lei: a garantia do princípio da legalidade é a mais coerente com as exigências democráticas desse modelo de Estado (ANSUATEGUI, 1997). A exigência de respeito ao conteúdo mínimo essencial dos direitos fundamentais, que justifica concomitantemente o controle e a limitação do poder, é coerente com essa ideia de império da lei - atualmente qualificada como império da própria 
Constituição, ou seja, do direito. Logicamente, as dificuldades de identificarmos o conteúdo essencial de um direito fundamental, seja ele civil, político ou social, é a mesma - não é, portanto, algo inerente aos direitos sociais. O conceito de conteúdo essencial, como sabemos, segue sendo demasiadamente difuso e indeterminado, porque é muito difícil eleger critérios minimamente orientativos para delimitar abstratamente o essencial de um direito.

O fundamental, portanto, é compreendermos que os direitos fundamentais, que são interdependentes entre si, formam parte de um sistema constitucional no qual o mínimo e o máximo definem-se através de uma relação com outros direitos ou bens do próprio sistema. Em qualquer caso, a falta de respeito a esse conteúdo mínimo supõe que o direito resta desconfigurado, impraticável; seu exercício pode acabar desvirtuando-se e a dignidade dos seus destinatários afrontada. Esse limite pode ser visualizado em um mínimo de atividade legislativa e administrativa, na satisfação do mínimo existencial e no direito ao não retrocesso nas prestações correspondentes ao núcleo essencial dos direitos sociais.

Evidentemente, tudo isso tem uma especial relação com o controle. A garantia constitucional objetiva compreende um âmbito expandido que consiste no controle de constitucionalidade dos atos e disposições de todos os poderes do Estado - Judiciário e administração pública, sobretudo. O modelo constitucional institucionaliza formas especiais de justiça constitucional que podem articular-se entre si de diversas formas, mas sempre com o propósito de determinar responsabilidades político-constitucionais e equilibrar continuamente as decisões legislativas, administrativas e judiciais com os valores abstratos da Constituição através de uma "razoabilidade" que se resume na exigência de não arbitrariedade.

As funções e relações correspondentes ao legislador, ao administrador e ao julgador, no Estado democrático de direito, exigem uma virtuosa divisão de tarefas. Não podemos, assim, pensar razoavelmente na articulação dos direitos sociais fundamentais no marco do Estado democrático (constitucional e social) de direito sem vinculá-los a três bases:

a) uma liberdade regulatória relativa do legislador e do administrador, especialmente no delineamento das políticas públicas sociais;

b) um legislador e um administrador efetivamente comprometidos com - ou melhor, vinculados ao - conteúdo constitucional dos direitos sociais; e

c) uma jurisdição que, atuando como órgão de controle, reconheça a autoridade do legislador e do administrador na delimitação e na concretização dos direitos sociais fundamentais, reservando para si, embora, o controle sobre aqueles elementos básicos, como o respeito aos direitos sociais fundamentais, indispensavelmente relacionados ao exercício da autonomia e à saúde do próprio procedimento democrático. 
Isso implica refutar, como já expomos, a limitação e/ou postergação de direitos sociais como consequência da incidência de uma lex mercatoria sobre a política e sobre o direito, limitação e/ou postergação que é paralela à que acontece em relação aos direitos de efetiva participação, provocando o incremento das desigualdades econômicas, sociais e culturais, a exclusão de certos segmentos da participação nos resultados sociais e a erosão de garantias.

\section{Referências bibliográficas}

ALEXY, R. Derechos fundamentales y estado constitucional democrático. In: CARBONELL, M. (Org.). Neoconstitucionalismo(s). Madrid, Trotta, 2003.

ALTHUSSER, L. Posiciones. Barcelona: Anagrama, 1977.

ANSUATEGUI, F. J. Poder, ordenamiento jurídico y derechos. Madrid: Dykinson, 1997.

APEL, K.-O.; KETTNER, M. (Org.). Die eine Vernunft und die vielen Rationalitäten . Frankfurt am Main: Suhrkamp, 1996.

ARENDT, H. On revolution. New York: Hortsseiner, 1989.

BALDASARRE, A. Los derechos sociales. Bogotá: Universidad Externado de Colombia, 2001.

BARCELlOS, A. P. A eficácia jurídica dos princípios constitucionais: o princípio da dignidade da pessoa humana. Rio de Janeiro: Renovar, 2002.

BAYÓN, J. C. Democracia y derechos: problemas de fundamentación del constitucionalismo. In: BAYÓN, J. C. et al. Constitución y derechos fundamentales. Madrid: Centro de Estudios Políticos y Constitucionales, 2005.

BÖCKENFÖRDE, E.-W. Demokratie als Verfassungsprinzip. In: ISENSEE, J.; KIRCHHOF, P. (Org.). Handbuch des Staatsrechts. Vol. I. Heidelberg: C. F. Müller, 1987. 
. Staat, Gesellschaft, Freiheit. Studien zur Staatstheorie und zum Verfassungsrecht. Frankfurt am Main: Suhrkamp, 1976.

BOURDIEU, P. Cuestiones de sociología. Madrid: Istmo, 2000.

BRITO, C. A. Poder constituinte versus poder reformador. In: MAUÉS, A. Constituição e democracia. São Paulo: Max Limonad, 2001.

CANOtILHO, J. J. G. Direito constitucional e teoria da constituição. 5.ed. Coimbra: Almedina, 2002.

COURTIS, C. (Org.). Ni un paso atrás: la prohibición de regresividad en materia de derechos sociales. Buenos Aires: CELS, 2006.

DÍAZ, E. De la maldad estatal y la soberanía popular. Madrid: Debate, 1984.

DIMENSTEIN, G. Democracia em pedaços: direitos humanos no Brasil. São Paulo: Schwarcz, 2006.

EIDE, A. et al. (Org.). Economic, social and cultural rights. Dordrecht: Martinus Nijhoff, 1995.

FERRAJOLI, L. et al. Los fundamentos de los derechos fundamentales. Madrid: Trotta, 2001.

FERRAZ JUNIOR, T. S. Direito constitucional. São Paulo: Manole, 2007.

FREIRE, A. M. P. La garantía en el estado constitucional. Madrid: Trotta, 1997.

HABERMAS, J. Consciência moral e agir comunicativo. Rio de Janeiro: Tempo Brasileiro, 2003.

. Facticidad y validez: sobre el derecho y el estado democrático de derecho en términos de teoría del discurso. 4.ed. Madrid: Trotta, 2005. 
HESSE, K. Grundzüge des Verfassungsrechts Bundesrepublik Deutschland. 20.ed. Heidelberg: C. F. Müller Juristischer Verlag, 1995.

. Temas fundamentais do direito constitucional. São Paulo: Saraiva, 2009.

HIERRO, L.¿Qué derechos tenemos? Doxa: Cuadernos de Filosofía del Derecho, n. 23, Madrid, 2000.

JELLINEK, G. Algemeine Stastslehre. Berlin: Springer, 1921.

KANT, I. Fundamentação da metafísica dos costumes. In: Crítica da razão pura e outros textos. São Paulo: Abril Cultural, 1974.

LEAL, R. G. Estado, administração pública e sociedade: novos paradigmas. Porto Alegre: Livraria do Advogado, 2006.

MARGALIT, A. Politik der Würde: über Achtung und Verachtung. Berlin: Fischer, 1997.

MATTEUCCI, N. Organizzazione del potere e libertà. Torino: Utet, 1976.

MATURANA, H.; VARELA, F. A árvore do conhecimento: as bases biológicas da compreensão humana. São Paulo: Palas Athena, 2001.

MORESO, J. J. Sobre el alcance del precompromiso. Discusiones, n. 1, Bahía Blanca, 2000.

PECES-BARBA, G. La cultura jurídico-política de la constitución de 1978. In: PECESBARBA, G.; RAMIRO, M. A. (Org.). La Constitución a examen: un estudio académico 25 años después. Madrid: Marcial Pons, 2004.

PEREIRA, F. H. U.; DIAS, M. T. F. Cidadania e inclusão social. Belo Horizonte: Fórum, 2008.

PISARELLO, G. Los derechos sociales y sus garantías. Madrid: Trotta, 2007.

PRIETO, L. Justicia constitucional y derechos fundamentales. Madrid: Trotta, 2003. 
RESTA, E. Il diritto fraterno. 3.ed. Roma: Laterza, 2005.

SADEK. M. T. (Org.). Reforma do poder judiciário. São Paulo: Konrad Adenauer, 2001.

SAID, E. Culture and imperialism. London: Chatto and Windus, 1993.

SCHMIDT-ASSMAN, E. Der Verfassungsbegriff in der deutschen Staatslehre der Aufklärung un der Historismus. Berlin: Duncker \& Humblot, 1967.

SCHWARZ, R. G. O sistema de seguridade social e o princípio da solidariedade. In: BARROSO, L. R.; CLÈVE, C. M. (Org.). Direito constitucional: constituição financeira, econômica e social. São Paulo: RT, 2011.

SMENDE, R. Verfassung und Verfassungsrecht, Staatrechtliche Abhandlungen und an- dere. 2.ed. Berlin: Aufsatze, 1968.

TORRAZZA, J. Z. Inmigración y prácticas sociales discriminatorias. In: BERGALLI, R. (Org.). Flujos migratorios y su (des)control. Barcelona: Anthropos, 2006.

WARAT, L. Fobia al estado de derecho. Anais do curso de pós-graduação em Direito da Universidade Integrada do Alto Uruguai e Missões. Santiago: URI, 1994.

ZAMBRANO, M. Pensamiento y poesía en la vida española. México: FCE, 2008. 


\title{
TRABALHO ESCRAVO: TRAÇOS CRÍTICOS NA CONTEMPORANEIDADE
}

\author{
Laiane Aparecida Dantas de Oliveira \\ Universidade Fumec \\ Letícia da Silva Almeida \\ Universidade Fumec
}

\begin{abstract}
Resumo
O presente artigo tem por finalidade demonstrar que o trabalho escravo ainda é uma realidade, ainda que expressamente proibido entre os países democráticos. Traz à tona uma discussão sobre o que é a escravidão contemporânea, como age e se descaracteriza e ainda sobre a omissão de países, como exemplo, o Brasil, em casos emblemáticos. Utilizado o método dedutivo, por meio da pesquisa bibliográfica. $\mathrm{O}$ marco teórico está na dignidade da pessoa humana como preceito fundamental do Estado Democrático de Direito, na obra de Ricardo Rezende Figueira.
\end{abstract}

Palavras-chave: Trabalho escravo, Exploração, Brasil e Espanha, Corte Interamericana de Diretos Humanos, Dignidade Humana.

\begin{abstract}
Resumen/Résumé
The purpose of this article is to demonstrate that slave labor is still a reality, even though it is expressly prohibited among democratic countries. It brings up a discussion about what contemporary slavery is, how it acts and is discharacterized, and also about the omission of countries as emissions, as an example, Brazil, in emblematic cases. Used the deductive method, through bibliographic research. The theoretical framework lies in the dignity of the human person as a fundamental precept of the Democratic State of Law, in the work of Ricardo Rezende Figueira.
\end{abstract}

Keywords/Palabras-claves/Mots-clés: Slavery, Exploration, Brazil, Spain, Inter-American Court of Human Rights, Human dignity. 


\section{Introdução}

O trabalho e seu desempenho em boas condições, ou seja, o trabalho digno, é direito basilar na Constituição da República Federativa do Brasil (CR/88), e como todas as outras normas Constitucionais, deve ser interpretado a luz do Princípio da Dignidade da Pessoa Humana. Trata-se de um direito-dever como é tratado na Constituição Espanhola de 1978, em seu art. 35, que enquanto Estado Democrático de Direito, assegurou igualdade e condições e salários independente do sexo.

O trabalho degradante em condição análoga a de escravo, tem origem antiga e marcou presença nas sociedades em diferentes épocas. Embora distintas discussões em diversos segmentos filosóficos, científicos, culturais e sociais é um tema pouco difundido no meio acadêmico jurídico.

No século XXI, falar sobre trabalho escravo é um estigma. Isso porque, parece aos olhos da sociedade não existir. No entanto, esse tipo de trabalho é uma realidade negativa no cenário atual. Tal situação afronta a Dignidade Humana estampada na CR/88 e os Direitos de proteção ao trabalhador.

Foi utilizado o método dedutivo, por meio da pesquisa bibliográfica. O marco teórico está na dignidade da pessoa humana como preceito fundamental do Estado Democrático de Direito, na obra de Ricardo Rezende Figueira.

\section{Cronologia histórica do trabalho escravo no brasil $x$ espanha: do passado ao presente}

Antes de iniciar propriamente a temática do trabalho escravo contemporâneo, faz-se necessário a breve abordagem histórica do referido tema como forma de esclarecer seu surgimento, para que haja um entendimento de seus reflexos ${ }^{1}$ até os dias atuais.

A Organização Internacional do Trabalho define como trabalho decente "aquele trabalho adequadamente remunerado, exercido em condições de liberdade, equidade e segurança, capaz de garantir uma vida digna”. (ORGANIZAÇÃO, 2011). Por outro lado, considera-se trabalho escravo, nas palavras de Jairo Lins de Albuquerque Sento-Sé:

\footnotetext{
${ }^{1}$ Um dos maiores reflexos do modelo de escravidão antigo é sua herança atual. Um modelo tão antigo e preconceituoso de uma época onde não se falava em Dignidade da Pessoa Humana, Direitos Humanos e seus tratados Internacionais, consegue perpetuar até a presente geração onde não se discute mais a existência do ser humano como sujeito de direitos.
} 
[...] trabalho escravo é aquele em que o empregador sujeita o empregado a condições de trabalho degradantes, inclusive quanto ao meio ambiente em que irá realizar sua atividade laboral, submetendo-o, em geral, a constrangimento físico e moral que vai desde a deformação do seu consentimento ao celebrar o vínculo empregatício, passando pela proibição imposta ao obreiro de resilir o vínculo quando bem entender, tudo motivado pelo interesse mesquinho de ampliar os lucros às custas da exploração do trabalhador (SENTO-SÉ, 2001, p. 27).

O Trabalho escravo permeia a sociedade desde tempos remotos, ou seja, sua origem galga a existência humana em sociedade, nunca foi abolido, nada mudou, embora, a forma de sua caracterização sim.

Nas palavras de Antônio Almeida, “[...] a humanidade e a escravidão têm sua trajetória ligada, portanto, se torna difícil precisar onde se originou e o que causou no princípio.” (FIGUEIRA, 2008, p.15).

Ainda neste sentido, de acordo com Suely Robles Reis Queiroz:

[...] A escravidão é instituição tão antiga quanto o gênero humano e de amplitude universal, pois, legitimada pelo direito do mais forte, ocorreu em todos os tempos e em todas as sociedades. Basta a leitura da Bíblia ou de outros livros que também tratem de épocas remotas para se ter uma idéia de sua antiguidade. No Egito, por exemplo, foram os escravos que ergueram as pirâmides destinadas a perpetuar a glória dos faraós. Da Babilônia de Hamurabi à Fenícia, da Grécia clássica à Roma também clássica, a grande maioria dos povos antigos conheceu a escravidão [...]. (QUEIRÓZ,1993, p. 5-6).

No Brasil, não foi diferente. Sua origem escravista começa com a exploração dos índios ${ }^{2}$, através do escambo ${ }^{3}$, porteriormente escraviza-se os africanos, que chegaram as terras brasileiras em São Vicente ${ }^{4}$.

Nas palavras de Milton Metzer:

[...] quem tinha escravo tinha poder, poderia exibi-los em locais públicos, dar de presente aos amigos, e com o passar dos anos os escravos acabaram se tornando uma maneira de favorecer os poderosos, acrescentar números aos exércitos e assegurar que os serviços públicos fossem feitos. (MELTZER, 2004, p. 38).

\footnotetext{
${ }^{2}$ Alguns autores, a exemplo, Milton Metzer e Agostinho Malheiro, afirmam que o trabalho indígena foi proibido a partir de um decreto feito em 1757 por Marques de Pombal, devido a forte pressão dos Jesuítas.

${ }^{3}$ Em troca de trabalhos, os índios recebiam mercadorias (espelho, roupas e outros).

${ }^{4}$ A Capitania de São Vicente foi uma das capitanias hereditárias originais, de 1534. (MALHEIRO, 1850, p.102).
} 
O trabalho escravo nunca deixou de ser uma realidade brasileira, mesmo tendo sido proibido quando da abolição da escravatura ${ }^{5}$ (abolido pela Lei Áurea ${ }^{6}$ em 13 de maio de 1888 - Lei Imperial n. ${ }^{\circ} 3.353$ ):

A Princesa Imperial Regente, em nome de Sua Majestade o Imperador, o senhor Dom Pedro II faz saber a todos os súditos do Império que a Assembléia Geral decretou e Ela sancionou a Lei seguinte: Art I - É declarada extinta desde a data desta lei a escravidão no Brasil. (BRASIL, 1888).

Realidade não muito distinta do Brasil, a Espanha no século XVI, possuía como bem mais precioso local, a mão de obra das comunidades indígenas, assim foi instituída a primeira forma de trabalho. A extração de minério, as primeiras construções de prédios e pontes por exemplo, foram atividades executadas em sua maior parte pelo trabalho forçado da comunidade indígena.

Agostinho Marques Perdigão Malheiro ${ }^{7}$, afirmava que:

A escravidão é um dos maiores males que ora pesa sobre Vós. Cumpre examinar de perto as questões que ela sugere, e atacá-la com prudência, mas francamente e com energia, para que cessem as ilusões, e não durmam os Brasileiros o sono da indiferença, e da confiança infantil, sobre o vulcão e o abismo, criados pelo elemento servil da nossa sociedade. (MALHEIRO, 1850, p.92).

Mas a escravidão não é somente realidade da sociedade brasileira, em países Europeus, aqui em foco a Espanha, também tem ocorrido tais situações:

Dos cerca de 3,5 milhões de imigrantes ilegais que estão na Europa, 250 mil trabalham sob condições de semelhantes a de escravidão na Espanha, segundo relatório apresentando pela organização não-governamental Cecra (Coalizão Espanhola contra o Racismo, a Xenofobia e a Discriminação).

De acordo com o estudo, a maioria dos imigrantes ilegais é latino-americana e trabalha com serviços domésticos, na prostituição, na agricultura ou na indústria têxtil. Na maioria dos casos, os patrões são pessoas em boa situação econômica e também cultural. (FOLHA ONLINE, 2002).

\footnotetext{
${ }^{5}$ A partir desta data a escravidão torna-se ilegal, entretanto, não houve uma mudança na mentalidade escravocrata.

${ }^{6}$ Lei Imperial n. ${ }^{\circ} 3.353$, sancionada em 13 de maio de 1888, foi o diploma legal que extinguiu a escravidão no Brasil. (BRASIL, 1888).

${ }^{7}$ Jurista na época do império, que não concordava com a escravidão. (MALHEIRO, 1850, p.92).
} 
Nesse sentido, cabe trazer a redação da norma penal brasileira em seu art. 149 do Código Penal que define como crime:

Art. 149. Reduzir alguém a condição análoga à de escravo, quer submetendo-o a trabalhos forçados ou a jornada exaustiva, quer sujeitando-o a condições degradantes de trabalho, quer restringindo, por qualquer meio, sua locomoção em razão dívida contraída com o empregador ou preposto:

Pena - reclusão, de dois a oito anos, e multa, além da pena correspondente à violência.

$\S 1^{\circ}$ Nas mesmas penas incorre quem:

I - cerceia o uso de qualquer meio de transporte por parte do trabalhador, com o fim de retê-lo no local de trabalho;

II - mantém vigilância ostensiva no local de trabalho ou se apodera de documentos ou objetos pessoais do trabalhador, com o fim de retê-lo no local de trabalho.

$\S 2^{\circ}$ A pena é aumentada de metade, se o crime é cometido:

I - contra criança ou adolescente;

II - por motivo de preconceito de raça, cor, etnia, religião ou origem. (BRASIL, 1940).

A norma expressa no ordenamento jurídico brasileiro sobre do trabalho em condições degradantes garante mais uma vez a proteção a Dignidade da Pessoa Humana.

Apesar da clareza da norma penal, o texto ainda provoca interpretações diversas. Nesse sentido, importante Mário Sérgio Beltrão Pamplona explica:

Apesar da existência de norma penal aplicável àquele que se assenhoreia do trabalho degradante em estado similar ao de escravo, alguns interpretes podem entender que existem lacunas a serem preenchidas, ao argumento, por exemplo, de que o conceito de trabalho degradante é relativo, com o que não se concorda, pois o Direito interpretado pelo ir e vir hermenêutico suprailustrado, não dá margem para as ilusórias lacunas. Sob o pálio da argumentação de que a norma penal é clara, mas é injusta para com o empregador por prever o cerceamento de sua liberdade, por graves infrações trabalhistas cometidas, que, a um juízo restritivo, nao revelam a existência de trabalho degradante em conjuntura correlata à de escravo, a eficácia da norma resta comprometida e reforça a sensação de impunidade. (PAMPLONA, 2016, p. 126).

O tipo penal citado é amplo e abrangente visando abolir todo e qualquer tipo de situação não condizente com as necessidades do ser humano, não se limitando apenas a falta de liberdade para que se configure o trabalho escravo. 
Além da utilização do tipo penal, também se tem utilizado a norma Trabalhista e a invocação de Tratados Internacionais da OIT nas decisões judiciais brasileiras.

Na Espanha, a luta contra a exploração do trabalho e o tráfico de pessoas para esta finalidade, enfrenta lacunas na legislação. De acordo com reportagem do jornal El País de Madri, as vítimas podem ser homens ou mulheres, geralmente de origem rural e são destinados a trabalhos em oficinas têxteis, bares, restaurantes, dentre outros. "Só nestes dois anos foram presas 534 pessoas". "[...] A Lei precisa de uma reforma profunda que esclareça conceitos, porque é muito difícil determinar o que é exploração trabalhista pura e o que são condições abaixo das normas" (VILLANUEVA, 2016).

Em outra notícia, agora do jornal RTP Notícias de Portugal:

\begin{abstract}
A Polícia Judiciária do Porto resgatou dezenas de portugueses, que prestavam trabalho escravo em Espanha. Foram detidas sete pessoas em Portugal, que já foram presentes ao juiz e estão indiciadas por associação criminosa, sequestro e tráfico de pessoas. Em Espanha foram detidas outras 19 pessoas, suspeitas de integrarem a mesma organização criminosa angariadora de mão-de-obra ilegal. Estes detidos devem ser entregues às autoridades portuguesas após cumpridos os preceitos legais.

[...] A alegada organização criminosa tentava levar cidadãos nacionais em situação vulnerável: residentes perto da fronteira, com dificuldades económicas, psicologicamente debilitadas e algumas com problemas de alcoolismo e toxicodependência.

Aqueles que cediam ao aliciamento eram transportados para Espanha, onde ficavam submetidos a um regime de cativeiro semelhante à escravidão. Os trabalhadores estariam sujeitos a agressões físicas e sexuais.

Operários agrícolas e das vindimas, que viviam nas províncias de La Rioja, Alava e Navarra e que recebiam entre 10 a 15 euros por semana, ou mesmo sem remuneração, também foram vítimas desta rede.

A investigação, que começou em 2002, apurou que a rede terá escravizado pessoas durante oito anos. (RTP notícias, 2008).
\end{abstract}

Assim, é obvio que ainda no seculo XXI a ofensa a dignidade da pessoa humana é real, em razão de praticas como as supracitadas, que ocorrem não só no Brasil como na Espanha e em tantos outros países.

\title{
3. Trabalho escravo na contemporâneidade
}

Muito se sabe sobre a escravidão antiga, pouco se quer ver sobre a escravidão nova. $O$ trabalho escravo como já dito, nunca deixou de exirtir, só se usou de roupagens diferentes. $\mathrm{O}$ que antes se media pela cor, hoje se mede pela classe social.

Quem são os escravos hoje? Pessoas de baixa ou nenhuma renda. Que se "vendem" por não terem outras oportunidades. 
Pessoas que se sujeitam as condições análogas a de escravo, são aliciadas para aceitarem a proposta de "trabalho". Buscam melhores condições financeiras na esperança de sustentarem suas famílias e acabam vítimas de uma fraude. As promessas são inúmeras, embora a realidade seja: péssimas condições de vida, falta de higiene no local de trabalho, falta de dormitório, proibição de sair do local onde estejam, não há alimentação suficientes, servidão por dívidas $^{8}$, dentre outras condições degradantes.

José Cláudio Monteiro de Brito Filho afirma que se o trabalhador presta serviços exposto à falta de segurança e com riscos à sua saúde, temos o trabalho em condições degradantes. Se as condições de trabalho mais básicas são negadas ao trabalhador, como o direito de trabalhar em jornada razoável e que proteja sua saúde, garantir-lhe descanso e o convívio social, há trabalho em condições degradantes. Se, para prestar o trabalho, o trabalhador tem limitações na sua alimentação, na sua higiene, e na sua moradia, caracteriza-se o trabalho em condições degradantes. Se o trabalhador não recebe o devido respeito que merece como ser humano, sendo, por exemplo, assediado moral ou sexualmente, existe trabalho em condições degradantes (BRITO FILHO, 2014, p. 13-14).

As condições são sujeição de humilhações. Os trabalhadores não possuem qualquer direito trabalhista.

A grande maioria dos trabalhadores são encontrados na zona rural, embora com os números de estrangeiros no país, esta constante começa a ganhar grande visibilidade nos centros urbanos.

Segundo a Organização Internacional do Trabalho (OIT), inúmeros trabalhadores já foram resgatados.

Há uma força-tarefa para tal combate, através de diversos mecanismos criados pelo Governo Federal, além de ONGs, o que ainda não tem como resultado o combate efetivo desta forma de condição degradante de trabalho.

\section{Casos emblemáticos}

O Brasil é signatário de diversas convenções, dentre elas, Convenções da OIT n. ${ }^{0} 29$ (Decreto n. ${ }^{\circ} 41.721 / 1957$ ) e 105 (Decreto n. ${ }^{\circ}$ 58.822/1966), a Convenção sobre Escravatura de

\footnotetext{
${ }^{8}$ Vale ressaltar é tal prática é proibida: Art. 462 - Ao empregador é vedado efetuar qualquer desconto nos salários do empregado, salvo quando este resultar de adiantamentos, de dispositivos de lei ou de contrato coletivo; $\S 4^{\circ}$ Observado o disposto neste Capítulo, é vedado às empresas limitar, por qualquer forma, a liberdade dos empregados de dispor do seu salário. (BRASIL, 1943).
} 
1926 (Decreto n. ${ }^{\circ}$ 58.563/1966) bem como da Convenção Americana sobre Direitos Humanos (Pacto de San José da Costa Rica - Decreto n. ${ }^{\circ}$ 678/1992), todas recepcionadas pela Constituição Federal de 1988. Somos Estado Parte da Convenção Americana desde 25 de setembro de 1992 e reconhecemos a competência contenciosa da Corte em 10 de dezembro de 1998.

A Espanha também aderiu ao movimento global de combate ao trabalho escravo, tendo sido o $13{ }^{\circ}$ país da Europa a ratificar o Protocolo sobre Trabalho Forçado da OIT, o País reforçou o interesse na colaboração dando novo ímpeto a luta contra o trabalho forçado em todas as suas formas.

Desta forma, como um agente estatal, preocupado com as nuances dos direitos humanos, através de tratados já firmados, como dito acima, não deveria ter em sua história, traços de violações a tais direitos, no entanto não é o que ocorre na realidade, como o que ocorreu no Brasil nos dois casos que serão analisados abaixo.

O Caso "Zé Pereira" como ficou conhecido, diz respeito, ao menino José Pereira Ferreira, encontrado em situação de sujeição e degradação, a época com 17 anos, vítima de trabalho escravo na Fazenda Espirito Santo no Pará desde 1987, a partir de então, o Estado brasileiro passou a admitir a existência da escravidão.

Ao chegar ao local, se deparou com uma realidade não esperada. Foi maltratado, recebia ameaças de mortes continuamente, trabalhava de madrugada até o fim do dia.

Diante de tal situação, resolveu fugir com um amigo que conheceu na fazenda denominado "Paraná". Durante a fuga, foram surpreendidos, atiraram em ambos com o intuito de matá-los. Nesta ocasião, Paraná perdeu a vida e Zé Pereira perde a visão de um olho e uma de suas mãos.

As condições degradantes eram nítidas e o sofrimento que passavam suas vítimas podem ser refletidas pelas palavras das próprias vítimas, como nas palavras do Sr. José Pereira Ferreira:

Me chamo José Pereira Ferreira, eu seria apenas mais um dos brasileiros vítimas de trabalho escravo se não fosse o fato de meu caso ter sido denunciado em organismos internacionais e ajudado a combater este crime no Brasil. Por isso, vou contar uma parte da minha história. Tinha 17 anos quando fui trabalhar em uma fazenda no pará. A gente trabalhava do amanhecer até a noite, mas não ganhava nada. Tudo era para pagar alimentação e hospedagem, dizia o gato. A comida era só arroz e feijão. Carne, só quando um boi era atropelado. De noite, a gente era trancado em um barracão de lona e vigiado por capangas armados. Aquilo era insuportável. Então decidi sugir. O Paraná que conheci lá na fazenda me acompanhou. Aproveitamos a distração dos capangas do patrão e ganhamos o mato. A gente sabia que eles viriam atrás da gente, e vieram. Vieram para matar. Atiraram. O paraná caiu morto na hora. Mandaram eu 
andar e atiraram pelas costas. Uma das balas saiu. Saio no olho direito. Me fingi de morto. Nos enrolaram em numa lona. Eu e o corpo do Paraná. E desovaram na beira de uma estrada. Consegui socorro e fui parar em um hospital em Belém. Recuperado voltei com a Polícia Federal a fazenda [...]. Eu perdi a visão do meu olho. Mas me libertei. E ajudei a libertar meus companheiros da desgraça. Mas o Paraná não. Ele não teve indenização, nem liberdade. Só uma cova rasa. Queria mesmo que ele tivesse aqui comigo (FERREIRA, 2016).

O que se vale como reflexão é que, as vítimas (Sr. José e Sr. Paraná), tiveram seus corpos jogados em fazenda vizinha denominada Fazenda Brasil Verde (que vamos abordar adiante como também uma propriedade que praticava o trabalho escravo).

Diante de tal situação, em 1994 a Comissão Pastoral da Terra (CPT), a Center for Justice and International Law (CEJIL - Centro pela Justiça e o Direito Internacional) e Human Rights Watch apresentaram denúncia à Comissão Interamericana de Direitos Humanos (CIDH) da Organização dos Estados Americanos (OEA), relatando o caso e o desinteresse a ineficácia do Brasil nas investigações. Segundo Patrícia Trindade Maranhão Costa:

Isso evidenciou a cumplicidade do Estado, por permitir a persistência de situações de trabalho semelhantes às vivenciadas por José Pereira, além da impunidade, por nenhum funcionário ou proprietário de fazendas ter sido condenado, apesar da violência extrema que caracteriza tais violações e do aumento das denúncias referentes a essas práticas de trabalho[...]. (COSTA, 2008).

Frente a todos os fatos, o Brasil resolve por se fazer uma solução amistosa, o que por sua vez, foi aceito pelas peticionárias, e assinado em 2003.

Neste acordo, foram adotadas algumas medidas em que o Brasil deveria assumir, dentre elas: O reconhecimento público da responsabilidade acerca da violação dos direitos constatada no caso de José Pereira; medidas financeiras de reparação dos danos sofridos pela vítima; compromisso de julgamento e punição dos responsáveis individuais e medidas de prevenção que abarcam modificações legislativas, medidas de fiscalização e repressão do trabalho escravo no Brasil, bem como medidas de sensibilização e informação da sociedade acerca do problema.

Outro caso que merece destaque é o Fazenda Brasil Verde ${ }^{9}$, que foi durante muitos anos um campo de disseminação de trabalho escravo, onde foram aliciados homens e mulheres

\footnotetext{
${ }^{9}$ Fazenda localizada no Pará, nos municípios de Sapucaia. A área total da Fazenda é de 1.780 alqueires $(8.544$ hectares), onde se criam cabeças de gado. O proprietário da Fazenda Brasil Verde no momento dos fatos era João Luis Quagliato Neto. (Comissão Interamericana de Direitos Humanos, 2015).
} 
de idades de 15 ( quinze) a 45 ( quarenta e cinco) anos com promessas de melhores condições de vida e promessas de moradia e salários dignos ${ }^{10}$ o que nunca ocorria.

As condições de trabalho eram degradantes, aonde, não se respeitada nenhum direito e princípios constitucionais. Os trabalhadores eram submetidos a jornadas excessivas de trabalho, a servidão por dívidas, a falta de moradia, dormitório e alimentação inadequada.

As condições humilhantes ao qual se submetiam começava com o trajeto até a FBV, onde viajavam cerca de 3 (três) dias de ônibus, trem e caminhão. Nas viagens de trem eram colocados em vagões de transporte de animais, sem qualquer higiene e assento. Ao chegarem a fazenda, suas carteiras de trabalho eram recolhidas, e obrigatoriamente assinavam documentos em branco.

Dormiam em alojamentos sem energia elétrica, sem cama. O teto era de lona. Não havia banheiros, apenas um chuveiro fora do "dormitório", sem parede. Por vezes, se limpavam nas represas e suas necessidades eram feitas nas vegetações.

Sobre a alimentação, os relatos são de que eram de péssima qualidade e insuficiente, feitas ao ar livre, se alimentavam no mesmo local onde trabalhavam e tomavam água contaminada.

A jornada de trabalho se iniciava as 3 (três) horas da manhã e durava aproximadamente (doze) horas por dia, as doenças contraídas com as más condições de trabalho eram inúmeras, inclusive fungos, o que não poderia ser empecilho para realizar o trabalho. Não havia médicos na propriedade, e pela compra de remédios era cobrado valores exorbitantes. ${ }^{11}$

Havia proibição em sair do local de trabalho, e ameaças de morte caso isto acontecesse. Os trabalhadores viviam com medo e aflições diárias, onde percebe-se claramente inclusive, no testemunho das pessoas que foram resgatadas naquela fazenda:

\footnotetext{
Na fazenda a gente passa muita fome, e os peões vivem muito humilhados. Tantas vezes eu vi [o gerente] prometendo tiros aos peões. E a situação continua. se querem sair em paz, precisam fugir. Estes dias saíram sete, fugidos sem [receber] dinheiro Chegou um rapaz do Pará prometendo boas condições de trabalho para a gente. Chegou lá e não era o que ele prometeu. Somos jogados no galpão, tinha que trabalhar doente, com febre, tinha jeito não. Passamos fome, muita fome. "Só quem passou sabe o que aconteceu

[...] é desumano que que fizeram com a gente. Não é humano

[...] desse tempo para cá não viajo mais, fiquei com medo.

[...]Todo mundo pensou que não voltava de lá. E aí a gente voltou e quando cheguei foi uma alegria estar na minha terra e na minha casa.

[...] A gente foi para debaixo de um barraco de lona. (FERREIRA, 2016).
}

\footnotetext{
${ }^{10} \mathrm{O}$ salário que receberiam seria de 10 reais por "alqueire de juquira roçada" (FERREIRA, 2016).

${ }^{11}$ Segundo eles, um antibiótico chegava a custar cerca de R\$3.000,00 (Três mil reais) (Ferreira, 2016).
} 
O percorrer da história se dá cronologicamente da seguinte forma: Em Dezembro de 1988, a Comissão Pastoral da terra (CPT), apresentaram uma denúncia ${ }^{12}$ perante a Polícia Federal pelo desaparecimento de duas pessoas na fazenda bem como pela prática de trabalho escravo. As denúncias foram inúmeras, dentre elas, merece destaque o do Sr. Adailton Martins dos Reis, que trabalhava na Fazenda, segundo ele:

\begin{abstract}
Trabalhei na fazenda 30 dias, aqui o [gato] me garantiu muitas coisas e eu levei todos os mantimentos para o trabalho e chegando lá ele me jogou numa lama, roçando juquira, morando num barraco cheio de água, minha esposa operada, minhas crianças adoeceram, era o maior sofrimento. Precisei comprar dois vidros de remédios e me cobraram $\mathrm{Cz} \$ 3.000,00$. Quando fui sair da fazenda, fui acertar a conta, ainda fiquei devendo Cz\$21.500 e aí precisei vender 1 rede, 1 colcha, 2 machados, 2 panelas, pratos, 2 colheres [...] e ainda fiquei devendo Cz\$16.800 e saí devendo. [...] Durante todo este tempo não peguei nada de dinheiro. [...] Quando queria vir embora, ele não me ofereceu condição pra sair, eu fiquei a manhã inteira levando chuva, pois o gerente Nelson nos deixou na beira da estrada na chuva, com [minha] mulher e filhos doentes. $\mathrm{Na}$ fazenda a gente passa muita fome e os peões vivem muito humilhado[s], tantas vezes eu o vi prometendo tiros para os peões. E a situação continua, os peões só querem sair em paz, precisam fugir, estes dias saíram 7 fugidos sem dinheiro. (REIS, 2008).
\end{abstract}

Em 27 de Dezembro de 1988, a CPT, enviou uma carta a Conselho de Defesa dos Direitos da Pessoa Humana (CDDPH) requerendo que fosse reforçada a fiscalização da Fazenda Brasil Verde, afirmando que já havia sido oferecido a denúncia.

Em 20 de Fevereiro de 1989 houve uma visita da Polícia Federal na respectiva fazenda que em seu relatório afirmou não haver vestígios suficientes para configuração de trabalho escravo.

Posteriormente em 1992, a CTP novamente tenta solucionar a questão e encaminha a PGR um ofício relatando a denúncia feita a PF e em dezembro de 1988 e perante o Conselho de Defesa dos Direitos da Pessoa Humana, em janeiro de 1989. A denúncia foi protocolizada em 22 de abril de 1992 e a PGR instaurou um processo administrativo.

Em 4 de junho de 1992 e 22 de setembro de 1992 requereu ao Departamento de Polícia Federal informação sobre p caso. Assim em 7 de dezembro de 1992, o Coordenador Central do Departamento de Polícia Federal informou sobre as diligências realizadas na Fazenda Brasil

\footnotetext{
${ }^{12}$ A CPT estava acompanhada de José Teodoro da Silva e Miguel Ferreira da Cruz, respectivamente, pai e irmão de lron Canuto da Silva, de 17 anos, e de Luis Ferreira da Cruz, de 16 anos. Segundo eles, os jovens ao tentarem deixar a fazenda foram coagidos a retornarem e posteriormente desapareceram. (FERREIRA, 2016).
} 
Verde em 1989, afirmando que não havia sido constatada a presença de trabalho escravo. Em agosto de 1993, a Delegacia Regional do Trabalho DRT após realizar visita a fazenda, confirma a mesma informação da PF.

Em abril de 1994, a PGR afirma que as investigações da Polícia Federal não foram suficientes, uma vez que, sequer registaram por escrito as declarações dos trabalhadores, bem como outras inconsistências, como: lista com nome dos trabalhadores, qualificação, se havia armas na propriedade dentre outros.

Em março 1996, o Ministério do Trabalho, realizando uma vista na fazenda, descobre irregularidades.

Em 1997, dois trabalhadores da fazenda, prestaram declaração a PF relatando as condições e que viviam na FBV, como as investidas ameaças de morte caso abandonasse a fazenda. Desta forma, neste mesmo ano houve uma nova visita no local pelo Ministério do Trabalho, que:

i) os trabalhadores se encontravam alojados em barracões cobertos de plástico e palha nos quais havia uma "total falta de higiene"; ii) vários trabalhadores eram portadores de doenças de pele, não recebiam atenção médica e a água que ingeriam não era apta para o consumo humano; iii) todos os trabalhadores haviam sofrido ameaças, inclusive com armas de fogo, e iv) declararam não poder sair da Fazenda. Além disso, comprovou a prática de esconder trabalhadores quando se realizam as fiscalizações. No momento da fiscalização foram encontradas 81 pessoas. "Aproximadamente 45 " dessas 81 pessoas não possuíam carteiras de trabalho (CTPS) e tiveram esse documento emitido naquele momento. (Corte Interamericana de Direitos Humanos, 2017).

Ato contínuo, o Ministério do Trabalho e o Ministério Público Federal, ofereceram denúncia contra os donos da fazenda. Na denúncia, o Ministério Público faz os seguintes relatos:

A "Fazenda Brasil Verde" costuma contratar trabalhadores rurais, "peões", para o corte da juquira mediante o aliciamento dos mesmos, como os 32 (trinta e dois) trabalhadores convidados [...] no município de Xinguara, por [...] um empreiteiro, in casu, o denunciado Raimundo Alves da Rocha, entre 24 de março e 14 de abril do presente ano [...] para trabalharem em outra localidade em troca de salário. Parte deste é adiantado antes de chegarem ao local de trabalho [...] Ao chegarem na fazenda, os trabalhadores são alojados em barracões cobertos de plástico e palha, sem proteção lateral [...] a água ingerida [...] não é própria para consumo humano, pois serve de local de banho e bebedouro para os animais da Fazenda [...] a alimentação, como a carne exposta aos insetos e intempéries, é fornecida [por um dos] denunciado[s] [...] sob o sistema de barracão e [...] intermediado pela Fazenda através do gerente [...] Antônio Alves Vieira. Vários trabalhadores [...] declararam que estarem proibidos de saírem da Fazenda enquanto houver débito sob pena de ameaça de morte [...] ao 
adquirirem os alimentos a preços exorbitantes [...] e por já iniciarem o trabalho com o débito proveniente do hotel [...] o irrisório salário que receberiam nunca seria suficiente para pagar suas dívidas. Enquanto isso, o proprietário da Fazenda lucra ao dispor de trabalhadores que não recebem qualquer salário pelo serviço prestado [...] [...] o único caminho de saída da Fazenda é limítrofe dos prédios do escritório e da casa do gerente, que não permite a saída dos trabalhadores [...] Relatório da visita à Fazenda Brasil Verde, Grupo Móvel de Trabalho, 23, 28 e 29 de abril de 1997 (expediente de prova, folhas 4629 a 4638). 132 Relatório da visita à Fazenda Brasil Verde, Grupo Móvel de Trabalho, 23, 28 e 29 de abril de 1997 (expediente de prova, folhas 4629 e 4630). 133 Relatório da visita à Fazenda Brasil Verde, Grupo Móvel de Trabalho, 23, 28 e 29 de abril de 1997 (expediente de prova, folha 4637). 134 Relatório da visita à Fazenda Brasil Verde, Grupo Móvel de Trabalho, 23, 28 e 29 de abril de 1997 (expediente de prova, folha 4637). Denúncia do Ministério Público Federal de 30 de junho de 1997 (expediente de prova, folhas 4623 e 4625 a 4628). Acrescente-se aos fatos, a apreensão pela fiscalização, de um pedido aviso prévio assinado por um trabalhador [...] e [foram encontradas] diversas notas promissórias em branco, apenas com as assinaturas dos trabalhadores. [...] em dezembro de 1996, foram constatadas as mesmas irregularidades pela fiscalização, assim como, em 1989, já havia notícias de crimes contra a organização do trabalho e redução à condição análoga à de escravo. Pela não apuração desse fato na época própria e a prescrição dos demais crimes, quando os fatos chegaram ao conhecimento do Ministério Público Federal, tornou-se impossível a proposição da ação penal [...] o proprietário da fazenda, terceiro denunciado, tinha plena consciência de que, no mínimo, estaria cometendo um delito de frustração de direitos trabalhistas, mediante fraude. (COMISSÃO, 2015).

Posteriormente tem-se várias tratativas. Em 1997 nova denúncia afirmando que a fazenda continua nas mesmas atitudes, em 1999 o dono da fazenda cumpriu a pena de doar sextas básicas.

Até 2001 o problema ${ }^{13}$ não havia sido solucionado. Assim em 4 de março de 2015 a Comissão Interamericana de Direitos humanos, ofereceu denúncia a Corte sobre o caso Trabalhadores da Fazenda Brasil Verde contra a República Federativa do Brasil.

Apenas em 2016, a CIDH condenou o Estado Brasileiro por não ter adotado medidas efetivas para impedir a submissão de seres humanos a esse tipo de prática, determinando a reabertura das investigações ${ }^{14}$ para processar e punir os responsáveis, além da indenização ${ }^{15}$ de todas as vítimas.

\footnotetext{
${ }^{13}$ Como ainda não havia sido consolidada a competência federal para investigar o crime de trabalho escravo, a Justiça Federal de Marabá que atuava no caso remeteu o processo à Justiça Estadual em Xinguara, no Pará. Depois disso, o inquérito desapareceu e não foi mais reinstaurado. (COMISSÃO, 2015).

${ }^{14}$ Inquérito policial 2001.39.01.000270-0. Foram 72 das cerca de 80 vítimas, atualmente residentes em 11 Estados (Piauí, Pará, São Paulo, Distrito Federal, Mato Grosso, Maranhão, Ceará, Goiás, Mato Grosso do Sul, Minas Gerais e Santa Catarina). (COMISSÃO, 2015).

15 As indenizações permearam 5 (cinco) milhões de dólares. (COMISSÃO, 2015).
} 
Veja-se, as manchas do problema se inicia em $1988^{16}$ e apenas em 2016 houve uma resposta efetiva ao caso, ou seja, 28 (vinte e oito) anos depois. Vale dizer que essa efetividade se deu através da sentença da CIDH, e não pelo Brasil.

Importante empresa espanhola também é flagrada com trabalho escravo. Nesse sentido é a reportagem do Portal Carta Maior:

Em operações realizadas em maio e junho por fiscais do Ministério do Trabalho e Emprego (MTE), três oficinas de costura que fabricavam peças de roupas para a Zara foram flagradas mantendo trabalhadores em situação análoga à escravidão.

Ao todo, 67 trabalhadores foram liberados, entre eles ao menos 14 bolivianos e um peruano. Os fiscais flagraram irregularidades no registro em carteira e nos pagamentos, falta de condições de higiene e segurança nas oficinas, jornadas de até 14 horas e até cerceamento de liberdade. O caso chegou a derrubar as ações da empresa na Bolsa de Madri.

Em sua defesa, a companhia espanhola tem alegado que não sabia do problema, o qual só teria ocorrido porque um de seus fornecedores diretos - a AHA Ind. Com. Roupas - realizou "terceirização não autorizada" ao contratar as oficinas flagradas com trabalhadores escravos. [...] (CARTA, 2011).

Assim, conclui-se diante dos casos expostos, que tanto no Brasil como na Espanha, há situação de pessoas que sofrem com a violação de seus direitos através do trabalho escravo.

\section{Conclusão}

Consoante afirmado o ordenamento jurídico tem sua base no Princípio da Dignidade da pessoa humana. O Direito do trabalho, enquanto direito social fundamental para o acesso a capacidade de prover suas necessidades e de sua família, é então a maneira de se atender direitos e necessidades decorrentes desse atributo, que é inerente ao ser humano: a Dignidade.

O inicio da escravidão atual começa pelas decisões arbitrarias de um poder estatal fraco que não dirimi os conflitos internos de seu povo, que afirma lutar pelos direitos humanos através de políticas públicas ou de conscientização, mas que retira do próprio povo a sua integridade de viver em um ambiente que respeite seus direitos deliberados constitucionalmente ${ }^{17}$.

Embora a lei proíba expressamente o trabalho escravo, ele ainda existe, entretanto, descaracterizado, tem forma de legal, mas muitos não sabem o eco da dor que causa. Pessoas iludidas por melhores condições de vida são aliciadas, algumas tem a vida ceifada, seja pelo

\footnotetext{
${ }^{16}$ Não se sabe o quanto tempo esta propriedade praticou a modalidade de trabalho escravo. Em 1988 foram as primeiras aparições de vestígios.

${ }^{17}$ Nota-se de forma clara a preocupação da CR/88 em seu texto constitucional, no que tange os Direitos Humanos.
} 
esgotamento físico ou emocional. São tratadas como "objetos", sim! Se tornam objetos dos seus senhores. É real, mas se disfarça. O sofrimento é disfarçado por grandes senhores de terra ou por grandes empresas, a fome é disfarçada por lavagem de comida, o sono se disfarça por dormir ao relento, mas a vergonha e o medo em nada se disfarçam, muito menos a responsabilidade por lutar pelo menos ouvidos.

A escravidão contemporânea se diferencia da escravidão de tempos passados pois não decorre de guerra ou sequestro, mas camuflada por oportunidade e esperança.

É inaceitável a aquiescência do trabalho em condições análogas a de escravo, seja por cerceamento da liberdade, situação degradante ou por qualquer motivo que não respeite as condições e necessidades mínimas da pessoa, atingindo os Direitos e Dignidade do ser humano. A submissão da pessoa a trabalho escravo importa na destituição de sua dignidade enquanto ser humano e não, tao somente o cerceamente de seus direitos trabalhistas

De acordo com este entendimento, conclui-se que o trabalho em situação análoga a de escravo fere a dignidade da pessoa humana.

Em que pese tamanha dificuldade de enfrentamento ao combate de trabalho escravo, vários são os Órgãos que podem ser úteis à sua repressão, a saber: O Ministério do Trabalho, Ministério Público do Trabalho e Emprego (MTE), o Grupo Especial de Fiscalização Móvel, o Programa Lista Suja no Brasil, dentre outros.

Merece destaque ainda algumas ONGs, quais sejam: ONG repórter Brasil, Comissão pastora da Terra e entidades sindicais. No meio acadêmico, há a Clínica de Trabalho Escravo da Universidade Federal de Minas Gerais.

Nesta seara, necessário a ampliação de políticas públicas para controle e aplicação real da Lei. O combate ao trabalho escravo é de responsabilidade da sociedade e do Poder Público. Somente assim, será vencida a luta contra a escravidão.

\section{Referências bibliográficas}

ASI - ANTI-SLAVERY INTERNATIONAL. Formas contemporâneas de escravidão. In: Trabalho escravo no Brasil contemporâneo. Goiânia/São Paulo: CPT/Loyola, 1999. p.49-70.

BRASIL. Congresso Nacional. Constituição da República Federativa do Brasil de 05 de outubro de 1988. Disponível em:

$<$ http://www.planalto.gov.br/ccivil_03/constituicao/constituicao.htm>. Acesso em: 06 maio 2018 . 
BRASIL. Congresso Nacional. Lei n.3.353 de 13 de Maio de 1888. Disponível em: $<$ http://www.planalto.gov.br/ccivil_03/leis/lim/lim3353.htm>. Acesso em: 06 maio 2018.

BRASIL. Congresso Nacional. Decreto Lei n. 5.452 de 01 de Maio de 1943. Disponível em: $<$ http://www.planalto.gov.br/ccivil_03/decreto-lei/Del5452.htm>. Acesso em: 07 maio 2018.

BRASIL. Congresso Nacional. Decreto Lei n. 2.848 de 07 de Dezembro de 1940.

Disponível em: < http://www.planalto.gov.br/ccivil_03/decreto-lei/Del2848compilado.htm>. Acesso em: 07 maio 2018.

BRASIL. Manual de Combate ao Trabalho em Condições Análogas às de Escravo. Manual de Combate ao Trabalho em Condições análogas às de escravo Brasília: MTE, 2011.

BRASIL. Congresso Nacional. Decreto n. ${ }^{\circ}$ 58.563/1966. Convenção das Nações Unidas sobre Escravatura de 1926. Disponível em: < http://www2.camara.leg.br/legin/fed/decret/ 1960-1969/decreto-58563-1-junho-1966-399220-publicacaooriginal-1-pe.html>. Acesso em: 06 maio 2018.

BRITO FILHO, José Cláudio Monteiro de. Trabalho Escravo: caracterização jurídica. São Paulo: LTr, 2014. Disponível em: < https://www.cartamaior.com.br/?/Editoria/DireitosHumanos/Flagrada-com-trabalho-escravo-Zara-agora-diz-que-ampliara-monitoramento-defornecedores/5/17682>. Acesso em: 06 maio 2018.

CARTA Maior. Flagrada com trabalho escravo, Zara agora diz que ampliará monitoramento de fornecedores. S.L.2011.

CESÁRIO, João Humberto. Legalidade e Conveniência do Cadastro de Empregadores que tenham mantido trabalhadores em condições análogas à de escravo compreendendo a "lista suja”. In: Suplemento Trabalhista - São Paulo - 2006.

COMISSÃO Interamericana de Direitos Humanos. Caso Trabalhadores da Fazenda Brasil Verde Vs. Brasil. Exceções Preliminares, Mérito, Reparações e Custas. Sentença de 20 de outubro de 2016, Série C No 318, par. 304. 
COSTA, Patrícia Trindade Maranhão. A Construção da Masculinidade e a Banalidade do Mal: Outros Aspectos do Trabalho Escravo Contemporâneo. Campinas, Cadernos Pagu (31), 2008.

DELGADO, Maurício Godinho. Princípios de direito individual e coletivo do trabalho. São Paulo: LTr, 2001.

ESTERCI, N. A dívida que escraviza. In: Trabalho escravo no Brasil contemporâneo. Goiânia/São Paulo: CPT/Loyola, 1999. p.101-126.

FERREIRA, José Pereira. Escravidão: uma história real. Youtube. 2016. Disponível em: $<$ https://m.youtube.com/watch?v=WzTi_vN6osg $>$. Acesso em: 13 maio 2018

FIGUEIRA, Ricardo Rezende. Pisando fora da própria sombra: a escravidão por dívida no Brasil contemporâneo. Rio de Janeiro: Civilização Brasileira, 2004

FIGUEIRA, Ricardo Rezende. Conceito Jurídico e Combate ao Trabalho Escravo Contemporâneo. São Paulo: Ltr, 2008.

FIGUEIRA, Ricardo Rezende. Trabalho Escravo Contemporâneo - um Debate Transdisciplinar. Rio de Janeiro. Mauad x. 2011.

FOLHA Online. 250 mil imigrantes trabalham como escravos na Espanha, revela ONG. São Paulo. 2002. Disponível em: $<$ http://www1.folha.uol.com.br/folha/dimenstein/imprescindivel/dia/gd101202.htm\#1>. Acesso em: 13 maio 2018.

MALHEIRO, Agostinho Marques Perdigão. A escravidão no Brasil: ensaio históricojurídico-social. Rio de Janeiro. Tipografia Nacional. 1850.

MARTINS, J. de S. A escravidão nos dias de hoje e as ciladas da interpretação. In: VV.AA. (org.). Trabalho escravo no Brasil contemporâneo. Goiânia/São Paulo: CPT/Loyola, 1999. p.127-164. 
MELTZER, Milton. História Ilustrada da Escravidão. Rio de Janeiro. Ediouro. 2004.

NOVAIS. Fernando A. História da Vida Privada no Brasil. Companhia das Letras. 1997.

ORGANIZAÇÃO Internacional do Trabalho (OIT). Perfil dos principais atores envolvidos no trabalho escravo rural no Brasil. Brasília. OIT. 2011.

PÁDUA, E. M. M. de. Metodologia científica: abordagem teórico-prática. 10. ed. ver. atual. Campinas, SP: Papirus, 2004.

QUEIROZ, Suely Roldes Reis. Escravidão negra no Brasil. Porto Alegre. Ática. 1993.

RTP Notícias. PJ desmantelou rede de trabalho escravo em Espanha. Portugal. 2008.

Disponível em: < https://www.rtp.pt/noticias/pais/pj-desmantelou-rede-de-trabalho-escravoem-espanha_n61003>. Acesso em: 13 maio 2018.

REIS, Adailton Martins dos. Escravidão: uma história real. Youtube. 2016. Disponível em: $<$ https://m.youtube.com/watch?v=WzTi_vN6osg $>$. Acesso em: 13 maio 2018

SCHWARCZ, Lilia \& STARLING, Heloisa. Brasil: uma biografia. São Paulo: Companhia das Letras, 2015.

SÊNECA, L. A. Sobre a brevidade da vida. Tradução de Lúcia Sá Rebello, Ellen Itanajara Neves Vranas e Gabriel Nocchi Macedo. Porto Alegre:RS. L\&PM. 2012. p. 7,8.

SENTO-SÉ, Jairo Lins de Albuquerque. Trabalho escravo no Brasil na atualidade. São Paulo, LTr, 2000.

VELLOSO, Gabriel; FAVA, Marcos Neves (coords.). Trabalho escravo contemporâneo: o desafio de superar a negação. São Paulo: ANAMATRA/ LTr, 2006. p. 65.

VILLANUEVA, Enrique López. Mudanças nas leis revela 5.600 casos de escravidão na Espanha. El País. Madri. 2017. Disponível em: 
$<$ https://brasil.elpais.com/brasil/2017/04/14/internacional/1492152357_266303.html >. Acesso em: 06 maio 2017. 


\section{DIREITO DO TRABALHO E EFICÁCIA DOS DIREITOS FUNDAMENTAIS NO MEIO AMBIENTE DO TRABALHO}

\section{APRESENTAÇÃO}

Esta publicação contempla os artigos científicos defendidos no VIII Encontro Nacional do CONPEDI (Conselho Nacional de Pesquisa e Pós-Graduação em Direito), ocorrido em Zaragoza - Espanha, no Grupo de Trabalho (GT) Direito do Trabalho e Eficácia dos Direitos Fundamentais no Meio ambiente do Trabalho, na tarde do dia 7 de setembro de 2018, e que foi coordenado pelas Professoras Doutoras Luciana Aboim Machado Gonçalves da Silva e Maria Aurea Baroni Cecato, e pelo Professor Doutor José Claudio Monteiro de Brito Filho.

São dez artigos, todos relacionados ao tema geral do Grupo de Trabalho, e que tratam de questões variadas. Parte significativa deles deve ser registrada de imediato: A incidência do ISS em regime de teletrabalho; O teletrabalho sob a nova ótica regulatória - desafios e adaptações da modalidade inserida no mundo do trabalho; O contrato intermitente e o tempo morto de trabalho; Modernização e flexibilização das leis trabalhistas: teletrabalho e o trabalho intermitente; A tarifação do dano extrapatrimonial no âmbito do Direito do Trabalho como forma de intervenção do Estado na relação entre particulares: análise de sua constitucionalidade; e Necessidade de proteção da saúde dos trabalhadores frente à precarização das condições de trabalho, porque estão diretamente relacionados a institutos normatizados pela nova regulamentação das relações entre trabalhadores e empregadores produzida no Brasil, principalmente sob a égide da Lei n. 13.467, de 2017, também conhecida como "reforma trabalhista", o que revela a atualidade das discussões.

Mas não é somente essa a matéria discutida, ainda que, pela sua atualidade, tal pudesse ser entendido como suficiente a justificar a publicação. O primeiro texto da publicação: A eficácia dos direitos fundamentais no meio ambiente do trabalho relaciona-se diretamente ao segundo aspecto da temática geral do GT e discute matéria que, no Brasil, desafia a noção geral do Direito Ambiental, pelo caráter patrimonialista com que ainda são reguladas as questões relacionadas à saúde e à segurança do trabalhador.

Por fim, em relação aos Direitos Fundamentais do trabalhador, nesse caso com uma defesa de sua prioridade ainda para o futuro, temos o texto Trabalho decente e o futuro do trabalho, e, 
desdobrando essa questão para aspectos mais específicos, dois artigos: O dumping social e a precarização global das relações de trabalho; e Repensando o conceito do trabalho escravo contemporâneo para a sua erradicação na realidade laboral brasileira.

É um conjunto poderoso de contribuições para a evolução do Direito do Trabalho, em especial dos Direitos Fundamentais em matéria de trabalho, fazendo jus ao esforço e à competência de seus autores, e justificando sua divulgação e leitura.

Coordenadores do GT:

Profa. Dra. Luciana Aboim Machado Gonçalves da Silva - UFS

Profa. Dra. Maria Aurea Baroni Cecato - UNIPÊ

Profa. Dra. José Claudio Monteiro de Brito Filho - UFPA / CESUPA 


\title{
A EFICÁCIA DOS DIREITOS FUNDAMENTAIS NO MEIO AMBIENTE DO TRABALHO
}

\author{
Deilton Ribeiro Brasil \\ Universidade de Itaúna (UIT) \\ Marco Antônio de Souza \\ Universidade de Itaúna (UIT)
}

\section{Resumo}

Esta pesquisa tem como objetivo demonstrar que o meio ambiente de trabalho integra o sistema de proteção ambiental da Constituição Federal de 1988 devendo ser considerado em sua eficácia, ou seja, como um direito fundamental. Da mesma forma que todo cidadão tem direito a um meio ambiente equilibrado, essencial a sua qualidade de vida, todo trabalhador tem direito a receber a proteção jurídica a um meio ambiente laboral seguro e saudável. A pesquisa é de natureza teórico-bibliográfica seguindo o método descritivo-dedutivo que instruiu a análise da legislação, bem como a doutrina que informa os conceitos de ordem dogmática

Palavras-chave: Direitos fundamentais, Meio ambiente do trabalho, Constituição Federal de 1988, Eficácia.

\begin{abstract}
Resumen/Résumé
This research aims to achieve that the labor environment integrates the system of environmental protection of the Federal Constitution of 1988 and must be considered in its effectiveness, that is, as a fundamental right. Just as every citizen has the right to a balanced environment, essential to their quality of life, every worker has the right to receive legal protection in a safe and healthy labor environment. It's a theoretical-bibliographical-natured research guided by descriptivedeductive method which had instructed the analysis of legislation, as well as the doctrine that informs the concepts of dogmatic order.
\end{abstract}

Keywords/Palabras-claves/Mots-clés: Fundamental rights, Labor environment, Federal Constitution of 1988, Effectiveness. 


\section{Introdução}

O presente artigo versa sobre a eficácia dos direitos fundamentais no meio ambiente do trabalho e tem por objetivo contribuir para a concretude desses direitos, com ênfase no ambiente laboral. O direito em sua dupla função em que serve de controle e de instrumento de transformação social mostra a difícil tarefa de harmonizar as relações sociais que estão em constante conflito de interesses.

$\mathrm{O}$ ensaio é dividido em quatro partes. A primeira parte é referente à introdução. $\mathrm{O}$ segundo tópico aborda sobre as conexões dos direitos fundamentais no meio ambiente do trabalho ressaltando a caracterização e a proteção difusa do meio ambiente de trabalho bem como temáticas relacionadas à globalização, flexibilização das normas trabalhistas e a desconstitucionalização do direito do trabalho sempre com o viés na proteção do meio ambiente laboral. Na terceira parte destaca a importância da dignidade da pessoa humana como núcleo essencial dos direitos fundamentais do artigo $5^{\circ}$, parágrafo 10 da Constituição Federal de 1988. Na última parte, são apresentadas as considerações finais.

O meio ambiente do trabalho pode ser definido como o lugar em que as pessoas desempenham suas atividades laborais, sejam remuneradas ou não, cujo equilíbrio está baseado na salubridade do meio e na ausência de agentes que comprometam a incolumidade físicopsíquica dos trabalhadores. Assim, não está restrito apenas ao local físico de trabalho do trabalhador, abrangendo, além do local de trabalho propriamente dito, os instrumentos utilizados para o trabalho, o modo que as tarefas são executadas e a maneira como o trabalho é tratado pelo empregador e pelos seus colegas de trabalho (MELO, 2013, p. 19).

Dessa forma, é necessário destacar que o meio ambiente do trabalho é parte integrante do conceito geral de meio ambiente. É espécie, sendo o meio ambiente o gênero. Sendo o meio ambiente ligado à satisfatória qualidade de vida, pode-se dizer que o meio ambiente do trabalho é um sub-ramo do direito ambiental que estuda a qualidade de vida e saúde das pessoas que trabalham. O legislador constitucional optou por fazer esta proteção de uma forma mais geral e outra mais específica. Em outras palavras, quando o artigo $225, \S 1^{\circ}$ e $4^{\circ}$ da Constituição Federal de 1988 prevê a proteção ambiental, ela protege o meio ambiente como um todo, nas suas mais diversas formas. No entanto a legislação infraconstitucional protege de uma maneira mais específica o meio ambiente do trabalho.

O reconhecimento da dignidade da pessoa humana consolidou-se pela Declaração Universal dos Direitos Humanos de 1948. A Constituição Brasileira de 1988 elevou-o a princípio estruturante do ordenamento jurídico pátrio. Não se pode falar em vida digna quando 
se labora em um meio ambiente de trabalho lesivo em detrimento da garantia constitucional do ambiente do trabalho ecologicamente equilibrado que tem por finalidade tutelar a vida humana. A eficácia de um ambiente de trabalho propício à saúde e segurança do trabalhador compete às empresas e ao Estado, seja através de uma legislação eficaz ou através de medidas de higiene e segurança eficientes no âmbito do trabalho.

O método utilizado para a realização do trabalho foi descritivo-analítico com a abordagem de categorias consideradas fundamentais para o desenvolvimento do tema sobre a eficácia dos direitos fundamentais no meio ambiente do trabalho. Os procedimentos técnicos utilizados na pesquisa para coleta de dados foram a pesquisa bibliográfica, a doutrinária e a documental. O levantamento bibliográfico forneceu as bases teóricas e doutrinárias a partir de livros e textos de autores de referência, tanto nacionais como estrangeiros. Enquanto o enquadramento bibliográfico utiliza-se da fundamentação dos autores sobre um assunto, o documental articula materiais que não receberam ainda um devido tratamento analítico. A fonte primeira da pesquisa é a bibliográfica que instruiu a análise da legislação constitucional e a infraconstitucional, bem como a doutrina que informa os conceitos de ordem dogmática.

\section{Conexões dos direitos fundamentais no meio ambiente do trabalho}

A Declaração Universal dos Direitos Humanos de 1948, em relação aos direitos dos trabalhadores, determina no artigo 23 que todo ser humano tem direito ao trabalho, à livre escolha de emprego, a condições justas e favoráveis de trabalho e à proteção contra o desemprego; todo ser humano, sem qualquer distinção, tem direito a igual remuneração por igual trabalho; e, ainda, que todo ser humano que trabalhe tem direito a uma remuneração justa e satisfatória, que lhe assegure, assim como à sua família, uma existência compatível com a dignidade humana, e a que se acrescentarão, se necessário, outros meios de proteção social; e, finalmente, que todo ser humano tem direito a organizar sindicatos e neles ingressar para proteção de seus interesses.

Com relação aos direitos humanos do trabalhador há que se destacar, ainda, a Convenção Americana de Direitos Humanos, também denominada Pacto de San José da Costa Rica, instrumento de maior importância no sistema interamericano. Foi assinada em San José, Costa Rica, em 1969, entrando em vigor em 1978 (PIOVESAN, 2016, p. 347-348).

Bobbio (2004, p. 77) sustenta a fundamentação jurídica do Direito do Trabalho como um todo, destacando ter sido inequívoco o elevar deste direito à categoria de direito fundamental, face ao surgimento das organizações de operários nas sociedades dos países em 
que primeiro ocorreu a revolução industrial, uma vez que, para o autor, sempre existiu a conexão entre mudança social e mudança na teoria e na prática dos direitos fundamentais, tendo o nascimento dos direitos sociais tornado esta conexão apenas mais evidente.

Dessa forma, o meio ambiente é qualificado como um direito fundamental de terceira geração, que são os direitos de solidariedade e fraternidade, como a paz no mundo, o desenvolvimento econômico dos países, a preservação do meio ambiente, do patrimônio comum da humanidade e da comunicação, os quais são imprescindíveis à condição humana e merecem a proteção do Estado e da sociedade em geral. Para conhecimento, os direitos de primeira geração são os direitos civis e políticos. Os direitos de segunda geração são os sociais, econômicos e culturais, os quais servem para dotar o ser humano das condições materiais necessárias ao exercício de uma vida digna (PEREIRA, 2016, p. 182).

Por sociedade fraterna, entende-se como um tipo de sociedade construída por "pessoas humanas estimuladas a perceber o sentido da própria existência e porque percebem o sentido da própria existência e, adotam modos de vida que dão sentido à existência do Humano e a sua continuidade no tempo e espaço da biosfera" (SILVA; BRANDÃO, 2015, p. 151).

A perspectiva da construção de uma sociedade fraterna global, pela concepção de um espaço público mundial, a partir de um projeto cultural que tenha por fundamento o sentido da existência do humano traz um grande e novo desafio à humanidade, que na organização da própria convivência terá que, antes de priorizar a reivindicação do caráter funcional, deverá priorizar a reivindicação do caráter humano, na qual o humano é o "sentido relacional de pensar e agir da pessoa humana" (SILVA; BRANDÃO, 2015, p. 151).

A estrutura basilar do direito ao meio ambiente do trabalho equilibrado decorre do direito fundamental ao meio ambiente, reconhecido pela Constituição da República Federativa do Brasil de 1988, em seu artigo 225, como direito fundamental, necessário, assim, à concretização e consolidação da dignidade da pessoa humana do trabalhador. A tutela ambiental é essencial à existência humana, sem a qual inexiste tutela da dignidade da pessoa humana. $\mathrm{E}$ ainda, o direito fundamental ao meio ambiente do trabalho equilibrado emana da garantia do direito à saúde, destacando-se o artigo 200, VIII da Constituição Federal, que determina como atribuição do sistema único de saúde, em prol da concretização do direito à saúde, colaborar na proteção do meio ambiente, nele compreendido o do trabalho.

O meio ambiente do trabalho seguro constitui direito fundamental dos trabalhadores. As normas a eles aplicáveis são dotadas de cogência absoluta e asseguram aos trabalhadores direitos indisponíveis, ante o caráter social que revestem e o interesse público que as inspira. Não podem sofrer derrogação nem mesmo pela derrogação nem mesmo pela via negocial 
coletiva. $\mathrm{O}$ interesse público está presente quando se trata de meio ambiente do trabalho, cujo alcance ultrapassa o interesse meramente individual de cada trabalhador envolvido, embora seja ele o destinatário imediato da aplicação da norma (ROMITA, 2005, p. 386).

A Constituição Federal de 1988 no que tange aos direitos fundamentais dogmatizados tem aplicação imediata, ou seja, leis infraconstitucionais vigentes anteriormente a promulgação do novo texto constitucional que contenham norma que afronte ou que respalde atitudes que vão de encontro com os novos dogmas, não são recepcionadas e não terão aplicabilidade e validade (FAZOLLI, 2009, p. 61).

Deve-se destacar que o meio ambiente de trabalho engloba todo trabalhador que exerce uma atividade, remunerada ou não, e porque todos estão amparados constitucionalmente de um ambiente de trabalho adequado e seguro, necessário à digna e sadia qualidade de vida (PEREIRA, 2016, p. 181).

Há uma reciprocidade entre os direitos fundamentais, especialmente entre o direito à vida, à saúde e ao meio ambiente saudável e equilibrado. Não se pode viver qualitativamente sem que as condições sejam propícias, e somente quando atendidas tais condições poderão ser exercitados os demais direitos humanos, dentre eles os sociais, os políticos e os da personalidade do ser humano. $\mathrm{O}$ fenômeno da necessidade de proteção ao meio ambiente passou a ser considerado um conjunto de elementos interligados e de causação recíproca entre eles, e como tal, principiou a ser tratados nos direitos internos dos países (SOARES, 2001, p. 40).

\subsection{Caracterização do meio ambiente do trabalho}

O meio ambiente do trabalho encontra-se devidamente amparado pela Constituição da República Federativa do Brasil, especialmente pelo artigo $7^{\circ}$, que prescreve, como direito do trabalhador, a redução de riscos inerentes ao trabalho, por meio de normas de saúde, higiene e segurança (GURGEL, 2010), (HERMIDA, 2007).

O caput do artigo 170 da Constituição Federal apresenta o núcleo central da manutenção da ordem econômica no Brasil, que é a valorização do trabalho humano e digno. Logo a seguir, o inciso VI estabeleceu expressamente que a ordem econômica deve observar o princípio de defesa do meio ambiente.

Em outras palavras, o legislador constituinte de 1988 assegurou e incentivou a livre iniciativa econômica, desde que respeitados os princípios que norteiam a dignidade da pessoa humana, no caso, o respeito ao meio ambiente do trabalho como novo direito da personalidade (MELO, 2013, p. 35-36). 
Percebe-se que o meio ambiente do trabalho é um dos mais importantes aspectos do meio ambiente e que agora, pela primeira vez na história do sistema jurídico brasileiro, adquire proteção constitucional adequada, que precisa sair do papel para a prática diária, o que somente será possível mediante grande reformulação de entendimentos clássicos que sempre prestigiaram as formas indenizatórias como, por exemplo, o pagamento dos adicionais de insalubridade e de periculosidade (MELO, 2013, p. 37).

Neste contexto, o meio ambiente do trabalho está inserido no meio ambiente geral (artigo 200, VIII, da Constituição da República), de modo que é impossível alcançar qualidade de vida, sem ter qualidade de trabalho, nem se pode atingir meio ambiente equilibrado e sustentável ignorando o meio ambiente do trabalho (OLIVEIRA, 2011, p. 79).

Machado (2001, p. 91) entende o meio ambiente do trabalho como macrobem que protege a vida em todas as suas formas garante a todos o direito a viver em um ambiente que não ofereça risco a saúde e a vida, fato este que o destaca como direito fundamental.

Assim, o meio ambiente do trabalho é compreendido como o lugar onde o trabalhador exerce a sua profissão ou desenvolve o seu trabalho. A segurança e a higidez do ambiente de trabalho integram esse conceito, que abarca fatores de ordem física, química, biológica, mecânica, ergonômica e cultural (FARIA, 2007, p. 445).

Nascimento (1997, p. 583-587) acrescenta que o meio ambiente do trabalho são as edificações do estabelecimento, EPI, iluminação, conforto térmico, instalações elétricas, condições de salubridade ou insalubridade, de periculosidade ou não, meios de prevenção à fadiga, outras medidas de proteção ao trabalho, jornadas de trabalho e horas extras, intervalos, descansos, férias, movimentação, armazenagem e manuseio de materiais que formam o conjunto de condições de trabalho.

Existem três dimensões importantes que devem ser consideradas no que diz respeito ao meio ambiente do trabalho: o meio ambiente do trabalho stricto sensu, o meio ambiente de trabalho lato sensu e o meio ambiente de trabalho de terceiros. O meio ambiente de trabalho stricto sensu é o lugar onde, restrita e tradicionalmente, se exerce uma profissão, por exemplo, uma repartição pública, um estabelecimento comercial ou um setor de produção de uma indústria. O meio ambiente de trabalho lato sensu é o local onde se exerce a profissão, considerado da forma mais abrangente possível, como o pátio de uma fábrica, o quintal de uma loja ou o estacionamento de um órgão público, com relação a um funcionário que não trabalhe exatamente nessas localidades. Esse conceito engloba também o lugar onde estiver sendo desempenhada a atividade profissional no caso de um vendedor ou de um trabalhador ambulante, seja em uma praça pública, seja, em um automóvel, ou ainda a moradia, em se 
tratando do profissional que trabalha em casa. O meio ambiente de trabalho de terceiros é a consideração da possibilidade de um determinado ambiente de trabalho influenciar ou modificar as condições de um ambiente de trabalho alheio, por conta de suas externalidades. Um exemplo disso é o caso de uma fábrica que, ao contaminar um rio, prejudica, talvez até de forma definitiva, o meio ambiente do trabalho de agricultores, pecuaristas e pescadores da região (FARIA, 2007, p. 446-447).

Em outras palavras, é o local onde as pessoas desempenham suas atividades laborais, sejam remuneradas ou não, cujo equilíbrio está baseado na salubridade do meio e na ausência de agentes que comprometem a incolumidade físico-psíquica dos trabalhadores, independentemente de condição que ostentem homens ou mulheres, maiores ou menores de idade, celetistas, servidores públicos, autônomos etc. Caracteriza-se pelo complexo de bens imóveis ou móveis de uma empresa ou sociedade, objeto de direitos subjetivos privados e invioláveis da saúde e da integridade física dos trabalhadores que a frequentam (FIORILLO, 2012, p. 81-82).

O que se procura salvaguardar é o homem, enquanto ser vivo, das formas de degradação e poluição do meio ambiente onde exerce o seu trabalho, que é essencial à sua qualidade de vida, tratando-se de um direito difuso (NOGUEIRA, 2008, p. 26).

Dessa forma, o meio ambiente do trabalho relaciona-se com a preservação da integridade física e psicológica do trabalhador, compatibilizando os meios de produção com o equilíbrio ambiental interno aos locais onde se desenvolvem as atividades laborativas (BELFORT, 2008, p. 60).

\subsection{Proteção difusa do meio ambiente do trabalho}

O direito à preservação do meio ambiente (inclusive do trabalho) é de caráter difuso. A reparação do prejuízo causado pelo dano, todavia, não se esgota na indenizabilidade do dano causado ao ambiente propriamente dito, mas inclui a reparação do prejuízo infligido ao terceiro vitimado pelo mesmo fato. A verdade é que o simples caráter metaindividual que dá o perfil fundamental ao direito ambiental não exclui o reflexo do dano geral no patrimônio deste ou daquele indivíduo (SADY, 2000, p. 205).

A preservação do meio ambiente é apreciada como um interesse difuso, tendo em vista que o meio ambiente é um bem jurídico de interesse de todos. O patrimônio ambiental, sendo de toda a humanidade, é qualificado como res omnium, ou seja, coisa de todos. O meio ambiente do trabalho equilibrado é parte integrante, e extremamente importante, do meio ambiente 
considerado na sua totalidade, é um direito difuso, ou seja, aquele cujo conceito legal é de interesse transindividual, de natureza indivisível, nos quais os titulares são pessoas indeterminadas e ligadas por circunstâncias de fato. Esta informação está em harmonia com o disposto no artigo 81, inciso I, do Código de Defesa do Consumidor, instituído pela Lei $\mathrm{n}^{\circ}$ 8.078/90 (PEREIRA, 2016, p. 182).

O Código de Defesa do Consumidor aponta os direitos difusos, coletivos e homogêneos, em seu artigo 81, inciso I - interesses ou direitos difusos. Entendem-se como os direitos transindividuais, de natureza indivisível, cujos titulares sejam pessoas indeterminadas e ligadas por circunstâncias de fato; inciso II - interesses ou direitos coletivos. Entendem-se como os direitos transindividuais, de natureza indivisível de que seja titular o grupo, categoria ou classe de pessoas ligadas entre si ou com a parte contrária por uma relação jurídica base; e, por fim, o inciso III - interesses ou direitos homogêneos. Entendidos como os de origem comum (PEREIRA, 2016, p. 183).

O reconhecimento internacional do direito ao meio ambiente está expresso nos princípios da Declaração de Estocolmo, de 1972. Tais princípios, divulgados em Estocolmo, foram, ratificados, no Brasil, pela Declaração do Rio, realizada na Conferência das Nações Unidas sobre o meio Ambiente e Desenvolvimento, Rio-92 (PEREIRA, 2016, p. 183).

No âmbito internacional a Convenção da Organização Internacional do Trabalho ${ }^{\circ}$ 115 trata sobre proteção contra radiações ionizantes; a Convenção $\mathrm{n}^{\circ} 127$, que menciona o peso máximo das cargas; a Convenção $\mathrm{n}^{\circ} 136$, que dispõe sobre proteção contra os riscos ocasionados pelo benzeno; a Convenção $n^{\circ} 85$, que trata sobre prevenção e riscos profissionais provocados por substâncias cancerígenas no local de trabalho; a Convenção $n^{\circ}$ 148, que dispõe sobre proteção contra os riscos provenientes da contaminação do ar, de ruído, e de vibrações no local de trabalho; a Convenção $n^{0} 155$, que aponta a segurança e saúde dos trabalhadores e meio ambiente de trabalho e o Protocolo de 2002 a respeito do assunto; a Convenção $\mathrm{n}^{\mathrm{o}} 161$, que cita os serviços de saúde no trabalho; a Convenção $n^{\circ} 162$, que dispõe sobre a utilização do amianto com segurança; a Convenção $\mathrm{n}^{\circ}$ 170, que dispõe sobre a utilização de produtos químicos no trabalho (BARROS, 2005, p. 1005).

\subsection{Globalização, flexibilização das normas trabalhistas e a desconstitucionalização do direito do trabalho e proteção do meio ambiente laboral}

Quando se trata do meio ambiente do trabalho, a globalização econômica afeta diretamente os direitos sociais fundamentais individuais e coletivos: a automação é um dos 
principais efeitos dessa globalização ao meio ambiente do trabalho. Isso porque, ao mesmo tempo que traz as facilidades de consumo, ela elimina de forma progressiva postos de trabalho e modifica ambiente laboral. Dessa forma, a era da automação tecnológica, que redesenha as relações comerciais e políticas entre os Estados, é a mesma que também modifica os interesses coletivos e difusos específicos ao meio ambiente do trabalho, impõe desafios ao Direito quanto à proteção desse meio ambiente laboral (MORAIS, 2017, p. 400-404).

Por seu turno, o processo de flexibilização, ou um ajuste das normas jurídicas aplicáveis ao Direito do Trabalho, só é legítimo com a observação dos direitos e garantias fundamentais aplicáveis a todo cidadão seja ele trabalhador ou não, sob pena de estar ferindo norma de cunho legal e até mesmo podendo se tornar uma medida inconstitucional. Portanto, a flexibilização da legislação trabalhista não pode ferir nenhum princípio constitucional (PEREIRA; CARNEIRO, 2014, p. 8).

O papel do contrato de trabalho, tem na flexibilização das relações entre empregados e empregadores, com a revolução tecnológica, os avanços da microeletrônica e da telecomunicação no mundo que mudou, e as empresas foram forçadas a enfrentar uma feroz competição e o inovar tornou-se absolutamente essencial para ser vencido o desafio e gerar empregos, realizando várias mudanças na contratação individual e coletiva, todas orientadas pela flexibilização, simplificando o sistema previdenciário, reduzindo os encargos sociais, descentralizando as negociações, aumentando a produtividade do trabalho, subcontratando e terceirizando a mão de obra, vencendo a competição, elevando o nível do emprego, portanto, é a flexibilização que dará ao País as condições de competir e manter seu povo empregado (CARLI, 2005, p. 50).

Assim, a flexibilização é um fenômeno irreversível e o direito do trabalho deve aceitála para não obstar o desenvolvimento, com ela conviver, apesar dela promover melhorias no mercado de trabalho. Pela desregulamentação a taxa de desemprego pode ter aumento significativo, pois, sabemos que os fatores para seu surgimento são produzidos pela crise econômica, através das transformações tecnológicas e de melhor qualidade de vida (CARLI, 2005, p. 50).

Sem dúvida, a flexibilização preconizada pela doutrina neoliberal é uma técnica de retomada e reforço de poder, na medida em que a maior liberdade na escolha da forma de contratação, definição das condições de trabalho e dispensa do trabalhador que se pretende alcançar por meio da flexibilização equivale a um maior grau de poder (ALMEIDA; ALMEIDA, 2017, p. 130). 
Neste contexto, a desconstitucionalização do Direito do Trabalho é também uma técnica de retomada e reforço de poder, valendo anotar que, de acordo com a doutrina da destruição criativa, as crises fazem parte do processo de destruição por meio do qual o capitalismo evolui. A constituição do trabalho é um entrave a esta destruição e, portanto, evolução, o que justifica, na ótica neoliberal, a sua destruição (ALMEIDA; ALMEIDA, 2017, p. 130).

Essa desconstitucionalização do direito do trabalho pode assumir várias formas tais como a exclusão de regras e princípios de Direito do Trabalho da Constituição ou seja, a desconstrução da constituição do trabalho; o desrespeito às regras e princípios constitucionais do trabalho na ação administrativa, legislativa e judicial do Estado, no contexto das relações individuais e coletivas de trabalho e na análise e crítica doutrinária do Direito do Trabalho, ou seja, a ordinarização ou desnormatização da Constituição, no sentido do enfraquecimento da sua força normativa; e a produção, pelos entes representativos dos centros de poder econômicofinanceiro mundiais, de normas que desconsideram direitos e garantias constitucionalmente assegurados aos trabalhadores (ALMEIDA; ALMEIDA, 2017, p. 131).

Dessa forma, para se evitar o colapso dos direitos fundamentais é preciso que o Direito seja submetido a um profundo processo de revisão, em especial para que haja a proteção dos interesses coletivos e difusos inerentes à tutela do meio ambiente do trabalho (SANTOS, 2008, p. 430), (MORAIS, 2017, p. 405).

Por outras palavras, o Direito ante os desafios da globalização e flexibilização das leis trabalhistas não pode ser previamente determinado pelo interesse econômico e nem deve ser o garçom a servir aos seus interesses dos grupos ou elites privados em detrimento dos direitos das pessoas e dos interesses coletivos da sociedade (MORAIS, 2017, p. 406).

Antes, o Direito deve ser a garantia da proteção dos interesses coletivos e difusos da sociedade como um todo. Uma nova política do Direito como expressão da vontade coletiva, cuja regulação social se destine, em geral, à conservação de seu patrimônio imaterial da sociedade (cultura, bens e valores) e, em específico, se destine à tutela dos direitos relativos ao meio ambiente do trabalho (MORAIS, 2017, p. 406).

\section{A dignidade da pessoa humana como núcleo essencial dos direitos fundamentais do artigo $5^{\circ}$, parágrafo $1^{\circ}$ da Constituição Federal de 1988}

A assunção do indivíduo como protagonista do sistema produtivo, a sustentabilidade e o respeito ao meio ambiente constituem-se como novas condições para a viabilidade e até 
manutenção do capitalismo. Ainda incipiente nas relações trabalhistas, a superação da coisificação do homem, colocando-o como o cerne do direito, e, para tanto, a conservação da sua vida e da sua saúde e segurança no meio ambiente do trabalho foi corroborada pela Constituição da República Federativa do Brasil de 1988 (SALIBA; LOBATO, 2015, p. 138).

A dignidade da pessoa humana está devidamente assegurada no artigo $1^{\circ}$, inciso III, da Constituição Federal de 1988, constituindo, assim, um dos fundamentos da República Federativa do Brasil e do Estado Democrático de Direito. Essa leitura é complementada pelo disposto no artigo 170, caput e inciso VI, da Constituição Federal, o qual trata da ordem econômica e assegura a livre iniciativa, fundada na defesa do meio ambiente e na valorização do trabalho humano, de modo a assegurar a todos a existência digna, de acordo com os ditames da justiça social.

Dessa forma, fixa de maneira clara não só sua existência no plano constitucional do Direito Ambiental brasileiro, como também estabelece os critérios fundamentais destinados à sua interpretação e à adequada interpretação de uma política nacional do meio ambiente. A existência de um direito ao meio ambiente ecologicamente equilibrado pressupõe, assim, a obediência a alguns fundamentos específicos, um deles, que impõe de rigor, é que o Direito Ambiental brasileiro está vinculado à dignidade humana, ou seja, a pessoa humana é a verdadeira razão de ser do Direito Ambiental brasileiro. Além disso, não se pode olvidar que, para a vida humana existir, deve haver uma harmonia dela com o próprio ambiente. Estabelecese, portanto, um elo indissociável entre e o meio ambiente e o princípio da dignidade humana (LINHARES; PIEMONTE, 2010, p. 119).

Como um valor fundamental que é também um princípio constitucional, a dignidade humana funciona tanto como justificação moral quanto como fundamento jurídico-normativo dos direitos fundamentais. Sendo assim, ela vai necessariamente informar a interpretação de tais direitos constitucionais ajudando a definir o seu sentido nos casos concretos. Além disso, nos casos envolvendo lacunas no ordenamento jurídico, ambigüidades no direito, colisões entre direitos fundamentais e tensões entre direitos e metas coletivas, a dignidade humana pode ser uma bússola na busca da melhor solução. Mais ainda, qualquer lei que viole a dignidade, seja em abstrato ou em concreto, será nula (BARROSO, 2016, p. 64-66).

Melhor explicando, o princípio da dignidade humana é a qualidade intrínseca e distintiva reconhecida em cada ser humano que o faz merecedor do mesmo respeito e consideração por parte do Estado e da comunidade, implicando, neste sentido, um complexo de direitos e deveres fundamentais que assegurem a pessoa tanto contra todo e qualquer ato de cunho degradante e desumano, como venham a lhe garantir as condições existenciais mínimas 
para uma vida saudável, além de propiciar e promover sua participação ativa e co-responsável nos destinos da própria existência da vida em comunhão com os demais seres humanos (SARLET, 2008, p. 63).

O trabalho representa um valor político fundamental em termos de inclusão na ordem econômica de livre empresa, como garantia de coesão social e como forma de evitar a recusa política e global do sistema político e econômico capitalista. É realizado um intercâmbio entre o reconhecimento de direitos individuais e coletivos derivados do trabalho. O trabalho, por consequência, enquanto base da reprodução material e início da vida social para a maior 1941 ia dos homens e mulheres, é considerado uma atividade pessoal que abre espaço da economia onde se desenvolve, para o social e político. O trabalho, assim, não é um fato privado, mas um fenômeno social e político, e funda a legitimidade da Constituição em um sentido material, isto é, o funcionamento da vida em sociedade e seus equilíbrios de poder. Origina o compromisso progressivo entre a racionalidade do capital e a tutela do trabalho que se plasma no Estado social, e engendra as figuras sociais que representam e atuam em defesa de seus interesses tanto no espaço das relações de intercâmbio como no espaço do político-social, reconhecendo o conflito e a autonomia coletiva como eixos desta atuação (BAYLOS, 2013, p. 19-41), (ALMEIDA; ALMEIDA, 2017, p. 131).

Assim, a concretude da dignidade da pessoa humana, valor máximo e fundamental dos Direitos Fundamentais, apenas ocorrerá em uma sociedade considerada fraterna, em que há o respeito ao próximo e convivência harmônica para reger as relações entre os indivíduos. Em outras palavras, essa fraternidade deve ser compreendida como uma virtude da cidadania, que supera as fronteiras da pátria ou da nação (cidadania interna), numa perspectiva universal de pessoa humana (cidadania global), reivindicando o sentido da existência do humano e a sua continuidade no tempo e espaço (MACHADO, 2013, p. 79).

\section{Conclusões}

O trabalho é um direito fundamental que dignifica o homem permitindo-lhe sua inserção social e a aquisição de meios para prover a sua subsistência e de sua família. Está, ainda, intimamente relacionado ao próprio direito à vida já que muito mais que proteger o direito à vida, a Constituição garante o direito à vida digna e com qualidade. Nesse sentido o artigo 170 da Constituição Federal traduz os pilares sobre os quais se sustenta a ordem econômica, constituídos pela valorização do trabalho humano e a livre iniciativa, sendo assegurado a todos uma existência digna dentro do espírito de Justiça social. Ao assegurar 
existência digna, constituinte elege como princípio do inciso VI a defesa do meio ambiente na dimensão do trabalho. O meio ambiente é regido por princípios, diretrizes e objetivos específicos, sendo seu objeto maior a vida em todas as suas formas como valor fundamental (CAMILA, 2015, p. 412-413).

Há uma forte conexão entre os direitos fundamentais que os torna indivisíveis e impossibilita que se concretize, isoladamente, um deles, sem que se considere um todo, e a dignidade humana representa o corolário do cumprimento e concomitância de todos, e, para tanto, se faz essencial a harmonização do capital com o trabalho.

A indivisibilidade dos direitos fundamentais é expressa na própria Constituição Federal de 1988, que corrobora a importância do meio ambiente do trabalho, no artigo 200, inciso VIII, ao determinar como competência do sistema único de saúde, a colaboração na proteção do meio ambiente, nele compreendido o do trabalho.

$\mathrm{Na}$ mesma linha, a lei $\mathrm{n}^{\mathrm{o}} 6.938 / 81$, que versa sobre a Política Nacional de Meio Ambiente, inseriu o âmbito laboral dentro do conceito de meio ambiente, com o cunho de desenvolvimento sócio-econômico com proteção da dignidade da vida humana.

Em tempos de estratégia do mínimo (Estado, Direito do Trabalho e custos do trabalho mínimos), como parte da estratégia da máxima liberdade e do máximo poder (maximização da liberdade e poder do empregador e do capital), que conduz ao desemprego e ao subemprego de massa, à marginalização de amplos setores da população e à dominação da política econômica e social do Estado pelo mercado, é indispensável restabelecer o equilíbrio entre os interesses do capital e do trabalho, o que exige, principalmente, o respeito aos direitos fundamentais trabalhistas, específicos e inespecíficos (ALMEIDA; ALMEIDA, 2017, p. 180).

\section{Referências bibliográficas}

ALMEIDA, Cléber Lúcio de; ALMEIDA, Wânia Guimarães Rabêllo de. Direito do trabalho e constituição: a constitucionalização do direito do trabalho no Brasil. São Paulo: LTr, 2017, $191 \mathrm{p}$.

BARROS, Alice Monteiro de. Curso de direito do trabalho. São Paulo: LTr, 2005.

\section{BARROSO, Luís Roberto. A dignidade da pessoa humana no direito constitucional}

contemporâneo: a construção de um conceito jurídico à luz da jurisprudência mundial. Belo Horizonte: Editora Fórum, 2016, 132 p. 
BAYLOS, Antonio. La desconstitucionalización del trabajo en la reforma laboral del 2012. In: Revista de derecho social, ${ }^{0}$ 61, p. 19-41, 2013.

BELFORT, Fernando José Cunha. A responsabilidade do empregador na degradação do meio ambiente do trabalho e suas consequências jurídicas no âmbito do direito do trabalho. 2008, 206 f. Tese de Doutorado apresentada à PUC São Paulo. Disponível em: $<$ https://sapientia.pucsp.br/bitstream/handle/8194/1/Fernando\%20Jose\%20Cunha\%20Belfort. pdf $>$. Acesso em: 20 jan. 2018

BOBBIO, Norberto. A era dos direitos. Rio de Janeiro: Campus, 2004.

CAMILA, Adélia Procópio. Meio ambiente do trabalho como direito fundamental e responsabilidade civil do empregador. . In: Direito do trabalho e meio ambiente do Trabalho I [Recurso eletrônico on-line]. CONPEDI/UFMG/FUMEC/Dom Helder Câmara [Orgs.]; ANDRADE, Everaldo Gaspar Lopes de; CARVALHO NETO, Frederico da Costa; SCHWARZ, Rodrigo Garcia [Coords.] Florianópolis: CONPEDI, 2015.

CARLI, Vilma Maria Inocêncio. A flexibilização dos contratos de trabalho. Campinas-SP: ME, 2005.

FARIA, Talden Queiroz. Meio ambiente do trabalho. In: Direito e Liberdade, v. 6, $\mathrm{n}^{\mathrm{o}}$ 2, p. 443-462, jan./jun. 2007.

FAZOLLI, Silvio Alexandre. Bem jurídico ambiental: por uma tutela coletiva diferenciada. Porto Alegre: Verbo Jurídico, 2009, p. 61.

FIORILLO, Celso Antônio Pacheco. Curso de direito ambiental brasileiro. 4. ed. São Paulo: Saraiva, 2003.

FIORILlO, Celso Antonio Pacheco. Curso de direito ambiental brasileiro. 13 ed. revista atualizada e ampliada, São Paulo: Saraiva, 2012. 
GURGEL, Yara Maria Pereira. Direitos humanos, princípio da igualdade e não

discriminação: sua aplicação às relações de trabalho. São Paulo: LTr, 2010.

HERMIDA, Denis Domingues. As normas de proteção mínima e integridade física do trabalhador e a sua proteção nos direitos individual e coletivo do trabalho. São Paulo: LTr, 2007.

LINHARES, Mônica Tereza Mansur; PIEMONTE, Márcia Nogueira. Meio ambiente e educação ambiental à luz do princípio da dignidade da pessoa humana. In: Revista Veredas do Direito, Belo Horizonte, v. 7, nº 13/14, p. 101-124, jan.-dez. 2010.

MACHADO, Carlos Augusto Alcântara. A fraternidade e o direito constitucional brasileiro: anotações sobre a incidência e aplicabilidade do princípio/valor fraternidade no direito constitucional brasileiro a partir da sua referência no preâmbulo da Constituição federal de 1988. In: PIERRE, Luiz A. A. et al [Org.]. A fraternidade como categoria jurídica. São Paulo: Cidade Nova, 2013.

MACHADO, Sidnei. O direito à proteção ao meio ambiente de trabalho no Brasil: os desafios para a construção de uma racionalidade normativa. São Paulo. LTr, 2001. MELO, Raimundo Simão de. Direito ambiental do trabalho e a saúde do trabalhador: responsabilidades legais, dano material, dano moral, dano estético, indenização pela perda de uma chance, prescrição. 5 ed. São Paulo: LTr, 2013.

MORAIS, Océlio de Jesus Carneiro de. Proteção jurídica ao meio ambiente do trabalho saudável e seguro ante os desafios da globalização econômica. In: Revista Internacional Consinter de Direito, ano III, nº IV, Lisboa: Editorial Juruá, $1^{\circ}$ sem. 2017, p. 387-414.

NASCIMENTO, Amauri Mascaro. A defesa processual do meio ambiente do trabalho: dano, prevenção e proteção jurídica. In: Revista LTR, São Paulo, 63, maio, 1997, p.583-587.

NOGUEIRA, Sandro D’Amato. Meio ambiente do trabalho: o princípio da prevenção na vigilância e na saúde ambiental. São Paulo: LTr, 2008 
OLIVEIRA, Sebastião Geraldo de. Proteção jurídica à saúde do trabalhador. 6 ed. Editora: LTr, 2011.

PEREIRA, Marcela Semeghini. Meio ambiente de trabalho e os princípios do the triple botton line: a inevitabilidade de modernização da legislação para manutenção da ordem econômica. In: Revista da Faculdade de Direito-RFD, Rio de Janeiro, no 29, jun. 2016, p. 175-193. Disponível em: < http://www.epublicacoes.uerj.br/index.php/rfduerj/article/view/12221/16732>. Acesso em: 20 jan. 2018.

PEREIRA, Marcela Semeghini; CARNEIRO, Adeneele Garcia. A flexibilização da legislação trabalhista: os limites do trabalho aos domingos e feriados. In: Direito do Trabalho III. XXIII Congresso Nacional do Conpedi. João Pessoa: Paraíba, 2014, v. 1, p. 127-147. Disponível em: $<$ http://publicadireito.com.br/artigos/?cod=9b7edc4dfd8e15db $>$. Acesso em: 20 jan. 2018.

PIOVESAN, Flávia. Direitos humanos e o direito constitucional internacional. 16. ed. revista e atualizada. São Paulo: Saraiva, 2016.

ROMITA, Arion Sayão. Direitos fundamentais nas relações de trabalho. São Paulo: LTr, 2005.

SADY, João José. Direito do meio ambiente do trabalho. São Paulo. LTr, 2000.

SALIBA, Graciane Rafisa; LOBATO, Márcia Regina. Sustentabilidade e respeito ao meio ambiente do trabalho: a responsabilidade civil em prol da valorização humana e da repersonalização do direito do trabalho. In: Direito do trabalho e meio ambiente do Trabalho II [Recurso eletrônico on-line]. CONPEDI/UFMG/FUMEC/Dom Helder Câmara [Orgs.]; NASCIMENTO, Grasiele Augusta Ferreira; SILVA, Luciana Aboim Machado Gonçalves; CECATO, Maria Aurea Baroni [Coords.] Florianópolis: CONPEDI, 2015.

SANTOS, Boaventura de Sousa. A gramática do tempo: para uma nova cultura política. 2 ed. São Paulo: Cortex, 2008.

SARLET, Ingo Wolfgang. Dignidade da pessoa humana e direitos fundamentais na

Constituição Federal de 1988. 6 ed. Porto Alegre: Livraria do Advogado, 2008. 
SILVA, Ildete Regina Vale da; BRANDÃO, Paulo de Tarso. Constituição e fraternidade: o valor normativo do Preâmbulo da Constituição. Curitiba: Juruá, 2015.

SOARES, Guido Fernando Silva. Direito internacional do meio ambiente: emergência, obrigações e responsabilidade. São Paulo: Atlas, 2001. 


\title{
A INCIDÊNCIA DO ISS SOBRE OS SERVIÇOS PRESTADOS EM REGIME DE TELETRABALHO
}

\author{
Manoela De Bitencourt \\ Pontifícia Universidade Católica do Rio Grande do Sul
}

\begin{abstract}
Resumo
O presente trabalho tem por objetivo saber qual Município é competente para exigir o imposto sobre serviços do trabalhador que realiza a atividade em regime de teletrabalho. O teletrabalho é a possibilidade de prestar serviços de forma remota, à distância, por meio do uso da tecnologia da informação e da comunicação, isto é, por meio virtual. $\mathrm{O}$ art. $3^{\circ}$ da Lei Complementar 116 de 2003 prevê que o serviço considera-se prestado, e o imposto, devido, no local do estabelecimento prestador ou, na falta do estabelecimento, no local do domicílio do prestador. E o art. $4^{\circ}$ prevê que o estabelecimento prestador é o local onde o contribuinte desenvolva a atividade de prestar serviços, de modo permanente ou temporário, e que configure unidade econômica ou profissional. Nesse cenário, surge um conflito de competência municipal: qual Município é competente para tributar levando em consideração que o local da prestação de serviços é o ciberespaço. A pesquisa conclui por aquele Município em que se localiza o estabelecimento físico do titular do site ou e-mail, identificado nos registros mantidos pela Fundação de Amparo à Pesquisa do Estado de São Paulo.
\end{abstract}

Palavras-chave: Teletrabalho, Imposto sobre serviços, Competência municipal.

\begin{abstract}
Resumen/Résumé
The purpose of this study is to know which Municipality is competent to demand the tax on services of the worker who performs the activity in a teleworking regime. Teleworking is the possibility of providing services remotely, at a distance, through the use of information technology and communication, that is, through virtual means. The third article of Complementary Law 116 of 2003 provides that the service is deemed to be provided, and the tax due, at the place of establishment or, in the absence of the establishment, at the place where the provider is domiciled. And the article fourth establishes that the provider establishment is
\end{abstract}


the place where the taxpayer develops the activity of rendering services, permanently or temporarily, and that configures economic or professional unit. In this scenario, a conflict of municipal competence arises: which Municipality is competent to tax taking into account that the place of service provision is on cyberspace. The research concludes by that Municipality where the physical establishment of the site owner or e-mail is located, identified in the records kept by the Foundation for Research Support of the State of São Paulo.

Keywords/Palabras-claves/Mots-clés: Telework, Tax over Services, Municipal competence.

\section{Introdução: a prestação de serviços e a internet}

A globalização, as novas tecnologias, a moderna informática, inclusive a robotização, possibilitam a prestação de serviços por meio da internet, de forma remota, sem a necessidade de os contratantes estarem fisicamente em algum território. Essa realidade, muitas vezes, facilita a vida das pessoas no cotidiano, porém algumas questões jurídicas surgem no decorrer dessas práticas. Com o intuito de apresentar a modalidade de prestação de serviços via teletrabalho, o presente estudo pretende também debater a questão tributária, mais precisamente o imposto sobre serviços que incide sobre o trabalho realizado pelo seu prestador.

O assunto torna-se extremamente relevante por ser muito pouco difundido no Brasil, havendo somente poucas indagações. A doutrina e a jurisprudência caminham a passos lentos, o que torna mais ainda necessária a pesquisa do presente tema. Além disso, essa nova modalidade laboral propiciada pelas tecnologias da informação e da comunicação vem, cada vez mais, sendo utilizada pelo mundo contemporâneo, o que possibilita o surgimento de conflitos e questionamentos daí decorrentes, para os quais o Direito ainda não encontra respostas.

Pretende-se demonstrar o debate que existe acerca do tema por meio da interdisciplinaridade entre o direito do trabalho e questões correlatas como é a fiscal. Por meio da aplicação do método dialético, que consiste na contradição de ideias, em razão da divergência legal e jurisprudencial existente, objetiva-se encontrar uma solução para os conflitos que surgem a partir dessa relação jurídica.

Dessa forma, essa popularização da internet possibilita que o cliente contrate e contate o profissional, para a realização dos serviços, via essa plataforma. O profissional presta os 
serviços através do site ou do e-mail, sendo o próprio serviço realizado pelo prestador e encaminhado ao cliente por meios eletrônicos de transmissão de dados.

Com efeito, com a prestação de serviços via internet surge a eventual aplicabilidade da legislação tributária, no que concerne ao aspecto espacial, o que será objeto do presente estudo.

Inicialmente, analisar-se-á a atual legislação que regula a tributação das prestações de serviços no que tange ao campo espacial de incidência de tal tributação (Imposto sobre Serviços - ISS). Além disso, pretende-se analisar critérios a serem utilizados com a finalidade de definir o município competente para tributar os serviços realizados via internet.

\section{Teletrabalho: uma nova modalidade de prestação de serviços à distância}

O teletrabalho é modalidade de trabalho realizado à distância, a partir da qual alguém presta serviços por meio das ferramentas de comunicação e informação (notoriamente internet), distante geograficamente de seu tomador de serviços realizado em qualquer lugar.

O teletrabalho é modalidade de prestação de serviços propiciado, notadamente, com a propagação das tecnologias que permitiram a comunicação e o amplo acesso à informação. $\mathrm{O}$ fenômeno da globalização, juntamente com estes elementos fez com que o mundo seja ou possa ser plano. (FRIEDMAN, 2009, p. 27).

A origem do teletrabalho pode estar ligada ao ano de 1791, quando o engenheiro Claude Chappe, na França (que à época, estava vivendo um período de alto índice de desemprego, e os trabalhadores urbanos tinham uma jornada de 16 horas em média) juntou-se aos seus irmãos para dar novos rumos à sua vida e ao mundo do trabalho e construiu a primeira linha telegráfica entre Paris e Lille. (FINCATO; CRACCO NETO, 2013, p. 56-59).

Nesse cenário, cumpre destacar as ideias de Fincato e Cracco Neto:

Como o telégrafo foi desenvolvido por razões bélicas, no início, sua administração era feita pelo Ministério da Guerra. Em 1798, no entanto, ele passou a ser tutelado pelo Ministério do Interior. A partir de então podem ser distinguidos dois períodos da telegrafia aérea com desfecho em 1830. Antes do período da Monarquia Francesa e até seu fim, a administração era realizada por Pierre-François Marchal e, sobretudo, Alphonse Foy. Entretanto, em 1833, as Ordenações Reais de 24 de agosto criaram 38 artigos que definiam o estatuto de todos os (tele) trabalhadores das linhas telegráficas, muito embora este termo ainda não fosse utilizado na época - esses documentos são acessíveis, porém não são suficientemente legíveis. (2013, p. 63). 
A organização e o funcionamento do telégrafo ótico à época demonstra que já existia o teletrabalho. Com efeito, destaca-se a explicação de Fincato e Cracco Neto:

Um pessoal submetido a uma hierarquia rígida e bem definida fazia funcionar o telégrafo. Tratava-se de um regime praticamente militar. Ao topo, podia ser vista a administração central que considerada confusa pelos irmãos Chappe, começou a se (re) organizar a partir de 1823, sendo melhor definida dez anos mais tarde, passando a ser composta por três administradores, um chefe e dois adjuntos em quatro escritórios físicos e distantes das torres de telégrafo o que vem caracterizar o elemento topográfico, pré requisito para a constituição do teletrabalho [...]. (2013, p. 63).

O uso das tecnologias, propiciadas pelo fenômeno globalizatório, fez surgir vários tipos de relações, inclusive trabalhistas, com o surgimento de novas formas de prestação de serviços. É nesse cenário que surge o teletrabalho. $\mathrm{O}$ trabalho à distância desterritorializa o ambiente normal da prestação de serviços e mitiga a subordinação do trabalhador em relação ao empregador, criando novos paradigmas para a ciência jurídica.

O teletrabalho é modalidade de trabalho, a partir da qual alguém presta serviços por meio das ferramentas de comunicação e informação (notoriamente internet), distante geograficamente de seu tomador de serviços. A relação poderá ser autônoma ou subordinada, importando ao Direito do Trabalho a segunda hipótese, quando se apresentará como contrato empregatício (espécie do gênero laboral).

As novas tecnologias e a globalização foram as grandes responsáveis pela relação, cada vez mais estreita, entre os indivíduos, empresas e cidadãos de um modo geral, inclusive transpondo as barreiras de determinado país. Nas palavras de Thomas Friedman, houve um achatamento do mundo, na medida em que a presença física das pessoas bem como dos trabalhadores passa a ser insignificante. (2009, p. 27).

Segundo Vólia Bomfim Cassar,

[...] a globalização, a moderna informática e o progresso nas telecomunicações propiciaram o aumento de contratação de trabalhadores à distância. É possível e, algumas vezes até mais barato, a contratação de empregados que executem o serviço em sua própria casa, na rua ou praça, ou em outro estado ou país. (2010, p. 181).

O teletrabalho significa, de acordo com uma interpretação literal do termo, trabalho à distância, mas atualmente diz-se-o especificação deste. Ou seja, nem todo o trabalho à distância será teletrabalho. 
Para fins trabalhistas, nele o teletrabalhador presta serviços de maneira constante e subordinada a empregador com estrutura principal localizada em região remota do local da efetiva prestação do serviço, em caráter oneroso. (FINCATO, 2006, p. 48). Para a prestação dos serviços o trabalhador utiliza meios de telecomunicação para o recebimento, trato e transmissão de informação que, então, é erigida à principal matéria-prima do setor de serviços. (FINCATO, 2009).

Ortiz Chaparro assim conceitua teletrabalho: "es trabajo a distancia, utilizando las telecomunicaciones y por cuenta ajena". (Apud FINCATO, 2006, p. 47).

Existem cinco modalidades possíveis de teletrabalho quanto ao local de prestação de serviços. São elas: em domicílio, em centros satélites, em telecentros, em telecottages e, por fim, móvel ou nômade. (FINCATO, 2011, p. 365).

Ainda, quanto ao grau de conectividade, o teletrabalho poderá ser off-line, one way line ou on-line. (FINCATO, 2011, p. 365).

No Brasil não há regulação específica de teletrabalho. No entanto, destaca-se o projeto de lei 4505/2008 que, infelizmente, contém conceitos inadequados frente à doutrina internacional, conteúdo contraditório e, às vezes, vieses inconstitucionais.

Recentemente, no entanto, foi promulgada a Lei $12.551 / 2011$, que modificou o texto do artigo $6^{\circ}$ da CLT, equiparando o trabalho à distância ao trabalho presencial e permitindo ao empresário dirigir, supervisionar e controlar seus empregados mediante o uso de meios telemáticos. $\mathrm{O}$ artigo passou a ter a seguinte redação:

Art. $6^{\circ}$ Não se distingue entre o trabalho realizado no estabelecimento do empregador, o executado no domicílio do empregado e o realizado a distância, desde que estejam caracterizados os pressupostos da relação de emprego.

Parágrafo único. Os meios telemáticos e informatizados de comando, controle e supervisão se equiparam, para fins de subordinação jurídica, aos meios pessoais e diretos de comando, controle e supervisão do trabalho alheio. (BRASIL, Lei n. 5.452, 1943).

A Lei 13.467, de março de 2017, que dispõe sobre a reforma trabalhista, prevê nos arts. 75-A ao 75-E, algumas regras acerca do funcionamento do Teletrabalho. 
$\mathrm{Na}$ Organização Internacional do Trabalho, o teletrabalho é normatizado pela Convenção n. $177^{1}$ de 1996 , sobre trabalho em domicílio e pela Recomendação n. $184^{2}$, não ratificadas pelo Brasil.

Sem dúvida, o teletrabalho veio para ficar. Assim como a globalização e as tecnologias de informação e comunicação que tornam o mundo plano, como já dito. No entanto, é tarefa de operadores e pesquisadores jurídicos apontar os prováveis efeitos funestos que podem vir em anexo às maravilhas do trabalho a distância. Se não houver (de parte dos interessados e dos que têm o dever legal e institucional de tutelá-los) a devida atenção e pontual atuação, prejuízos graves ocorrerão e, seguramente, não se limitarão ao patrimônio jurídico de um trabalhador individualmente considerado, sequer à estrutura socioeconômica de seu país de origem. Atingirão ao conjunto de direitos sociais galgados pela humanidade nos últimos séculos que serão deixados às gerações futuras irremediavelmente aniquilados. (FINCATO, 2011, p. 371).

\section{Lugar da prestação de serviços}

A Constituição Federal, no art. 156, inciso $\mathrm{III}^{3}$, prevê a competência delegada dos Municípios para a instituição do $\operatorname{ISS}^{4}$. Com exceção dos serviços de transporte intermunicipal e interestadual e de comunicação, todos os demais serviços, desde que definidos em lei complementar, estariam sujeitos à incidência do ISS, instituído pelos Municípios.

A partir do dispositivo constitucional, Emerson Drigo da Silva discorre que

\footnotetext{
${ }^{1}$ Trabalho a domicílio significa trabalho realizado por uma pessoa, na sua residência ou em outro local que não seja o local de trabalho do empregador, remunerado, resultando num produto ou serviço especificado pelo empregador, independentemente de quem provê o equipamento, materiais ou outros insumos, a não ser que esta pessoa tenha o grau de autonomia e independência econômica para ser considerado trabalhador independente segundo as leis nacionais.

${ }^{2}$ A expressão trabalho em domicílio significa o trabalho realizado no próprio domicílio do trabalhador, ou em outro local, em troca de remuneração, com o fim de elaborar produto ou serviço conforme especificações do empregador, independentemente de quem proporcione os equipamentos e materiais utilizados para a prestação (art. $1^{\circ}$ ); Deve haver igualdade de tratamento com os outros empregados com respeito à remuneração, aos direitos previdenciários, idade mínima de admissão e proteção à maternidade (art. $4^{\circ}$ ); quando for permitida a terceirização do trabalho em domicílio as responsabilidades dos tomadores de serviços e intermediadores serão fixadas conforme a legislação e jurisprudência nacionais do país (art. $8^{\circ}$ ), da Organização Internacional do Trabalho. (TYBUSCH, 2017, p. 71).

${ }^{3}$ Art. 156. Compete aos Municípios instituir impostos sobre:

III - serviços de qualquer natureza, não compreendidos no art. 155, II, definidos em lei complementar. (BRASIL, Constituição Federal, 1988).

${ }^{4}$ De acordo com o art. $1^{\circ}$, caput, da LC 116/2003, o fato gerador do ISS é a prestação dos serviços constantes da lista anexa, ainda que esses não se constituam atividade preponderante do prestador.
} 
Como se percebe, a $\mathrm{CF} / 88$ preferiu não definir, dentre os municípios que poderiam considerar-se competentes para a exigência do ISS sobre determinada prestação de serviço, qual seria o titular da competência para efetivamente exigir tal tributo - o do local em que ocorresse a efetiva prestação do serviço, aquele em que estivesse estabelecido o prestador do serviço ou aquele em que estivesse estabelecido o tomador do serviço -, deixando esta definição para lei complementar que, nos termos do art. 146, inciso I, da CF/88, viesse a dispor sobre conflitos de competência na instituição do referido tributo. (2001, p. 176-177).

Nesse contexto, quanto à colocação do problema acerca da definição exata de competência municipal no que concerne ao Município competente para exigir o ISS, faz-se necessário verificar o conteúdo da lei complementar.

Hugo de Brito Machado assevera que

a Lei Complementar n. 116, de 31 de julho de 2003, manteve a regra do art. 12, do Decreto-lei n. 406/68, segundo a qual o serviço considera-se prestado e o imposto devido no local do estabelecimento prestador, ou na falta do estabelecimento, no local do domicílio do prestador. Entretanto, foi pródiga no estabelecimento de exceções a essa regra. Assim é que estabeleceu nada menos do que 22 hipóteses nas quais o município competente para a cobrança do imposto não é necessariamente aquele no qual está localizado o estabelecimento prestador ou o seu domicílio. Como o Chefe do Poder Executivo vetou dois dos incisos do artigo que enumera tais exceções, ficaram estas reduzidas para vinte. A regra, portanto, segue sendo a de que o município competente para a cobrança do imposto de serviços de qualquer natureza é aquele no qual está situado o estabelecimento do prestador do serviço, ou não tendo este estabelecimento, o seu domicílio. Entretanto, restaram estabelecidas vinte exceções, nas quais o município competente para a cobrança do imposto é identificado por outro critério. (2017).

Heleno Taveira Torres explica:

[...] a competência tributária exige discriminação dos serviços diferenciados entre si, sempre por lei complementar (norma heterônoma da União), para garantir a certeza e previsibilidade das incidências (i); e que sejam essas hipóteses separadas entre as municipalidades segundo critérios de determinação do local da prestação do serviço (ii.1) ou do estabelecimento do prestador do serviço (ii.2), de modo a evitar eventuais conflitos territoriais e conferir segurança jurídica aos jurisdicionados. (2017).

Ainda, o autor Heleno Torres, discorrendo acerca da prestação de serviços, ensina que o sentido a ser atribuído ao termo constitucional prestação de serviços para o exercício de competência dos Municípios deverá ser aquele da legislação de direito privado, isto é, aquele construído nos artigos 593 e seguintes do Código Civil. (2017).

Continua o autor: 
No Direito Privado, o contrato de prestação de serviço caracteriza-se pela presença dos seguintes elementos: o prestador (ou devedor) que é contratado para prestar serviços (i), o tomador (ou credor) em favor de quem o serviço é prestado (ii); o objeto, que é a prestação de serviços, trabalho ou atividade lícita, material ou imaterial (iii) e; o pagamento de contraprestação (iv). Note-se que não estão abrangidos na disciplina do Código Civil contratos sujeitos às leis trabalhistas ou a normas especiais. (TORRES, 2017).

O artigo 114 do CTN prescreve que somente configura-se o fato gerador da obrigação tributária quando concretizado no mundo social aquele evento que reúna as condições necessárias e suficientes descritas na hipótese de incidência tributária. Ainda, deverá haver uma uniformidade de entendimento para solução dos casos de conflito de competência, a partir do artigo 114 do CTN e do disposto nos artigos $3^{\circ}$ e $4^{\circ}$ da Lei Complementar 116/2003. (TORRES, 2017).

Com efeito, propõe Torres que

\begin{abstract}
somente quando houver "prestação de serviços", o que somente poderá ser assim identificada mediante a presença da respectiva "causa" ou finalidade prática e jurídica do contrato de serviço, é que poderá ser exercida a competência municipal, na exigibilidade do ISS. Aqui fica afirmada tese fundamental: não existe vis attractiva absoluta do conceito de "estabelecimento", pela simples localização deste em dado município no qual seja praticado algum ato negocial. A incidência do ISS só se opera se presentes os requisitos do artigo 114 do CTN, ou seja, as condições necessárias e suficientes à ocorrência da efetiva prestação do serviço nos seus domínios. (2017).
\end{abstract}

Com efeito, tem que haver uma causa ou uma finalidade prática do contrato de serviço, pois os casos em que a prestação de serviço ocorreu em outros locais não podem ser imputados ao estabelecimento no qual somente operou-se uma "venda de contrato" (como nos planos de saúde), onde se deu apenas um "serviço-meio" (logística) ou onde se deu simples "coleta" (recebimento de material). (TORRES, 2017).

Segundo Heleno Torres:

Para melhor compreensão, importa lembrar que o caput do artigo 3o estabelece três regras para identificação do município competente: o local do estabelecimento prestador (i); o local do domicílio do prestador (ii); ou o local da prestação de serviços, para os serviços expressamente arrolados nos incisos I a XXII (ii). (2017). 
Afirma o autor que

\begin{abstract}
a regra geral é que o ISS seja cobrado no município onde se encontra o "estabelecimento prestador", seja ele sede ou filial, temporário ou permanente, formalmente constituído ou não. Contudo, não basta a forma. O importante é que o "estabelecimento prestador" configure uma "unidade econômica ou profissional", na qual seja concluído o serviço tributável pelo município. Assim, quando presente uma dada prestação de serviço, por unidade econômica ou profissional que caracterize o estabelecimento prestador, ainda que essa unidade seja temporária e não esteja constituída formalmente, teremos um "estabelecimento prestador" com força de atração para autorizar a competência tributária municipal, pela interpretação conjunta dos artigos 114 do CTN e artigos $3^{\circ}$ e $4^{\circ}$ da LC 116/2003. (TORRES, 2017).
\end{abstract}

O ISS deverá ser aplicado sempre que o serviço tributado (do fato jurídico tributário) realizar-se efetivamente, a partir das condições necessárias e suficientes à sua ocorrência (artigo 114 do CTN), apuradas pela causa jurídica dos serviços, e for provada a presença de um “estabelecimento prestador" (critério legal de conexão com a competência municipal), mesmo que não esteja formalmente constituído, bastando que se configure como unidade econômica ou profissional na qual o prestador executa os serviços, em caráter permanente ou temporário. (TORRES, 2017).

Com efeito, não basta a existência do estabelecimento; é necessário a prova da existência de estabelecimento e da efetiva prestação do serviço no seu território para atrair a competência do Município.

Os seguintes elementos assumem posição de destaque para caracterização da presença do estabelecimento:

manutenção de pessoal, material, máquinas, instrumentos e equipamentos necessários à execução dos serviços; existência de estrutura gerencial, organizacional e administrava compatível com as atividades desenvolvidas; inscrição na prefeitura do município e órgãos previdenciários; informação desse local como domicilio fiscal, para fins de pagamento de outros tributos; divulgação desse endereço em impressos, formulários, correspondência, contas etc. (TORRES, 2017).

Torres afirma que "a existência de filiais e contratos como eleição de foro em outros municípios, por si só, não são elementos suficientes a ensejar a mudança da competência ativa do ISS". (TORRES, 2017). 
Conclui Heleno Torres:

Logo, a partir da determinação das condições necessárias e suficientes para o fato jurídico tributário do ISS, o contribuinte será a unidade profissional onde sejam prestados os serviços (i) e o sujeito ativo será o município onde se verifique sua ocorrência (ii), segundo a localização do estabelecimento prestador, e não o lugar de residência do "tomador" dos serviços, ou no qual contratos isolados sejam firmados. Deveras, o fato jurídico tributário somente se aperfeiçoa, como alude o artigo 116, inciso I, do CTN, quando se verifica, na situação de fato, as circunstâncias materiais necessárias a que produza os efeitos que normalmente lhe são próprios. (2017).

Por tudo isso, para a determinação objetiva de obrigações tributárias, o ISS somente poderá ser exigido quando o estabelecimento prestador estiver localizado no território do município no qual sejam atendidos os requisitos de substância do artigo 114 do CTN e do artigo $4^{\mathrm{o}}$, da LC 116/2003, como direito fundamental de certeza jurídica. (TORRES, 2017).

A Lei Complementar n. 116, de 2003, estabelece no art. $3^{\circ}$, como regra geral, o critério espacial da hipótese de incidência do ISS nos seguintes termos:

Art. 3o $\mathrm{O}$ serviço considera-se prestado, e o imposto, devido, no local do estabelecimento prestador ou, na falta do estabelecimento, no local do domicílio do prestador, exceto nas hipóteses previstas nos incisos I a XXV, quando o imposto será devido no local: (BRASIL, Lei Complementar n. 116, 2003).

A novidade entre a Lei Complementar n. 116 e o diploma legal que a antecedeu (Decreto-Lei 406/1968) é o art. $4^{\circ}$ da LC, que expressamente determinou o próprio conceito de estabelecimento:

Art. $4^{\circ}$ Considera-se estabelecimento prestador o local onde o contribuinte desenvolva a atividade de prestar serviços, de modo permanente ou temporário, e que configure unidade econômica ou profissional, sendo irrelevantes para caracterizá-lo as denominações de sede, filial, agência, posto de atendimento, sucursal, escritório de representação ou contato ou quaisquer outras que venham a ser utilizadas. (BRASIL, Lei Complementar n. 116, 2003).

Nesse contexto, segundo Edison Aurélio Corazza: 
Quer na vigência do art. 12 do Decreto-Lei 406/68, quer nos termos da Lei Complementar n. 116/03, estabelecimento prestador não pode ser nada diferente do que o local, imputado pela lei, onde o homem, mediante o uso de utensílios de qualquer natureza, realiza uma atividade com fins econômicos. Esse critério, apesar das dificuldades de se determinar o local exato da ocorrência da realização de um serviço [...] não se afasta daquele implícito no Texto Constitucional. Ao contrário, é a sua própria manifestação. (2004, p. 37).

As exceções estão previstas nos incisos I a XXV do art. $3^{\circ}$, onde o imposto será devido em locais expressamente determinados, mas sempre em conexão com o local da realização do serviço.

Veja-se a seguinte ementa da $2^{\text {a }}$ Turma do Superior Tribunal de Justiça que interpreta o estabelecimento prestador previsto na Lei Complementar 116/2003:

TRIBUTÁRIO. AGRAVO INTERNO NO AGRAVO EM RECURSO ESPECIAL. ISS. SUJEIÇÃO ATIVA. ARRENDAMENTO MERCANTIL. ENTENDIMENTO FIRMADO EM RECURSO REPETITIVO. RESP 1.060.210/SC. ESTABELECIMENTO PRESTADOR. NÚCLEO DO SERVIÇO. UNIDADE COM PODER DECISÓRIO SOBRE A OPERAÇÃO. REEXAME DE PROVAS. NÃO CABIMENTO. SÚMULA 7/STJ. AGRAVO INTERNO IMPROVIDO.

I. Agravo interno interposto contra decisão publicada em 05/05/2017, que, por sua vez, julgara recurso interposto contra acórdão publicado na vigência do CPC/73. II. Na vigência do revogado art. 12, a, do Decreto-lei 406/68, a competência tributária para a cobrança do ISS era do Município em que localizada a sede do estabelecimento prestador do serviço, ou, na falta deste, do domicílio do contribuinte. Com a superveniência da Lei Complementar 116/2003, nos termos dos seus arts. $3^{\circ}$, caput, e $4^{\circ}$, o tributo passou a ser devido ao Município em que prestado o serviço, desde que ali haja um estabelecimento do contribuinte que configure uma unidade econômica ou profissional, sendo irrelevante a denominação de sede, filial, agência, posto de atendimento, sucursal, escritório ou contato. Esse é o entendimento consolidado, em sede de recurso especial representativo de controvérsia repetitiva, no tocante à incidência de ISS sobre o serviço de leasing mercantil, hipótese em que o tributo será devido ao Município em que localizada unidade da instituição financeira com poder decisório sobre a operação de arrendamento mercantil (STJ, REsp 1.060.210/SC, Rel. Ministro NAPOLEÃO NUNES MAIA FILHO, PRIMEIRA SEÇÃO, DJe de 05/03/2013). III. O Tribunal de origem, em ação anulatória, assentou que, no caso, não se poderia atribuir à sede da instituição financeira qualquer exercício de poder decisório quanto à celebração do contrato de leasing. A revisão desse entendimento demandaria reexame de provas, providência vedada, em sede de Recurso Especial, nos termos da Súmula 7/STJ. IV. Agravo interno improvido. (DISTRITO FEDERAL, Superior Tribunal de Justiça, 2017).

Para efeito de incidência do ISS, é relevante trazer o conceito de estabelecimento prestador previsto na Lei Complementar 116/2003. Para Sergio Pinto Martins: 
Para efeito de ISS, estabelecimento prestador será o local da atividade do contribuinte, onde há o fornecimento de trabalho ou a cessão de direitos. Há a possibilidade de existirem vários estabelecimentos prestadores, desde que a empresa os possua, como matriz e filiais. Os estabelecimentos auxiliares que não tiverem autonomia jurídica e econômica não poderão ser considerados como estabelecimentos prestadores para efeito do ISS. Dependendo, porém, do ramo empresarial adotado pela empresa, há diversos nomes para o estabelecimento, como escritório, consultório, armazém, fábrica, oficina, atelier, agência, depósito, etc. [...] É onde o contribuinte tem as máquinas, equipamentos para prestação de serviços, onde é administrada a empresa. (2017, p. 158-159).

Com efeito, percebe-se que o estabelecimento prestador tem que configurar unidade econômica de produção (empresa) ou profissional (profissionais liberais ou autônomos). Do contrário, não será considerado estabelecimento prestador. Se houver num local apenas mesa e telefone, sem que se constitua em unidade econômica ou profissional, não será estabelecimento prestador e, por consequência, não incidirá ISS $^{5}$.

Sergio Pinto Martins explica:

A regra do estabelecimento prestador prestigia a regra de o ISS ser devido onde o serviço for prestado, isto é, da territorialidade para a cobrança do tributo, desde que o estabelecimento prestador configure unidade econômica ou profissional. Exemplo é a existência no local de filial, agência, posto de atendimento, sucursal, escritório de representação ou contato que se caracterizem como unidade econômica ou profissional. O ISS será devido a este município. (2017, p. 159)

A norma contida no art. $3^{\circ}$ da LC 116/2003 constitui exceção ao princípio da territorialidade, e insta saber onde está o estabelecimento prestador dos serviços, na medida em que será aí que se paga ISS. Se a empresa tem sede em São Paulo e presta serviços em Bauru, onde não possui nenhum estabelecimento prestador, o ISS é devido em São Paulo, pois é nesta cidade que está o estabelecimento prestador. (MARTINS, 2017, p. 160).

Bernardo Ribeiro de Moraes ressalta que o ISS é "devido no município onde está localizado o estabelecimento prestador e não onde o serviço é executado". (1984, p. 490). Se a empresa tem sede no Rio de Janeiro e presta serviços em Marília, onde não possui nenhum

\footnotetext{
${ }^{5}$ Essa é a razão pela qual o legislador paulistano estabeleceu: Art. 174, $\S 1^{\circ}$. Decreto 56.235, de 3.7.2015, do Município de São Paulo - A existência de estabelecimento prestador que configure unidade econômica ou profissional é indicada pela conjugação, parcial ou total, dos seguintes elementos: I -manutenção de pessoal, material, máquinas, instrumentos e equipamentos próprios ou de terceiros necessários à execução dos serviços; II -estrutura organizacional ou administrativa; III -inscrição nos órgãos previdenciários; IV -indicação como domicílio fiscal para efeito de outros tributos; V -permanência ou ânimo de permanecer no local, para a exploração econômica de atividade de prestação de serviços, exteriorizada, inclusive, através da indicação do endereço em impressos, formulários, correspondências, "site" na internet, propaganda ou publicidade, contratos, contas de telefone, contas de fornecimento de energia elétrica, água ou gás, em nome do prestador, seu representante ou preposto.
} 
estabelecimento prestador, o ISS é devido no Rio de Janeiro, pois é nesta cidade que está o estabelecimento prestador. (MARTINS, 2017, p. 160).

Sobre a prestação de serviços e o critério para a incidência do ISS em caso de conflito, dispõe Hugo de Brito Machado:

[...] uma empresa de consultoria econômica, ou jurídica, é solicitada para analisar a situação de determinada empresa ou grupo empresarial, em Município diverso daquele em que é estabelecida. Ou até com estabelecimento em vários Municípios. Manda sua equipe até a sede da empresa cliente e ali é realizada a coleta dos dados necessários ao estudo. Essa coleta de dados é completada em outros Municípios. A análise destes dados e a emissão do parecer respectivo é feita, porém, na sede da empresa prestadora do serviço. (Apud CORAZZA, 2004, p. 26).

Em que lugar o trabalho adquire relevância jurídica a ponto de definir o local de sua realização? Diante dessa dificuldade natural da identificação do lugar da realização do serviço, deve a lei complementar, diploma legislativo constitucionalmente autorizado para dispor acerca de conflitos de competência ${ }^{6}$, estabelecer os critérios $^{7}$ necessários à fixação do local da ocorrência do fato imponível, sempre observando a limitação estabelecida pela Constituição ${ }^{8}$.

\section{Local do estabelecimento prestador, no caso de serviços prestados via internet}

A situação torna-se emblemática na medida em que, em se tratando de teletrabalho, não se sabe qual é efetivamente o local da prestação de serviços, tendo em vista que o trabalho é realizado no ciberespaço.

Com efeito, questiona-se qual é o local do estabelecimento prestador de serviços, quando a prestação ocorre através de meios virtuais. E qual é o local da prestação de serviços na internet.

Emerson Drigo da Silva explica que:

\footnotetext{
${ }^{6}$ Art. 146. Cabe à lei complementar:

I - dispor sobre conflitos de competência, em matéria tributária, entre a União, os Estados, o Distrito Federal e os Municípios; (BRASIL, Constituição Federal, 1988).

${ }^{7}$ Em geral, local da prestação de qualquer obrigação (inclusive relativa ao serviço) é o lugar de seu adimplemento. É o lugar em que se há de fazer a prestação. Entretanto, para efeitos jurídicos, esse local da prestação pode ser determinado através de inúmeros fatores como, por exemplo, a vontade dos contratantes, a natureza da obrigação, etc. Um critério deve ser adotado. (MORAES apud CORAZZA, 2004, p. 26).

${ }^{8}$ A Lei Complementar não poderia, por exemplo, dispor que o ISS será sempre devido ao Município da Capital do Estado, independente de onde for prestado. Tal dispositivo contraria o princípio constitucional da autonomia municipal, assim como a própria existência dos Municípios na Federação Brasileira. (MACHADO apud CORAZZA, 2004, p. 26).
} 
Para definir o local do estabelecimento que presta serviços via internet, o qual se utiliza, via de regra, de um site ou um $e$-mail seu para receber os pedidos de serviços e entregar tais serviços a seus clientes, entendemos necessária a adoção de um critério que possibilita a vinculação de meio virtual (o site ou $e$-mail) a um estabelecimento físico, com localização em ponto determinado de certo território. Caso contrário, tornar-se-ia impossível a aplicação da legislação que regula o ISS, tendo em vista a impossibilidade de determinar onde tal tributo poderia ser exigido. Lembramos, mais uma vez, que vários critérios poderiam ser adotados, limitando-se, no entanto, o presente estudo a propor um critério razoável, à luz da legislação nacional vigente, relativa ao ISS, e da (parca) regulamentação da internet em nosso país, que possibilite a determinação do local em que o ISS poderia ser exigido, nos casos em que for possível sua exigência. Assim, parece-nos razoável entender que o estabelecimento prestador, nos serviços prestados via internet, seria aquele estabelecimento físico ao qual estaria afeto o site ou $e$-mail utilizado na referida prestação de serviços. Desta forma, o estabelecimento prestador dos serviços poderia ser identificado através da verificação do titular do site ou e-mail (meio virtual utilizado), constante do registro destes junto ao órgão responsável pela efetivação de tais registros. (2001, p. 180).

Para análise do presente estudo, é importante verificar o Anexo II da Resolução n. 001/98 do Comitê Gestor Internet do Brasil. Depreende-se da referida resolução que um site ou um e-mail, registrados no Brasil sob determinado domínio, estariam sempre vinculados ao número de CNPJ do titular deste domínio. Assim, seria possível vincular o meio virtual (site ou e-mail) a um estabelecimento físico localizado em território brasileiro e, portanto, num determinado município, que seria competente para exigir o ISS, isto é, titular de seu domínio, com a finalidade de determinar o local em que se situa o estabelecimento prestador de serviços. (SILVA, 2001, p. 182).

O titular do domínio, ou seja, o que presta serviços via internet, será vinculado ao domínio do seu meio virtual (qual localidade está registrado) e, assim, definir a competência para a tributação do ISS.

Como visto alhures, considera-se local da prestação dos serviços, nos termos do art. $3^{\circ}$ da Lei Complementar n. 116/03, aquele em que se localiza o estabelecimento prestador do serviço.

Emerson Drigo da Silva conclui que

[...] chegaríamos à conclusão inequívoca de que, em conformidade com a legislação nacional que regula os conflitos de competência em matéria de ISS, o local da prestação de serviços seria aquele no qual se localizasse o estabelecimento físico sob cuja titularidade estivesse registrado o site ou e-mail utilizado na prestação de serviços. (2001, p. 183).

Em caso de serviços prestados em estabelecimentos físicos, a interpretação (STJ) é no sentido de que o local da prestação dos serviços seria aquele em que efetivamente se desenvolvessem as atividades profissionais destinadas à consecução dos serviços contratados. 
Assim, pode-se dizer que, de acordo com essa interpretação, e no caso dos serviços prestados via internet, o tomador dos serviços contrata a execução de tais serviços por meio do site ou do e-mail mantido pelo prestador. Muitas vezes, o serviço é realizado por terceiros contratados pelo prestador, e que podem estar localizados ou não em seu estabelecimento físico e encaminhar seus resultados também através de seu site ou e-mail. (SILVA, 2001, p. 183)

Diante desse contexto, analisa Emerson Drigo da Silva:

Poder-se-ia entender, portanto, que a prestação de serviços é realizada através de um meio virtual (site ou e-mail), cuja determinação da localização física é impossível, com o que deveríamos procurar vincular tal meio virtual (onde ocorre a prestação de serviços) a um determinado estabelecimento físico. (2001, p. 184).

Para isso ser possível, teria que adotar o critério proposto anteriormente, o que se poderia chegar à conclusão de que o local em que se realizou a prestação de serviços foi o local onde se encontra o estabelecimento físico da sociedade detentor do domínio da internet sobre o qual se encontra registrado seu site ou e-mail. (SILVA, 2001, p. 184).

Dessa forma, se adotado o critério de determinação do estabelecimento prestador de serviços proposto anteriormente, e mesmo que adotada a interpretação do STJ, sempre teríamos como local da prestação dos serviços contratados aquele correspondente a localização do estabelecimento físico sob cujo domínio se encontrar registrado o site veiculado na internet, seja este estabelecimento apenas uma sala, seja ele um armazém. (SILVA, 2001, p. 184-185).

Em razão dessa nova modalidade de prestação de serviços, o critério para a definição do município competente para a exigência do ISS incidente sobre a prestação de serviços via Internet é, segundo Emerson Drigo da Silva,

Estabelecimento prestador dos serviços será sempre aquele que detém o domínio, registrado junto à FAPESP ${ }^{9}$, sob o qual encontra-se cadastrado o site ou $e$-mail através do qual se dá a prestação dos serviços; e na medida em que a prestação de serviços ocorre através do (ou mesmo no próprio) site ou e-mail, o local da prestação dos serviços seria sempre aquele em que se encontre o estabelecimento físico do titular do domínio sob o qual encontra-se registrado o site ou e-mail. (2001, p. 185).

Com efeito, com a finalidade de aprofundamento do presente estudo, questiona-se: como seria exigido o ISS sobre a prestação de serviços via Internet realizada por meio virtual (site ou e-mail) registrado em país estrangeiro?

O autor Emerson Drigo da Silva responde a esse questionamento, ressaltando que se o titular do domínio através do qual se dá a prestação dos serviços estivesse estabelecido em

\footnotetext{
${ }^{9}$ No Brasil, responde por tais registros, a Fundação de Amparo à Pesquisa do Estado de São Paulo (FAPESP) Resolução do Comitê Gestor Internet do Brasil.
} 
território brasileiro (e sendo possível identificá-lo), poder-se-ia aplicar o critério proposto acima. Porém, a aplicação desse critério exigiria uma eficiente comunicação entre os municípios brasileiros (ou entre a FAPESP ou outro órgão criado para tanto, à qual recorreriam os municípios para identificar os prestadores de serviços) e o órgão, no país onde se encontra registrado o domínio através do qual ocorre a prestação de serviços, responsável pela outorga de tal registro. Isso porque, primeiramente, é necessário identificar o prestador de serviços, bem como o município em que se localiza, para, então, exigir o ISS devido.

No entanto, caso o titular do domínio através do qual se dá a prestação de serviços estivesse localizado fora do território nacional, não seria possível, através do critério proposto, tributar sua atividade pelo ISS. Segundo Emerson Drigo da Silva, isso ocorreria porque:

\begin{abstract}
Quanto ao motivo de ordem legal, temos que, em momento algum, a legislação brasileira (seja constitucional, seja infraconstitucional) autoriza os municípios a instituir e exigir o ISS sobre prestações de serviços realizadas ou iniciadas no exterior, como, aliás, ocorre com o ICMS (conforme o art. 155, II, in fine da CF/88, que autoriza tal exigência no caso do ICMS); Quanto ao motivo de ordem prática, não seria factível que qualquer município simplesmente pretendesse exigir o ISS em outro país, onde estivesse localizado estabelecimento e outros bens pertencentes ao prestador de serviços. (2001, p. 186).
\end{abstract}

Portanto, para evitar a tributação pelo ISS, basta que o prestador dos serviços via Internet estivesse localizado fora do território brasileiro e mantivesse os meios virtuais de prestação dos serviços registrados, também, em outro país. Isso imporia aos municípios brasileiros grandes perdas com relação ao ISS sobre os serviços prestados via Internet. Assim, diante da legislação atualmente existente, o critério anteriormente proposto limita-se a tributação apenas a prestadores de serviços estabelecidos em território nacional e que, em princípio, mantenham meios virtuais registrados junto à FAPESP, para a definição do município competente para exigir o ISS, nos serviços prestados via Internet ${ }^{10}$. (SILVA, 2001, p. 186-187).

Como conclusão, propõe Emerson Drigo da Silva:

10 Com efeito, não incide ISS sobre serviços provenientes do exterior, revelando-se, até mesmo, uma inconstitucionalidade. Isso porque: a) tal serviço é prestado exclusivamente nos limites territoriais de país estrangeiro, nos termos da legislação pertinente; b) os Municípios brasileiros não têm competência para instituir ISS sobre serviço executado fora de seus limites territoriais, segundo entendimento do STJ; c) a fruição de serviço prestado do exterior por tomador situado no país não consiste em fato gerador do ISS, pois a CF/1988 atribuiu aos Municípios competência para tributar o serviço prestado no seu território; c.ii) o $\S 3^{\circ}$ do art. 156 da CF/1988, com a atual redação dada pela EC 37/2002 revela que o fato gerador do ISS ocorre no município em que se dá a prestação do serviço, pois atribui à lei complementar competência para excluir da incidência do ISS a exportação de serviço para o exterior. Note-se que tal "exclusão" somente se justifica caso admita-se que, nos termos da CF/1988, o ISS incide apenas no local da prestação do serviço (no caso, em Município brasileiro) e não onde esteja situado o tomador do serviço (no caso, em território estrangeiro), pois, se assim não o fosse, tal exclusão seria desnecessária em razão da inexistência de fato gerador em Município brasileiro. (BORGES, 2004, p. 138). 
Como visto, a adoção dos critérios propostos no presente estudo nos permitiria identificar, como município competente para exigir o ISS - tanto se considerado o local do estabelecimento prestador quanto se considerado o local da efetiva prestação -, aquele em que se localizasse o estabelecimento físico do titular do site ou e-mail, identificado nos registros mantidos pela FAPESP através de seu número de CNPJ; no entanto, o critério proposto no presente estudo apresenta uma limitação territorial que poderia acabar por impedir a exigência do ISS por municípios brasileiros, na medida em que tal critério somente se mostraria útil se aplicado a prestadores de serviços que possuam estabelecimento físico em território brasileiro e que, além disso, mantenham o meio virtual através do qual se dá a prestação de serviços registrado junto à FAPESP. (2001, p. 188).

Pode-se entender o site como um meio físico, intangível, lógico, virtual e de mídia, que pode desenvolver uma série de atividades, as quais podem ser as seguintes:

\begin{abstract}
- divulgação de banners: ou seja, a disponibilização de um espaço para divulgação de determinada publicidade. Ressaltando, ainda, que o site poderá, além de realizar o serviço de divulgação, conectar o usuário ao site do banner divulgado; - salas de chat: atividade onde os sites disponibilizam espaços virtuais para que várias pessoas troquem informações reciprocamente; - criação de site: serviço no qual empresa provedora, ou não, desenvolve o design de criação do site, ou seja a disponibilização dos banners, os serviços, os links, enfim toda a diagramação do site; - webmail: permite ao usuário a visualização do seu e-mail em qualquer parte do mundo, desde que o computador esteja conectado à rede; - phonemail: disponibiliza ao usuário o acesso ao seu e-mail por telefone, escutando as informações contidas em seu endereço; - faxmail: permite ao usuário a recepção de uma cópia do e-mail via fax, através de um número previamente determinado; - videoconferência: permite ao usuário comunicar-se com outras pessoas determinadas, utilizando recursos de áudio e vídeo, permitindo que o conferencista e participantes visualizem-se. (MELO, 2007, p. 264)
\end{abstract}

Ainda, o site pode ser entendido como um instrumento de difusão de informações, de serviços e bens, bem como recebimento de solicitações pelos clientes. Além disso, pode ser feita a aceitação do pedido através do site, emissão de ordens de pagamento e concretização dos negócios. Essa diversidade não permite caracterizar o site como um autêntico estabelecimento, na medida em que, para fins tributários (lançamento de impostos, emissão de notas fiscais, escrituração de livros, etc), poderia ser considerado um mero escritório administrativo, distinto do local da efetiva prestação de serviços. (MELO, 2007, p. 264-265).

A utilização de instrumentos eletrônicos para a prestação de serviços torna difícil a caracterização do local da sua efetiva realização, como é o caso das pessoas participantes estarem situadas em distintos lugares (estabelecimento prestador, provedor que hospeda o site $e^{11}$ e usuário/cliente). (MELO, 2007, p. 265).

[...] na Internet, muitas vezes não é possível reconhecer facilmente de onde o interlocutor está interagindo. Muitos sites têm determinação “.com”, sem o sufixo de país (por exemplo, sem o “.br” em seguida) o que teoricamente significa que estão localizados nos Estados Unidos. Só que vários deles apenas estão registrados nos Estados 
Nesse sentido, aponta-se a solução trazida por Emerson Drigo da Silva:

Ponderável o critério sugerido no sentido de determinar a vinculação entre o meio virtual (site ou e-mail) utilizado na prestação dos serviços e o estabelecimento físico do prestador dos serviços (num determinado Município) através do número de inscrição no Cadastro Nacional das Pessoas Jurídicas do Ministério da Fazenda (CNPJ/MF) e órgão responsável pela efetivação do registro como detentor do domínio do meio virtual Fundação de Amparo à Pesquisa do Estado de São Paulo (Fapesp). (Apud MELO, 2007, p. 265).

A prestação de serviços, no teletrabalho, é no ambiente virtual. O ciberespaço é um ambiente que permite inúmeras possibilidades de mundo "real". Pode-se afirmar que se trata de um local real, porém não físico. É um ambiente onde pessoas do mundo todo podem interagir sem estar, de fato, presentes. É um novo espaço de comunicação, representação e interação. O termo ciberespaço, em sua etimologia, já propõe essa nova noção: cyber-espaço, ou seja, um espaço diferente, cibernético, com novas possibilidades e implicações. (MONTEIRO, 2011).

Nesse diapasão, o ciberespaço possibilita a transmissão de dados e informações de um lugar para qualquer outro de forma célere e eficaz, além de possibilitar a interação entre pessoas de um modo não físico, porém trata-se de possibilidades reais que acontecem no mundo físico, mas de uma forma cibernética.

O ciberespaço deve ser concebido como um mundo virtual global coerente, independente de como se acede a ele e como se navega nele. Tal qual uma língua, cuja consistência interna não depende de que os seus falantes estejam, de fato, pronunciando-a, pois eles podem estar todos dormindo, em um dado momento imaginário, o ciberespaço, como uma virtualidade disponível, independe das configurações específicas que um usuário particular consegue extrair dele. (SANTAELLA, 2004, p. 40-41).

No seu sentido mais amplo o ciberespaço refere-se a um sistema de comunicação eletrônica global que reúne os humanos e os computadores em uma relação simbiótica que cresce exponencialmente graças à comunicação interativa. Trata-se, portanto, de um espaço informacional, no qual os dados são configurados de tal modo que o usuário pode acessar, movimentar e trocar informação com um incontável número de outros usuários. (SANTAELLA, 2004, p. 45).

Por fim, segundo leciona Lucia Santaella:

Unidos e não tem nenhuma existência física nesse país. Uma tendência mundial é assumir definitivamente o endereço eletrônico como localização da origem ou efeito do ato. Assim, se uma empresa brasileira registra um site como ".com”, em vez de ".com.br", pode ter de se sujeitar às leis de diversos países no caso de questões jurídicas internacionais. (PINHEIRO, 2009. p. 39). 
O ciberespaço será considerado como todo e qualquer espaço informacional multidimensional que, dependente da interação do usuário, permite a este o acesso, a manipulação, a transformação e o intercâmbio de seus fluxos codificados de informação. Assim sendo, o ciberespaço é o espaço que se abre quando o usuário conecta-se com a rede. Por isso mesmo, esse espaço também inclui os usuários dos aparelhos sem fio, na medida em que esses aparelhos permitem a conexão e troca de informações. Conclusão, ciberespaço é um espaço feito de circuitos informacionais navegáveis. Um mundo virtual da comunicação informática, um universo etério que se expande indefinidamente mais além da tela, por menor que esta seja, podendo caber até mesmo na palma de nossa mão. (2004, p. 45).

Percebe-se, desse modo, que o ciberespaço se trata de um mundo virtual que é muito pequeno, porém capaz de envolver todas as informações existentes no planeta interagidas pelo usuário. É possível, por meio do ciberespaço, denominado espaço informacional, comunicar e trocar informações com um número indeterminado de humanos usuários de e para qualquer lugar do mundo.

Ressalta-se o entendimento do STJ nos casos de processamento de material biológico e da análise clínica, no qual a $1^{\text {a }}$ Turma criou novo critério de competência territorial, qual seja: local da contratação ou do pagamento, diverso do estabelecido pela Lei Complementar 116/03, que elegeu como critério o local do estabelecimento prestador, e absolutamente incongruente com o eleito pela $1^{\text {a }}$ Seção no julgamento do REsp 1.060.210/SC. (DISTRITO FEDERAL, Superior Tribunal de Justiça, 2015).

Portanto, na relação de teletrabalho, pode-se entender que o local da prestação de serviços é o local onde as informações são recebidas, vinculando o meio virtual ao meio físico, no qual está registrado o site ou e-mail.

\section{Conclusão}

Portanto, é claro a existência de mais de um elemento de conexão apto para atribuir a competência a uma certa municipalidade para a cobrança do ISS no teletrabalho. Pode-se vislumbrar o estabelecimento prestador dos serviços e o local onde se encontra o usuário e/ou cliente. Alguns falam, inclusive, no local onde se encontra o provedor que hospeda o site ou email.

Pode-se entender como competente, para a cobrança do ISS, aquele Município (estabelecimento prestador), em que se localiza o estabelecimento físico do titular do site ou email, identificado nos registros mantidos pela FAPESP através de seu número de CNPJ; No Brasil, a Resolução do Comitê Gestor Internet do Brasil atribuiu à Fundação de Amparo à 
Pesquisa do Estado de São Paulo (FAPESP) a responsabilidade por tais registros, como visto anteriormente.

Deve-se fazer uma vinculação entre o meio virtual (site ou e-mail) utilizado na prestação dos serviços e o estabelecimento físico do prestador dos serviços (num determinado Município) através do número de inscrição no CNPJ e órgão responsável pela efetivação do registro como detentor do domínio do meio virtual (Fundação de Amparo à Pesquisa do Estado de São Paulo - Fapesp).

Por derradeiro, ressalta-se que neste ensaio tentou-se verificar qual é o Município competente para cobrar o ISS nos serviços prestados em regime de teletrabalho e verificou-se que essa temática necessita de aprofundamento e de críticas. No entanto, entende-se por uma ideia de que o caminho ora percorrido reúne as condições necessárias de modo a demonstrar que o elemento de conexão previsto na Lei Complementar 116 de 2003 (estabelecimento prestador) juntamente com a interpretação da vinculação do meio virtual ao meio físico, é possível ter um critério apto a solucionar o conflito existente entre as municipalidades para a cobrança do ISS quanto aos serviços prestados pelo meio virtual, notoriamente, mediante o regime de teletrabalho.

\section{Referências bibliográficas}

BORGES, Eduardo de Carvalho. O ISS, os serviços provenientes do exterior, e a jurisprudência. In: MACHADO, Rodrigo Brunelli (Coord.). ISS na Lei Complementar n. 116/2003. São Paulo: Quartier Latin, 2004, p. 138.

\section{CASSAR, Vólia Bomfim. Princípios Trabalhistas, Novas Profissões, Globalização da}

Economia e Flexibilização das Normas Trabalhistas. Niterói: Impetus, 2010, p. 181.

CORAZZA, Edison Aurélio. Imposto sobre a prestação de serviços - local da prestação e a determinação da competência tributária. In: MACHADO, Rodrigo Brunelli (Coord.). ISS na

Lei Complementar n. 116/2003. São Paulo: Quartier Latin, 2004, p. 15-38.

DISTRITO FEDERAL. Superior Tribunal de Justiça. Resp n. 1060210/SC, da $1^{\text {a }}$ Turma. Relator: Ministro Napoleão Nunes Maia Filho. Brasília, 26 de agosto de 2015. Disponível em: $<$ https://ww2.stj.jus.br/processo/pesquisa/?tipoPesquisa=tipoPesquisaNumeroRegistro\&termo 
$=200801101098 \&$ totalRegistrosPorPagina $=40 \&$ aplicacao=processos.ea $>$ Acesso em: out. 2017.

DISTRITO FEDERAL. Superior Tribunal de Justiça. AgInt n. AREsp 1074607/SP, da $2^{\mathrm{a}}$ Turma. Relatora: Ministra Assusete Magalhães. Brasília, 03 de outubro de 2017. Disponível em:

$<$ https://ww2.stj.jus.br/processo/pesquisa/?tipoPesquisa=tipoPesquisaNumeroRegistro\&termo $=201700658655 \&$ totalRegistrosPorPagina $=40 \&$ aplicacao=processos.ea $>$ Acesso em: out. 2017.

FINCATO, Denise Pires; CRACCO NETO, Heitor Barbieri. Teletrabalho: De Chappe a Nilles. Revista Justiça do Trabalho, Porto Alegre: HS Editora, ano 30, n. 358, out. 2013, p. 56-59.

. Teletrabalho Transnacional, Dumping Social e a Rerum Novarum: Reflexões. In: ALMEIDA, Ronald Silka de; SANTOS, Willians Franklin Lira dos (Org.). Rerum Novarum: estudos em homenagem aos 120 anos da encíclica papal. Curitiba: Juruá, 2011, p. 365.

. Teletrabalho: Aproximações Epistemológicas. Porto Alegre: Editora Magister, 2009. Disponível em: $<$ http://www.editoramagister.com/doutrina_ler.php?id=578> Acesso em: 27 set. 2011.

. Teletrabalho: uma análise juslaboral. In: STÜRMER, Gilberto; STÜRMER, Amélia Elisabeth Baldoino da Silva (Org.). Questões Controvertidas de Direito do Trabalho E Outros Estudos. Porto Alegre: Livraria do Advogado, 2006, p. 47.

FRIEDMAN, Thomas L. O mundo é plano - o mundo globalizado no século XXI. Rio de Janeiro: Objetiva, 2009, p. 27.

MACHADO, Hugo de Brito. Conflito de competência quanto ao ISS no leasing financeiro. Interesse Público - IP, Belo Horizonte, ano 15, n. 82, nov./dez. 2013. Disponível em:<http://www.bidforum.com.br/bid/PDI0006.aspx?pdiCntd=99061>. Acesso em: 4 out. 2017. 
MARTINS, Sergio Pinto. Manual do ISS. São Paulo: Saraiva, 2017, p. 158-159.

MELO, José Eduardo Soares de. ISS: teoria e prática. São Paulo: Malheiros, 2007, p. 264.

MONTEIRO, Silvana Drumond. O Ciberespaço: o termo, a definição e o conceito. In:

Revista de Ciência da Informação. Londrina: Revista de Ciência da Informação, v. 8, n. 3, jun. 2007. Disponível em: < http://dgz.org.br/jun07/Art_03.htm> Acesso em: 02 nov. 2011.

MORAES, Bernardo Ribeiro de. Doutrina e prática do ISS. São Paulo: Revista dos Tribunais, 1984, p. 490.

PINHEIRO, Patrícia Peck. Direito Digital. São Paulo: Saraiva, 2009. p. 39.

SANTAELLA, Lucia. Navegar no ciberespaço: o perfil cognitivo do leitor imersivo. São Paulo: Palus, 2004, p. 40-41.

SILVA, Emerson Drigo da. Aspecto espacial da incidência do ISS sobre os serviços prestados via internet. In: SCHOUERI, Luís Eduardo (Org.). Internet: o direito na era virtual. Rio de Janeiro: Forense, 2001, p. 175-190.

TAPSCOTT, Don; TAPSCOTT, Alex. Blockchain revolution: como a tecnologia por trás do Bitcoin está mudando o dinheiro, os negócios e o mundo. São Paulo: Senai, 2016, p. 33.

TORRES, Heleno Taveira. Tributação do ISS no eterno dilema sobre local da prestação do serviço. Disponível em: <https://www.conjur.com.br/2017-mai-24/tributacao-iss-eternodilema-local-servico> Acesso em: 10 out. 2017.

TYBUSCH, Jerônimo Siqueira; NUNES, Denise Silva. O Teletrabalho sob o enfoque da sustentabilidade multidimensional. In: COLNAGO, Lorena de Mello Rezende; CHAVES JUNIOR, José Eduardo de Resende; ESTRADA, Manuel Martín Pino (Coord.) Teletrabalho. São Paulo: LTr, 2017, p. 71. 


\title{
A TARIFAÇÃO DO DANO EXTRAPATRIMONIAL NO ÂMBITO DO DIREITO DO TRABALHO COMO FORMA DE INTER VENÇÃO DO ESTADO NA RELAÇÃO ENTRE PARTICULARES: ANÁLISE DE SUA CONSTITUCIONALIDADE
}

\author{
Mateus Eduardo Siqueira Nunes Bertoncini \\ Centro Universitário Curitiba - UNICURITIBA \\ Leonardo Sanches Ferreira \\ Centro Universitário Curitiba - UNICURITIBA
}

\begin{abstract}
Resumo
O presente trabalho visa analisar de que maneira a tarifação do dano extrapatrimonial no âmbito do direito do trabalho configura uma intervenção do Estado em relações privadas, bem como realizar estudo quanto à sua constitucionalidade. Partindo do estudo sobre a ordem econômica constitucional, a pesquisa analisa as inovações trazidas à Consolidação das Leis do Trabalho, que promovem a capitulação específica do dano extrapatrimonial na esfera trabalhista. Pela verificação de constitucionalidade, a atuação do Estado na tarifação do dano extrapatrimonial é elencado como forma determinante de intervenção indireta estatal na economia. Adotou-se a metodologia de pesquisa bibliográfica.
\end{abstract}

Palavras-chave: tarifação, dano extrapatrimonial, intervenção, constitucionalidade, direito do trabalho.

\section{Abstract/Resumen/Résumé}

The present study aims to analyze how the the rating of extrapatrimonial damage in the framework of labor law configures State intervention in private relations, as well as conduct study regarding its constitutionality. Starting from the study on the constitutional economic order, the research analyzes the innovations brought to the Consolidation of Labor Laws, which promote the specific capitulation of the extra-patrimonial damage in the labor sphere. By the verification of constitutionality, the State's action in the assessment of extra-financial damages is listed as a determinant of indirect state intervention in the economy. The methodology adopted was bibliographic research. 
Keywords/Palabras-claves/Mots-clés: rating, extra-patrimonial damage, intervention, constitutionality, labor law.

\section{Introdução}

Inerente ao constante processo de mudança e inovação social, econômica, tecnológica e cultural, faz-se necessária a revisão dos textos legislativos e dos regulamentos existentes no ordenamento jurídico. Indubitável que a sociedade caminha a passos largos e que as configurações sociais existentes no momento da criação de normas jurídicas da segunda metade do século XX não são as que hoje se vivenciam, sendo imprescindível sua atualização, com vistas ao alcance da realidade que deve ser albergada pelo direito.

No entanto, tal atividade de atualização e novação legislativa deve se dar de maneira responsável, pautada na conjugação entre os interesses de todos aqueles que são afetados direta ou indiretamente pela norma, ou seja, a função típica exercida pelo poder legislativo de legislar deve estar fundamentada nos anseios de toda a sociedade, não apenas nas vontades de parcela desta, salvo quando se trata da salvaguarda dos direitos de minorias, conforme principiologia constitucional. $\mathrm{O}$ mesmo vale para os poderes executivo e judiciário quando exercem função atípica criadora de normas.

A Constituição Federal da República Federativa do Brasil de 1988 eleva os princípios da livre iniciativa e do valor social do trabalho a fundamentos da ordem econômica, o que promove a reflexão acerca do conteúdo jurídico e social de ambos os conceitos na busca pela promoção da justiça social.

Neste cenário de modernização do ordenamento jurídico experimentado pela sociedade brasileira, emerge a Reforma Trabalhista, realizada em grande escala pela Lei $\mathrm{n}^{\mathbf{0}}$. 13.467, de 13 de julho de 2017, que altera substancialmente institutos de direito material e de direito processual no âmbito do direito do trabalho. Tal medida legislativa representa, em sua exposição de motivos, os anseios de uma sociedade globalizada e informatizada, que visa a superação dos dogmas do protecionismo trabalhista, fortemente criticado pelos idealizadores da Lei mencionada. Posteriormente ao início da vigência da Lei 13.467/17, a Presidência da República editou a Medida Provisória n ${ }^{\circ} .808$, de 14 de novembro de 2017, alterando cerca de 20 artigos constantes daquela.

Trata-se de significativa alteração do ordenamento jurídico, especificamente no que tange ao direito do trabalho e à Justiça do Trabalho, sendo necessário que a doutrina, a jurisprudência e a academia jurídica voltem sua atenção e seus estudos às mudanças sociais e 
econômicas decorrentes da Reforma, tendo como fio condutor os princípios constitucionais e obreiros na análise de sua aplicação.

A partir desta realidade, o presente artigo dedica-se ao estudo da tarifação do dano extrapatrimonial no âmbito do direito do trabalho, prevista no Título II-A, especificamente no artigo 223-G, a fim de verificar se tal dispositivo conforma-se aos ditames constitucionais. $\mathrm{O}$ posicionamento adotado pelo Supremo Tribunal Federal em casos anteriores de tarifação do dano moral é apresentado, para que se possa analisar uma eventual mudança de fundamentação e dispositivo quando do julgamento do presente dispositivo em controle concentrado de constitucionalidade.

Por fim, verifica-se se a Reforma Trabalhista, ao promover a tarifação do dano extrapatrimonial interfere de maneira significativa nas relações entre particulares e, consequentemente, na economia social. Tal enfoque se demonstra pertinente visto o contingente de demandas trabalhistas que objetivam o pleito de reparação extrapatrimonial.

Cumpre destacar que com o fim da vigência da Medida Provisória $n^{\circ} 808$, de 14 de novembro de 2017, e sua não conversão em lei, volta-se a aplicar a redação original da Lei n $^{\circ}$ 13.467/2017, implicando, consequentemente, também em problemas de direito intertemporal.

O presente estudo não objetiva tratar do assunto de maneira estanque, mas apresentar, a partir da busca bibliográfica e jurisprudencial, a construção de um raciocínio jurídico, com vistas à efetivação constitucional e à justiça social. O trabalho divide-se em três tópicos em que serão analisados, respectivamente, a ordem econômica constitucional, a tarifação do dano extrapatrimonial e a intervenção estatal na economia pela atividade legislativa.

\section{A ordem econômica constitucional brasileira}

A Constituição Federal da República Federativa do Brasil de 1988 estabelece que "a ordem econômica, fundada na valorização do trabalho humano e na livre iniciativa, tem por fim assegurar a todos existência digna, conforme os ditames da justiça social" (art. 170, CF/88). Para tanto, elenca como princípios norteadores da ordem econômica a soberania nacional, a propriedade privada, a função social da propriedade, a livre concorrência, a defesa do consumidor, a defesa do meio ambiente, a redução das desigualdades regionais e sociais, a busca do pleno emprego e o tratamento favorecido para as empresas de pequeno porte constituídas sob as leis brasileiras e que tenham sua sede e administração no País (art. 170, I a IX, CF/88). (BRASIL, 1988) 
Em que pese amplamente conhecida a dicção do referido artigo e de seus incisos, revela-se necessário o contínuo debate acerca do conteúdo normativo de cada uma dessas expressões para a compreensão sobre qual o papel do Estado perante a economia, ante a adoção de medidas interventivas ou abstensivas.

Vital Moreira leciona que a expressão ordem econômica pode apresentar três distintos sentidos. O primeiro sentido apresentado pelo referido autor corresponde "ao modo de ser empírico de uma determinada economia concreta", ou seja, "o que o caracteriza é a circunstância de referir-se não a um conjunto de regras ou normas reguladoras de relações sociais, mas sim a uma relação entre fenômenos econômicos e materiais. O segundo sentido apontado designa o conjunto de todas as normas que respeitam à regulação do comportamento dos sujeitos econômicos, qualquer que seja a natureza. "É o sistema normativo da ação econômica". Por fim, o terceiro sentido diz respeito à ordem jurídica da economia, este que serve de aparato para a construção do debate jurídico acerca da função e da posição da ordem econômica constitucional na realidade brasileira. (MOREIRA, 1973, p. 67-71)

Assim, ordem econômica passa ser compreendida como uma parcela da ordem jurídica, que compreende uma ordem pública, uma ordem privada, uma ordem econômica e uma ordem social. (GRAU, 2015, p. 59) Logo, a ordem econômica constitucional brasileira pauta-se na conjugação entre dois princípios aparentemente antagônicos, ante a necessária atuação de Estado na promoção da valorização do trabalho e sua presumida abstenção para o exercício da livre iniciativa.

O legislador, ao reconhecer a relação intrínseca existente entre direito e economia na persecução dos objetivos sociais, elevou os princípios do valor social do trabalho a da livre iniciativa ao patamar de fundamentos da República (art. $1^{\circ}, \mathrm{IV}, \mathrm{CF} / 88$ ), o que demonstra que a ordem econômica funda-se na atuação espontânea do mercado e na valorização do trabalho (BARROSO, 2001, p. 205). Nas palavras J. J. Gomes Canotilho, estes configuram princípios políticos constitucionalmente conformadores. (2006, p. 201)

Neste sentido, garantias previstas aos trabalhadores como salário mínimo, piso salarial, duração do trabalho, repouso semanal remunerado, férias, licenças à gestante e à paternidade, aposentadoria, seguro contra acidentes de trabalho, são alguns dos elementos que caracterizam a valorização social do trabalho. (DANTAS, 2004, p. 68) Neste sentido, a valorização do trabalho humano é um dos fatores que contribuem para se alcançar o desenvolvimento nacional. (BERTONCINI; PORTELLA JUNIOR, 2013, p. 194)

Em complemento à valorização do trabalho, a livre iniciativa tem seu ponto sensível na chamada liberdade de empresa, que pode ser entendida sobre três vertentes: "liberdade de 
investimento ou acesso; liberdade de organização; liberdade de contratação". (VAZ apud ARAUJO; SERRANO JUNIOR, 2006, p. 465) A livre iniciativa pressupõe a existência de algumas condições para seu exercício, "tais como o pluralismo, a democracia e a propriedade privada, assentadas na concepção liberal da economia." (TOLEDO, 2004, p. 176)

Fernando Herren Aguillar leciona que o Estado poderá desempenhar atividades econômicas em sentido estrito em duas hipóteses: "quando houver autorização constitucional e quando assim o permitir a lei fundada em motivo de segurança nacional ou relevante interesse público. E o Estado pode desempenhar serviços públicos, desde que previstos constitucionalmente.” (2006, p. 303)

Compete ao Estado, diante de tal problemática, delimitar seus espaços de atuação para que o fim de promoção de justiça social seja alcançado. Cabe, desta forma, compreender as formas de atuação estatal na economia, direta e indiretamente, esta que geralmente se operacionaliza pela forma de normatização ou fomento, e aquela que se dá pela atividade econômica em sentido estrito e pelo serviço público.

\subsection{Intervenção direta do estado na economia}

O texto constitucional estabeleceu, dentre as atribuições do Estado, a atuação direta na economia em casos específicos. Trata-se da tomada de postura pelo ente estatal que age como se privado fosse, ou seja, atua no mercado em concorrência e em iguais condições com os entes privados, comprometendo-se com a atividade produtiva.

O marco regulatória da intervenção direta do Estado na economia está previsto no artigo 173 da Constituição Federal, que assevera que "ressalvados os casos previstos nesta Constituição, a exploração direta de atividade econômica pelo Estado só será permitida quando necessária aos imperativos da segurança nacional ou a relevante interesse coletivo, conforme definidos em lei”. (BRASIL, 1988)

Eros Graus leciona que o termo segurança nacional é, no contexto da Constituição de 1988, relacionado à defesa nacional, que, não obstante, não há de conduzir sempre à exploração direta, pelo Estado, da atividade econômica, sendo que esta ocorrerá quando voltada a atender imperativos de segurança nacional. (2015, p. 279) Já no que tange ao relevante interesse coletivo, o autor assevera que está será verificado a partir da ponderação entre os princípios da dignidade da pessoa humana, dos valores sociais do trabalho e da livre iniciativa, da construção de uma sociedade livre justa e solidária, dentre outros. (2015, p. 191) 
Os casos ressalvados em lei, conforme doutrina de Eros Roberto Grau, referem-se aos artigos $177^{1}$ e 21, inciso XXIII ${ }^{2}$, da Constituição Federal. (2015, p. 276). Os referidos artigos versam sobre o monopólio atribuído à União na exploração de petróleo, gás natural e minério e minerais nucleares.

A intervenção direta é realizada quando o Estado cria as chamadas empresas estatais, na forma de empresas públicas e sociedades de economia mista, para atuarem no domínio econômico, como agentes, concorrendo com os particulares ou detendo o monopólio. Ocorre também a intervenção direta quando o Estado cria as agências reguladoras para regularem e fiscalizarem serviços e atividades econômicas. (CLARK, 2001, p. 33)

Cabe ressaltar que a intervenção do Estado na economia tem como fundamento o princípio da subsidiariedade, seguindo o raciocínio de que "primeiro deve ser identificada alguma necessidade por parte dos indivíduos em sociedade; depois se, por alguma razão, os próprios indivíduos não puderem suprir essa necessidade, deve o Estado intervir para o problema seja equacionado" (GRAÇA, 2016, p. 54). Juan Gonzales Moras assinala que "La idea de "subsidiariedad", tal como hemos visto, surge a los efectos de ordenar y separar las actividades públicas y las privadas. Ordenar los ámbitos de actuación del poder público y la sociedad civil. (2013, p. 81) Verifica-se, neste sentido, a valorização que o legislador atribui à livre iniciativa.

\subsection{Intervenção indireta do estado na economia}

A intervenção indireta do Estado no âmbito econômico possui arcabouço constitucional, especificamente em seu artigo 174, (BRASIL, 1988) ao determinar que como agente normativo e regulador da atividade econômica, o Estado exercerá, na forma da lei, as

\footnotetext{
${ }^{1} \mathrm{CF}$, Art. 177. Constituem monopólio da União:

I - a pesquisa e a lavra das jazidas de petróleo e gás natural e outros hidrocarbonetos fluidos;

II - a refinação do petróleo nacional ou estrangeiro;

III - a importação e exportação dos produtos e derivados básicos resultantes das atividades previstas nos incisos anteriores;

IV - o transporte marítimo do petróleo bruto de origem nacional ou de derivados básicos de petróleo produzidos no País, bem assim o transporte, por meio de conduto, de petróleo bruto, seus derivados e gás natural de qualquer origem;

V - a pesquisa, a lavra, o enriquecimento, o reprocessamento, a industrialização e o comércio de minérios e minerais nucleares e seus derivados, com exceção dos radioisótopos cuja produção, comercialização e utilização poderão ser autorizadas sob regime de permissão, conforme as alíneas b e c do inciso XXIII do caput do art. 21 desta Constituição Federal. (Redação dada pela Emenda Constitucional no 49, de 2006)

${ }^{2} \mathrm{CF}$, Art. 21. Compete à União:

XXIII - explorar os serviços e instalações nucleares de qualquer natureza e exercer monopólio estatal sobre a pesquisa, a lavra, o enriquecimento e reprocessamento, a industrialização e o comércio de minérios nucleares e seus derivados, atendidos os seguintes princípios e condições:
} 
funções de fiscalização, incentivo e planejamento, sendo este determinante para o setor público e indicativo para o setor privado.

A atuação estatal pauta-se em dois propósitos básicos, quais sejam preservar o mercado dos vícios do modelo econômico, como nos casos de concentração econômica, e assegurar a realização das finalidades maiores da ordem econômica constitucional de propiciar vida digna a todos e realizar a justiça social. (ARAÚJO; NUNES JUNIOR, 2006, p. 459)

Determina o parágrafo primeiro do artigo 174 que a "lei estabelecerá as diretrizes e bases do planejamento do desenvolvimento nacional equilibrado, o qual incorporará e compatibilizará os planos nacionais e regionais de desenvolvimento". Evidencia-se, desta forma, que a intervenção indireta do Estado na economia preconiza as diversidades existentes no país.

Celso Ribeiro Bastos e Ives Gandra Martins ensinam que "a intervenção indireta ocorre quando o Estado condiciona, motiva ou enquadra a atuação dos atores econômicos, nada obstante o fato de ele mesmo não assumir nenhum papel como produtor ou distribuidor de bens e serviços". (2004, p. 108)

Neste sentido, compete ao Estado, dentre outras funções, "preservar e estimular a livre iniciativa ao mesmo tempo em que procura assegurar a todos existência digna dentro dos ditames da justiça social e de parâmetros principiológicos contidos em todo o texto constitucional”. (VELOSO, 2008, p. 33)

É agente regulador. No que avulta a função de manter em nível adequado a atividade econômica, impedindo a sua aceleração excessiva, evitando a sua queda em profundidade - a recessão, pois a aceleração exagerada e a recessão são motivo de crises daninhas à sociedade, por exemplo, inflação e desemprego. Intercontectando a normatividade e a regulação, decorre o papel de fiscalizador da atividade econômica. (FERREIRA FILHO, 2011, p.92)

E neste ponto a pesquisa afunila a seu objeto específico de estudo, qual seja a tarifação do dano extrapatrimonial promovida pela Reforma Trabalhista, em que o Estado estabelece limites mínimos e máximos para a indenização do trabalhador e da empresa.

\section{Tarifação do dano extrapatrimonial na reforma trabalhista}

A Consolidação das Leis do Trabalho, popularmente reconhecida pela sigla CLT, foi decretada no dia $1^{\circ}$ de maio de 1943, (BRASIL, 1943) sob o regime ditatorial de Getúlio Vargas, com o objetivo de proteger o trabalhador urbano e rural, de forma individual e coletiva, 
regulamentar as normas incidentes sobre as relações de trabalho e criar um rito processual específico para a Justiça Obreira.

Nas palavras de Maurício Godinho Delgado, o direito do trabalho é o "complexo de princípios, regras e institutos jurídicos que regulam, no tocante às pessoas e matérias envolvidas, a relação empregatícia de trabalho, além de outras relações laborais normativamente especificadas" (2017, p. 47).

Tal compilado normativo alberga normas gerais do direito material do trabalho, cria institutos jurídicos específicos para determinadas categorias de trabalhadores, como professores e bancários, além de disciplinar as regras processuais a serem aplicadas no processo do trabalho, desde o processo de conhecimento até a fase de execução.

A reforma trabalhista, promovida pela Lei $n^{\circ}$. 13.467, de 13 de julho de 2017, (BRASIL (a), 2017), parcialmente modificada pela Medida Provisória $n^{\circ} .808$, de 14 de novembro de 2017, (BRASIL (b), 2017) alterou substancialmente a CLT e inovou em diversos institutos do direito do trabalho, dentre os quais destaca-se, para este trabalho, a regulamentação específica do dano extrapatrimonial, prevista n o Título II-A, entre os artigos 223-A a 223-G.

\subsection{Do dano extrapatrimonial trabalhista}

A discussão acerca das condenações experimentadas na Justiça do Trabalho que se pautam na tutela moral do trabalhador acompanha o crescimento do instituto do dano extrapatrimonial no direito brasileiro. É comum tanto ao magistrado, quanto ao advogado e ao estudioso do direito do trabalho a reflexão quanto aos parâmetros a serem adotados na quantificação do dano extrapatrimonial, permeando argumentos de previsibilidade, proporcionalidade e razoabilidade.

Clayton Reis, ao mencionar a relevância da proteção da esfera moral no direito do trabalho assinala:

O direito do trabalho é o ramo jurídico em cujo ambiente o estudo do dano moral deveria alcançar seu máximo desenvolvimento, em face da dimensão que assume na defesa dos valores contidos na pessoa do trabalhador - princípio Constitucional da dignidade da pessoa humana (artigo $1^{\circ}$, inciso III da CF/88). Nesse caso, se encontram em jogo a sua personalidade, os seus bens pessoais, a sua dignidade, privacidade e outros bens de valor que são relevantes. Esses valores pessoais se sobrelevam quando aludem ainda à dignidade do trabalho, princípio basilar dos direitos sociais prescritos no artigo $5^{\circ}$, inciso XIII e caput do artigo $6^{\circ}$ da Carta Magna. (2013, p. 78) 
A regulamentação do dano extrapatrimonial promovida pela Reforma Trabalhista e posteriormente alterada pela Medida Provisória $n^{\circ}$ 808, de 2017, merece especial atenção ante sua relevância jurídica, social e econômica. As condenações da justiça obreira decorrentes da violação do âmbito moral do trabalhador somam expressivos valores que afetam tanto as empresas como a sociedade em geral.

Diante desta problemática situação de fato e de direito, pela inexistência de critérios e parâmetros claros na lei e na jurisprudência, a Reforma Trabalhista capitulou a tutela dos bens extrapatrimoniais, inicialmente dispondo que à reparação de danos de natureza extrapatrimonial decorrentes da relação de trabalho aplicam-se apenas os dispositivos previstos no Título II-A da CLT, “do dano extrapatrimonial” (art. 223-A).

Desde a publicação do projeto que previu a criação deste artigo, muito se discutiu acerca da possível inconstitucionalidade de tal dispositivo pela expressa negativa de diálogo com as previsões legais constantes da Constituição Federal de 1988, do Código Civil de 2002 e demais legislações infraconstitucionais.

Insta ressaltar que a base jurídica para a construção da doutrina sobre a indenização referente ao dano extrapatrimonial encontra na Constituição Federal e no Código Civil suas bases, especificamente no artigo $5^{\circ 3}$, incisos $\mathrm{V}$ e X, do texto constitucional e nos artigos $186^{4}$, $927^{5}$ e $944^{6}$ do diploma civil, ao determinar a proteção da moral e que o dano causado será indenizável e que está será medida pela extensão do dano.

Em seguida, o art. 223-B conceitua o dano extrapatrimonial e determina que "causa dano de natureza extrapatrimonial a ação ou omissão que ofenda a esfera moral ou existencial da pessoa física ou jurídica, as quais são as titulares exclusivas do direito à reparação". Além

\footnotetext{
${ }^{3}$ Constituição Federal. Art. $5^{\circ}$ Todos são iguais perante a lei, sem distinção de qualquer natureza, garantindo-se aos brasileiros e aos estrangeiros residentes no País a inviolabilidade do direito à vida, à liberdade, à igualdade, à segurança e à propriedade, nos termos seguintes:

V - é assegurado o direito de resposta, proporcional ao agravo, além da indenização por dano material, moral ou à imagem;

$\mathrm{X}$ - são invioláveis a intimidade, a vida privada, a honra e a imagem das pessoas, assegurado o direito a indenização pelo dano material ou moral decorrente de sua violação;

${ }^{4}$ Código Civil. Art. 186. Aquele que, por ação ou omissão voluntária, negligência ou imprudência, violar direito e causar dano a outrem, ainda que exclusivamente moral, comete ato ilícito.

${ }^{5}$ Código Civil. Art. 927. Aquele que, por ato ilícito (arts. 186 e 187), causar dano a outrem, fica obrigado a reparálo.

Parágrafo único. Haverá obrigação de reparar o dano, independentemente de culpa, nos casos especificados em lei, ou quando a atividade normalmente desenvolvida pelo autor do dano implicar, por sua natureza, risco para os direitos de outrem.

${ }^{6}$ Art. 944. A indenização mede-se pela extensão do dano.

Parágrafo único. Se houver excessiva desproporção entre a gravidade da culpa e o dano, poderá o juiz reduzir, equitativamente, a indenização.
} 
da conceituação, o referido dispositivo legal promove a limitação da legitimidade para a reclamação ao direito de indenização.

Neste ponto específico, abre-se o debate quanto ao dano moral coletivo. O legislador deixou de tratar do referido ponto, o que gera incerteza jurídica, cabendo à doutrina e à jurisprudência determinarem de que maneira esta limitação será interpretada. $\mathrm{O}$ dano moral coletivo "decorre da ofensa do patrimônio imaterial de uma coletividade, ou seja, exsurge da ocorrência de um fato grave capaz de lesar o direito de personalidade de um grupo, classe ou comunidade de pessoas" (DALLEGRAVE NETO, 2010, p. 182), cabendo, em regra, ao Ministério Público do Trabalho atuar como representante processual da tutela do direito coletivo. Resta aberto o questionamento acerca da titularidade restrita prevista na reforma que pode, inclusive, resultar em cerceamento do direito coletivo.

Cabe a ressalva referente ao artigo 927 do Código Civil, que em seu parágrafo único determina que "haverá obrigação de reparar o dano, independentemente de culpa, nos casos especificados em lei, ou quando a atividade normalmente desenvolvida pelo autor do dano implicar, por sua natureza, risco para os direitos de outrem”, estabelecendo a responsabilidade objetiva, também aplicável ao direito do trabalho.

Na sequência, a Lei 13.467/17 estabeleceu em seu artigo 223-C que os bens juridicamente tutelados inerentes à pessoa natural são "a honra, a imagem, a intimidade, a liberdade de ação, a autoestima, a sexualidade, a saúde, o lazer e a integridade física são os bens juridicamente tutelados inerentes à pessoa física”. No entanto, a Medida Provisória nº 808/17 ampliou este rol e incluiu a etnia, a idade, a nacionalidade, e alterou o termo sexualidade para os termos gênero e orientação sexual como bens jurídicos albergados pela legislação obreira.

No que tange à proteção da pessoa jurídica, elencou-se como bens tutelados a imagem, a marca, o nome, o segredo empresarial e o sigilo da correspondência, conforme artigo 223-D, da CLT. Este dispositivo guarda relação direta com a Súmula no .227 do Superior Tribunal de Justiça, que assevera que a pessoa jurídica pode sofrer dano moral.

O artigo 223-E previu que a responsabilidade pelo dano extrapatrimonial é de todos os que tenham colaborado para a ofensa ao bem jurídico tutelado, na proporção da ação ou da omissão. Neste dispositivo vislumbra-se a presença dos princípios da razoabilidade e da proporcionalidade, admitindo-se o reconhecimento de culpa concorrente e até mesmo exclusiva da vítima. 
E seguindo o entendimento do Superior Tribunal de Justiça, previsto na Súmula $\mathrm{n}^{\mathrm{o}}$. $37^{7}$, o art. 223-F estabelece que a reparação por danos extrapatrimoniais pode ser pedida cumulativamente com a indenização por danos materiais decorrentes do mesmo ato lesivo. Em seus parágrafos estabelece que se "houver cumulação de pedidos, o juízo, ao proferir a decisão, discriminará os valores das indenizações a título de danos patrimoniais e das reparações por danos de natureza extrapatrimonial" e que a "composição das perdas e danos, assim compreendidos os lucros cessantes e os danos emergentes, não interfere na avaliação dos danos extrapatrimoniais".

Por fim, ao versar sobre o posicionamento a ser adotado pelo magistrado no momento da condenação, o artigo 223-G determina que ao apreciar o pedido, o juízo considerará a natureza do bem jurídico tutelado, a intensidade do sofrimento ou da humilhação, a possibilidade de superação física ou psicológica, os reflexos pessoais e sociais da ação ou da omissão, a extensão e a duração dos efeitos da ofensa, as condições em que ocorreu a ofensa ou o prejuízo moral, o grau de dolo ou culpa, a ocorrência de retratação espontânea, o esforço efetivo para minimizar a ofensa, o perdão, tácito ou expresso, a situação social e econômica das partes envolvidas e o grau de publicidade da ofensa (art. 223-G, CLT).

Em linhas gerais, apresenta-se, assim, as inovações trazidas pelo legislador ao tratar do dano extrapatrimonial no âmbito do direito. Cabe, desta forma, analisar especificamente a tarifação do dano prevista nos parágrafos $1^{\circ}$ a $5^{\circ}$ do artigo 223-G, da CLT, e verificar se estas disposições encontram-se em consonância com o entendimento emanado pelo Supremo Tribunal Federal quanto ao limite de atuação do Estado no âmbito econômico.

\subsection{Da tarifação do dano extrapatrimonial}

A Lei nº $13.467 / 17$, em seu artigo 223-G, parágrafo primeiro, incluiu à Consolidação das Leis do Trabalho a tarifação do dano extrapatrimonial e classificou a natureza da ofensa cometida em quatro níveis: ofensa de natureza leve, média, grave e gravíssima. Determinou, ainda, que em caso de julgamento procedente quanto ao pedido de dano extrapatrimonial, o magistrado deveria adotar parâmetros de forma não cumulativa a cada um dos níveis apresentados.

Com relação à ofensa de natureza leve, o inciso I determinou que o valor da indenização tem como limite máximo de condenação a soma equivalente três vezes o salário

\footnotetext{
7 “Súmula 37 - São cumuláveis as indenizações por dano material e dano moral oriundos do mesmo fato".
} 
contratual do ofendido. Já o inciso II estabeleceu que a ofensa de natureza média será indenizável com o teto de cinco vezes o último salário do ofendido. A natureza grave da ofensa enseja um valor de indenização que possui como limite máximo o valor equivalente à até vinte vezes o valor do salário contratual do ofendido. E, por fim, a ofensa de natureza gravíssima encontra limite em até cinquenta vezes o último salário contratual do ofendido.

Chama atenção a dicção adotada pelo legislador quando da escolha da expressão "salário contratual do ofendido", vez que é afeto ao direito obreiro a aplicação do princípio da primazia da realidade ${ }^{8}$. Faz-se tal sinalização por ser comum ao direito trabalhista o reconhecimento em juízo e a integração de parcelas recebidas pelo trabalhador a latere, ou extra folha, que alteram substancialmente a remuneração do trabalhador e consequentemente o valor a que teria direito de receber em caso de responsabilização da parte empregadora pelo dano extrapatrimonial.

Ocorre que a Medida Provisória $n^{\circ} .808$, de 14 de novembro de 2017, alterou o conteúdo do disposto no parágrafo primeiro do artigo 223-G da CLT, dando nova redação aos incisos que tarifam o dano extrapatrimonial. De acordo com a nova redação, a ofensa de natureza leve será indenizada em valor até três vezes o valor do limite máximo dos benefícios do Regime Geral de Previdência Social. A ofensa de natureza média em até cinco vezes o valor do limite máximo dos benefícios do Regime Geral de Previdência Social, seguida pela ofensa de natureza grave, indenizável em até vinte vezes o valor do limite máximo dos benefícios do Regime Geral de Previdência Social ou, por fim, para ofensa de natureza gravíssima, até cinquenta vezes o valor do limite máximo dos benefícios do Regime Geral de Previdência Social.

O parágrafo segundo, por sua vez, determina que se "o ofendido for pessoa jurídica, a indenização será fixada com observância dos mesmos parâmetros estabelecidos no $§ 1$ o deste artigo, mas em relação ao salário contratual do ofensor".

O parágrafo terceiro teve sua redação alterada pela Medida Provisória 808/17, sendo que o texto que determinava que na reincidência entre partes idênticas, o juiz poderá elevar o valor da indenização em dobro, foi substituído pela redação de que "na reincidência de quaisquer das partes, o juízo poderá elevar ao dobro o valor da indenização”.

\footnotetext{
8 "No Direito do Trabalho deve-se pesquisar, preferentemente, a prática concreta efetivada ao longo da prestação de serviços, independentemente da vontade eventualmente manifestada pelas partes na respectiva relação jurídica. A prática habitual - na qualidade de uso_altera o contrato pactuado, gerando direitos e obrigações novos às partes contraentes (respeitando a fronteira da inalterabilidade contratual lesiva)". DELGADO, Maurício Godinho. Curso de Direito do Trabalho. 3. ed. São Paulo: LTr, 2016, p. 211.
} 
A Medida Provisória 808/17 incluiu ainda os parágrafos quarto e quinto ao artigo 223G, prevendo que para fins de reincidência do dano extrapatrimonial, esta ocorrerá se a ofensa idêntica ocorrer no prazo máximo de dois anos, contado do trânsito em julgado da decisão condenatória e que os parâmetros estabelecidos no parágrafo primeiro, que versa sobre a tarifação, não são aplicáveis aos danos extrapatrimoniais decorrentes da morte.

Cumpre destacar que com o fim da vigência da Medida Provisória ${ }^{0}$ 808, de 14 de novembro de 2017, e sua não conversão em lei, volta-se a aplicar a redação original da Lei $\mathrm{n}^{\circ}$ 13.467/2017, implicando, consequentemente, também em problemas de direito intertemporal. Os apontamentos sobre tratamento desigual a trabalhadores que recebem salário desigual voltam à tona, evidenciando problemas ainda maiores para a doutrina e jurisprudência trabalhista.

\section{Da intervenção do Estado na economia pela atividade legislativa}

O estudo acerca do papel do Estado e sua atuação junto à economia permite concluir que a Reforma Trabalhista, consubstanciada pela Lei n ${ }^{\circ}$. 13.467/17 e pela Medida Provisória $\mathrm{n}^{\circ}$. 808/2017, configura intervenção do Estado na economia de forma indireta, ao passo que cria, extingue e altera institutos do direito material e processual do trabalho com evidente consequência economia mediata e imediata.

No que tange especificamente a tarifação do dano extrapatrimonial, torna-se discutível a constitucionalidade de tal medida tomando como parâmetro o posicionamento emanado pelo Supremo Tribunal Federal ao julgar tarifações anteriormente pretendidas, como será demonstrado na sequência do texto.

Ao destacar que o dano moral não deve sofrer tarifação legislativo, José Affonso Dallegrave Neto destacava que "a legislação positiva é omissa na tarifação dos danos morais e assim o faz de forma acertada, vez que, pela própria natureza dos direitos imateriais de personalidade, não é possível aplicar valores nominais e imutáveis a todas as situações concretas, indiscriminadamente." (2014. p. 185) O posicionamento adotado pelo autor deixa claro que a esfera moral não deve sofrer restrições ante seu caráter imaterial, não cabendo ao legislador determina, a priori, a quantificação devida no ato da condenação.

Nas palavras de Caio Mário da Silva Pereira: 
Na reparação por dano moral estão conjugados dois motivos, ou duas concausas: I) punição ao infrator pelo fato de haver ofendido um bem jurídico da vítima, posto que imaterial; II) pôr nas mãos do ofendido uma soma que não é o pretium doloris, porém o meio de lhe oferecer a oportunidade de conseguir uma satisfação de qualquer espécie, seja de ordem intelectual ou moral, seja mesmo de cunho material. (2001, p. 317)

Verifica-se, diante da inovação trazida pela Reforma Trabalhista uma intervenção do Estado na economia, quando impõe limites à indenização do dano extrapatrimonial no âmbito trabalhista. Faz-se, assim, necessário analisar o posicionamento adotado pelo Supremo Tribunal Federal, quando do julgamento da constitucionalidade de legislações infraconstitucionais que previam a tarifação do dano moral.

$\mathrm{O}$ artigo $5^{\circ}$, inciso $\mathrm{V}$, da Constituição Federal assegura "o direito de resposta, proporcional ao agravo, além da indenização por dano material, moral ou à imagem" e a partir de tal disposição é cediço o entendimento que o texto constitucional não recepcionou qualquer tentativa de tarifação do dano moral, valorizando o princípio da reparação integral.

O Código Brasileiro de Telecomunicações, Lei Federal $n^{\circ}$. 4.117, de 27 de agosto de 1962, (BRASIL, 1962) estipulava em seu artigo 84, parágrafos $1^{\circ}$ a $3^{\circ}$, a tarifação do dano moral, estabelecendo que "o montante da reparação terá o mínimo de 5 (cinco) e o máximo de 100 (cem) vezes o maior salário-mínimo vigente no País”. Tal dispositivo foi revogado pelo Decreto-lei $\mathrm{n}^{\circ}$ 236, de 28 de fevereiro de 1967.

Antes de sua revogação, o Código Eleitoral, Lei Federal nº 4.737 , de 15 de julho de 1965, (BRASIL, 1965) em seu artigo 243, parágrafo $2^{\circ}$, fez referência de aplicação ao disposto nos artigos 81 a 88 do Código Brasileiro de Telecomunicações, que, consequentemente, foi revogado pelo Decreto-lei n 236, de 28 de fevereiro de 1967.

Por fim, a Lei de Imprensa, Lei Federal nº. 5.250, de 9 de fevereiro de 1967, (BRASIL, 1967) dispôs em seu artigo 49 sobre a responsabilidade civil incidente sobre aquele que no exercício da liberdade de manifestação de pensamento e de informação, mediante dolo ou culpa, viole direito ou cause prejuízo a outrem. A tarifação criada pela Lei de Imprensa constou em seus artigos 51 e 52, sendo que o primeiro estipulou condenações, variando entre 2 (dois) a 20 (vinte) salários mínimos da região, e o segundo restringiu a condenação em dano moral da empresa que explora o meio de informação ou divulgação em até 10 (dez) vezes o valor máximo previsto no artigo 51.

O Superior Tribunal de Justiça emanou a súmula nº 281, em 28 de abril de 2004, com a dicção de que "a indenização por dano moral não está sujeita à tarifação prevista na Lei de 
Imprensa" (BRASIL, STJ, 2004), determinando que a tarifação fixada pela Lei de Imprensa não foi recepcionada pela Constituição Federal.

Posteriormente a matéria chegou ao Supremo Tribunal Federal e a Lei de Imprensa foi objeto de Arguição de Descumprimento de Preceito Fundamental (ADPF 130/DF), com julgamento em 30 de abril de 2009, e entendeu-se que a referida lei, em sua íntegra, não foi recepcionada pela Constituição Federal de 1988.

\begin{abstract}
A indenização por dano moral - depois de uma certa perplexidade inicial por parte dos magistrados - vem sendo normalmente fixada pelos juízes e tribunais, sem quaisquer exageros, aliás, com muita parcimônia, tendo em vista os princípios da equidade e da razoabilidade, além de outros critérios como o da gravidade e a extensão do dano; a reincidência do ofensor; a posição profissional e social do ofendido; e a condição financeira do ofendido e do ofensor. Tais decisões, de resto, podem ser sempre submetidas ao crivo do sistema recursal. Esta Suprema Corte, no tocante à indenização por dano moral, de longa data, cristalizou jurisprudência no sentido de que o art. 52 e 56 da Lei de Imprensa não foram recepcionados pela Constituição, com o que afastou a possibilidade do estabelecimento de qualquer tarifação, confirmando, nesse aspecto, a Súmula 281 do Superior Tribunal de Justiça. (BRASIL, STF, 2009).
\end{abstract}

O posicionamento adotado pelo Supremo Tribunal Federal foi de que os princípios da proporcionalidade e da razoabilidade devem ser utilizados como parâmetros para a condenação extrapatrimonial, sendo indevida qualquer tentativa de tarifação do dano moral. No julgamento, os ministros Cármen Lúcia, Cezar Peluso, Celso de Mello, Eros Grau, Menezes Direito e Ricardo Lewandowski, além do relator, ministro Carlos Ayres Britto, votaram pela total procedência da Arguição de Descumprimento de Preceito Fundamental (ADPF) 130. Pela procedência parcial pronunciaram os ministros Joaquim Barbosa, Ellen Gracie e Gilmar Mendes e o ministro Marco Aurélio, pela improcedência.

Vê-se, desta forma, que a tarifação do dano moral realizada pela Lei de Imprensa teve sua inconstitucionalidade declarada pelo Supremo Tribunal Federal, após decisão no mesmo sentido pelo Superior Tribunal de Justiça. Faz mister acompanhar a aplicação do texto apresentado pela Reforma Trabalhista, para se verificar a postura que será adotada pelos tribunais pátrios.

\title{
5. Conclusões
}

O Estado possui papel essencial na economia do país, seja pela atuação direta através de empresas públicas e sociedades de economia mista, seja pela sua atividade enquanto agente normativo e regulamentador da atividade econômica. A Constituição Federal de 1988 dedicou 
parte de seu texto à tutela da economia praticada no Estado brasileiro, primando pelos princípios da livre iniciativa e do valor social do trabalho.

Conforme analisado ao longo deste trabalho, a delimitação do campo de atuação no Estado em matéria econômica ainda constitui campo nebuloso para a doutrina e para jurisprudência, sendo comum ao estudioso do direito se deparar com questões que envolvam a discussão sobre a intervenção do Estado na economia.

Através da atividade legislativa, o Estado possui um aparato de condicionamento da realidade social, ou seja, por meio da normatividade criada pelo ente público se altera a realidade social tanto na atividade econômica propriamente dita, enquanto detentor do monopólio da concessão de alvarás para empresas por exemplo, como quando agente regulador que impõe limites a valores indenizatórios a serem pagos em caso de dano.

Este segundo caso é analisado na Reforma Trabalhista que prevê a tarifação do dano extrapatrimonial, condicionando sua indenização aos limites previstos em lei. A doutrina trabalhista critica fortemente os artigos referentes ao dano extrapatrimonial e pugnam pela declaração de sua inconstitucionalidade. Os juízes de primeiro grau e Tribunais Regionais do Trabalho ainda possuem um longo caminho até que o embate acerca da matéria seja pacificado e haja unidade no entendimento sobre o tema.

A pesquisa demonstrou, pela metodologia adotada de análise bibliográfica sobre as formas de intervenção do Estado na economia, do estudo pormenorizado do texto apresentado pela Reforma Trabalhista e pelos posicionamentos adotados pelos Tribunais Superiores, que para que a tarifação do dano extrapatrimonial trabalhista seja reconhecida como válida perante o ordenamento, faz-se necessária uma mudança de posicionamento do Supremo Tribunal Federal e do Superior Tribunal de Justiça.

A atualização e renovação das leis infraconstitucionais constitui atividade primordial ao Estado, enquanto mantenedor da ordem pública e da paz social. Ressalta-se, entretanto, que medidas de grande impacto social e econômico, como a Reforma Trabalhista, devem se fundamentar em profundo estudo social, econômico e cultural, para que não se incorram em injustiças graves e em desrespeito aos preceitos constitucionais, principalmente, na tutela da dignidade da pessoa humana.

\section{Referências bibliográficas}

AGUILLAR, Fernando Herren. Direito Econômico: Do Direito Nacional ao Direito

Supranacional. São Paulo: Atlas, 2006. 
ARAUJO, Luiz Alberto Araújo; NUNES JUNÍOR, Vidal Serrano. Curso de direito constitucional. 10. ed. rev. e atual. São Paulo: Saraiva, 2006.

BASTOS, Celso Ribeiro; MARTINS, Ives Gandra. Comentários à Constituição do Brasil: promulgada em 5 de outubro de 1988. São Paulo: Saraiva, 2004.

BERTONCINI, Mateus Eduardo Siqueira Nunes; PORTELLA JUNIOR, José Carlos. A responsabilidade social da empresa e a erradicação do trabalho escravo. In Revista Pensar, Fortaleza, v. 18, n. 1, p. 190-209, jan./abr. 2013.

BRASIL. Constituição da República Federativa do Brasil: texto constitucional promulgado em 5 de outubro 1988. Disponível em: <http://www.planalto.gov.br>. Acesso em 18/11/2017.

(a) Planalto. Medida Provisória ${ }^{\circ} 808$, de 14 de novembro de 2017. Altera a Consolidação das Leis do Trabalho. Disponível em: < http://www.planalto.gov.br/ ccivil_03/_ato2015-2018/2017/Mpv/mpv808.htm>. Acesso em 17/11/2017.

. Senado Federal. Lei no 5452, de 11 de janeiro de 1943. Institui a Consolidação das Leis do Trabalho. Disponível em: < http://www.planalto.gov.br>. Acesso em 18/11/2017.

Senado Federal. Lei Federal no .4 .117 , de 27 de agosto de 1962. Institui o Código Brasileiro de Telecomunicações. Disponível em: < http://www.planalto.gov.br/ ccivil_03/leis/L4117.htm>. Acesso em 22/11/2017.

. Senado Federal. Lei Federal no ${ }^{\circ}$ 4.737, de 15 de julho de 1965. Institui o Código Eleitoral. Disponível em: < http://www.planalto.gov.br/ccivil_03/leis/L4737.htm>. Acesso em 22/11/2017.

. Senado Federal. Lei Federal no ${ }^{\circ}$ 5.250, de 9 de fevereiro de 1967.Institui a Lei de Imprensa. Disponível em: < http://www.planalto.gov.br/ccivil_03/leis/L5250.htm>. Acesso em $22 / 11 / 2017$. 
(b) Senado Federal. Lei n ${ }^{0}$ 13.467, de 13 de julho de 2017. Altera a Consolidação das Leis do Trabalho. Disponível em: < http://legis.senado.leg.br/legislacao/DetalhaSigen.action?id=17728053>. Acesso em $17 / 11 / 2017$.

STJ (Superior Tribunal de Justiça) - Súmula no $\mathbf{2}$ 281. AGRAVO REGIMENTAL NO RECURSO ESPECIAL N. 323.856-RS (2001/0059908-1). Relatora: Ministra Nancy Andrighi. Disponível em: https://ww2.stj.jus.br/docs_internet/revista/eletronica/stj-revistasumulas-2011_21_capSumula281.pdf. Acesso em 22/11/2017.

STF (Supremo Tribunal Federal) - ADPF: 130 DF, Relator: Min. Carlos Britto, Data de Julgamento: 30/04/2009, Tribunal Pleno, Data de Publicação: DJe-208 Divulgação 05/09/2009, Publiação 06/11/2009. Vol. 02381-01 PP-00001. Disponível em: $<$ http://redir.stf.jus.br/paginadorpub/paginador.jsp?docTP=AC\&docID=605411> Acesso em 22/11/2017.

CANOTILHO, José Joaquim Gomes. Direito constitucional e teoria da constituição. 7. ed. Coimbra: Almedina, 2006.

CLARK, Giovani. O Município em face do Direito Econômico. Belo Horizonte: Del Rey, 2001.

DALLEGRAVE NETO, José Affonso. Responsabilidade civil no direito do trabalho. 5 . ed. São Paulo: LTr, 2014.

DELGADO, Maurício Godinho. Curso de direito do trabalho. São Paulo: LTr, 2016.

FERREIRA FILHO, Manoel Gonçalves. A constituição "econômica” de 1988. In: MARTINS FILHO, Ives Gandra da Silva; MEYES-PFLUG, Samantha Ribeiro (Org). A intervenção do estado no domínio econômico: condições e limites. São Paulo: Ltr: 2011.

GRAU, Eros Roberto. A ordem econômica na Constituição de 1988: interpretação e crítica. 8. ed. São Paulo: Malheiros, 2015. 
MORAS, Juan Gonzáles. Dimensión contemporaânea del principio de subsidiariedad estatal. In Revista Jurídica - UNICURITIBA. v. 2, n. 31, p. 56-86, 2013.

MOREIRA, Vital. A Ordem Jurídica do Capitalismo. Coimbra, Centelha, 1973.

PEREIRA, Caio Mário da Silva. Responsabilidade civil. 9a ed. Rio de Janeiro: Editora Forense, p. 317, 2001

REIS, Clayton. A Reparação do Dano Moral no Direito Trabalhista. Revista Eletrônica Tribunal Regional do Trabalho. V.2. Número 21. Agosto 2013.

TOLEDO, Gastão Alves de. O Direito Constitucional Econômico e sua eficácia. Rio de Janeiro: Renovar, 2004.

VELOSO, Yslyg Abreu. A intervenção indireta do Estado sobre o domínio econômico: o regime jurídico das agências reguladoras e sua contribuição para o projeto de desenvolvimento econômico-social brasileiro. (Dissertação de Mestrado em Direito) Universidade de Marília, São Paulo, 2008. 


\title{
MECANISMOS ESPECIAIS PARA A SEDIMENTAÇÃO DA TUTELA ANTIDISCRIMINATÓRIA DOS HOMOSSEXUAIS NAS RELAÇÕES TRABALHISTAS
}

\author{
Adriana de Abreu Mascarenhas \\ Universidade Federal da Paraíba - UFPB \\ Paulla Christianne da Costa Newton \\ Universidade Federal da Paraíba - UFPB \\ Universidade Estadual da Paraíba - UEPB \\ Centro Universitário de João Pessoa - UNIPÊ
}

\begin{abstract}
Resumo
As exclusões e limitações derivadas da orientação sexual arraigam-se na ampla disseminação de estigmas sociais e culturais, fundamentados em paradigmas historicamente cultuados e difundidos ao longo das épocas. Com efeito, nas relações laborais, a discriminação projeta-se na diferenciação de tratamento baseada na orientação sexual de um determinado trabalhador, em detrimento de seus atributos ou qualificações profissionais. As situações discriminatórias podem ocorrer na fase que antecede à contratação, no curso do pacto laboral, na dispensa e/ou até mesmo na fase posterior ao contrato. O presente ensaio tem como objetivo a análise dos instrumentos e medidas presentes no ordenamento jurídico brasileiro e em documentos internacionais que vedam às práticas e comportamentos prejudiciais aos trabalhadores em razão da sua orientação sexual.
\end{abstract}

Palavras-chave: orientação sexual, vínculo laboral, tutela antidiscriminatória.

\section{Abstract/Resumen/Résumé}

Las exclusiones y limitaciones derivadas de la orientación sexual están centradas en la diseminación de los estigmas sociales y culturales que se basan en los paradigmas tradicionales perpetuados al largo de las épocas en las distintas sociedades. En efecto, en las relaciones laborales, la discriminación proyectase en la diferenciación en el trato de un dicho trabajador basada en su orientación sexual. Las situaciones discriminatorias suelen pasar en las varias fases de la contratación laboral, en la fase anterior a la contratación, en el desarrollo del contrato de 
trabajo, en la ruptura del pacto laboral e incluso en la fase que sucede a la contratación laboral. El presente ensayo tiene como obyecto el análisis de los instrumentos y medidas presentados en el orden jurídico brasileño, así como en los documentos internacionales que prohíben las prácticas y comportamientos perjudiciales a los trabajadores en virtud de su orientación sexual.

Keywords/Palabras-claves/Mots-clés: orientación sexual, vínculo laboral, tutela antidiscriminatória.

\section{A título de introito}

As exclusões, limitações impostas e restrições imperantes, derivadas da orientação sexual arraigam-se na ampla disseminação de estigmas sociais e culturais, fundamentados em paradigmas historicamente cultuados e fartamente difundidos ao longo das épocas, em distintas sociedades e tradições.

Em concreto, "Foi no âmbito do cristianismo que a palavra sodomia passou a exprimir, entre outros atos, as relações homossexuais interditadas pelo judaísmo"; conduta estritamente criminalizada "passível de penas seculares extremamente rigorosas, como a castração ou a morte na fogueira, conforme o disposto em vários códigos europeus da Baixa Idade Média" (VAINFAS, 2007, p.117 e seguinte).

Neste panorama, sedimentado em pautas previamente concebidas e ideias tradicionalmente dominantes, concebidas sob a égide da heteronormatividade, assola uma gama diversificada de práticas discriminatórias que se difundem nos mais diversos cenários fáticos. Para PÉREZ CONTRERAS (2001, p.26),

La discriminación se puede entender como toda distinción, exclusión o restricción basada en la orientación sexual que tenga por objeto o por resultado menoscabar o anular el reconocimiento, goce o ejercicio, de cualquier homosexual, lesbiana o, inclusive, transexual, sobre la base de igualdad que reconocen los órdenes jurídicos nacional e internacional, de los derechos humanos, las libertades individuales y las garantías constitucionales en las esferas política, económica, social, laboral, cultural, civil o en cualquier otra esfera.

De fato, os preceitos excludentes, secularmente perpetuados, refletem-se em um conjunto negativo prejudicial ao coletivo homossexual, que pode resultar afetado em relação ao pleno usufruto dos direitos fundamentais, preceitos mínimos normatizados e das liberdades 
e garantias constitucionalmente estatuídas. Neste patamar, concebe-se que "tanto la igualdad como la desigualdad han sido básicas en la historia de las relaciones humanas, siendo la discriminación la definición social y política de la desigualdad” (MERINO, 2001).

Com efeito, o desenvolvimento integral do ser humano condiciona-se ao reconhecimento e pleno respeito aos direitos civis, políticos, sociais, culturais, econômicos e educacionais, conforme apregoa, tão oportunamente, a Convenção Americana de Direitos Humanos, de 1969.

O presente ensaio possui como objetivo analisar as medidas e instrumentos para a consecução da tutela antidiscriminatória na esfera das relações laborais, conformando-se como ambiente motor para o reconhecimento e a defesa dos fundamentais direitos humanos para além de qualquer rótulo sexual distintivo, como trataremos de analisar no presente ensaio.

Para tanto, a pesquisa utilizará os métodos de procedimento analítico-descritivo e o comparativo. $\mathrm{O}$ método analítico-descritivo será utilizado com vistas a fazer uma abordagem teórico-reflexiva sobre os critérios valorativos para a não discriminação nas relações laborais, bem como o exame das normas, mecanismos e instrumentos de tutela ao coletivo em análise. Em idêntico sentido, procurar-se-á realizar uma investigação sobre as decisões do Tribunal Superior do Trabalho brasileiro construídas sob o viés de proteção contra práticas discriminatórias no ambiente laboral.

\section{Critérios valorativos da não discriminação no âmbito das relações trabalhistas}

A Declaração da Organização Internacional do Trabalho relativa aos princípios e direitos fundamentais no trabalho ${ }^{1}$, em seu apartado segundo, reconhece, a eliminação da discriminação em matéria de emprego e ocupação entre os princípios relativos aos direitos fundamentais que todos os países membros têm o dever de respeitar, promover e realizar.

Tais documentos normativos são complementados pelos ditames da Convenção 111 da Organização Internacional do Trabalho ${ }^{2}$, que trata da discriminação em matéria de emprego e ocupação, ao enfatizar, em seu art. $1^{\circ}$, que o termo discriminação compreende,

1 Declaração da Organização Internacional do Trabalho relativa aos princípios e Direitos Fundamentais no trabalho, adotada na 86a sessão da Conferência Internacional do Trabalho, em junho de 1998.

2 Convenção no 111 da OIT, de 1958, sobre a discriminação em matéria de emprego e ocupação. 
a) toda distinção, exclusão ou preferência fundada na raça, cor, sexo, religião, opinião política, ascendência nacional ou origem social, que tenha por efeito destruir ou alterar a igualdade de oportunidade ou de tratamento em matéria de emprego ou profissão;

b) qualquer outra distinção, exclusão ou preferência que tenha por efeito destruir ou alterar a igualdade de oportunidades ou tratamento em matéria de emprego ou profissão que poderá ser especificada pelo Membro interessado depois de consultadas as organizações representativas de empregadores e trabalhadores, quando estas existam, e outros organismos adequados.

(...)

Por tanto, a discriminação nas relações laborais consiste na diferenciação de tratamento baseada em circunstâncias específicas de um determinado trabalhador, como a religião ou o sexo, em detrimento de seus atributos ou qualificações profissionais. Desta forma, impõe-se ao trabalhador ou trabalhadora uma desvantagem ou negam-se oportunidades naturalmente usufruídas por outros indivíduos.

Cabe ressaltar que a proibição de discriminar, no cerne da Convenção n ${ }^{0} 111$ da OIT, tanto abarca as pessoas que já participam de uma relação laboral, como também, àquelas que buscam à inserção no mercado de trabalho.

Além dos motivos referendados, explicitamente, como determinantes discriminatórios na Convenção $\mathrm{n}^{\mathrm{o}} 111$ da OIT, outros perfis particulares podem ser encontrados como motivadores de situações discriminatórias no cerne das relações laborais, como a deficiência e a orientação sexual.

Efetivamente, em nosso ordenamento jurídico vigente situam-se vários preceitos especificamente direcionados ao repúdio às condutas discriminatórias; com esta finalidade, a Carta Maior de 1988 consolida-se como máxima coluna. Com efeito, a nossa Carta Constitucional de 1988 firma a cidadania, a dignidade da pessoa humana e os valores sociais do trabalho e da livre inciativa como fundamentos da República Federativa do Brasil, em seu art. $1^{\circ}$, nos incisos II, III e IV, respectivamente; estabelece, igualmente, como objetivos fundamentais, entre outros, promover o bem de todos, sem preconceitos de origem, raça, sexo, cor, idade e quaisquer outras formas de discriminação (art. $\left.3^{\circ}, \mathrm{IV}\right)$.

Prossegue o texto Magno, em seu artigo $5^{\circ}$, assegurando que "Todos são iguais perante a lei, sem distinção de qualquer natureza, garantindo-se aos brasileiros e aos estrangeiros residentes no País a inviolabilidade do direito à vida, à liberdade, à igualdade, à segurança e à propriedade (...)". O inciso X, deste mesmo artigo, anuncia como invioláveis a intimidade, a 
vida privada, a honra e a imagem das pessoas, assegurado o direito a indenização pelo dano material ou moral decorrente de sua violação.

Por sua vez, muito apropriadamente, $\mathrm{o}$ art. $7^{\circ}$ da Lei Maior, fixa entre outros direitos dos trabalhadores urbanos e rurais a proibição de diferença de salários, de exercício de funções e de critério de admissão por motivo de sexo, idade, cor ou estado civil (inciso XXX). O posicionamento Constitucional prevalece como busca da eliminação da desigualdade em relação a determinados coletivos, passando por uma política antidiscriminatória.

Cabe reconhecer que ademais dos fatores previstos expressamente no cerne da Carta Constitucional de 1988, não se pode olvidar as chamadas causas inaceitáveis, ou seja, aquelas causas que não admitem o tratamento desfavorável em razão do próprio conjunto normativo dentro do ordenamento jurídico nacional (RODRIGUEZ-PIÑERO; FERNANDEZ LOPEZ, 1986).

Daí afirmar-se que "la conducta discriminatoria se cualifica por el resultado peyorativo para el sujeto que la sufre, que ve limitados sus derechos o sus legítimas expectativas", expressando-se mediante fatores que atentam contra a própria dignidade humana ${ }^{3}$.

Em similar enfoque, outro importante instrumento de rechaço às condutas discriminatórias em solo pátrio é a Lei 9029/95. Dito corpo normativo estabelece em seu art. $1^{\circ}$ :

\footnotetext{
É proibida a adoção de qualquer prática discriminatória e limitativa para efeito de acesso à relação de trabalho, ou de sua manutenção, por motivo de sexo, origem, raça, cor, estado civil, situação familiar, deficiência, reabilitação profissional, idade, entre outros, ressalvadas, nesse caso, as hipóteses de proteção à criança e ao adolescente previstas no inciso XXXIII do art. $7^{\circ}$ da Constituição Federal (BRASIL, Lei 9029/95).
}

Cabe interpretar-se o texto legal em conformidade com os preceitos constitucionais, em específico o art. $3^{\circ}$, IV, CF e os princípios da dignidade da pessoa humana e da igualdade. Desta maneira, torna-se evidente a necessidade de aplicar-se dita normativa aos casos de discriminação decorrentes da orientação sexual do trabalhador ou trabalhadora, antes, durante ou após o vínculo empregatício, em uma interpretação conforme os paradigmas constitucionais vigentes.

Consequentemente, permite-se a imposição do art. $4^{\circ}$ da lei supra para corrigir situações discriminatórias contra os trabalhadores, inclusive como decorrência de sua orientação sexual, nos seguintes moldes:

3 Ver Sentença do Supremo Tribunal Constitucional Espanhol 173/ 1994, de 7 de junio. 
O rompimento da relação de trabalho por ato discriminatório, nos moldes desta Lei, além do direito à reparação pelo dano moral, faculta ao empregado optar entre: (Redação dada pela Lei $\mathbf{n}^{\circ} \mathbf{1 2 . 2 8 8}$, de 2010)

I - a reintegração com ressarcimento integral de todo o período de afastamento, mediante pagamento das remunerações devidas, corrigidas monetariamente e acrescidas de juros legais; (Redação dada pela Lei $n^{0}$ 13.146, de 2015)

II - a percepção, em dobro, da remuneração do período de afastamento, corrigida monetariamente e acrescida dos juros legais.

Ex positis, imperam, em nosso sistema normativo, centelhas antidiscriminatórias, dispersas dentre institutos e princípios jurídicos, imprescindíveis à tutela das diferenças e à consecução dos princípios e liberdades constitucionais com sustentáculo na diversidade.

\section{Perspectivas da tutela antidiscriminatória no cerne das relações laborais}

A proibição de discriminação irradia seus efeitos em vários momentos na relação de trabalho, nas fases de inserção, desenvolvimento e término da relação laboral, assegurando a igualdade de oportunidades no mercado laboral e o tratamento não discriminatório nas condições de trabalho (PASTOR, 1993, p. 36 e segs.).

Deste modo, os artigos anteriormente citados da Carta Constitucional associados à lei 9029/95 estabelecem os parâmetros marcos que direcionam à tutela antidiscriminatória nas relações trabalhistas, proibindo-se qualquer tipo de comportamento injusto e diferenciador em razão da idade, raça, sexo, religião ou outra condição ou circunstância pessoal ou social valorada como fator tutelado, como a deficiência, orientação sexual ou represálias ante o exercício de reclamações judiciais ou administrativas contra o empresário (SAENZ DE MIERA; RANZ PERIAÑEZ, 1985).

É indubitável que existem vários mecanismos de discriminação que podem ser praticados nas relações laborais em razão da orientação sexual do trabalhador ou trabalhadora. As situações discriminatórias podem ocorrer na fase que antecede à contratação, no curso do pacto laboral, na dispensa e/ou até mesmo na fase posterior ao contrato.

Neste particular, desafortunadamente, os empregadores/contratantes tendem a relacionar capacidade, rendimento e aptidão profissional com orientação sexual. Importante acrescentar que, não raras vezes, terceiros, vinculados direta ou indiretamente ao pacto laboral, 
como clientes e fornecedores, também podem incorrer em atos de discriminação contra trabalhadores.

Ante tudo, assegura-se a igualdade de oportunidades no mercado laboral e o tratamento não discriminatório nas condições de trabalho e no exercício das atividades inerentes ao contrato laboral. Isto é, a tutela antidiscriminatória alenta o trabalhador tanto no momento da incorporação laboral como no seguimento da relação de trabalho, nos seguintes moldes:

I - Na inserção laboral exige-se a igualdade de oportunidades no acesso aos postos de trabalho e,

II - No seguimento da relação laboral, o trabalhador não pode padecer tratamento discriminatório ilegítimo e injustificado nas condições laborais e na prestação de serviços.

A tutela antidiscriminatória baliza as relações laborais, aplicando-se antes, durante e na extinção contratual, constituindo-se em instrumento limite ao poder empresarial. Logo, deve-se plantear que a autonomia contratual, nesta seara, encontra limites impostos no âmago das próprias normas especiais de tutela (PASTOR, 1993).

Seguramente cabe ao poder público exterminar as manifestações discriminatórias. No entanto, não se deve olvidar que é na esfera particular onde ocorre a maioria das situações discriminatórias, fato que não pode passar in albis.

Deste modo, "no puede establecerse un derecho omnicomprensivo de sujeción del trabajador al interés empresarial, siendo, necesario equilibrar entre las obligaciones dimanantes del contrato para el trabajador y el ámbito de su libertad" (SALVADOR, 2005). Permissa venia, há uma limitação expressiva em relação aos comandos e diretrizes patronais, porquanto, tais prerrogativas empresariais deverão ajustar-se às balizas máximas de tutela ao trabalhador, em seus essenciais direitos.

Isto posto, é fundamental enfatizar que "las facultades organizativas empresariales se encuentran limitadas por los derechos fundamentales del trabajador, quedando obligado el empleador a respetarlos" (SALVADOR, 2005). Argumento que perfila a Drittwirkung dos direitos fundamentais. Recordando-se que em relação à autonomia da vontade, “(...) las facultades empresariales no constituyen derechos ilimitados y absolutos" (SALVADOR, 2005).

Por consequência, a liberdade que permeia à contratação trabalhista concede espaço à vedação de discriminação, aplicável nas relações privadas. Desta forma, as causas elencadas constitucionalmente e outras consideradas juridicamente relevantes no ordenamento jurídico brasileiro, constituem limites ao poder empresarial.

Ainda que se admita que as decisões empresariais para a contratação de trabalhadores se embasam em critérios dependentes apenas da vontade privada, deve-se considerar que a 
vedação à discriminação limitará a liberdade empresarial. Assim, observamos a seguinte dicotomia: a liberdade contratual do empresário e o direito do trabalhador a não ser discriminado e de ter respeitadas as suas prerrogativas, garantias e liberdades fundamentais (BOTÍA, 1993).

Logo, a tutela antidiscriminatória impera como limite ao poder empresarial, conforme analisar-se-á nas linhas que seguem.

\subsection{Vedação à discriminação na formação do vínculo trabalhista}

Antes da consolidação efetiva do vínculo empregatício, os potenciais contratantes vislumbram a delicada fase das tratativas prévias à sedimentação do contrato. Neste patamar, o problema deve ser observado sobre três aspectos que tornam ainda mais difícil o momento de acesso ao emprego para o coletivo em análise:

Primeiramente, constata-se com a posição de inferioridade, submissão e resignação da pessoa que atende a uma oferta de emprego.

Outro aspecto a ser analisado, pressupõe a liberdade para contratar do empresário, conforme os critérios que ele julgue necessários ao exercício das atividades de sua empresa. Sob estes argumentos, apesar dos requisitos objetivos que se apresentam em qualquer seleção, não se pode excluir a força subjetiva que se reflete na escolha do candidato ao emprego.

Sem embargo, tanto os critérios objetivos como os subjetivos podem trazer prejuízos de caráter discriminatório. Ilustrativamente, é corriqueiro a associação da homossexualidade à determinadas doenças de cunho sexual.

E por último, neste momento é muito difícil a detecção de discriminações, em razão das peculiaridades, particularidades e subjetividade que adornam as fases de escolha do candidato ao posto vacante.

Logo, associando-se todos os elementos subjetivos e as prerrogativas legitimadas pelo poder empresarial, na fase de acesso ao posto de trabalho, pode haver vínculo entre a não contratação do candidato ou candidata e algum elemento de discriminação, como a idade, orientação sexual, atributos físicos, et coetera. Sem embargo, como há uma liberdade de escolha por parte do empregador, consequentemente, dificulta-se a comprovação da existência de indícios discriminatórios.

Certamente, pairam enormes obstáculos para a identificação da situação como discriminatória, posto que, nesta fase, centra-se o elemento subjetivo de forma ampla e contundente. Infelizmente, durante o processo seletivo pode ocorrer a negativa em contratar o 
trabalhador ou trabalhadora em razão de sua orientação sexual, desde que, esta informação seja levada ao conhecimento do empregador / contratante ou agente responsável pela seleção; esta conduta é discriminatória e violadora da dignidade e da intimidade do trabalhador.

Concessa maxima venia, cabe ressaltar que apesar de o contratante poder utilizar-se de um número diversificado de métodos e procedimentos para selecionar o profissional mais capacitado para ocupar o posto de trabalho, a escolha deve pautar-se em aspectos estritamente laborais e relacionados à função a ser executada na estrutura empresarial. Os atributos e qualificações profissionais devem ser determinantes para o resultado da seleção, sem a análise de circunstâncias pessoais, alheias ao exercício efetivo da atividade laboral; indubitavelmente, os preceitos constitucionais pró́bem e desestimulam este tipo de comportamento.

Desta maneira, perguntas de caráter pessoal e familiar, que não possuam qualquer relação com a atividade a ser exercida, implicam em indícios discriminatórios, posto que tais questionamentos podem, em realidade, dissimular a real intenção do agente contratante ou responsável pelo processo seletivo, para averiguar a orientação sexual do candidato ou candidata.

Por outro lado, em nosso repertório jurisprudencial constam decisões que patinam entre a proteção ao trabalhador e a liberdade para contratar do empregador. Assim, a $2^{\mathrm{a}}$ Turma do Tribunal Superior do Trabalho rechaçou o apelo do Ministério Público do Trabalho da $20^{\mathrm{a}}$ Região/Sergipe que vislumbrava obstar que uma empresa consultasse os serviços de proteção ao crédito, órgãos policiais e o poder judiciário, antes de efetuar a contratação do trabalhador. A Turma do TST considerou, por unanimidade, que "as consultas não são fatores discriminatórios, e sim critérios de seleção de pessoal que levam em conta a conduta individual" (ÚLTIMA INSTÂNCIA, 23/02/2012).

O Ministério Público do trabalho, em seu recurso ao TST, alegou que a decisão do Tribunal Regional do Trabalho violara "os artigos $1^{\circ}$, inciso III, $3^{\circ}$, inciso IV, $5^{\circ}$, inciso X, da Constituição da República, e $1^{\circ}$ da Lei 9.029/1995, sustentando que a conduta da empresa é discriminatória" (ÚLTIMA INSTÂNCIA, 23/02/2012).

$\mathrm{Na}$ análise do caso, o ministro Renato de Lacerda Paiva, relator do recurso, enfatizou que os cadastros pesquisados pelo contratante são públicos e "não há como admitir que a conduta tenha violado a intimidade, a vida privada, a honra e a imagem das pessoas". E ademais, "não há como vedar ao empregador o acesso a cadastros públicos como mais um mecanismo de melhor selecionar candidatos às suas vagas de emprego" (ÚLTIMA INSTÂNCIA, 23/02/2012). 
De outro modo, em decisão recente, a juíza Mônica Ramos Emery, da 20ª Vara do Trabalho de Brasília, por ocasião da ação civil pública movida pela procuradora Valesca de Morais do Monte, do Ministério Público do Trabalho, decidiu pela proibição de uma Rede de Lojas de exigir certidão de antecedentes criminais dos candidatos às vagas ofertadas pela empresa, além da fixação de multa pertinente (ÚLTIMA INSTÂNCIA, 10/06/2012).

A proibição de discriminação no acesso ao emprego, ilustrativamente, constitui um limite ao poder empresarial, posto que a liberdade contratual e a autonomia da vontade devem observar os preceitos vigentes no ordenamento jurídico pátrio. Sendo assim, esta liberdade concedida aos empregadores para pactuarem os contratos laborais não é absoluta, encontrando fundamento e limites nas normativas vigentes.

Certamente, o candidato homossexual que se sentir prejudicado deve recorrer ao sindicato representativo de sua categoria, bem como ao Poder Judiciário e ao Ministério Público do Trabalho para que se iniciem investigações contundentes sobre o fato denunciado.

\subsection{Tutela à não discriminação no desenvolvimento da relação laboral}

Neste cenário, questiona-se o ajustamento harmônico do poder empregatício, em suas múltiplas prerrogativas e o respeito à intimidade à privacidade do trabalhador.

É coerente afirmar-se que o poder empregatício, máxime em suas múltiplas prerrogativas para o contratante empregador não deve ser vislumbrado como uma escusa para o empregador interferir na vida privada dos seus subordinados ou permitir que outros assim atuem. Por certo, o vínculo constituído encontra-se adstrito à esfera laboral e não pode direcionar-se a conteúdo íntimo, reservado, relacionado com a vida particular dos trabalhadores.

No curso do vínculo empregatício a discriminação pode ocorrer em relação aos salários, promoções e até mesmo com a utilização de comportamentos, práticas e linguagem violenta contra o empregado ou a empregada, como decorrência de sua orientação sexual.

Neste momento, a discriminação contra os homossexuais, habitualmente, manifestase através de assédio, chistes, desconfiança, isolamento, exclusão; ou seja, mediante comportamentos que expressam violência psicológica contra o trabalhador, propiciando consequências negativas para o empregado como estresse, depressão, temor em perder o emprego ou sofrer vexações pelos colegas de trabalho, superiores hierárquicos e terceiros.

A violência psicológica manifesta-se através de hostilidades verbais ou não verbais reiteradas em forma de hostigamento, insultos, ameaças, dominação, menosprezo, humilhações, 
coerção, isolamento, entre outros. Reproduz a criação de uma situação estressante e destrutiva, carregada de instabilidade, que não permite o livre desenvolvimento da personalidade da pessoa subjugada (HIRIGOYEN, 1998).

Em termos de perseguição discriminatória podemos citar uma decisão da Primeira Turma do TST manteve a condenação por danos morais da empresa Telemar Norte Leste S/A pela discriminação de uma operadora de telemarketing em razão de sua orientação sexual. $\mathrm{Na}$ ação a trabalhadora salientou uma série de vexações padecidas na relação trabalhista, sendo perseguida com alcunhas e expressões perniciosas por parte de seus supervisores (TST, $04 / 12 / 2012)$.

A trabalhadora ressaltou em sua ação que recebia tratamento diferenciados pelo fato de ser homossexual e, inclusive, padecia assédio moral e constrangimentos variados ante outros funcionários da empresa,

Para o Ministro Relator Hugo Carlos Scheuermann "ficou demonstrado o abuso de direito do empregador, com constrangimento e abalo moral da empregada."

Outra questão relevante diz respeito aos direitos associados para os casais do mesmo sexo. Ou seja, de modo corrente, as empresas obsequiam aos trabalhadores uma gama de vantagens que, em termos similares, são concedidas para o usufruto de seus companheiros, como por exemplo, os planos de assistência médica e o auxílio funeral. Defendemos que, igualitariamente, estes benefícios sejam ofertados ao companheiro ou companheira do trabalhador ou trabalhadora, incluindo-se os companheiros homossexuais, sem qualquer diferenciação discriminatória decorrente da orientação sexual.

\subsection{Vedação à discriminação na ruptura do vínculo trabalhista}

A extinção do contrato de trabalho também pode ser motivada pela orientação sexual do empregado ou empregada. Neste caso, o empregador pode romper o pacto por discriminação, mas exteriorizar uma ruptura voluntária, sem falta grave do trabalhador, sendo, portanto, aparentemente legítima nos moldes de nossa legislação trabalhista, posto que se encontra dentro de suas prerrogativas de organização empresarial.

Sendo assim, o empregador poderá, a qualquer momento, extinguir o pacto trabalhista do seu contratado, arcando com as responsabilidades econômicas pertinentes; o empregador 
não está obrigado a manter a continuidade do vínculo laboral ad eternum ${ }^{4}$. Nesta perspectiva, o que não se pode compreender como legítimo é a ruptura do pacto laboral pela vontade unilateral do empregador, fundamentada na homossexualidade do seu trabalhador ou trabalhadora.

Em idêntico sentido, cabe retaliar a existência de situações vexatórias, humilhantes, assediantes em contra do trabalhador ou trabalhadora homossexual, possibilitando a configuração do panorama discriminatório e a consequente responsabilização do empregador, nos moldes da lei 9.029/95.

O conjunto normativo pátrio pertinente a não discriminação nas relações laborais modela um sistema de tutela para excluir preceitos regulamentadores, cláusulas coletivas, os pactos individuais e as decisões unilaterais do empregador contratante que contenham discriminações adversas por razão de sexo, origem, estado civil, condição social, ideias religiosas ou políticas, orientação sexual, entre outros.

Da valoração conjunta de todos estes preceitos, determina-se, como infringente dos paradigmas legalmente fixados na normativa laboral de tutela, a dispensa motivada em alguma das causas de discriminação previstas na Carta Magna de 1988 ou nos demais corpos normativos. Deste modo, tutela-se a relação laboral contra os despidos que se fundamentem em alguma causa discriminatória que menoscabe ou vulnere os direitos fundamentais e as liberdades públicas do trabalhador (NEWTON, 2011).

Neste cenário, urge recordar que a discriminação em razão da orientação sexual do trabalhador ou trabalhadora não compreende apenas aqueles tratamentos pejorativos que se fundamentam na simples constatação do sexo da pessoa prejudicada. Engloba, igualmente, toda sorte de tratamento desvantajoso que se firme na concorrência de condições ou circunstâncias que mantenham uma conexão direta e inequívoca com a orientação sexual do indivíduo.

A dispensa do vínculo laboral é um instrumento fatídico para desvelar a conduta discriminatória. Sem embargo, não é a única forma de manifestação das práticas empresariais discriminatórias, "puesto que las condiciones de trabajo pueden sufrir modificaciones no justificadas, que obedezcan a móviles discriminatorios” (RUBERT, 2002, p.79).

Desta feita, a tutela antidiscriminatória norteia as situações de dispensa discriminatória e outras formas de manifestação ilegítima e discriminatória do poder empregatício (PEREZ DEL RIO, 1999, p.66).

\footnotetext{
4 Cabe frisar que em alguns momentos, o nosso ordenamento trabalhista limita o poder empregatício em relação ao rompimento do vínculo contratual, quando da existência de condições justificadoras da conservação do vínculo, as chamadas garantias provisórias e a estabilidade.
} 
Neste particular, torna-se importante colacionar a decisão da $7^{\mathrm{a}}$ Turma do Tribunal Regional do Trabalho da $2^{a}$ Região (São Paulo) que, em julgamento de Recurso Ordinário impetrado por um professor de Educação Física dispensado do vínculo empregatício, asseverou que "atitudes de discriminação ou preconceito do empregador, embora inaceitáveis, não asseguram ao empregado a permanência no trabalho, pois a garantia de emprego exige previsão expressa em lei ou norma coletiva" (JUSBRASIL, 01/12/2005).

No caso em questão, o docente asseverou que a sua dispensa derivou de fatores discriminatórios, "por ter uma fotografia publicada em revista dirigida ao público gay", peticionando ao órgão judiciário a sua reintegração às funções (JUSBRASIL, 01/12/2005).

A empresa defendeu-se, sustentando que houve uma exposição do professor e como consequência os pais dos alunos "entendiam que esse não seria um professor adequado para ministrar aulas de Educação Física" para crianças com idade entre 15 e 19 anos, o que resultou na dispensa do reclamante (JUSBRASIL, 01/12/2005).

Tendo perdido a causa na Vara Trabalhista, o docente recorreu ao Tribunal Regional do Trabalho / São Paulo. O relator do recurso, Juiz Luiz Antonio Moreira Vidigal, confirmou que,

(...) o pedido de reintegração não se acha fundado em espécie alguma de garantia de emprego que, como bem se sabe, exige previsão em dispositivo expresso de lei ou norma coletiva e tem por finalidade assegurar a subsistência da relação em situações especialíssimas da vida profissional.

(...) ao empregado, ao lado do direito à inviolabilidade da intimidade, da vida privada, da honra e da imagem conforme lhe assegura o inciso $X$ do artigo $5^{\circ}$ da Constituição Federal, situa-se o dever de zelar pela preservação dessa mesma imagem de modo a que suas ações da vida privada não produzam efeitos nocivos aos interesses do empregador e aos fins sociais do trabalho. (JUSBRASIL, 01/12/2005).

A $7^{\mathrm{a}}$ Turma do Tribunal Trabalhista decidiu, por unanimidade, negar a reintegração do discente ao posto de trabalho.

Corolário da construção legal antidiscriminatória, taxada na norma pátria de tutela, é que nestes casos exige-se que o trabalhador apresente indícios do caráter discriminatório da decisão ou conduta empresarial que julgar discriminatória e violadora dos fundamentais direitos trabalhistas.

Neste sentido, oportunamente, o Tribunal Constitucional Espanhol assinala que quem invoca a discriminação, deve ofertar algum indício racional fático como apoio ${ }^{5}$, refletindo fatos

5Ver Sentença do Tribunal Constitucional de 3 de diciembre de 1988, EDJ 1987/8989. 
dos quais resultem uma presunção ou aparência de discriminação ${ }^{6}$. Portanto, ademais da invocação do tratamento discriminatório, é necessário que se acredite a presença de circunstâncias que constituam indícios racionais da existência de um panorama ou um clima propício à disseminação da conduta discriminatória.

Corroborando o delineamento anterior, consta no repertório jurisprudencial do Tribunal Superior do Trabalho a manutenção da condenação de um Banco por assédio moral e dispensa discriminatória de "um gerente de agência devido a sua orientação sexual" (TST, 23/04/2009).

$\mathrm{Na}$ reclamação trabalhista, o autor "pediu a reintegração ao emprego ou a correspondente indenização (pela dispensa discriminatória, danosa e kafkiana, segundo seu advogado) e também reparação pelos danos morais e materiais decorrentes do assédio ocorrido no curso da relação de emprego". A defesa do Banco alegou que "O motivo da justa causa teria sido o descumprimento de normas da sua política de crédito e a liberação de recursos de forma incorreta, sem a devida análise ", e não a orientação sexual do empregado (TST, 23/04/2009).

Contudo, o bancário situa, na peça inicial, diversas situações de perseguição, assédio e ofensa por parte de seu superior hierárquico, sendo inclusive rotulado, em alguns de seus atos, como "atitude de afeminado" (TST, 23/04/2009).

Concretamente, a sentença de primeiro grau confirmou que,

\begin{abstract}
o banco não conseguiu provar os motivos da justa causa e condenou-o ao pagamento de indenização por danos moral e material no valor de R\$ 916 mil. Por entender inviável a readmissão do empregado, converteu-a no pagamento em dobro dos salários desde $o$ afastamento até o trânsito em julgado da ação, com base na Lei ${ }^{0}$ 9.029/1995, que proíbe a discriminação na relação de emprego e impede a despedida discriminatória, concedendo ao empregado o direito de optar entre a readmissão ou o recebimento em dobro do período de afastamento. No julgamento de recurso ordinário, o Tribunal Regional do Trabalho da $5^{\mathrm{a}}$ Região (BA) reduziu o valor do dano moral para $\mathbf{R} \mathbf{2 0 0}$ mil, mas manteve o pagamento em dobro dos salários até o trânsito em julgado da ação (TST, 23/04/2009).
\end{abstract}

Nesta situação, vislumbra-se a condenação da empresa por danos moral e material e o pagamento em dobro dos salários do empregado, com aplicação da lei 9029/95 que enfatiza a tutela antidiscriminatória na relação laboral.

Por outro lado, a tutela legal concedida não implica na imunidade destes trabalhadores em face ao poder disciplinar da empresa; seus incumprimentos contratuais seguem sancionáveis e perfeitamente puníveis com as sanções legitimadas pelo nosso ordenamento jurídico laboral, a advertência, a suspensão e a extinção contratual por falta grave, respaldadas pelo poder 
empregatício.

Por sua vez, recai sobre o empresário demonstrar que a sua atuação radicou-se em causas reais, estritamente relacionadas ao vínculo contratual e absolutamente estranhas à vulneração dos direitos fundamentais. Ademais, cabe aclarar a existência de uma causa disciplinar sólida e grave para justificar a declaração de procedência da decisão extintiva, caso o fundamento extintivo seja um deslize praticado pelo trabalhador.

Igualmente, a conduta discriminatória contra o trabalhador homossexual pode forçálo a se afastar da relação laboral, camuflando uma situação de comunicação voluntária de demissão pelo trabalhador, ou compeli-lo à prática de atos que possam ocasionar a ruptura contratual por falta grave, excluindo, desta forma, o ônus econômico do empregador, nos ditames impostos no art.482 da Consolidação das Leis Trabalhistas; estes perfis mascaram situações discriminatórias e fraudulentas, com vistas à burlar os mecanismos jurídicos de tutela aos direitos laborais por ocasião da ruptura do contrato de trabalho. Por óbvio, tais posturas fraudulentas e engenhosas clamam por severo rebate e pronta reprimenda em nossos Tribunais trabalhistas.

\subsection{Rechaço às práticas discriminatórias após o término do pacto laboral}

$\mathrm{Na}$ fase posterior ao contrato de trabalho, os atos discriminatórios podem ser praticados como retaliação pelo antigo empregador contratante.

Neste particular, importante relembrar a decisão do juiz Felipe Augusto Calvet, da $14^{\mathrm{a}}$ Vara do Trabalho de Curitiba, ao condenar uma empresa de consultoria jurídica de segurança a pagar uma multa ao Fundo de Amparo ao Trabalhador - FAT, "por elaborar e vender listas com candidatos a empregos com antecedentes criminais ou ações trabalhistas na Justiça", em face da ação civil pública e medida cautelar propostas pelo Ministério Público do Trabalho do Paraná (ÚLTIMA INSTÂNCIA, 17/05/2005).

A elaboração e repasse das "listas negras" constitui conduta que deve ser prontamente combatida pelos órgãos de tutela, posto representar comportamento ilegítimo do empregador, ao sancionar o antigo empregado que porventura tenha ingressado com reclamação ante o judiciário trabalhista em busca de seus direitos, também como desestímulo aos atuais trabalhadores da empresa para que não recorram ao Poder judiciário; ademais, tal prática menoscaba a proteção discriminatória plasmada na lei 9.029/95. 
Neste sentido, cabe reconhecer a proibição do empregador de transmitir dados nocivos ou informações privatísticas ou denigrentes sobre os antigos empregados, conforme os preceitos de tutela preconizados em nossa legislação laboral.

Em situações discriminatórias, neste contexto, o empregado poderá defender-se recorrendo diretamente ao Poder Judiciário, buscando os órgãos representativos da categoria e o Ministério Público do Trabalho.

Percebe-se que existe um emaranhado normativo, tanto com o reconhecimento dos instrumentos internacionais como nacionais, que protegem as relações laborais contra as condutas discriminatórias praticadas na fase preliminar à formação do vínculo laboral, no curso do vínculo empregatício e após a ruptura do mesmo, independentemente do motivo que ensejou o término da relação laboral.

\section{Reflexões finais}

Conforme o anteriormente exposto, em território brasileiro, diversos são os mecanismos efetivos de tutela aos trabalhadores que permeiam as várias fases da relação laboral. Partindo-se da Carta Magna de 1988, consubstanciando-se com os parâmetros traçados pela lei 9029/95, seguindo até o conjunto protetor compilado no seio da Consolidação das Leis Trabalhistas, resguardam-se os fundamentais direitos dos trabalhadores.

Contudo, soçobra a sistemática tutelar concebida caso não se sedimentem, diuturnamente, reflexões, investigações e debates para a defesa e a promoção das garantias e direitos instituídos. Os condicionantes jurídicos, com ênfase na diversidade, carecem de uma eficaz propalação e conscientização dos meios antidiscriminatórios legalmente consagrados.

Em qualquer sociedade, cobiçar desenvolvimento, em suas múltiplas facetas, implica em debelar estereótipos, estigmas e máculas, tradicionalmente arraigados nas culturas de povos e Estados.

Nos cabe, portanto, vaticinarmos um horizonte no qual os estigmas e as matizes discriminatórias sucumbam, prostrados, ante às máximas fundamentais do respeito às diferenças. Legem habemus.

\section{Referências bibliográficas e sítios web}

\section{a) Referências bibliográficas}


BOTÍA, Alberto Cámara. Poder del empresario y prohibición de discriminación en el empleo. Revista del Ministerio de Trabajo y Asuntos Sociales, MTAS, 33.

BRASIL. Lei 9029, de 13 de abril de 1995, proíbe a exigência de atestados de gravidez e esterilização, e outras práticas discriminatórias, para efeitos admissionais ou de permanência da relação jurídica de trabalho.

CONVENÇÃO nº 111 da OIT, de 1958, sobre a discriminação em matéria de emprego e ocupação.

DECLARAÇÃO da Organização Internacional do Trabalho relativa aos princípios e Direitos Fundamentais no trabalho, adotada na $86^{\mathrm{a}}$ sessão da Conferência Internacional do Trabalho, em junho de 1998.

DECLARAÇÃO DE FILADÉLFIA. Declaração relativa aos fins e objetivos da Organização Internacional do Trabalho, adotada pela Conferência Geral da Organização Internacional do Trabalho, em 10 de maio de 1944.

HIRIGOYEN, Marie-France. El acoso moral. El maltrato psicológico en la vida cotidiana. Barcelona: Paidós, 1998.

JUSBRASIL. Notícias jurídicas. Opção sexual não garante estabilidade a empregado. 1 de dezembro de 2005. Disponível em:http://www.jusbrasil.com.br/noticias. Acesso em: 10 de maio de 2017. Ver RO 02237.2000.482.02.00-6.

MERINO, Julia Sevilla. Igualdad de Mujeres y Hombres a la Luz del Tratado de Amsterdam. Seminario celebrado en Madrid los días 13 y 14 de febrero de 2000. MTAS. Madrid: Instituto de la Mujer, 2001.

NEWTON, Paulla Christianne da Costa. Medidas de protección e inserción sociolaboral de las mujeres víctimas de violencia de género en el seno de la pareja. Valencia: Tirant Lo Blanch, 2011. 
PASTOR, María Amparo Ballester. Discriminaciones por razón de sexo en el acceso al empleo. Relaciones Laborales, número 3-4, 1993.

. Diferencia y discriminación normativa por razón de sexo en el orden laboral.

Valencia: Tirant Lo Blanch, 1994.

; BALLESTER CARDEL, María. Capítulo primero. Significado general y conceptual de la Ley Orgánica para la igualdad efectiva de mujeres y hombres. En: SALA FRANCO, Tomás; BAÑÓ LEÓN, José María; EMBID IRUJO, José Miguel; GOERLICH PESET, José María. (Coordinadores). Comentarios a la Ley Orgánica 3/2007, de 22 de marzo, para la IGUALDAD EFECTIVA de MUJERES y HOMBRES. Madrid: LA LEY, 2008.

PÉREZ CONTRERAS, María de Montserrat. Derechos de los homosexuales. Serie Nuestros Derechos. Cámara de Diputados. LVIII Legislatura. México: Universidad Nacional Autónoma de México. 2a Edição, 2001.

PEREZ DEL RÍO, Teresa. La Ley 39/1999 de conciliación de las responsabilidades familiares y profesionales: temas de debate. Temas Laborales, n. 52, 1999.

RODRIGUEZ-PIÑERO, Miguel; FERNANDEZ LOPEZ, María Fernanda. Igualdad y Discriminación. Madrid: Editorial Tecnos, 1986.

RUBERT, Maria Belén Cardona. Protección de la Trabajadora Embarazada: Tutela Preventiva y Tutela Antidiscriminatoria. Navarra: Editorial Aranzadi, 2002.

SAENZ DE MIERA, C. A.; RANZ PERIAÑEZ, E. Igualdad y no discriminación en las relaciones de trabajo. Em: (Autores Vários). II jornadas Hispano-Luso-Brasileñas de derecho del trabajo. Madrid: Ministerio del Trabajo y Asuntos Sociales, 1985.

SÁEZ LARA, Carmen. Mujeres y mercado de trabajo. Las discriminaciones directas e indirectas. Madrid: CES, 1994. 
SALVADOR, Belén Villalba. Comentarios a la sentencia del Tribunal Constitucional de 4 de julio de 2005: los derechos fundamentales como límite de las facultades organizativas empresariales. Revista de Derecho Social 31/2005. Ed Bomarzo, 2005.

TOMEI, Manuela. Análisis de los conceptos de discriminación y de igualdad en el trabajo. Em: Revista Internacional do Trabalho. Organização Internacional do Trabalho, vol. 122, núm.4, 2003.

TST - Tribunal Superior do Trabalho. Agência de notícias. Assessoria de Comunicação Social - TST. TST Telemar indenizará operadora discriminada por ser lésbica.4 de dezembro de 2012. Taciana Giesel. Disponível em: www.tst.jus.br. Acesso em: 13 de maio de 2017.

TST - Tribunal Superior do Trabalho. Agência de notícias. Assessoria de Comunicação Social - TST. TST rejeita recurso do Bradesco contra condenação por dispensa discriminatória. 23 de abril de 2009. Carmem Feijó. Disponível em: http://www.tst.gov.br/. Acesso em: 4 de maio de 2017. Ver RR 1019/2004-024-05-00.8.

ÚLTIMA INSTÂNCIA. Critérios de seleção. Empresa pode consultar SPC, Serasa e órgãos de polícia antes de contratar, decide TST. De: 23/02/2012. Disponível em: www.ultimainstancia.uol.com.br. Acesso em: 05 de abril de 2017. Ver RR-3810027.2003.5.20.0005.

ÚLTIMA INSTÂNCIA. "Nada consta". Lojas Renner não podem exigir certidão de antecedentes criminais de trabalhadores. De: 10/06/2012. Disponível em: www.ultimainstancia.uol.com.br. Acesso em: 05 de abril de 2017.

ÚLTIMA INSTÂNCIA. Empresa terá de pagar multa de $R \$ 100$ mil por vender lista negra. De: 17/05/2005. Disponível em: www.ultimainstancia.uol.com.br. Acesso em: 05 de maio de 2017.

VAINFAS, Ronaldo. Homoerotismo feminino e o Santo Ofício. Em: DEL PRIORE, Mary. História das mulheres no Brasil. São Paulo: UNESP, 2007.

\section{b) Sítios web}


http://portal.trt1.jus.br/

http://www.conjur.com.br/

http://ultimainstancia.uol.com.br/

http://www.jusbrasil.com.br/noticias

http://www.tst.gov.br/

http://www.trt5.jus.br/

http://mg.trt.gov.br/

http://www.trt10.jus.br/ 


\title{
MODERNIZAÇÃO E FLEXIBILIZAÇÃO DAS LEIS TRABALHISTAS: TELETRABALHO E O TRABALHO INTERMITENTE
}

\author{
Lucas Baffi Ferreira Pinto \\ Feso / Uva / Facha \\ Jorge Heleno Costa \\ Fumec / Uniptan
}

\section{Resumo}

As relações sociais e outras manifestações individuais e coletivas modernas sofrem constantes mutações, sendo certo que tais manifestações são perceptíveis no mundo do trabalho. No presente trabalho, a partir de análise bibliográfica (livros, artigos e demais escritos), se propõe a discutir a modernização e a flexibilização das leis trabalhistas, especialmente a partir do teletrabalho, do trabalho intermitente. Além disso, como pano de fundo do debate proposto, será discutida a questão da negociação coletiva e a intervenção estatal, a partir da liberdade e autonomia das partes envolvidas nessa relação.

Palavras-chave: Modernização, Flexibilização, Teletrabalho, Trabalho Intermitente, Negociação Coletiva.

\section{Abstract/Resumen/Résumé}

Social relations and other modern individual and collective manifestations are constantly mutated, and such manifestations are perceptible in the world of work. In the present work, based on bibliographical analysis (books, articles and other writings), it proposes to discuss the modernization and flexibilization of labor laws, especially from teleworking, from intermittent work. In addition, as the background to the proposed debate, the issue of collective bargaining and state intervention will be discussed, based on the freedom and autonomy of the parties involved in this relationship.

Keywords/Palabras-claves/Mots-clés: Modernization, Flexibilization, Teletrace, Intermittent Work, Collective Bargaining. 


\section{Introdução}

Em um ambiente tecnologicamente avançado como o que vivemos, as atividades produtivas, as relações sociais e outras manifestações individuais e coletivas modernas sofrem constantes mutações.

Não conseguimos prever, em geral, as mudanças que estão por vir, nem seus reflexos nas distintas esferas sociais. No entanto, é perceptível sua repercussão na vida social e, especialmente, no âmbito da relação de trabalho. Podemos citar, a título de exemplo, o caso do arcabouço tecnológico existente e sua repercussão nas relações de trabalho, gerando extinção, supressão e transformação de profissões mundo a fora.

Ocorrem várias inovações na vida das pessoas, crescentes progressos, como a robótica, as telecomunicações e a automação. Entretanto, o contexto atual revela-se paradoxal, nesta era da terceira revolução industrial. Ao invés de melhorar a qualidade de vida dos trabalhadores e gerar tempo livre, o que observamos é o crescimento desenfreado no número de desempregados. Um cenário crítico se torna presente e atinge países como o Brasil, o Terceiro Mundo, e até mesmo os países capitalistas centrais. Este processo - para alguns considerado destrutivo e gerador de precarização do trabalho e aumento do desemprego - é uma das consequências da crescente concorrência internacional e da busca por produtividade a qualquer custo.

O desemprego é um fenômeno em expansão. Como consequências diretas podemos destacar a desmoralização dos trabalhadores, o desperdício dos meios de produção, o enfraquecimento dos sindicatos e a sobrecarga dos programas de seguridade social.

Questiona-se, atualmente, as mudanças nos limites físicos da empresa, especialmente pela facilidade de comunicação, troca de informação, etc. Isso porque os empregados, em diversas situações, não estão mais limitados ao trabalho na empresa, como ocorria no passado. Antigamente o empregado que trabalhava numa linha de produção, tinha um trabalho mecânico, braçal, repetitivo.

Hoje, percebemos que esses mesmos empregados controlam a produção em um painel digital, conectado ao sistema interno, que envia relatórios de forma on line para o controle de uma equipe que pode estar em outro continente.

Faz-se necessária a presente introdução é necessária, pois o presente trabalho vai abordar a questão da moderninação da legislação trabalhista e a influência das novas tecnologias a partir da regulamentação do teletrabalho, bem como a flexibilização do Direito do Trabalho e a nova regulamentação do trabalho intermitente, especialmente a luz das 
mudanças promovidas pela Lei 13.467 de 2017. Outro ponto que será destacado, em menor incidência, é a figura do acordo entre empregador e empregador para extinção do contrato, uma vez que, além de prever algo que já vinha sendo praticado há décadas, trouxe um elemento civilista contratual para o contrato de trabalho neste aspecto.

A intervenção estatal e sua possível redução, bem como as reflexões acerca da valorização da negociação coletiva já foram objetos de outros trabalhos científicos.

Em outras palavras, o presentre trabalho propõe um debate sobre a modernização, flexibilização e regulamentação das leis trabalhistas, a partir dos institutos do (i) teletrabalho como reflexo do avanço tecnológico e dos seus efeitos nas relações de trabalho; (ii) contrato de trabalho intermitente, como exemplo de flexibilização da lei trabalhista, ao permitir a contratação do trabalhador "quando o empregador precisar", mitigando a assunção dos riscos, bem como (iii) discussão sobre a flexibilização e a negociação coletiva a partir da intervenção estatal.

Destaca-se de forma breve, a análise do acordo para extinção do contrato de trabalho entre empregado e empregador, previsto no art. 484-A da CLT, como um novo instituto regulado por lei, mas que vinha sendo praticado há décadas por trabalhadores e empregadores.

Diante desses pilares, vamos nortear a discussão ao longo do presente artigo.

Alguns questionamentos serão respondidos ao longo do desenvolvimento. O trabalho intermitente foi criado pela reforma trabalhista ou a nova lei regulamentou e grantiu diversos direitos a diversos trabalhadores que já estavam submetidos a regimes muito parecidos, mas não estavam amparados pelo ordenamento jurídico? O mesmo ocorreu com o acordo rescisório e outros pontos alterados recentemente?

Além disso, busca-se uma reflexão se a reforma trabalhista, recentemente aprovada, se mostrou adequada para resolver alguns problemas apontados pelos defensores de um Dirieto do Trabalho menos rígido e mais fléxivel e adaptável às relações sociais atuais.

Reforçando o que foi mencionado anteriormente, será abordado o fato da Lei 13.467 de 2017 ter regulamentado certas práticas que já vinham acontecendo nas últimas décadas, como o caso do acordo rescisório e a figura do trabalho intermitente ${ }^{1}$.

Apesar deste não ser o foco do presente trabalho, o pano de fundo da investigação aqui proposta é a necessidade ou não de flexibilização ou modenização das leis trabalhistas, tendo em vista as transformações ocorridas no mundo do trabalho. Além disso, chamamos atenção

\footnotetext{
${ }^{1}$ Agora esta modalidade de contratação faz jus aos direitos trabalhistas garantidos aos demais trabalhadores, o que não ocorria antes com os trabalhadores que faziam "bico".
} 
para a demora da legislação em regulamentar determinadas práticas comuns, como é o caso do acordo para extinção do contrato de trabalho.

Para fomentar a discussão, abordaremos a negociação coletiva e sua relação com a redução do intervencionismos estatal da relação de trabalho.

O tema estudado faz parte da pesquisa desenvolvida num grupo de pesquisa (integrado por mestrandos e doutorandos) sobre os impactos da modernidade no mundo do trabalho, especialmente a partir da globalização e do avanço tecnológico e necessidade ou não de flexibilizar determinadas normas que regulam esta relação entre empregado e empregador.

A tecnologia, dessa forma, ao encurtar as distâncias e proporcionar mutações das relações sociais, desencadeou significativas mudanças na relação entre empregado e empregador, especialmente no que diz respeito ao ambiente laboral.

Nesse contexto, no presente artigo vamos apresentar algumas considerações sobre o meio ambiente de trabalho, a modernização, a flexibilização e os reflexões do avanço tecnológico ao longo do desenvolvimento.

Para que sejam alcançados os objetivos propostos, a metodologia utilizada é a pesquisa bibliográfica, a partir referenciais teóricos já analisados e disponibilizados em meios escritos e eletrônicos, como artigos científicos, livros, páginas de web sites, bem como a pesquisa documental que recorre a fontes mais diversificadas e dispersas.

Começaremos pela análise do teletrabalho e a influência do avanço tecnológico, a partir da modernização das leis trabalhistas.

\section{Modernização das leis trabalhistas: e teletrabalho e as transformações sociais}

Percebe-se, hoje em dia, de um lado, um significativo avanço nos conhecimentos acumulados pelo homem em relação a evoluções tecnológicas, a natureza, etc., o que proporciona a capacidade de produzir-se bens e serviços de formas e em quantidades nunca antes vistas ou cogitadas. Em oposição a isso, a quantidade de indivíduos em todo o mundo que não tem acesso ao menos aos serviços básicos, quanto mais aos bens de consumo e passam por sérias dificuldades materiais é cada vez maior. Ainda para uma grande maioria das populações dos chamados países em desenvolvimento, que é o caso do Brasil, existe um problema muito mais sério do que se adquirir bens de consumo, duráveis ou não duráveis, estas pessoas têm dificuldades simplesmente de sobreviver dignamente.

Outro fator presente é o desemprego, que continua afetando as pessoas, especialmente no Brasil. Esta precarização não se submete às mesmas condições econômicas objetivas, não apresenta a mesma identidade social e não dispõe de recursos para assegurar a sua própria 
sobrevivência. Sua situação de precariedade e fragilidade penaliza, cada vez mais, suas chances de reinserção.

Diante desse panorama, questionamos se a legislação trabalhista que, historicamente, surgiu para criar o equilíbrio entre o capital e o trabalho, vem conseguindo exercer o papel de fiel da balança na relação entre o poder econômico e a hipossuficiência dos trabalhadores? ${ }^{2} \mathrm{~A}$ tutela rígida do Direito do Trabalho tem se mostrado eficiente no combate aos abusos cometidos pelos empregadores?

Neste item, abordaremos do teletrabalho e sua atual regulamentação (o que chamamos no caso do teletrabalho de modernização, por conta da influência tecnológica), a partir da Lei 13.467/2017. Como se sabe, a chamada reforma trabalhista buscou legalizar algumas práticas que já vinham sendo adotadas por várias empresas e profissionais.

O assunto aqui pesquisado é atual, pois com a aprovação de mecanismos de ampliação das leis trabalhistas, tais como a terceirização, o trabalho intermitente e o teletrabalho, surge em pauta a questão da precarização do trabalho, assunto que gera polêmica e discussão no âmbito acadêmico.

O teletrabalho, que pode também ser conhecido como trabalho home office, jamais seria possível sem a globalização. Dessa forma, os avanços tecnológicos foram fundamentais para criação e expansão dessas novas modalidades de trabalho. É por esse motivo que se tornou mais fácil realizar o trabalho fora da empresa, uma vez que qualquer pessoa, mediante a utilização de tecnologia, pode laborar de sua própria casa.

Ante o atual cenário mundial e, especialmente, brasileiro, é necessário refletirmos sobre os impactos que reforma trabalhista, recentemente aprovada, trouxe nesse aspecto.

Nesse sentido, em nota técnica, a ANAMATRA, com mais seis entidades trabalhistas emite o seguinte posicionamento:

\begin{abstract}
Da mesma forma, o teletrabalho, que poderia representar, no mundo tecnológico de hoje, uma modalidade de trabalho atrativa e interessante para o trabalhador, tal como colocada, se apresenta como mais um instrumento de flexibilização da relação de trabalho sem contrapartida, de transferência do risco da atividade para o trabalhador, e em síntese, de retirada e sonegação de direitos. (LIMA, 2018, p. 47)
\end{abstract}

Por conter tantas vantagens e desvantagens, todo trabalho incluído no gênero à distância (neste caso, o teletrabalho) deve ser regulamentado oferecendo-se garantias concretas,

\footnotetext{
${ }^{2} \mathrm{O}$ questionamento é pertinente, pois ao longo do estudo no grupo de pesquisa, percebe-se que somente a rigidez das normas trabalhistas não tem se mostrado suficiente para proteger os empregados de eventuais abusos cometidos pelos empregadores. Em matéria de direito do trabalho, nosso país está muito avançado em comparação com outras nações, no sentido de que nosso trabalhador possui muitos direitos trabalhistas. Porém, isso reflete nas condições de vida do trabalhador, na garantia do emprego? Apenas no intuito de fomentar o debate sobre o tema, questiona-se o fato da rigidez das leis trabalhistas acabar prejudicando o mundo do trabalho.
} 
tanto ao trabalhador quanto ao empregador, pois é certo que a tecnologia e a globalização criam situações novas, não pensadas pelo direito, por isso cabe ao legislador organizar esses pensamentos de forma prática buscando a ponderação de valores que melhor atenda e garanta a máxima efetividade dos direitos fundamentais e trabalhistas.

Assim, diante da dificuldade no exercício prático de se deslocar da residência para o trabalho, bem como custos para manter toda uma estrutura para receber o trabalhador, a melhor opção para esse senário seria que o trabalhador pudesse realizar suas tarefas do local que lhe garante mais qualidade de vida, qual seja, sua própria residência.

Vantagens a parte e não há como negar os inúmeros pontos positivos, faz-se necessário observar também alguns aspectos negativos em relação ao assunto, a saber, a dificuldade na detecção da subordinação jurídica, a dificuldade para o trabalhador de separar a vida pessoal da vida profissional, a dificuldade em adaptar-se a um novo emprego, além de limitar o convívio profissional do teletrabalhador.

De toda sorte, ultrapassadas as questões relacionadas aos benefícios e malefícios do teletrabalho, conforme já mencionado acima, o teletrabalho pode ser entendido como aquele realizado para o empregador fora do ambiente da empresa, podendo ser na própria residência do empregado. Consiste, basicamente, na prestação de serviços à distância, mediante a utilização de tecnologia.

Após tal análise, reforçarmos a importância da legislação de uma forma geral, importando-nos a legislação trabalhista, atualizar-se frente às constantes trabsformações. $\mathrm{O}$ teletrabalho se apresenta como um exemplo da influência dos avanços tecnológicos na relação de trabalho. O legislador ordinário da CLT deveria prever tal situação? Defendemos que a resposta é não, uma vez que a revolução tecnológica é posterior. Dessa forma, a modernização da legislação é necessária, especialmente por conta das transformações sociais, econômicas, tecnológicas, etc.

No próximo capítulo, trataremos da flexibilização a partir da negociação coletiva, que foi, de certa forma, valorizada após as recentes mudanças.

\section{Flexibilização e a negociação coletiva}

Apesar de percebermos na doutrina e na jurisprudência uma forte resistência de flexibilizar, deixar menos rígido o ordenamento jurídico trabalhista, as transformações sociais indicam que o mundo do trabalho nos dias atuais é diferente, em comparação com o período de criação da CLT, na década de 40, por exemplo. 
Vamos tecer algumas considerações sobre o pano de fundo do debate, em sentido amplo, envolvendo a flexibilização e a negociação coletiva.

A negociação coletiva se apresenta como uma solução para reequilibrar essa relação entre empregado e empregador? As recentes mudanças ocorridas indicam para uma possível retomada da privatização do direito do trabalho, ainda que se forma sutil, diante da fragilidade da parte trabalhadora. Tal assunto, apesar de não ser o foco do presente trabalho, é importante para analisarmos a flexibilização a partir da ampliação da negociação coletiva. Este assunto será analisado com mais detalhes no item seguinte, ao falarmos da intervenção estatal na relação de trabalho e a importância da valorização da negociação coletiva.

O ordenamento jurídico brasileiro autoriza a negociação entre os agentes da relação trabalhista, sendo certo que tal diálogo é controlado e subordinado a uma legislação que tenta prever as necessidades e demandas da sociedade.

Seguindo este pensamento, Maurício Godinho afirma ao tratar do modelo da "normatização privatística subordinada" que o modelo de intervenção estatal

\begin{abstract}
caracteriza o padrão de normatização privatística mas subordinada não substitutivo ou impeditivo da criatividade e dinamismo privados, mas condicionador dessa criatividade. Nesse quadro, o intervencionismo, embora inquestionável, admite claramente a franca e real participação da sociedade civil na elaboração do Direito do Trabalho. Em função dessa combinação de esferas de atuação, o modelo tende a gerar uma legislação que reflete, com grande aproximação, as necessidades efetivas dessa sociedade (DELGADO, 2016, p.106).
\end{abstract}

A partir desta referência, percebe-se que o modelo da normatização privatística subordinada foi adotado por governos fascistas, no período pós primeira Guerra Mundial, especialmente na Itália e Alemanha, e influenciou consideravelmente o modelo brasileiro na época da criação da $\mathrm{CLT}^{3}$. Cabe indagar se este modelo, que influenciou a CLT e demais normas impostas durante o regime militar da época, está superado e precisa de uma reformulação.

Neste item será abordada a questão da flexibilização, especialmente à luz da recente Lei 13.467 de 2017, analisando a necessidade (ou não) de mudanças legislativas para adaptação da legistação trabalhista às mudanças promovidas pela modernidade e pelo avanço tecnológico nos últimos tempos.

\footnotetext{
${ }^{3}$ Reconhecemos que tal entendimento não é majoritário na doutrina nem na prática trabalhista. Ao longo da pesquisa e, especialmente, durante congressos e eventos sobre o tema, percebe-se que diversos pesquisadores e profissionais que atuam neste ramo, rechaçam essa ligação entre a legislação Italiana e a CLT. Porém, autores do presente trabalho entendem pela influência do governo brasileiro à época da criação da CLT.
} 
Em geral dizemos que há crise quando nos encontramos diante de uma situação que não nos satisfaz ou que nos prejudica. O Brasil é um país, que dentre muitos outros, vem sendo afetado pelos efeitos negativos de uma crise econômica. Os efeitos mais graves de uma crise são: a ameaça constante do fechamento de empresas e consequentemente o elevado número de desempregados.

Isso ocorre por que em nosso país, mesmo com a globalização e com toda tecnologia utilizada o custo da produção no Brasil ainda é muito alto, podendo destacar o custo da mão de obra, a carga tributária brasileira, além de problemas de infraestrutura e segurança, que acabam afetando a atividade pdodutiva e aumentam o custo de produção, tornando o Brasil menos competitivo no mercado globalizado.

Dessa forma, o direito deveria acompanhar tais mudanças e adaptações a um novo senário econômico, mas, sem deixar de garantir as necessidades de desenvolvimento humano do trabalhador. No caso do presente trabalho, limita-se a necessidade de garantia das condições de trabalho dos empregados.

Neste contexto, surge a proposta de "flexibilização das normas trabalhistas" como uma das soluções para enfrentar essa problemática. Seria a forma de amenizar o rigor das normas trabalhistas e a rigidez proporcionada à relação entre empregador e empregado?

Propomos no presente artigo, considerando o momento atual, uma reflexão acerca da necessidade de flexibilização, sem que isso signifique retirar a proteção ao trabalhador. Tais mudanças devem ser feitas para minimizar a intervenção do estado em certas normas trabalhistas que poderiam ser negociadas individualmente ou coletivamente, como vem sinalizando a legislação trabalhista.

Não há avanço e melhora na qualidade de vida sem crescimento econômico, porém este crescimento não pode ocorrer distante da dignidade do trabalhador. Defendemos que nossa legislação deveria ter sido atualizada, especialmente por conta dos avanços tecnológicos, eis que as relações de trabalho foram modernizadas e não são mais as mesmas do século passado.

Nesse ponto específico podemos destacar a mudança legislativa no sentido de valorizar a negociação coletiva, limitando a atuação do Poder Judiciário e, priorizando assim, a melhoria das políticas de mercado de trabalho, além da redução do assistencialismo estatal que, em grande escala, prejudica o crescimento e a diversificação econômica. Apesar das recentes mudanças terem retirado parte significativa das receitas dos sindicatos, reforçou seu poder/dever de negociação coletiva.

Questiona-se o seguinte: será que a flexibilização é um caminho sem volta? Muitos profissionais reclamam a continuidade de leis rígidas, mas será que as mudanças decorrentes 
dessa crise seguirão firmemente? Cabe ressaltar que, em um cenário ideal, a flexibilização anda de mãos dadas com a segurança, onde o foco não é a conservação do emprego, mas sim a possibilidade de obter nova colocação.

A rigidez da legislação trabalhista advém da luta de classes e, por esse motivo, a intervenção do Estado foi necessária para uma elaboração de leis protecionistas a fim de condicionar as partes a buscar o Estado para dirimir os seus conflitos, pois o Direito do Trabalho nasceu em época de prosperidade econômica para os empregadores. Nesse tempo, a debilidade econômico-social do empregado merecia ser compensada com uma superioridade jurídica, balanceando assim as infinitas diferenças entre as partes dessa relação.

Por ocnta das transformações ocorridas pela globalização e pelo avanço tecnológico, O Direito do Trabalho passou a ser questionado. Sustenta-se ultrapassada a distância tão infinita entre empregado e empregador, e a flexibilização vem para restabelecer esse equilíbrio. Nesse sentido busca-se, a flexibilização do contrato de trabalho e com mais segurança no mercado de trabalho. Em outras palavras, garantindo maneiras mais simples e baratas de contratos de trabalho, teremos mais contratos sendo realizados.

Se utilizada de forma prudente e sem aniquilar princípios pilares do direito do trabalho, é possível falar de flexibilização sem que isso implique em supressão de direitos, sendo este o principal desafio do legislador.

Aliado a isso, no item seguinte será abordada a questão da intervenção estatal e o seu papel na relação entre empregado e empregador. É possível afirmarmos que houve maior liberdade e autonomia nas relações de trabalho a partir da lei 13.467/2017?.

\subsection{Liberdade e autonomia nas relações de trabalho}

Parece-nos que a resposta formulada no fim do capítulo anterior é positiva. O legislador tentou imprimir maior autonomia e liberdade à relação entre trabalhador e empregador, promovendo uma espécie de oxigenação da relação que sofre forte intervenção estatal nas regras que regulam esta relação. Dentre as formas de flexibilizar normas trabalhistas, a negociação coletiva se apresente como uma possível saída, mas neste contexto, será que a primazia da negociação coletiva veiculada pela reforma trabalhista, ocorreu num momento adequado? A criação do trabalho intermitente será uma das soluções para combater a crise do desemprego ou será uma nova forma de precarização formal de direitos trabalhistas?

Indaga-se, também, se os problemas debatidos atualmente no âmbito das relações de trabalho estão ligados ao papel intervencionista e protecionista do Estado nessa relação. De 
outro modo, tenta-se entender, se há necessidade da ampla tutela, intervenção e regulação estatal frente às relações entre empregado e empregador, sem imprimir juízo próprio favorável ou contra.

Ressalte-se, ainda, que apesar da atual Constituição Federal de 1988 adotar o estado democrático de direito, este regime se mostra incompatível com o intervencionismo paternalista autoritário das normas que regulam as relações de trabalho, especialmente as constantes na CLT e outras normas esparsas referentes às relações de trabalho.

Destaca-se o trecho abaixo acerca do suposto conflito entre o modelo intervencionista e a manifestação democrática na regulação das relações de trabalho, senão vejamos:

A aceitação do modelo intervencionista pelos destinatários resulta da inevitável imposição, e não de espontânea adesão. O grave é que os excessos intervencionistas do Estado geram frequentes manifestações de rejeição da norma, registrando-se sistemático e reiterado descumprimento, para clara e indesejável desprestígio da lei. (ROMITA, 2008, p. 48).

Verifica-se, dessa forma, que a principal característica do direito trabalhista brasileiro é a regulação heterônoma da relação entre empregado e empregador. Trata-se de legislação imposta por um agente externo, que neste caso é o Estado. Há pouca margem para a negociação e o diálogo entre as partes envolvidas, tendo a reforma trabalhista tentado modificar este quadro, ainda que de forma sutil.

Evidente que mudanças substanciais em regras já sedimentadas no ordenamento jurídico encontraria diversas formas de resistências, sendo perceptíveis mais de uma de uma forma de resistência, desde a que diverge pela questão interpretativa até a que se opõe às mudanças por questões ideológicas. A resistência pelo fator interpretativo é algo comum no mundo do direito, não ficando de fora o direito do trabalho ${ }^{4}$. Em momento algum abrimos espaço na presente pesquisa para o discurso político partidário. A presente investigação se limita à análise e discussão jurídica acerca das mudanças legislativas no âmbito do direito do trabalho ${ }^{5}$.

Ao analisarmos o nosso ordenamento jurídico, desde o seu surgimento no Brasil, este ramo do direito, busca afastar o caráter civilista contratual da relação entre empregado e

\footnotetext{
${ }^{4}$ Destaca-se o árduo trabalho da jurisprudência trabalhista na missão de pacificar a aplicação da lei e interpretar diversos dispositivos que geram interpretações que prejudicam a prática forense nos tribunais. As divergências interpretativas fazem parte do direito e são saudáveis para o debate e a construção do pensamento jurídico.

${ }^{5}$ Faz-se necessária esta ressalva, pois é de fácil percepção no debate público a resistência às recentes modificações promovidas pela reforma trabalhista pelo simples fato de ter sido aprovada por um governo de oposição ao partido político de preferência. Como dito acima, em momento algum o presente trabalho está relacionado com política partidária, seja quando defende, seja quando ataca as recentes mudanças. Não tomar este cuidado é acabar esvaziando a discussão jurídica, reduzindo o debate à esfera política e ideológica.
} 
empregador. Constata-se tal afirmação a partir da leitura do item 28 da exposição de motivos da comissão que organizou a CLT em 1943, deixando devidamente registrado o afastamento dessa concepção no que diz respeito à regulamentação do direito do trabalho no Brasil, que procura esclarecer que a precedência das "normas" de tutela sobre os "contratos" acentuou que a ordem institucional ou estatutária prevalece sobre a concepção contratualista" (exposição de motivos da CLT). ${ }^{6}$

Durante décadas, o ordenamento brasileiro foi marcado por seu caráter intervencionista do Estado, de modo que os mecanismos de negociação coletiva e a solução de tais conflitos desaguavam no Poder Judiciário. Caso as partes envolvidas não cheguem a um acordo, o Poder Judiciário as substitui e põe fim ao conflito, por meio de uma sentença normativa, resultado de um dissídio coletivo.

Diante dos fatos debatidos, destaca-se a importância do uso da negociação coletiva de forma prudente, não para suprimir direitos trabalhistas, mas para adequar realidades distintas que a lei geral e abstrata não consegue cuidar.

No próximo item, vamos falar de alguns aspectos recentes que trouxeram certa a regulamentação do trabalho intermitente, propondo o debate sobre a precarização ou não das condições de trabalho.

\section{O trabalho intermitente: precarização ou não?}

Num primeiro momento, parece não fazer muito sentido os três pontos destacados no presente trabalho, a partir do tema pesquisa. Porém, o intuito de propor a reflexão sobre estes pontos específicos se dá pelo fato do teletrabalho estar ligado à influência das novas tecnologias e do avanço tecnológico na relação de trabalho, sendo nossa hipótese de modernização da legislação.

Acerca da flexibilização, trouxemos o debate sobre a negociação coletiva e a intervenção estatal, a partir da liberdade e autonomia dos interlocutores, visando propor uma análise jurídica para as recentes mudanças e, em alguns pontos, sobre a sua necessidade e aspecto positivo.

Sem perder de vista o tempo do presente capítulo, o exemplo do contrato de trabalho intermitente parece-nos um bom exemplo de flexibilização das leis trabalhistas, de modo que,

\footnotetext{
${ }^{6}$ Pelos defensores das recentes mudanças promovidas pela reforma trabalhista, especialmente aqueles que defendem uma modernização das leis trabalhistas, a CLT, justamente por ser uma consolidação (junção) de leis esparsas, precisa de significativas mudanças, especialmente pelo fato do momento de sua criação ser distinto do momento atual enfrentado pelo Brasil, não só na esfera econômica, mas social, política, tecnológica, jurídica, etc.
} 
por esta modalidade de contrato, o empregador convoca o trabalhador quando precisa dos seus serviços, alternando tal convocação com os períodos de inatividade. Todavia, apesar da intermitência prevista, o trabalhador possui diversos direitos trabalhistas aplicáveis aos demais empregados, trazendo uma melhor condição para o grande número de trabalhadores que "fazem bico" em trabalhos informais como garçons, eventos em geral, atendentes, vendedores extras, etc.

Não podemos deixar de registrar, conforme anunciado, o fato da reforma trabalhista ter regulamentado algo que vem sendo praticado há décadas, como é o caso do acordo para extinção do contrato de trabalho. ${ }^{7}$ Analisaremos alguns aspectos desses pontos citados, especialmente a questão do trabalho intermitente, propondo uma discussão acerca da precarização ou não de tal modalidade de contrato.

A reforma trabalhista aprovada pela Lei ${ }^{\circ} 13.467 / 2017$, com vigência a partir de 11 de novembro de 2017, trouxe, dentre outras inovações, a modalidade de trabalho intermitente, conhecido na Inglaterra como trabalho zero hora. Sua regulamentação se deu mediante os artigos $443, \S 3^{\circ}$ e $452-\mathrm{A}, \S \S 1^{\circ}$ ao $9^{\circ}$ da CLT.

Pretende-se neste item apontar as características desta nova forma de contratação e principalmente seus impactos no mundo do trabalho. No Brasil, o objetivo foi superar a crise econômica, por meio da geração de empregos no país e tentar reduzir a informalidade de contrato de trabalho tido como "bico", trazendo para a formalidade estes trabalhadores.

Diante de alterações ocorridas na realidade social, em cuja base o direito do trabalho se assenta, também este deve mudar-se ou adaptar-se. Ante o atual cenário brasileiro, a reflexão sobre as inovações trazidas pela reforma trabalhista, entre elas a regulamentação do trabalho intermitente, torna-se, pois, necessária.

Os paradigmas do trabalho subordinado, com habitualidade, oneroso, e, geralmente, de tempo integral e por tempo indeterminado, são elementos estruturais da relação de emprego (contratação padrão) e que marcam este ramo excepcionado do direito. O nó estabelecido pela reforma trabalhista desata-se por uma nova forma de relação, caracterizando até uma possível mudança de paradigma. Abriu-se um quadro de eclipse nas normas de proteção, marca

\footnotetext{
${ }^{7}$ Em eventos que participamos ou em sala de aula perguntamos aos alunos quem conhece alguém que, antes da reforma trabalhista, já fez um "acordo" com o empregador para ser demitido e poder sacar o FGTS. Alguns casos, sabe-se que além do trabalhador simular a dispensa sem justa causa, devolvendo ao empregador a multa dos $40 \%$ do FGTS, recebe as parcelas do seguro-desemprego e, mesmo durante a sua percepção, começa a trabalhar, solicitando para seu empregador que assine a sua CTPS posteriormente, para que possa continuar recebendo o seguro-desemprego e o salário no seu novo emprego. Claro que não estamos generalizando tal conduta, mas não tão incomum como pode parecer e a físcalização de tais condutas ilícitas tem sido aprimorada nos últimos anos através de sistema integrado entre Receita Federal, Caixa Econômica, Previdência Social e outros órgãos envolvidos.
} 
registrada deste ramo do direito, que decorre, em grande parte, pela precarização de direito até então consagrado, com o surgimento desta ideia de romper a lógica, criando-se uma tipologia contratual que, mantido o vínculo de subordinação típico da contratação tradicional, permite a utilização descontínua do tempo de trabalho, com reflexos diretos sobre os ganhos oriundos do trabalho e na sua profissionalização.

Sob a bandeira da possiblidade de geração de novos empregos, com a criação do contrato de trabalho intermitente, a fratura já está exposta: alguns alegam que as empresas terão maior facilidade e flexibilidade na contratação de trabalhadores nesta modalidade e tenderá a reduzir o número de 14 milhões de desempregados; para outros trata-se de uma forma mascarada de emprego, com acentuada precarização de direitos trabalhistas, em cujo regime o trabalhador prestará o serviço de forma descontinuada, com alternância entre períodos ativos e inativos, obedecendo obedecer um espaço de tempo em horas, dias ou meses.

É o que se deflui do conceito estabelecido o art. 443 da CLT em seu parágrafo $3^{\circ}$, in verbis:

Considera-se como intermitente o contrato de trabalho no qual a prestação de serviços, com subordinação, não é contínua, ocorrendo com alternância de períodos de prestação de serviços e de inatividade, determinados em horas, dias ou meses, independentemente do tipo de atividade do empregado e do empregador, exceto para os aeronautas, regidos por legislação própria.

Esta alternância, para o empregador, é uma das principais vantagens da contratação de trabalho intermitente, porque atende a sua demanda, evitando-se, assim, a ociosidade em alguns contratos, o que reduz, dessa forma, os custos trabalhistas.

Vejamos alguns aspectos trazidos pela legislação própria (art. 452-A, $\S \S 1^{\mathrm{o}}$ ao $9^{\circ}$ da CLT) desse tipo de contrato, denominado intermitente.

A lei determina a forma escrita para essa modalidade de contrato, devendo ser consignado o salário hora ajustado, que não poderá ser inferior ao salário mínimo/hora, com anotação da CTPS (Art. 453-A). Entende-se que tal exigência constitui requisito formal para sua validade, ou seja, onde o trabalhador não tenha firmado o contrato escrito com os requisitos legais, restará caracterizado contrato de trabalho padrão, ou seja, contrato de trabalho subordinado por prazo indeterminado e a tempo pleno.

Estabelece também que o empregador deve convocar o trabalhador para prestação dos serviços por qualquer meio eficaz, informando qual a jornada com antecedência de pelo menos 3 (três) dias $\left(\S 1^{\circ}\right)$, bem como o prazo de um dia útil para que o empregado responda ao 
chamado, presumindo-se, do silêncio, a recusa $\left(\S 2^{\circ}\right)$. Referida recusa, contudo, não descaracteriza a subordinação para este específico tipo de contrato de trabalho $\left(\S 3^{\circ}\right)$.

Verifica-se que o empregado não está obrigado a aceitar a proposta de trabalho, podendo recusá-la sem necessidade de justificativa da recusa. O prazo de um dia útil para manifestar sobre a aceitação ou a recusa, pelo que se depreende do texto legal, deve ser contado a partir do momento em que o trabalhador recebe o convite.

Caso o trabalhador manifeste aceitação pela oferta de trabalho, se houver descumprimento, por qualquer uma das partes, sem justo motivo, deve pagar à outra parte, em 30 dias, multa de $50 \%$ (cinquenta por cento) da remuneração que seria devida, permitida a compensação em igual prazo $\left(\S 4^{\circ}\right)$.

Quanto a esta questão da multa imposta ao trabalhador na hipótese de aceite do chamado e não comparecimento ao trabalho sem qualquer justificativa, entende Nogueira (2017, p. 136-137) que caso não tenha havido outro chamado aceito no período de referência do pagamento
(trinta dias), quando se pudesse pensar em compensação (prevista na lei, embora
discutível), não poderia o empregado arcar com qualquer pagamento. Uma
intepretação possível do dispositivo seria a de que o empregador apenas pode cobrar
a multa do trabalhador no prazo de 30 (trinta) dias, e não além deste, já que o prazo é
fixado como prazo limite para possível compensação. Teríamos aqui um outro caso
de decadência previsto no direito do trabalho brasileiro.

Por fim, estabelece que o período de inatividade não será considerado tempo à disposição do empregador, podendo o empregado prestar serviços a outros contratantes $\left(\S 5^{\circ}\right)$.

Entende-se que o empregado não pode sofrer nenhuma limitação, seja em sua vida pessoal, seja em sua liberdade ampla e irrestrita de locomoção para que haja efetiva inatividade, ou seja, para que não se caracterize tempo à disposição.

Quanto aos pagamentos, deverão ser realizados, imediatamente, a cada período de prestação de serviço $\left(\S 6^{\circ}\right)$, devendo ser emitido recibo com a discriminação de cada importância paga $\left(\S 7^{\circ}\right)$.

Assim, ao final de cada mês, realiza-se o pagamento da remuneração, das férias proporcionais com acréscimo de um terço, do décimo terceiro salário proporcional, do repouso semanal remunerado e dos adicionais legais $\left(\S 6^{\circ}\right)$.

No tocante aos recolhimentos das contribuições previdenciárias e do depósito do Fundo de Garantia do Tempo de Serviço, determina que ficarão a cargo do empregador, com base mensal, fornecendo ao empregado o comprovante de tais recolhimentos $\left(\S 8^{\circ}\right)$. 
Outra inovação interessante em nosso Direito, com relação ao trabalho intermitente, é que após 12 meses de prestação de serviços para o empregador, o trabalhador fará jus ao gozo das férias, não podendo ser convocado neste período $\left(\S 9^{\circ}\right)$. Entretanto, o legislador eximiu o empregador de remunerar o período concedido, de modo que, o trabalhador fará jus a somente o período de descanso, sem o tradicional acréscimo de 1/3 salarial. Isto tem evidências de inconstitucionalidade, por violar frontalmente o disposto no art. $7^{\circ}$, XVII, da Constituição Federal de 1988, cuja tese, por uma interpretação sistemática, seria corroborada pelo art. 611-B, inciso XII, que inclui as férias anuais de trinta dias, remuneradas e acrescidas de 1/3, no rol dos direitos assegurados na Constituição, aos quais é vedada alteração via negociação coletiva.

Após esta visão mais aprofundada do contrato de trabalho intermitente, visto com uma das mudanças que promoveram a flexibilização das leis, à luz da reofma trabalhista, vamos tecer algumas considerações sobre o acordo para rescisão do contrato de trabalho, previsto no art. 484-A da CLT.

Conforme falado anteriormente, algo bem próximo da atual regulamentação já ocorria na prática. A lei alvo de críticas desenfreadas apenas trouxe para o texto legal uma prática que vinha ocorrendo há décadas.

Feita esta análise no último capítulo do trabalho, passemos às conclusões da presente pesquisa.

\section{Conclusão}

O tema é atual e polêmico e, sem esgotar o debate sobre tais aspectos, buscamos refletir no presente trabalho o direito do trabalho e as recentes mudanças, basicamente, a partir de três pilares elencados no artigo: (i) modernização das leis trabalhistas e o teletrabalho; (ii) a flexibilização, a negociação coletiva e a intervenção estatal, a partir da liberdade e autonomia e, por fim, (iii) o trabalho intermitente como precarização ou não das relações de trabalho.

Para alcançarmos os objetivos propostos, destacamos que a legislação trabalhista brasileira carece de modernização e atualização, especialmente pelas transformações ocorridas entre o período da CLT (e da maior parte das leis ordinárias) e o momento atual, décadas e décadas depois.

No intuito de propor a reflexão, o ponto central da discussão que permeia o debate no grupo de pesquisa é a necessidade de modernização/adaptação/ das leis trabalhistas às novas formas de trabalho e a forma como a tais mudanças foram feitas pela Lei 13.467 de 2017. 
Vimos o papel importante que a negociação coletiva pode desempenhar para preservar as especificidades de determinadas atividades, desde que respeitados os direitos trabalhistas já conquistados.

Outro aspecto relevante é a figura do teletrabalho e modernização das leis trabalhistas, tendo em vista as transformações causadas pelo avanço tecnológico nesta relação. Foram expostas algumas vantagens e desvantagens desta forma de prestação de serviço. Será que a reforma trabalhista, ao regulamentar esta modalidade, errou em todos os aspectos? O avanço tecnológico não chegou nas relações de trabalho? É evidente que chegou e, mais do que isso, modificou em alguns aspectos e a legislação deveria ter se atualizado.

No que diz respeito à flexibilização das leis trabalhistas e a intervenção estatal, podemos destacar que a legislação trabalhista rígida e inflexível acaba afastando as partes, dificultando o diálogo necessário para a negociação. É preciso dar uma pequena dose de liberdade e autonomia para as partes contratantes, devendo, sem dúvida, tais regras estarem sob fiscalização do Estado, coibindo práticas ilícitas e aplicando as penalidades devidas.

A ausência de autonomia e liberdade, por conta dos ideais paternalistas, que ainda rondam os princípios do direito do trabalho, acabam criando uma enorme distância entre empregado e empregador.

Outro ponto que merece destaque é que o trabalho intermitente, apesar de ser criticado, pode servir como instrumento de expansão dos direitos trabalhistas para uma parcela de trabalhadores que vivia de bicos, diárias e incertezas. Apesar do contrato de trabalho intermitente não trazer nenhuma garantia, o empregado pode celebrá-lo com mais de um empregador, recebe todos os direitos trabalhistas dos demais empregados, de forma proporcional às horas trabalhadas.

Não há dúvidas de que a flexibilização de normas trabalhistas pode ser uma das saídas para a crise econômica e retomada da competitividade no mercado, especialmente por conta do alto custo da mão de obra.

Por fim, conforma já mencionado, a época da criação da CLT é diferente do momento atual e a legislação deve ser ajustada a essas transformações de oito décadas. O problema é a forma como tal modernização foi feita, o que gerou ainda mais discussão.

Dessa forma, ressaltamos a importância de refletir sobre os temas pesquisados, especialmente pelo momento de constantes mudanças no âmbito do direito do trabalho. Cabe ao pesquisador do direito refletir sobre o cenário passado, aprender com os erros e auxiliar o auxiliar o legislador na busca do melhor caminho para reequilibrar a relação entre empregado e empregador. 


\section{Referências bibliográficas}

ANTUNES, Ricardo. Adeus ao Trabalho?: ensaio sobre as metamorfoses e a centralidade do mundo do trabalho. 7.ed.ver. ampl. São Paulo: Cortez; Campinas: UNICAMP, 2000.

\section{.SÉCULO XXI: NOVA ERA DA PRECARIZAÇÃO ESTRUTURAL DO}

TRABALHO?

http://www.fundacentro.gov.br/Arquivos/sis/EventoPortal/AnexoPalestraEvento/Mesa\%201 \%20-\%20Ricardo\%20Antunes\%20texto.pdf Acessado em 12 mai. 2018.

BOSCO, Carlos Alberto. Trabalho informal: realidade ou relação de emprego fraudulenta? Curitiba: Juruá, 2003.

CASTEL, Robert. A metamorfose da questão social. Petrópolis: Vozes, 1998.

CATHARINO, José Martins. Compêndio de Direito do Trabalho. 2.ed. São Paulo: Saraiva, 1981. 2 vol.

CHENAIS, F. A mundialização de capital. Trad. Silvana Finzi Foá. São Paulo: Xamã, 1996.

CORRÊA, Maíra Baumgarten.Tecnologia. In: CATTANI, Antonio David. (Org.) Trabalho e tecnologia: dicionário crítico. 2.ed. Petrópolis: Vozes; Porto Alegre: Editora da Universidade, 1999. p. 251-257.

DELGADO, Maurício Godinho. Curso de Direito do Trabalho. 15ª ed. São Paulo: LTr, 2016.

FREITAS JÚNIOR, Antônio Rodrigues. Direito do Trabalho na era do desemprego: instrumentos jurídicos em políticas públicas de fomento à ocupação. São Paulo: LTr, 1999.

HARVEY, David. Condição pós-moderna: uma pesquisa sobre as origens da mudança cultural. Trad. Adail Ubirajara Sobral e Maria Stela Gonçalves, 10.ed. São Paulo: Loyola, 2001. 
KUMAR, Krishan. Da sociedade pós-industrial à pós-moderna: novas teorias sobre o mundo contemporâneo. Trad. Ruy Jungmann. Rio de Janeiro: Jorge Zahar, 1997.

MANNRICH, Nelson. A modernização do contrato de trabalho. São Paulo: LTr, 1998.

MARTINS, Sérgio Pinto. Flexibilização das condições de trabalho. São Paulo: Atlas, 2000.

MORAES FILHO, Evaristo. Introdução do Direito do Trabalho. Rio de Janeiro: Forense, 1956, vol.I , Evaristo. Temas atuais de direito do trabalho e previdência. São Paulo: LTr 1976.

PEDREIRA, Pinho. O teletrabalho. Revista LTr Legislação do Trabalho. São Paulo: LTr, ano 64, n.05, p. 583-587, maio de 2003.

PRADO, Roberto Barretto. Tratado de Direito do Trabalho. 2 ed. atual, rev e aum., São Paulo: RT, 1971, vol I

Evolução histórica do direito do trabalho no Brasil. In Curso de Direito do Trabalho, em homenagem a Mozart Victor Russomano, coord. Octavio Bueno Magano. São Paulo: Saraiva, 1985.

PROSCURSIN, Pedro. O trabalho na reestruturação produtiva: análise jurídica dos impactos no posto de trabalho. São Paulo: LTr, 2001.

ROMITA, Arion Sayão. O impacto da globalização no contrato de trabalho. In Revista do Tribunal Superior do Trabalho, Brasília, vol. 66, n. 4, Porto Alegre: Síntese, out-dez 2000, p. 84-91.

Perspectivas da Reforma Trabalhista. In Revista de Direito do Trabalho, São Paulo, Revista dos Tribunais, ano 34, jan-mar 2008, n. 129, p. 26-52 
SELLA, Adriano. Globalização neoliberal e exclusão social: alternativas...? são possíveis!. São Paulo: Paulus, 2002. Coleção Temas da atualidade.

SILVA, Diana de Lima e; PASSOS, Edésio (org.). Impactos da globalização: relações de trabalho e sindicalismo na América Latina e Europa. São Paulo: LTr, 2001.

SÜSSEKIND, Arnaldo. Direito Internacional do Trabalho. 3ª Ed. São Paulo, 2000.

TEIXEIRA, Francisco J. S.; OLIVIERA, Manfredo Araújo de (Org.) Neoliberalismo e reestruturação produtiva: as novas determinações do mundo do trabalho. São Paulo: Cortez; Fortaleza: UECE, 1998. 


\title{
NECESSIDADE DE PROTEÇÃO DA SAÚDE DOS TRABALHADORES FRENTE À PRECARIZAÇÃO DAS CONDIÇÕES DE TRABALHO
}

\author{
Daniele Matos de Oliveira \\ Universidade Católica do Salvador \\ Sabrina Vianna Vilas Boas \\ Universidade Católica do Salvador
}

\begin{abstract}
Resumo
Com o crescimento do número de acidentes de trabalho após a Revolução Industrial, foi necessária a criação de regras que garantissem a segurança, higiene e saúde dos trabalhadores no ambiente de trabalho. Inúmeras normas foram criadas e foi dado amparo constitucional ao direito dos trabalhadores a segurança, higiene e saúde no trabalho. Porém, apenas a vigência de normas e o fato de estarem os empregadores obrigados a assegurarem esse direito não é o suficiente. É necessário que haja nornas específicas de proteção, assim como conscientização da indispensabilidade da aplicação das normas preventivas, e a adoção de uma atitude de cooperação entre entidade patronal e trabalhadores, ambos beneficiários da aplicação de normas preventivas.
\end{abstract}

Palavras-chave: Saúde, Higiene, Proteção, Trabalhadores, Normas

\begin{abstract}
Resumen/Résumé
With the increase in the number of industrial accidents after the Industrial Revolution, it was necessary to create rules that guarantee the safety, hygiene and health of workers in the workplace. Numerous standards were created and constitutional protection was given to workers' right to safety, hygiene and health at work. However, only the enforcement of standards and the fact that employers are obliged to ensure this right is not enough. It is necessary that there be specific nodes of protection, as well as awareness of the indispensability of the application of the preventive norms, and the adoption of an attitude of cooperation between employer and workers, both beneficiaries of the application of preventive norms.
\end{abstract}

Keywords/Palabras-claves/Mots-clés: Health, Hygiene, Protection, Workers, Standards. 


\section{Introdução}

A Constituição Brasileira de 1988 apresenta nítida evolução no que tange aos direitos dos trabalhadores, pois o homem volta a ser protagonista da proteção do Estado através da previsão de direitos e garantias fundamentais. É inquestionável a preocupação do constituinte com a proteção máxima destes direitos através da limitação de alterações no texto da constituição e com os valores sociais do trabalho, a igualdade, a dignidade da pessoa humana e seus reflexos nas relações trabalhistas, permitindo uma notável melhora entre o poder diretivo do empregador no tocante à privacidade do empregado, como se pode observar no posicionamento de Magalhães (2009).

Para Magalhães (2009) o texto de 1988, traz uma ordem econômica que tem como princípios a livre iniciativa, a livre concorrência, a propriedade privada, princípios de origem liberal que ao lado de princípios de origem socialista, como a função social da propriedade, o pleno emprego, a dignidade do trabalho humano, somam-se a direitos de terceira geração como o direito do consumidor e o meio ambiente, para apontar para uma ordem econômica que embora avançada, pois incorpora o que há de mais atual em termos de direitos fundamentais, pode no máximo ser interpretada como uma ordem econômica neoliberal em sentido amplo, com um modelo de Estado Social não clientelista, dentro de um modelo intervencionista estatal com a finalidade de promover a diminuição das desigualdades sociais e regionais dentro de um capitalismo social.

Dessa forma, a norma suprema instrumentaliza o ordenamento jurídico brasileiro buscando contemplar os direitos e deveres destes personagens com justiça e dignidade. A Lei Maior garante a todos os brasileiros e aos estrangeiros residentes no País a inviolabilidade do direito à vida, à liberdade, à igualdade, à segurança e à propriedade (BRASIL, 1988).

Lamentavelmente, parece que o neoliberalismo vem assumindo maior força nesse embate. Na ótica do neoliberalismo não se admite o conceito de direitos sociais; a condição de mercadoria da força de trabalho é reforçada, assim como a mercantilização dos bens sociais. Sem dúvida nenhuma, os anos 90 herdaram da década de 80 , um aumento da dívida social da nação. O Estado tem cada vez menos respondido às demandas, "seja pela diminuição de sua capacidade de gastos seja pela ausência de um novo bloco de poder capaz de dar governabilidade na medida em que viabilize uma nova estratégia de desenvolvimento com democracia para o Brasil"(FIORI; KORNIS, 1994).

Os valores sociais do trabalho tem natureza de direito social fundamental, ou seja, a necessidade do trabalho como fonte de subsistência do empregado. Já a finalidade da 
valorização do trabalho humano é garantir a todos os trabalhadores a existência digna de acordo com os preceitos da justiça social, quer dizer, a ordem econômica, mesmo sendo baseada no lucro, deve garantir a dignidade e a integridade do trabalhador. O Estado deve ser o maior representante da coletividade no que tange aos direitos sociais, uma vez que o Artigo 193 da Constituição Federal diz que a ordem social tem como base ao primado do trabalho e como objetivo o bem estar e as justiças sociais.

A nova realidade da segurança, higiene e saúde no trabalho tem como pilares a prevenção e a colaboração. Apesar de estar a maioria dos deveres submetidos aos empregadores, também os trabalhadores e seus representantes devem atentar para o cumprimento das normas de prevenção.

Para que se consiga diminuir o número de acidentes de trabalho e doenças profissionais, ainda muito elevados ${ }^{1}$, é necessário que trabalhador e entidade patronal despertem em si o sentimento de colaboração mútua, de co-ajuda devendo as regras preventivas ser respeitadas e cumpridas por ambas as partes.

A garantia do direito do trabalhador ${ }^{2}$ à segurança, higiene e saúde no trabalho não é para entidade patronal apenas um encargo não-lucrativo, e sim um meio para possibilitar o aumento de produção e da qualidade do produto desenvolvido. Trabalhadores mais satisfeitos tendem a trabalhar mais e melhor, o que significa uma vantagem inenarrável para o empregador.

Em razão disso, primeiramente irá se tratar de como as normas pátrias regulamentam as regras acerca de proteção da saúde dos trabalhadores no local de trabalho, e se essas normas são ou não suficientes para garantir o direito constitucional à saúde.

Num segundo momento, far-se-á uma análise sobre a precarização das condições de trabalho, o que engloba, inevitavelmente, a necessidade de atenção às condições de trabalho dos obreiros.

\footnotetext{
${ }^{1}$ Segundo dados fornecidos pela OIT, morrem diariamente 6000 trabalhadores em decorrência de acidentes e doenças relacionadas com o trabalho, número que parece vir aumentando.

Aduz ainda a OIT, que por ano ocorrem 270 milhões de acidentes não mortais (o que gera mínimo de 3 dias a menos de trabalho) e 160 milhões de casos novos de doenças profissionais. O total desses acidentes e doenças equivale a 4\% do PIB global, ou vinte vezes o montante global destinado à ajuda para o desenvolvimento.

Para melhorar essa situação, foi declarado que será celebrado em 28/04/2008 o dia mundial de Segurança e Saúde no Trabalho, com o objetivo de tentar convencer todos os que estão ligados a atividades laborais das vantagens de uma atitude preventiva (OIT, 2007).

${ }^{2}$ Para maiores detalhes sobre as características essenciais do direito à segurança, higiene e saúde no trabalho (HERNÁNDEZ, 2006).
} 


\section{2. (In)eficácia das normas para proteção à saúde dos trabalhadores}

A justiça social prevista nos artigos 170 e 193 da Constituição Federal de 1988 têm como objetivo estabelecer a harmonia entre a ordem econômica e o valor social do trabalho, já que o direito do trabalho é o instrumento para a obtenção desta justiça social. O parágrafo $2^{\circ}$ do artigo $5^{\circ}$ estabelece: "Os direitos e garantias expressos nesta Constituição não excluem outros decorrentes do regime e dos princípios por ela adotados, ou dos tratados internacionais em que a República Federativa do Brasil seja parte”. Este comando amplia o dever de obediência a outros direitos e garantias individuais implícitos.

O empregado, ainda que sujeito ao poder diretivo, atributo indeclinável da empresa, e mesmo estando vinculado ao dever de obediência às ordens que originam do contrato de trabalho, deve ser tratado com respeito e educação e dentro dos parâmetros da lei, eis que esse poder não é absoluto e nem ilimitado. Portanto, a incidência dos direitos fundamentais no âmbito do contrato de trabalho se assenta na necessidade de assegurar o respeito à dignidade do trabalhador e estabelecer limites ao exercício do poder diretivo do empregador, para tornar a relação de emprego mais justa e equilibrada. (NASCIMENTO, 2008)

O princípio da igualdade ou isonomia, disposto no artigo $5^{\circ}$ da Constituição Federal de 1988, que também não é absoluto, retrata a necessidade de tratar igualmente os iguais e desigualmente os desiguais na medida das suas desigualdades. O trabalhador recebe tratamento diferenciado por ser a parte hipossuficiente da relação trabalhista.

Sendo assim, no Brasil, as transformações do Estado foram percebidas com a Constituição Federal de 1988 após a crise do Bem-Estar Social e a implementação de políticas de descentralização e de cooperação com as ONGs - organizações não governamentais (SANTOS, J., 2011).

No início da década de 90, ocorreu a integração do Brasil à ordem econômica mundial, sob o imperativo do Neoliberalismo. Vale ressaltar que o Brasil não teve a experiência anterior do "Welfare State". Para Carvalho (1996), a realidade foi muito diferente, pois o Brasil havia passado por um processo de escravidão em que se negava a cidadania, para depois o povo ser forçado a tomar conhecimento das decisões políticas do Estado num movimento de "cima para baixo", não havendo redistribuição de resultados com a classe trabalhadora.

Os direitos sociais, só começaram a ser difundidos com a Constituição de 1988 e logo após, com a influência do Neoliberalismo, as conquistas foram aos poucos sendo esvaziadas. $\mathrm{O}$ que ocorreu de fato foi uma contra-reforma do Estado brasileiro com a criação de obstáculos e redirecionamento das conquistas da Constituição (BEHRING; BOSHETTI, 2006). Delgado 
(2013) dispõe que os mecanismos autoritários preservados pela Constituição de 1988 atuam frontalmente sobre a estrutura e dinâmica sindicais, inviabilizando, de modo ostensivo e rígido, a construção de um padrão democrático de gestão social e trabalhista no Brasil.

Marx (1974), no prefácio à "Contribuição à Crítica da Economia Política" bem explicita a natureza contraditória das relações quando afirma que é necessário explicar a consciência pelas contradições da vida material e pelo conflito entre as forças produtivas sociais e as relações de produção. Esse conflito decorre do processo de trabalho, em que o trabalhador trabalha sob o controle do capitalista, dono do seu trabalho, enquanto o produto também é propriedade do capitalista e não do produtor imediato que é o trabalhador, causando toda uma desigualdade (MARX, 2004).

Houve, no entanto, um esforço da classe dominante em redimensionar seu espaço de atuação através do desaparelhamento do Estado (SITCOVSKY, 2010). Como visto acima, no Brasil também ocorreu uma flexibilização que foi facilitada pela mudança de correlação de forças entre capital e trabalho expressa na precarização dos postos de trabalho e flexibilização dos vínculos empregatícios. Isso tudo ocorreu através do processo de terceirização e desregulamentação das relações de trabalho (BORGES, 2007), o que causou prejuízos imensuráveis à classe trabalhadora.

O reconhecimento dos direitos dos trabalhadores conquistados nos últimos anos, ainda oferece inúmeras possibilidades, pois cada mudança na etapa de evolução da sociedade moderna leva a novas conquistas de direitos.

Não há, além do texto constitucional, nenhuma norma regulamentadora capaz de proteger eficazmente a saúde dos trabalhadores, sendo a própria Consolidação das Leis Trabalhistas (CLT) extremamente vaga no tocante aos mecanismos preventivos, que devem ser adotados, a fim de proteger a saúde dos obreiros. O Ministério do Trabalho e Emprego criou duas Normas Regulamentadoras, a NR 15 e a NR 32, a fim de regulamentar o desenvolvimento de atividades laborais em ambientes insalubres, no entanto, nenhuma delas consegue englobar todos os tipos de relações de emprego existentes, fazendo com que uma série de trabalhadores brasileiros fiquem à mercê da regulamentação estabelecida através das normas coletivas.

As normas coletivas são contratos de natureza privada, que podem ser celebradas entre entidades sindicais patronais e profissionais. Na maioria das vezes são essas normas as únicas a preverem mecanismos específicos para proteção da saúde dos trabalhadores de determinada categoria. Embora a existência dessas normas seja melhor do que não haver nada, muitas vezes não há mecanismos protetivos adequados para proteção da saúde dos trabalhadores, pois a participação patronal na negociação coletiva faz com que haja concessões por parte da entidade 
sindical profissional, o que inviabiliza uma proteção adequada.

Não existe negociação coletiva sem a participação dos empregadores, portanto, não existem normas coletivas que não sejam flexibilizadas de acordo com a vontade dos mesmos. Dessa forma, a regulamentação acerca de mecanismos específicos, como equipamentos de proteção individual, capazes de preservar a saúde dos obreiros, terá sempre a participação do empresariado, já que as normas coletivas são celebradas em âmbito privado.

Apesar das dificuldades, o rigor das políticas públicas com relação aos deveres do empregador ${ }^{3}$ sobre este tema, vem aumentando com o tempo, o que demonstra uma evolução em favor dos trabalhadores, o que acaba por beneficiar também os empregadores, uma vez que a adoção de medidas preventivas diminui o número de acidentes de trabalho e doenças profissionais, e, consequentemente, as despesas que os empregadores poderiam vir a ter em decorrência de sinistros ${ }^{4}$.

\footnotetext{
${ }^{3}$ A LPRL (Lei de Prevenção dos Riscos Laborais Espanhola) preocupou-se também em enumerar as obrigações dos fabricantes e importadores de produtos utilizados para garantir a segurança, higiene e saúde no trabalho. Neste sentido:

"El art. 41 de la LPRL asigna a los fabricantes, importadores y suministradores una serie de obligaciones legales relativas a la seguridad de los trabajadores. En efecto, quedan obligados a: a) impedir que la maquinaria, equipos, productos y útiles de trabajo no constituyan una fuente de peligro para el trabajador, siempre que sean instalados y utilizados en las condiciones, forma y para los fines recomendados por ellos; b) suministrar información que permita la segura utilización de aquellos medios y productos por parte del trabajador; c) asegurar la efectividad de los elementos para la protección de los trabajadores suministrados, así como la información asociada a su uso; d) proporcionar a los empresarios, y éstos recabar de aquéllos, la información necesaria para que la utilización y manipulación de la maquinaria, equipos, productos, materias primas y útiles de trabajo se produzca sin riesgos para la seguridad y la salud de los trabajadores, así como para que los empresarios puedan cumplir con sus obligaciones de información respecto de los trabajadores.

Estas obligaciones alcanzan también al supuesto en que los trabajadores de la empresa contratista o subcontratista no presten servicios en los centros de trabajo de la empresa principal, siempre que tales trabajadores deban operar con maquinaria, equipos, productos, matérias primas o útiles proporcionados por la empresa principal (art. 24.4 de La LPRL)." (SERRANO-PIEDECASAS, 2002).

Ainda sobre a obrigação de prevenção de outros sujeitos, cite-se:

"I soggetti responsabili, la nozione di datore di lavaro e $\mathbf{i}$ problemi della delega dopo le modifiche del decreto correttivo della legge n. 626/94. -È del tutto ovvio e naturale che il principale destinatario degli obblighi prevenzionali sia il datore di lavoro, gravando su di lui il primario dovere di garantire la salute e la sicurezza dei propri dipendenti ed, in genere, di tutti coloro ehe vengono utilizzati o si trovano ad operare nell'ambito della sua organizzazione produttiva.

Ma già, fin dall' emanazione dei d.P.R. del 1955 e del 1956, la legge, muovendo dal giusto presupposto che la sicurezza è un obiettivo raggiungibile solo attraverso gli sforzi congiuntt di piu soggetti, avcva ampliato la categoria di quelli responsabili, individuandone degli altri, innanzitutto fra $\mathbf{i}$ più stretti collaboratori deI datore di lavoro, quali i dirigenti e i preposti ed estendendola anche fuori dall'azienda, fino a comprendere persone estranee ai rapporto di lavoro, come i costruttori, i commercianti, i noleggiatori e gli installatori di macchine, di impianti e di attrezzature da lavoro." (CULOTTA, 1996).

${ }^{4}$ Neste sentido: "Essa sottintende infatti Ia convinzione che la sicurezza del lavoro è un problema in relazione al quale gli interessi di datori e prestatori di lavoro sono tutt'altro che divergenti; e che pertanto entrambe le parti devono muoversi parallelamente, se non congiuntamente, nella realizzazione di quello che deve considerarsi un obiettivo comune. L'impostazione può sembrare eccessivamente "illuministica", ma ha invece concreti elementi a sostegno, primo fra i quali gli alti costi che le patologie professionali costituiscono per le aziende; costi che un'efficace opera di prevenzione può di certo ridurre." (NATULLO, 1993).

Ainda sobre os benefícios que uma atitude preventiva proporciona aos empregadores, podemos falar em "economia da prevenção", a qual ajuda o empregador a obter um produto melhor, pois ao desfrutar de qualidade
} 


\section{Precarização das condições de trabalho}

O Direito do Trabalho exerce a função social de defender os direitos do empregado, que ocupa a posição de principal destinatário, em detrimento do poder econômico do empregador. A Consolidação das Leis Trabalhistas, conhecida pela sigla CLT, além de outras leis específicas utilizadas eventualmente, é a legislação utilizada pelo Estado para a prestação jurisdicional rápida e eficiente através de normas que impõem ao empregador o cumprimento dos direitos trabalhistas devidos ao empregado em virtude de violações ocorridas durante o contrato de trabalho.

Esse ramo do Direito corresponde ao conjunto de princípios e normas, legais e extralegais, que regem tanto as relações jurídicas individuais e coletivas, oriundas do contrato de trabalho subordinado e, sob certos aspectos, da relação de trabalho profissional autônomo, como diversas questões conexas de índole social, pertinentes ao bem-estar do trabalhador (SUSSEKIND, 2004).

Um dos principais princípios do Direito do Trabalho é o da proteção do trabalhador, do qual emanam múltiplos princípios derivados ou de concretização, apontados pela doutrina como valores eminentes do Direito do Trabalho, bem como outras tantas representações legais abrangentes - uns e outros concretizam aquele princípio e prosseguem o seu objetivo de tutela da pessoa e do patrimônio do trabalhador perante o vínculo laboral.

O princípio da proteção do trabalhador inspira, por si só e sem necessidade de princípios de concretização intermédios, alguns dos aspectos do regime do contrato de trabalho que mais se desviam de regras e de princípios gerais do direito comum, como as restrições da liberdade negocial das partes pelo predomínio das normas legais imperativas, ou o reforço das exigências de forma no contrato de trabalho quando esteja em causa o estabelecimento de regimes jurídicos que enfraqueçam a posição do trabalhador, ou ainda o regime aplicável ao contrato de trabalho inválido mas executado (RAMALHO, 2005).

no trabalho, os trabalhadores exercem suas atividades de forma mais satisfatória. Para maiores detalhes acerca da "economia da prevenção", cfr. AGUDO DÍAZ, Javier, CABRERA ÁLVAREZ, Luis, MOLINERO, Serafín, RUIZ CATALÁN, Carlos, RUIZ RODRÍGUEZ, Ignacio, TOROLLO GONZÁLEZ, Francisco Javier, ZURITA BLANCAS, Jesús. Curso de Prevención de Riesgos Laborales: España en el Marco de la Unión Europea. Dykinson, Madrid, 2000.

Sobre as vantagens de uma atitude preventiva, cfr. também: GRILLO, Carlo Maria. Sicurezza sul lavoro e strutture sanitarie: responsabilità penali. La giustizia penale, Roma, s.7, a.103, n.10 (Ottobre1998), Parte II, pp. 608. 
Para a configuração do vínculo trabalhista dos trabalhadores urbanos e rurais a CLT, nos artigos $2^{\circ}$ e $3^{\circ}$ determina como necessários, ao mesmo tempo, os cinco requisitos fáticos e jurídicos, quais sejam: pessoalidade, não-eventualidade, onerosidade, alteridade e subordinação.

A pessoalidade diz respeito à impossibilidade do empregado ser substituído na prestação do serviço. A não-eventualidade ou habitualidade está ligada ao trabalho contínuo de forma sucessiva no decorrer do vínculo empregatício, onerosidade diz respeito à contraprestação pecuniária pela prestação do serviço, a alteridade é a responsabilidade dos riscos tipicamente empresariais ficarem a cargo do empregador, e por fim, a mais importante requisito que é a subordinação.

Para a definição do contrato de trabalho é importante saber que ele tem como sujeitos o empregador e o empregado, além disso, é um acordo que depende exclusivamente da vontade dos contratantes produzindo efeitos jurídicos, as partes deverão saber os direitos e deveres pactuados como salário e atividades laborais exigidas, o ordenamento jurídico não exige forma especial para sua celebração. Ele diferencia dos contratos utilizados no direito privado em virtude da especificidade do estado de subordinação e poderes hierárquicos.

O empregador tem livre arbítrio na contratação dos empregados para a obtenção dos seus objetivos empresariais, salvo raras exceções. O ordenamento jurídico do trabalho permite que a contratação ocorra de maneira tácita quando a ausência de qualquer formalidade revela a intenção ou expressa que pode ser escrita e até verbal. Cabe salientar que parte considerável das normas do direito do trabalho é de ordem pública, ou seja, a sua aplicação no contrato de trabalho, seja por prazo determinado ou por prazo indeterminado, não depende da vontade das partes.

Considera-se empregador a empresa, individual ou coletiva, que, assumindo os riscos da atividade econômica, admite, assalaria e dirige a prestação pessoal de serviço, e empregado toda pessoa física que prestar serviços de natureza não eventual a empregador, sob a dependência deste e mediante salário.

A subordinação, disposta nos artigos $2^{\circ}$ e $3^{\circ}$ da CLT, através dos conceitos de empregador e empregado, é o elemento de maior relevância na identificação do vínculo empregatício e também do poder diretivo do empregador, por simbolizar os dois lados da mesma moeda. Além disso, através dela faz-se a diferenciação das outras modalidades de contrato. Ao empregado cabe o dever de dependência, ou seja, obediência, e ao empregador o poder de comando. O conceito de subordinação é indeterminado devido às hipóteses de abrangência, cabendo aos doutrinadores e à jurisprudência o esgotamento do tema. Não há nada 
mais pacífico e controvertido, em Direito do Trabalho, como a subordinação. Pacífico como linha divisória, controvertido como dado conceitual. (VILHENA, 2005)

É através do contrato de trabalho que se estabelecem, ainda que de maneira indeterminada, através de ato volitivo, o dever de obediência e o poder de ordenar. Contudo, a subordinação e o poder diretivo encontram-se intrinsecamente conectados através de direitos e obrigações de empregador e empregado na relação de emprego.

$\mathrm{Na}$ execução do trabalho prestado a uma empresa, o trabalhador está sujeito ao poder disciplinar do empregador, vale dizer, acha-se obrigado à observância das regras disciplinares vigentes na empresa. O poder disciplinar tem seus limites. A dignidade da pessoa humana deve ser preservada a todo o custo. O interesse coletivo há de ser considerado, mas não sem ajustarse aos direitos individuais envolvidos. O melhor regime disciplinar é aquele que procura remover as causas das infrações, e não o que simplesmente se limita a punir as faltas. $\mathrm{Na}$ verdade, o princípio de igualdade não exclui a posição jurídica de subordinação entre particulares nem o exercício do poder disciplina pelo empregador faz supor o reconhecimento de supremacia sobre o empregado. (ROMITA, 1983)

A concepção típica de subordinação está apresentando transformações em virtude dos avanços tecnológicos que estão surgindo na vida moderna e também nos meios de produção. Essas mudanças estão provocando alterações nos limites e na forma de identificação deste poder. No decorrer do estudo serão apresentados oportunamente os referidos avanços e seus desdobramentos. Para Sergio Pinto Martins existem 04 teorias que conceituam o poder disciplinar.

As quatro teorias que fundamentam o poder disciplinar. Confira-se: a) teoria negativista: esclarece que o empregador não pode punir o empregado, pois o direito de punir é pertencente ao estado, que detém o direito privativo inerente ao ius puniendi; b) teoria civilista ou contratualista: estabelece que o poder disciplinar decorre do contrato de trabalho. As sanções disciplinares estariam equiparadas às sanções civis, como se fossem cláusulas penais. Entretanto, as sanções civis dizem respeito a indenizar uma pessoa pelo prejuízo causado por outra, ou seja, restabelecer a situação patrimonial da pessoa atingida; c) teoria penalista: informa que as penas têm o mesmo objetivo: assegurar a ordem na sociedade. A diferença seria que a pena prevista no Código Penal visa assegurar a repressão em relação a todo o indivíduo que cometer um crime, enquanto as pena disciplinar está adstrita apenas aos empregados e no âmbito da empresa; d) teoria administrativa: entende que o poder disciplinar decorre do poder de direção, de o empregador administrar a empresa de maneira que ela venha a funcionar adequadamente. Derivaria a teoria administrativa da ideia de que a empresa é uma instituição, 
equiparando-se ao ente público, podendo, assim, o empregador impor sanções disciplinares ao empregado, até mesmo porque é o dono do empreendimento, devendo manter a ordem e a disciplina no âmbito da empresa. (MARTINS, 2006).

Os poderes hierárquicos são originários do direito de propriedade e da livre iniciativa, garantidos na constituição brasileira. Tanto a doutrina quanto a jurisprudência reconhecem o poder disciplinar do empregador. A gênese do poder disciplinar é contratual, nunca associada ao poder de punir do Estado. Ele é facultado ao empregador em virtude do ônus da responsabilidade pelos riscos da atividade empresarial, por proporcionar o trabalho, pelo pagamento do salário,etc. Para Mauricio Godinho Delgado "São poderes hierárquicos do empregador: o conjunto de prerrogativas com respeito à direção, regulamentação, fiscalização e disciplinamento da economia interna da empresa e correspondente prestação de serviços" (MARTINS, 2006).

O poder diretivo é o núcleo da hierarquia e disciplina do vínculo empregatício através do qual todos os outros poderes do empregador derivam. O poder disciplinar é a faculdade que o empregador tem para aplicação de penalidades pela violação das normas da empresa e normas trabalhistas conforme o artigo 482 da CLT. O poder de regulamentar se verifica através do estabelecimento de diretrizes e limites da atuação do empregado. Através da fiscalização, o empregador exerce o controle das atividades desempenhadas pelo o empregado. Na prática, esse poder, muitas vezes, tem violado os direitos constitucionalmente garantidos aos empregados se tornando objeto frequente de causas na Justiça do Trabalho. A organização é o gerenciamento através de determinações de como as tarefas devem ser executadas. Ela aparece na rotina do trabalho das mais variadas formas.

O empregado, ainda que sujeito ao poder diretivo, atributo indeclinável da empresa, e mesmo estando vinculado ao dever de obediência às ordens que originam do contrato de trabalho, deve ser tratado com respeito e educação e dentro dos parâmetros da lei, eis que esse poder não é absoluto e nem ilimitado. Portanto, a incidência dos direitos fundamentais no âmbito do contrato de trabalho se assenta na necessidade de assegurar o respeito à dignidade do trabalhador e estabelecer limites ao exercício do poder diretivo do empregador, para tornar a relação de emprego mais justa e equilibrada (NASCIMENTO, 2008).

Todavia, estes poderes não são absolutos, o uso discricionário destas prerrogativas deve ser usado de forma restrita, evitando assim a violação de garantias constitucionais vigentes. A ausência de normas específicas para tutelar esse poder coloca o empregado em posição vulnerável em detrimento da usurpação de poderes pelo empregador. Os princípios da dignidade da pessoa humana, da proporcionalidade, razoabilidade, isonomia e in dubio pro- 
operário, funcionam como reguladores e limitadores desta autoridade. A intervenção Estatal visa resguardar a proteção do empregado pelas lesões sofridas através da responsabilização pecuniária, garantindo sempre ao empregado, em juízo, a presunção de inocência.

Embora, haja nítidas regras para celebração e execução do contrato de trabalho, no Brasil a maioria dessas normas acabam sendo descumpridas, o que provoca uma grande precarização das condições de trabalho. Além do descumprimento das normas que já existem, há também o problema da não existência de normas específicas de segurança e proteção à saúde para determinadas categorias.

Não há, por exemplo, normas públicas de proteção à saúde dos trabalhadores expostos ao urânio no Brasil, embora se tenha em território nacional minas ativas de urânio desde 1992. Muito embora o urânio seja considerado um agente insalubre, em razão da radiação por ele liberada, não existem regras legais ou emanadas do Poder Executivo capazes de protegerem a vida dos trabalhadores expostos ao urânio e dos seus descendentes.

Tem-se, assim, uma grave precarização das condições de trabalho dos trabalhadores, que se veem sujeitos a uma mera normatização privada, através de normas coletivas, instrumento que nem sempre é celebrado levando-se em consideração apenas o bem-estar dos trabalhadores. O que se nota na maioria das vezes, que por se tratar de um acordo privado, a convenção coletiva de trabalho faz ponderações entre o que é bom para os trabalhadores e o que é vantajoso para os empregadores.

Toda essa desigualdade e contradição decorrente da hegemonia do mercado atingiu um alto nível de naturalização social, em que a difusão social da produção contribuiu para desocultar novas formas de opressão (SANTOS, 2001) como, por exemplo, a liberdade sindical, a qual vem sendo utilizada como justificativa para a não criação de políticas públicas eficientes, havendo de forma desenfreada um equivocado incentivo à flexibilização dos vínculos empregatícios, já que se utiliza as normas coletivas celebradas entre entidades sindicais como instrumento flexibilizador dos direitos dos trabalhadores.

\section{Considerações finais}

Apesar de haver normas básicas de proteção à saúde dos trabalhadores, não há diplomas específicos capazes de proteger os obreiros em todos os tipos de relação de emprego existentes no Brasil.

Deve-se levar em consideração que as medidas de proteção à saúde de um operador de computador, como um caixa de um banco, não podem ser as mesmas utilizadas para proteção 
dos trabalhadores na esfera da construção civil. Nota-se que cada categoria tem suas necessidades próprias e precisa de regras capazes de assegurar a proteção à saúde e à vida dos trabalhadores.

A inexistência de políticas públicas específicas e capazes de proteger os diferentes tipos de trabalhadores existentes no mercado de trabalho, deixa a encargo da negociação coletiva o dever de celebrar normas, que tenham a finalidade de proteção dos obreiros.

Ocorre que, as normas coletivas celebradas através de negociação coletiva são normas de caráter privado e possuem a participação igualitária tanto dos trabalhadores quanto dos empregadores. Permite-se, assim, uma negociação acerca de como se deve proteger a vida dos trabalhadores, não podendo esquecer que o empresariado sempre irá preferir aquilo que lhe for menos oneroso.

Como a vida humana não tem preço pecuniário e os direitos dos trabalhadores são irrenunciáveis e invioláveis, permitir que normas acerca de proteção à saúde sejam celebradas em âmbito privado faz com que aumente o índice de precarização das condições de trabalho.

Para dar maior credibilidade ao direito à segurança, higiene e saúde no trabalho a maioria dos países o revestiu de caráter constitucional, para que outros direitos constitucionais fossem igualmente assegurados. Dessa forma, os direitos à vida, à saúde e à integridade física são resguardados de maneira mais abrangente e segura.

A análise não só do sistema jurídico português, o qual é objeto principal do nosso estudo, como também dos sistemas jurídicos comunitário e internacional, fez-nos observar, que como na maioria dos temas, o Direito do Trabalho é bastante protecionista (em prol do trabalhador).

Apesar de o custo para a adoção eficaz das normas de segurança, higiene e saúde ser bastante elevado, o empregador pode acabar tendo mais gastos, caso não preze pelo cumprimento das regras de prevenção de riscos. Arcar com as consequências de acidentes ou doenças laborais é uma atitude muito menos inteligente por parte do empregador, visto que o valor de uma única indenização decorrente de acidente de trabalho, é muitas vezes superior ao valor que a entidade patronal gastaria para implementar de forma adequada as normas de segurança.

Ademais, os trabalhadores que desempenham suas atividades em ambiente agradável, salubre e seguro são muito mais satisfeitos com a função exercida, o que faz aumentar a qualidade do produto final, resultado que, obviamente, é muito vantajoso para o empregador.

Apenas através da aplicação das normas preventivas é possível garantir um ambiente de trabalho ideal, que não ofereça riscos para a saúde e integridade física dos trabalhadores, e 
que proporcione à entidade patronal a obtenção de um produto final de maior qualidade e satisfação ao perceber que seus trabalhadores sentem prazer em desempenhar suas atividades.

\section{Referências bibliográficas}

AGUDO DÍAZ, Javier, CABRERA ÁLVAREZ, Luis, MOLINERO, Serafín, RUIZ CATALÁN, Carlos, RUIZ RODRÍGUEZ, Ignacio, TOROLLO GONZÁLEZ, Francisco Javier, ZURITA BLANCAS, Jesús. Curso de Prevención de Riesgos Laborales: España en el Marco de la Unión Europea. Dykinson, Madrid, 2000.

BEHRING, Elaine Rosseti e BOSCHETTI, Ivanete. Política social no Brasil contemporâneo: entre a inovação e o conservadorismo. In: Política Social: fundamentos e história. São Paulo, Cortez, 2006, p. 147-191.

BORGES, Angela. Mercado de Trabalho: Mais de uma década de precarização. In G. Druck \& T. Franco (Orgs.), A perda da razão social do trabalho: terceirização e precarização. São Paulo: Boitempo,2007, p. 81-94.

BRASIL. Constituição. Brasília: Senado Federal, 1988. . Decreto-Lei 5452, de $1^{\circ}$ de Maio de 1943. Aprova a Consolidação das Leis do

Trabalho. Disponível em: < http://www.planalto.gov.br/ccivil_03/decreto-lei/del5452.htm>. Acesso em: 1 mar. 2015.

. Ministério do Trabalho e Emprego. NR 15, Portaria MTB nº 3214, de 08 de junho de 1978. Dispõe sobre atividades e operações insalubres. Disponível em: $<$ http://portal.mte.gov.br/legislacao/norma-regulamentadora-n-15-1.htm>. Acesso em: 1 mar. 2015.

. Ministério do Trabalho e Emprego. NR 32, Portaria GM n ${ }^{\circ} 485$, de 11 de novembro de 2005. Dispõe sobre segurança e saúde no trabalho em estabelecimentos de saúde. Disponível em: < http://portal.mte.gov.br/legislacao/normas-regulamentadoras-1.htm>. Acesso em: 1 mar. 2015. 
Decreto-Lei 5452, de $1^{\circ}$ de Maio de 1943. Aprova a Consolidação das Leis do

Trabalho. Disponível em: < http://www.planalto.gov.br/ccivil_03/decreto-lei/del5452.htm>. Acesso em: 1 mar. 2015.

. Lei 6453, de 17 de outubro de 1977. Dispõe sobre a responsabilidade civil por danos nucleares e a responsabilidade criminal por atos relacionados com atividades nucleares e dá outras providências. Disponível em:

$<$ http://www.planalto.gov.br/ccivil_03/leis/L6453.htm>. Acesso em: 1 mar. 2015.

. Lei 9605, de 12 de fevereiro de 1998. Dispõe sobre as sanções penais e administrativas derivadas de condutas e atividades lesivas ao meio ambiente, e dá outras providências. Disponível em: <http://www.planalto.gov.br/ccivil_03/leis/19605.htm>. Acesso em: 1 mar. 2015.

. Ministério do Trabalho e Emprego. NR 15, Portaria MTB no 3214, de 08 de junho de 1978. Dispõe sobre atividades e operações insalubres. Disponível em: $<$ http://portal.mte.gov.br/legislacao/norma-regulamentadora-n-15-1.htm>. Acesso em: 1 mar. 2015.

. Ministério do Trabalho e Emprego. NR 32, Portaria GM no 485, de 11 de novembro de 2005. Dispõe sobre segurança e saúde no trabalho em estabelecimentos de saúde. Disponível em: <http://portal.mte.gov.br/legislacao/normas-regulamentadoras-1.htm>. Acesso em: 1 mar. 2015.

CARVAlHO, José Murilo de. Cidadania: tipos e percursos. In: Política Social: fundamentos e história. São Paulo, Cortez, 2006, p. 147-191.

CULOTTA, Angelo. Il nuovo sistema sanzionatorio in materia di sicurezza ed igiene del lavoro e le responsabilità penali in caso di attività date in appalto. Rivista italiana di diritto e procedura penale, Milano, Nuova serie,a.39(Ottobre-Dicembre1996), p.949-973.

DELGADO, Maurício Godinho. Curso de Direito do Trabalho. $12^{\mathrm{a}}$ ed. São Paulo. LTR. 2013. P. 122. 
FIORI, J. L.; KORNIS, G. E. M. Além da queda: economia e política numa década enviesada. In: GUIMARÃES,R.; TAVARES,R. (org.). Saúde e sociedade no Brasil - anos 80. Rio de Janeiro, Relume do Mará, 1994. p. 1-42.

GRILLO, Carlo Maria. Sicurezza sul lavoro e strutture sanitarie : responsabilità penali. La giustizia penale, Roma, s.7a.103n.10(Ottobre1998), Parte II, pp. 602-608.

HERNÁNDEZ, María Luisa Martín. El Derecho de los Trabajadores a la Seguridad y Salud en el Trabajo. CES, Madrid, 2006, pp. 293 e ss.

MARTINS, Sérgio Pinto: Direito do Trabalho. 22a edição. São Paulo: Atlas, 2006.

MARX, Karl. Contribuição à crítica da economia política. Trad. port. São Paulo: Abril Cultural, 1974 (Os Pensadores).

. O Capital: crítica da economia política: Livro 1, Volume 1, 22 ${ }^{\mathrm{a}}$ Ed. Rio de Janeiro - Civilização Brasileira, 2004.

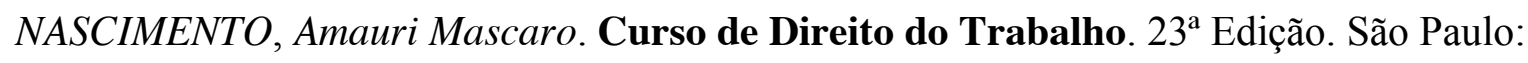
Saraiva, 2008.

NATULLO, Gaetano. Sicurezza del Lavoro e Representanze dei Lavoratori nella Prospettiva del Diritto Comunitario. Diritto della Relazioni Industriali, Milano, a. 3, n. 1, (Gennaio 1993), p 205-216.

ROMITA, Arion Sayão. O poder disciplinar do empregador. Rio de Janeiro: Biblioteca Jurídica Freitas Bastos, 1983.

SANTOS, Boaventura de Sousa. Subjectividade, cidadania e emancipação. In: Pela Mão de Alice. O social e o Político na pós-modernidade. Boaventura de Sousa Santos. P. 75-280. $7^{\text {a }}$ Ed. São Paulo: Cortez, 2001. 
SERRANO-PIEDECASAS, J. R.. La responsabilidad penal del empresario, personal técnico y de los servicios de prevención en los delitos contra la seguridad e higiene en el trabajo. Revista penal, Madrid, n.10(Julio2002), p.94-111.

SITCOVSKY. M. Particularidades da expansão da assistência social no Brasil. In: MOTA, A. E. (Org.) O mito da assistência social: ensaios sobre Estado, política e sociedade. 4. ed. São Paulo: Cortez, 2010.

SUSSEKIND, Arnaldo. Curso de Direito do Trabalho. São Paulo, Editora Renovar, 2004.

VILHENA, Paulo Emílio Ribeiro de. Relação de Emprego. São Paulo, Editora LTr, 2005. 


\title{
O CONTRATO INTERMITENTE E O TEMPO MORTO DE TRABALHO
}

\author{
Clarisse Inês de Oliveira \\ Universidade Federal Fluminense - UFF \\ Patrícia Garcia dos Santos \\ Universidade Federal do Rio de Janeiro - UFRJ \\ Instituto Brasileiro de Mercado de Capitais - IBMEC
}

\section{Resumo}

A Lei 13.467/2017 procedeu a diversas desregulamentações na legislação de ordem pública laboral, de modo que novas modalidades de contratação foram introduzidas no ordenamento jurídico trabalhista. Uma das novidades introduzidas pela "Reforma" foi o denominado contrato intermitente, que consiste na prestação de serviços, por parte do empregado, com subordinação, não contínua, ocorrendo com alternância de períodos de prestação de serviços e de inatividade. Em oposição ao argumento de geração de empregos, a modalidade intermitente apenas veio a regulamentar a jornada móvel, excluindo todo tempo morto de trabalho e a consequente remuneração daí advinda.

Palavras-chave: Contrato intermitente, jornada móvel, precarização, flexibilização, desregulamentação.

\begin{abstract}
Resumen/Résumé
Law 13467/2017 made several deregulations in the legislation of public order labor, so that new modalities of hiring were introduced in the labor legal system. One of the novelties introduced by the "Reform" was the so-called intermittent contract, which consists of the provision of services by the employee, with subordination, not continuous, occurring with alternating periods of service rendering and inactivity. As opposed to the argument for job creation, the intermittent modality only regulated the mobile journey, excluding all dead time of work and the consequent remuneration derived therefore.
\end{abstract}

Keywords/Palabras-claves/Mots-clés: Intermittent contract, mobile journey, precariousness, flexibilization, desregulation. 


\section{Introdução}

A Lei 13.467/2017, denominada “ Reforma Trabalhista" procedeu a diversas desregulamentações na legislação de ordem pública laboral, de modo que novas modalidades de contratação foram introduzidas no ordenamento jurídico trabalhista.

Uma das novidades introduzidas pela "Reforma" foi o denominado contrato intermitente, que consiste na prestação de serviços, por parte do empregado, com subordinação, não contínua, ocorrendo com alternância de períodos de prestação de serviços e de inatividade, determinados em horas, dias ou meses, podendo ser aplicado a qualquer atividade econômica ou categoria profisssional, à exceção dos aeronautas.

Havendo prestação de serviços, a remuneração correspondente será quitada após a imediata realização, com o pagamento do salário, das férias acrescidas do terço constitucional e do décimo terceiro salário cabíveis.

Instituiu a novel lei que os tempos sem trabalho no insterstício de uma tarefa e outra não serão considerados tempo a disposição do empregador.

Dessa forma, o presente artigo pretende discutir a partir do marco teórico da doutrina de Karl Marx como o Direito juridificou a prática do mercado de se remunerar apenas e tão somente o tempo efetivo de trabalho, deixando à margem de qualquer remuneração o tempo morto de trabalho.

A porosidade do tempo morto de trabalho restou definitivamente excluída da folha de pagamento empresarial com a inclusão do contrato intermitente, um antigo reclamo do capital, que almejava remunerar somente o tempo de trabalho concreto, afastando o tempo a disposição do empregador e os hiatos existentes durante a jornada de trabalho clássica de oito horas diárias.

Com o contrato de trabalho intermitente, o empregador deixou de quitar os tempos anteriormente remunerados de pausa e almoço que variavam entre quinze minutos a uma hora, a depender da carga horária diária, além dos espaços de tempo em que o trabalhador permanecia à disposição do empregador, seja aguardando ordens, seja em trânsito no percurso casatrabalho, seja para se preparar previamente para a própria jornada diária, com asseio, higiene, vestuário, etc. 
Igualmente, o tempo de preparo que antecedia o início da jornada foi igualmente excluído do cômputo da jornada, em oposição ao que previa a antiga redação dos artigos $4^{\circ} \mathrm{e}$ 58 parágrafos $1^{\circ}$ e $2^{\circ}$ da CLT ${ }^{1}$ e Súmulas $366^{2}$ e $429^{3}$ ambas do Tribunal Superior do Trabalho.

O presente artigo pretende investigar como o modelo de contrato intermitente, como proposta desregulamentadora de modalidade contratual, veio a legitimar antigo anseio do capital de excluir o tempo morto de trabalho, maximimizando a mais valia da jornada e acabando com a porosidade da jornada laboral.

Para tanto, será utilizada a revisão bibliográfica da teoria marxista para questionar se o Direito, com supedâneo na Lei 13.467 de 2017, foi utilizado como instrumento exploratório da mão de obra maximizada pela mais valia em seu grau máximo de exploração permitido normativamente.

Dessa forma, ao cotejar a exposição de motivos da nova legislação, visando a incentivar a produção de empregos, com a ideia final de afastamento da porosidade no tempo de trabalho, justifica-se a análise do texto normativo para entender se o advento do contrato de trabalho intermitente poderá gerar empregos ou se trata de uma modalidade contratual que visa a enxugar o tempo morto de trabalho e atender aos anseios do capital.

\section{O tempo de trabalho na concepção marxista e a regulação pelo Direito}

O vínculo empregatício está diretamente relacionado com a concepção de jornada ${ }^{4}$, sendo o domínio do tempo de trabalho alheio que dá ao capitalista o poder de se apropriar do

\footnotetext{
${ }^{1}$ Redação do artigo $4^{\circ}$ da CLT antes da vigência da Lei 13.467 de 2017: 'Considera-se como de serviço efetivo o período em que o empregado esteja à disposição do empregador, aguardando ou executando ordens, salvo disposição especial expressamente consignada'.

Redação do artigo 58, parágrafo $1^{\circ}$ da CLT antes da vigência da Lei 13.467 de 2017: 'Não serão descontadas nem computadas como jornada extraordinária as variações de horário no registro de ponto não excedentes de cinco minutos, observado o limite máximo de dez minutos diários.

Parágrafo $2^{\circ} \mathrm{O}$ tempo despendido pelo empregador até o local de trabalho e para o seu retorno, por qualquer meio de transporte, não será computado na jornada de trabalho, salvo quando, tratando-se de local de difícil acesso ou não servido por transporte público, o empregador fornecer a condução'.

${ }^{2}$ CARTÃO DE PONTO. REGISTRO. HORAS EXTRAS. MINUTOS QUE ANTECEDEM E SUCEDEM A JORNADA DE TRABALHO. Não serão descontadas nem computadas como jornada extraordinária as variações de horário do registro de ponto não excedentes de cinco minutos, observado o limite máximo de dez minutos diários. Se ultrapassado esse limite, será considerada como extra a totalidade do tempo que exceder a jornada normal, pois configurado tempo à disposição do empregador, não importando as atividades desenvolvidas pelo empregado ao longo do tempo residual (troca de uniforme, lanche, higiene pessoal, etc)".

3 SUM-429 TEMPO À DISPOSIÇÃO DO EMPREGADOR. ART. $4^{\circ}$ DA CLT. PERÍODO DE DESLOCAMENTO ENTRE A PORTARIA E O LOCAL DE TRABALHO.

Considera-se à disposição do empregador, na forma do art. $4^{\circ}$ da CLT, o tempo necessário ao deslocamento do trabalhador entre a portaria da empresa e o local de trabalho, desde que supere o limite de 10 (dez) minutos diários. ${ }^{4}$ Art. $4^{\circ}$ da CLT - Considera-se como de serviço efetivo o período em que o empregado esteja à disposição do empregador, aguardando ou executando ordens, salvo disposição especial expressamente consignada.
} 
lucro extraído desse trabalho, parafraseando Marx, já que "as mercadorias são apenas medidas determinadas de tempo de trabalho cristalizado" (MARX, 2011).

Porém, antes mesmo da organização do modo de produção capitalista, já há indícios de luta sobre a duração da jornada de trabalho, na Inglaterra elisabetana, quando o Estado legislou um aumento da duração de jornada de trabalho costumeira para trabalhadores que tiveram as terras expropriadas e cujo tempo livre passou a significar uma ameaça ao regime. A partir desse marco histórico, novos hábitos de trabalho foram forjados, construindo uma disciplina temporal que foi se intensificando ao longo da história com o intuito de maximização da extração de trabalho excedente do trabalhador, gênese da mais-valia.

\begin{abstract}
A batalha em torno dos minutos e segundos, do ritmo e da intensidade das escalas de trabalho, da vida de trabalho (e dos direitos de aposentadoria), da semana e do dia de trabalho (com direitos a 'tempo livre'), do ano de trabalho (e dos direitos a férias pagas), foi, e continua a ser, travada com bastante regularidade. Os trabalhadores aprenderam a reagir dentro dos limites do sentido recém-internalizado de tempo (HARVEY, 2008).
\end{abstract}

A força de trabalho, convertida em um resultado com valor de mercado, é comprada pelo valor que custa para produzi-la, utilizando como parâmetro um dispêndio de trabalho social médio na execução de determinada atividade.

O empregador paga pelo trabalho necessário, porém, não paga pelo produto da força de trabalho, mas se apropria desse resultado, que pode assumir um valor de mercado maior do que o valor determinado para o trabalho que o produziu, e quanto maior o resultado maior a diferença em forma de lucro. Nessa fórmula o fator tempo é essencial para a acentuação do lucro, seja pelo alongamento do tempo de trabalho através da ampliação da jornada e produção de trabalho excedente, seja pela máxima utilização do tempo de trabalho predeterminado através da intensificação do ritmo na execução das tarefas, sempre ocasionando mais trabalho.

Sob essa perspectiva, a definição e otimização da duração do trabalho são fundamentais para a compreensão de quanto o empregado precisa trabalhar além do necessário para produzir valor suficiente para cobrir o custo do seu próprio salário. Os Princípios da Administração Científica, de F. W. Taylor, um influente tratado que descrevia como a produtividade poderia ser aumentada através da decomposição de cada processo de trabalho em tarefas segmentadas e dissociadas segundo padrões rigorosos de estudo do tempo e do movimento é um exemplo da preocupação que se disseminou entre os capitalistas, com o desenvolvimento do processo industrial, em estabelecer um ponto ótimo para a maior extração da mais-valia. 
Para compreender o processo de exploração que se traduz na subsunção do tempo de vida do homem livre a serviço do capital, é providencial investigar a evolução histórica da divisão do trabalho que remonta ao período medieval, pois, assim como o trabalho subordinado, o trabalho excedente não é invenção do capitalismo, apesar de ser sob a égide desse novo modo de produção que o controle do tempo assume contornos extremos. O fato é que toda vez que um segmento social assume o monopólio dos meios de produção, sendo o trabalhador livre ou não, ao mesmo é atribuído trabalho além da sua necessidade destinado a produzir meios de subsistência para o proprietário desses meios. Ocorre que em uma sociedade onde predomine a produção voltada para o consumo, e não para o comércio, o trabalho excedente só se justifica em torno da satisfação das necessidades.

E os excessos não eram praticados apenas no berço da Revolução Industrial. Na metade do século XIX, na França, trabalhavam-se 12 horas nas províncias e 11 horas em Paris, com variações segundo o ramo de produção. Nas minas de Loire, os mineiros passavam 12 horas diárias no fundo e cumpriam 10 horas de trabalho efetivo. Havia jornadas de 14 e 15 horas nas fábricas de alfinetes. As tecelagens exigiam 14 ou 15 horas, se o trabalho era em domicílio, e 12 horas, na própria fábrica. Nas minas e metalurgias, o trabalho noturno generalizava-se. Nas minas de carvão de Commentry, a extração desenvolvia-se das 4 às 16 horas e, durante as 12 horas restantes realizava-se a terraplanagem das cavidades deixadas pelo carvão.

Os exemplos comprovam que o alongamento da jornada é um processo historicamente constatável que atingiu seu ápice com a Revolução Industrial, porém, está associado à degradação física e mental dos trabalhadores, com implicações não só à saúde e integridade física dos mesmos, mas com reflexo direto na queda da produtividade e no aumento dos custos decorrentes dos acidentes de trabalho. Durante o curso do processo de industrialização, em parte sensibilizados pela mobilização dos trabalhadores pela redução da jornada a limites aceitáveis, importantes setores da sociedade britânica se uniram ao movimento exigindo controles legais ao Parlamento, que, gradativamente restringiu as horas diárias de trabalho, primeiro a doze, depois a onze e, mais tarde, a dez.

Esse controle passa a centrar-se na redução do tempo de não-trabalho, que Marx identifica como "porosidade" Inicialmente através de investimentos em equipamentos modernos para aumentar a produção e o ritmo do trabalho, o empregador passa a obter maior dispêndio de energia dos seus operários. A introdução de máquinas e equipamentos eleva as exigências sobre o trabalhador em termos de aprendizado, adaptação, ritmo e velocidade, gerando um aumento da intensidade do trabalho, porém, novas tecnologias não são essenciais 
para a intensificação do trabalho. Um serviço passa a ser considerado mais intenso quando, mantidas a duração da jornada e as mesmas condições de infraestrutura produtiva, o trabalhador apresenta mais ou melhores resultados, e é mais que esforço físico, pois envolve todas as capacidades do trabalhador.

Mas indubitavelmente a maquinaria é um meio poderoso para aumentar a produtividade e diminuir o tempo de trabalho necessário à produção, tornando-se inicialmente o mecanismo mais potente para prolongar a jornada de trabalho além dos limites estabelecidos pela natureza humana. Em especial, seu uso pela indústria em construção alimenta a cobiça por mais trabalho. E ao expandir sua aplicação, aumenta naturalmente a velocidade do trabalho e, em consequência, sua intensidade. Assim, durante meio século na Inglaterra, o prolongamento da jornada de trabalho ocorre associado à sua intensificação e a aplicação de novas tecnologias. Progressivamente a intensificação vem substituindo o prolongamento, e novos métodos de gestão repensam a intensificação sem alterar o custo de realização do trabalho.

A proposta da administração científica do trabalho constitui o exemplo mais claro de um processo de elevação do grau de intensidade sem investimentos tecnológicos significativos. O ponto central das ideias de Taylor está no extermínio do 'subtrabalho'. Esse extermínio se torna possível por meios de controle mecânicos do ritmo e velocidade do trabalho, através do movimento contínuo da linha de montagem, do cronômetro, do relógio de ponto, da robotização, da fiscalização direta, das tabelas de metas, e da inserção de dispositivos automatizados de inicialização e finalização das tarefas. O taylorismo, modernizado pelo fordismo, é o método de administração do trabalho aplicado por mais de meio século, entre 1920 e 1970.

O tempo de trabalho passa a ser medido de duas maneiras: segundo sua extensão, sua duração, e segundo seu grau de condensação, sua intensidade. E ainda hoje, as tentativas de acelerar os processos de trabalho, e, portanto, de gerar mais trabalho, está no cerne do conflito entre empregado e empregador. O empregador afirma seu direito como proprietário da força de trabalho quando procura prolongar e intensificar ao máximo a jornada de trabalho. O que ele deseja, na realidade, é multiplicar o lucro através da multiplicação do trabalho. E o empregado, que pela própria natureza do trabalho, não está dissociado das atividades que executa, procura afirmar o seu direito como indivíduo quando reivindica uma limitação razoável para essa jornada, desejando ampliar seu tempo de vida livre, dando a esse conflito sobre o tempo uma conotação endêmica e universal.

O fundamento econômico da limitação da duração do trabalho consiste na tensão estabelecida entre a busca pelo ponto ótimo para a maior extração da mais-valia, e a resistência 
dos trabalhadores pela redução da mais-valia no que concerne à redução da jornada e a ampliação dos salários. Essa limitação é dada através da regulamentação da duração do trabalho, que é o tempo disponibilizado pelo empregado ao seu empregador em decorrência do contrato, através da definição da jornada diária, que consiste na quantidade de horas a serem trabalhadas por dia, normalmente limitadas por um termo inicial e final. A duração normal de trabalho, padronizada pela Constituição Federal no art. $7^{\circ}$, inciso XIII, é de 8 horas diárias e 44 horas semanais, sendo esse o limite máximo autorizado pelo Estado, salvo trabalho extraordinário suplementar, realizado em circunstâncias eventuais.

Não obstante todas as considerações apresentadas, a categoria tempo de trabalho é absolutamente central para compreender a noção de valor. $\mathrm{O}$ valor é o tempo de trabalho socialmente necessário para produzir qualquer bem ou serviço. O valor é o tempo de trabalho consumido de acordo com os padrões médios vigentes na sociedade. Valor tem a ver com tempo de trabalho e com o trabalhador. Valor é produzido pelo trabalhador gastando tempo de trabalho. E o valor do trabalho é calculado, através da lógica capitalista, utilizando critérios objetivos que fazem parte da estratégia para subtrair valor e tempo de vida do indivíduo que vende sua força de trabalho. E ao investigar o salário como parte dessa estratégia de subsunção, o que se pretende é revelar a mágica que encolhe o tempo e, mesmo assim, continua produzindo mais trabalho.

É importante ressaltar que, ao adotar como resposta ao novo cenário de reestruturação produtiva aliado ao retorno do ideal político de Estado Mínimo, um modelo de regulação focado na redução de custos e no atendimento aos interesses do capital, as alterações legais promovidas pelo Estado Brasileiro no curso das últimas décadas provocaram uma reviravolta nos pilares de sustentação do modelo clássico de contratação da força de trabalho: o trabalho assalariado com vínculo de subordinação, traduzido no clássico modelo do contrato a prazo indeterminado como regra do Direito do Trabalho brasileiro.

O relógio, principal aliado do capital no controle e garantia do máximo de extração possível da capacidade e energia do trabalhador, foi substituído por subterfúgios ainda mais eficientes, permitindo ao empregador adequar os excessos de acordo com as suas necessidades, praticamente reduzindo a zero o trabalho que não agrega valor. Técnicas de intensificação, aliadas a regulamentação do banco de horas e a permissão do trabalho aos domingos têm se mostrado mecanismos extremamente úteis na racionalização do tempo de trabalho. O que essas mudanças trazem de mais perverso é a ilusão de que a tecnologia e as novas técnicas de gestão promovem uma liberação do tempo de trabalho e uma ampliação do tempo livre. Perverso porque na realidade a jornada flexível (que não fica claramente estabelecida através de horários 
fixos) coloca o trabalhador a mercê de um empregador que pode alcançá-lo fora do espaço de trabalho, fazendo com que o tempo de trabalho invada silenciosamente o tempo de não-trabalho e que o trabalhador encare essa apropriação como parte do peso que precisa carregar para se manter em um mercado mais competitivo.

Enquanto nas modalidades de contratação com fragilização do vínculo de subordinação o papel das alterações legais foi limitado, nos temas centrais da flexibilização da remuneração e da jornada de trabalho o impacto das novas regras foi decisivo para a reconfiguração do contrato de trabalho clássico. A limitação da jornada de trabalho sempre foi objeto central de regulação pelo direito do trabalho, sendo o seu reconhecimento em regra legal uma importante conquista em detrimento à liberdade de mercado e de contratação em fixar a quantidade de horas de trabalho a que se submeteria o trabalhador. Sob essa ótica, a flexibilidade da jornada que permite sincronizar o nível de produção com a demanda de trabalho e fazer ajustes para uma administração dos horários, da modalidade das tarefas e das responsabilidades focados nos objetivos da empresa, racionalizando o tempo de trabalho, seria um retorno à liberdade de contratação, onde o tempo de vida do trabalhador fica a critério de quem o emprega.

Além dessas medidas de flexibilização temporal adotadas no Brasil, alguns países, adeptos da extensão do tempo de trabalho para ampliar a mais valia, vêm introduzindo medidas legais que na contramão das reivindicações histórica dos trabalhadores pela redução da jornada, visam prolongar os limites estipulados em lei de maneira ainda mais explícita. O governo do Japão, por exemplo, introduziu há alguns anos um projeto de lei para elevar os limites da jornada de trabalho de 9 para 10 horas, e a semana de trabalho de 48 para 52 horas. Tal regra permitirá que as empresas obriguem os empregados a trabalhar mais horas quando houver mais atividades, desde que o total de horas trabalhadas em um ano não exceda os novos limites fixados. Essa medida permite a estipulação de cotas estritas aos trabalhadores que significam longas horas de trabalho e trabalho não pago, que são identificados como 'trabalho arbitrário', estipulado por cronogramas em equipe.

E além das medidas legais que incentivam o prolongamento das jornadas, uma estratégia de gestão que atua em consonância com a lei e colabora diretamente com esse processo de reestruturação das empresas e corte de custos, modificando o paradigma do tempo limite para a exploração do trabalho alheio, é a intensificação das atividades diárias, acentuando a carga de trabalho. Mesmo o trabalho mais estável, como se verá através dos casos avaliados, está sofrendo uma pressão em direção à intensificação sem precedentes à plena disponibilidade para uma submissão aos mais diversificados horários de trabalho, o que aparentemente parece 
uma liberação do tempo de trabalho, mas na realidade inaugura uma nova trama de poder e controle. "As organizações flexíveis hoje estão fazendo experiências com vários horários do chamado 'flexitempo'. Em vez de turnos fixos, que não mudam de mês para mês, o dia de trabalho é um mosaico de pessoas trabalhando em horários diferentes, muitas vezes individualizados, totalmente a mercê do empregador" (SENETT, 2008).

A jornada flexível, como visto, se define de várias maneiras. A mais simples, usada de alguma forma por cerca de $70 \%$ das empresas americanas, é o trabalhador realizar uma semana integral de trabalho, mas informando previamente ao empregador quando, durante o dia, estará no local de trabalho. No extremo oposto, cerca de $20 \%$ das empresas permitem horários de trabalhos 'comprimidos', como quando o empregado faz o trabalho de toda uma semana em quatro dias. Trabalhar em casa é hoje uma opção em cerca de $16 \%$ das empresas, sobretudo para trabalhadores em serviços, vendas e técnicos, o que se tornou possível em grande parte devido ao desenvolvimento das redes internas de comunicação. Os trabalhadores trocam assim uma forma de submissão ao poder - cara a cara - por outra, eletrônica, o que revela que o tempo nas instituições e para os indivíduos não foi libertado da jaula de ferro do passado, mas sujeito a novos controles do alto para baixo.

Por meio dos novos sistemas de comunicação, especialmente pelo telefone móvel e pela Internet, os trabalhadores ficam à disposição de um patrão remoto que os alcança a qualquer hora do dia ou da noite e o tempo de trabalho invade os tempos de não-trabalho, afetando a vida individual e coletiva do trabalhador. O trabalho flexível traduz-se em jornadas imprevisíveis, alternando tempos ociosos e trabalhos intensos, já que habitualmente as tarefas encomendadas deverão ser executadas em tempos mínimos. E paralelo a todas essas inovações organizacionais, o fenômeno do prolongamento das horas trabalhadas é, ainda, uma estratégia adotada pelas empresas no momento em que a correlação de forças lhe é favorável, como evidenciado no processo que culminou com a introdução do banco de horas na CLT. Parafraseando Sennett, demonstrando que as práticas de flexibilidade, porém, concentram-se mais nas forças que dobram as pessoas.

O tempo para o capital só interessa na medida que aloca e realoca trabalho para tarefas segundo vigorosos ritmos de mudança tecnológica e gestacional forjados pela busca incessante de acumulação do capital. É imprescindível reduzir o tempo de giro do capital, que é o tempo de produção, associado com o tempo de circulação da troca, visto que quanto mais rápida a recuperação do capital posto em circulação, tanto maior o lucro obtido. O capitalismo tem sido caracterizado, devido a esse raciocínio, por contínuos esforços de redução dos tempos de giro. As mudanças organizacionais das últimas décadas, tais como o sistema de entrega just in time, 
quando associadas com novas tecnologias de controle eletrônico, de produção em pequenos lotes e a robotização, reduziram os tempos de giro em muitos setores da produção (eletrônica, máquinas-ferramenta, automóveis, construção, vestuário, etc.). Para os trabalhadores, tudo isso implicou em uma intensificação dos processos de trabalho gerando uma tensão pelo máximo de eficiência.

\footnotetext{
É considerável a tensão do desempenho gerencial num tal ambiente, gerando todo tipo de efeito colateral, tal como o chamado 'resfriado yuppie' (uma condição de estafa psicológica que paralisa a ação de pessoas talentosas e produz duradouros sintomas semelhantes ao do resfriado) ou o frenético estilo de vida dos operadores financeiros, cujo vício de trabalhar, longas horas de trabalho e corrida pelo poder fazem deles excelentes candidatos para a mentalidade esquizofrênica (SENNETT, 2008).
}

Hoje, considerando um período de tempo relativamente curto que responde ao anseio pela redução do tempo de giro do capital, o trabalho é mais intenso, o ritmo e a velocidade são maiores, a cobrança de resultados é mais forte, assim como a exigência de versatilidade do trabalhador, provocando um maior desgaste físico, intelectual e emocional do indivíduo que trabalha. A versatilidade aliada a polivalência, faz com que o trabalhador se desdobre em várias tarefas sucessivamente, de tal forma que lhe seja praticamente impossível usufruir de intervalos de descanso. Ao mesmo tempo, o grau de exigência na realização das tarefas imprime ao trabalhador uma autocobrança sem limites, estimulada pelos programas de qualidade total e bonificação por rendimento. A intensidade torna-se, portanto, mais que esforço físico, pois envolve todas as capacidades do trabalhador, sejam as de seu corpo, a acuidade de sua mente, a afetividade e o comprometimento despendido ou os saberes adquiridos através do tempo ou dos processos educativos e de socialização.

No entanto, a intensificação não ocorre somente nas atividades industriais. Em todas as atividades que concentram grandes volumes de capital e que desenvolvem uma competição sem limites e sem fronteiras, tais como nas atividades financeiras e bancárias, telecomunicações, grandes cadeias de abastecimento urbano, nos sistemas de transportes, nos ramos de saúde, educação, cultura, esporte e lazer e em outros serviços que demandam mais pelas capacidades intelectuais e emocionais, o trabalho é cada vez mais cobrado por resultados e por maior envolvimento do trabalhador.

O processo de apropriação do tempo de vida do trabalhador é cumulativo, à medida que atualmente os trabalhadores precisam acrescentar aos gastos tradicionais de energias físicas, o gasto de energias intelectuais e psíquicas. $\mathrm{O}$ efeito do acúmulo indica que o trabalho é, por um lado, explorado mais intensamente e, por outro, que os desgastes dos trabalhadores 
se ampliam para fronteiras do mundo da atividade que antes não eram mobilizadas com tanta constância.

O ponto de partida para o sistema Toyota consistia na crítica ao desperdício que identificava com o modelo fordista. Apontava a superprodução, os tempos de espera, os transportes desnecessários, os processos de fabricação, os estoques não vendidos, as idas e vindas e os defeitos de produção como perdas. A listagem dos desperdícios do sistema fordista não incluía uma referência direta ao trabalhador, entretanto era a rigidez que a especialização profissional envolvia para a fábrica, a rigidez que o emprego de um trabalhador por máquina conferia à produção, o número de trabalhadores empregados, que o novo modelo procurava combater. A ideia era aumentar fortemente o grau de eficiência da mão-de-obra, através da bandeira de reduzir a zero o trabalho que não agregasse valor, através da redução de efetivos, estímulo a polivalência, ao acúmulo de funções e a intensificação no cumprimento das tarefas, produzindo apenas o necessário.

Com o intuito de superar o modelo fordista, a Toyota passou a experimentar, a partir dos anos de 1950, a produção a tempo certo, o que exigiu uma inversão total na relação entre produção e sistema de consumo. Em época de estagnação econômica, a produção ficava a reboque do que o mercado consumia, só produzindo exatamente no momento e na quantidade determinada pela demanda. Nesse processo de adequação, só se exigiria horas extras da força de trabalho nos períodos necessários. Esse é um primeiro elemento do sistema toyotista que tem influência sobre a intensidade, ao mesmo tempo em que marca uma mudança de paradigma, com a tradução legal do mecanismo na estipulação de um banco de horas. Mantido um contingente mínimo de força de trabalho, a elevação da demanda é satisfeita mediante um trabalho mais intenso e também com o emprego de horas extras e com a contratação adicional temporária, nos moldes da flexibilização em curso.

\section{A desregulamentação proposta com a Lei 13.467 de 2017}

A concepção do trabalho no mundo contemporâneo vem sofrendo sucessivas ressignificações, desde o modelo fordista de produção baseado na linha de produção de fábrica, passando pela fórmula toyotista just in time, baseada no enxugamento e na ausência de desperdício até o capitalismo baseado em redes (CASTELLS, 1996), onde a reestruturação capitalista, impulsionada pelas novas tecnologias da informação e da comunicação, 
denominado por Castells como Capitalismo Informal, baseado na geração de conhecimento com base no processamento da informação como engrenagem da produtividade.

O trabalho hoje se distancia do chão de fábrica de onde se inspirou o texto celetista de 1943 para chegar ao chamado gig economy, onde se exige a cada dia mais liquidez no perfil do trabalhador, fenômeno universalmente verificado (BAUMAN, 2001), onde o perfil ideal de empregado é o que não se atém a amarras, a contratos, que seja capaz de se adaptar a novas exigências e atividades laborais e não fazer reclamos, que seja enfim resiliente às novas mudanças da Economia e de suas novas demandas

O contrato de trabalho intermitente introduzido pela Lei 13.467 de 2017 estabeleceu uma nova modalidade de contrato outrora não existente, uma vez que as modalidades previstas pela Consolidação das Leis do Trabalho previam apenas as formas determinada ${ }^{5}$ e indeterminada, essa última como a regra a ser seguida em qualquer contrato de trabalho.

A Lei 13.467 de 2017 introduziu a nova forma contratual do contrato intermitente ao fim do artigo 443 da CLT. Nesse sentido, considera-se como intermitente o "Contrato de Trabalho no qual a prestação de serviços, com subordinação, não é contínua, ocorrendo com alternância de períodos de prestação de serviços e de inatividade, determinados em horas, dias ou meses, independentemente do tipo de atividade do empregado e do empregador, exceto para os aeronautas, regidos por legislação própria".

O trabalhador poderá prestar serviços de qualquer natureza a outros tomadores de serviço, que exerçam ou não a mesma atividade econômica.

O contrato intermitente veio a regulamentar a crescente prática de naturalizar o trabalho temporário e precarizado não legalizado, o famoso "bico". Com isso, a real proposta da "Reforma Trabalhista", ao contrário do argumento da geração de empregos, passou a ser a redução do tempo morto de trabalho, pelo aproveitamento máximo de toda sobra de tempo para direcioná-lo à produção, flexibilizando jornada com a consequente paga da remuneração.

O tempo "ocioso" em que o empregado se utilizava para o deslocamento de sua residência até o local de trabalho, seja por transporte ofertado por serviço público, seja ofertado

\footnotetext{
${ }^{5}$ Art. 443 CLT $\S 1^{\circ}$. Considera-se como de prazo determinado o contrato de trabalho cuja vigência dependa de termo prefixado ou da execução de serviços especificados ou ainda da realização de certo acontecimento suscetível de previsão aproximada.

$\S 2^{\circ}$. O contrato por prazo determinado só será válido em se tratando:

a) de serviço cuja natureza ou transitoriedade justifique a predeterminação do prazo;

b) de atividades empresariais de caráter transitório;

c) de contrato de experiência.

Além da previsão do art. 443 da CLT há a Lei 9.601/1998, que determina que as convenções e os acordos coletivos de trabalho poderão instituir contrato de trabalho por prazo determinado, de que trata o art. 443 da CLT, independentemente das condições estabelecidas em seu $\S 2^{\circ}$, em qualquer atividade desenvolvida pela empresa ou estabelecimento, devendo gerar, obrigatoriamente, aumento de postos de trabalho.
} 
pelo empregador para possibilitar o trabalho em local de difícil acesso, as denominadas horas in itinere ${ }^{6}$, seja o tempo despendido para o preparo para o trabalho, como a pausa do café da manhã, utilização de uniformes, maquiagem, higiene pessoal, eram considerados anteriormente à edição da Lei 13.467 de 2017 integrantes da jornada de trabalho do empregado, como tempo à disposição do empregador, computando para a soma da jornada final, salvo nas condicionantes previstas na própria Lei, como o artigo 58 parágrafo $1^{\circ}$ do antigo texto celetista, que previa o cômputo integral na jornada após a ultrapassagem do dez minutos que antecedem ou sucedem a jornada diária.

A Lei 13.467 de 2017 pôs fim a todos os hiatos existentes da jornada de trabalho através da modalidade do contrato intermitente, seja pelo tempo à disposição do empregador, aguardando ordens, seja no tempo de preparo para o trabalho diário, tais lapsos temporais não mais comporão o cálculo da jornada diária, sendo substituída unicamente pelo tempo efetivamente trabalhado computado por horas, dias ou meses.

Disso resulta que a regra clássica do Direito do Trabalho, que privilegia o contrato por prazo indeterminado, de trato sucessivo e de relação continuada, sofreu uma forte desregulamentação com a entrada em vigor do contrato intermitente.

Ao remunerar o empregado unicamente pelo tempo de trabalho vivo, exceptuando os períodos sem necessidade de labor, ao empregado resta aguardar quando uma nova oportunidade de trabalho irá surgir, enquanto suas necessidades pessoais e de sua família permanecem vencíveis a cada mês, trazendo um clima de insegurança e ansiedade que a forma indeterminada de prazo sempre prezou por distanciar e proteger.

A nova técnica afasta até mesmo o problema gerado pela mensuração da jornada, uma vez que a remuneração se dá única e exclusivamente pelo tempo de trabalho despendido, colocando por termo a questão da porosidade do tempo morto, uma vez que a remuneração se dá a cada fim de lapso temporal laborado, sendo quitados de forma proporcional a remuneração em si, o FGTS, os recolhimentos previdenciários, as férias acrescidas de um terço, o décimo terceiro salário, o repouso semanal remunerado e os adicionais legais.

Vale o registro que, com o término da vigência da Medida Provisória 808 de 2017, aos 23.04.18, ante a ausência de votação por parte do Congresso Nacional, questões importantes como a rescisão do contrato terminaram por restar sem regulação, permanecendo o texto original de pagamento da remuneração e algumas verbas de natureza contratual após cada

\footnotetext{
${ }^{6}$ Conforme Súmula 90 do TST - Horas in itinere. Tempo de serviço. [...] V - Considerando que as horas in itinere são computáveis na jornada de trabalho, o tempo que extrapola a jornada legal é considerado como extraordinário e sobre ele deve incidir o adicional específico.
} 
término de período de prestação de serviços, sem haver previsão de verbas de natureza rescisória.

A versatilidade aliada a polivalência exige que o trabalhador realize diversas tarefas ao mesmo tempo, fazendo com que seu tempo de trabalho formal seja convertido em trabalho real, eliminando os tempos de trabalho 'morto' das jornadas, o que vem sendo acompanhado pelo Direito nas medidas desreguladoras como a do contrato intermitente, que determina pagamento de algumas verbas contratuais após o efetivo tempo de trabalho, deixando à margem um dos pilares de sustentação da normatividade laboral, qual seja, o cômputo da jornada de trabalho prevista na Constituição Federal da República.

Dessa forma, a polivalência se traduz em um componente a mais de intensificação, à medida que requer um esforço adicional de trabalho mental, conhecimento de operações diversas, trabalho emotivo, concentração e atenção na execução de tarefas diversas. $\mathrm{O}$ interessante a respeito desse processo de intensificação, é que o trabalho contemporâneo é herdeiro de uma jornada normalmente mais reduzida em número de horas trabalhadas, mas também de um grau de intensidade muito maior do que em épocas passadas, atendendo a lógica de compensação do capital para assegurar sempre um maior lucro. E nesse movimento, ao incorporar mudanças tecnológicas (computadores portáteis, telefones móveis...), as próprias alterações são fatores de intensificação por exigir maior desempenho dos trabalhadores.

Também é possível promover a intensificação a partir da fragmentação dos horários, o aumento do número de horas por turno e a dissociação dos tempos do homem dos tempos das máquinas. A fragmentação é possibilitada pela adoção das jornadas flexíveis. A transformação delas em mensais ou anuais facilita reformatar as durações diárias. As distribuições do tempo são variáveis entre trabalho real e trabalho livre.

Duas horas de trabalho pela manhã, três pela tarde, duas à noite. São situações muito presentes na telemanutenção, nos consertos, no trabalho docente, na distribuição por atacado e no teletrabalho. Fragmentando, evita-se o desgaste e a consequente redução do ritmo quando o horário é contínuo. A tendência de aumento do número de horas por turno, por sua vez, consiste em aumentar a quantidade de tempo ininterrupto de trabalho. E por fim, a dissociação dos tempos dos homens dos das máquinas é bastante empregada nos grandes negócios, incluindo trabalho em horários atípicos, como durante a noite e nos feriados.

Dados publicados pelo sociólogo Sadi Dal Rosso em seu livro 'Mais Trabalho!' revelam que dos vinte ramos considerados em seu levantamento, oito indicam que o trabalho hoje é mais intenso do que na época em que começaram a trabalhar, sendo eles a atividade bancária e financeira, telefonia e comunicação, indústria gráfica, educação privada, serviços 
especializados, saúde privada, transporte rodoviário e serviço público federal. Dos citados, o alongamento das jornadas é vivenciado particularmente pelos setores de bancos e finanças e ensino privado. Já no ramo da telefonia e comunicações o mecanismo preponderante de maior exploração da força de trabalho tem sido a intensificação através do aumento do ritmo e da velocidade na realização das tarefas diárias.

Na telefonia e comunicação, o ritmo e a velocidade se aceleram através da introdução da tecnologia. Além de elevar o ritmo, os computadores permitem uma distribuição tal das chamadas que os microtempos de descanso dos quais os telefônicos se beneficiavam praticamente desapareceram. Os computadores modernos, os programas e os softwares exercem um controle implacável sobre o trabalho cotidiano por meio de um prosaico sistema de 'pontuação', que pode servir como subsídio para avaliação de desempenho e remuneração por produtividade, quando não como ameaça de perda do emprego. A informática permitiu igualmente melhorar aquilo que o cronômetro realizava, sem cumprir a promessa de libertar o homem ampliando seu tempo livre. A tecnologia que deveria poupar trabalho, em especial as tecnologias de informação e comunicação, mede sem piedade a produtividade do trabalho, confirmando o locus do poder.

O contrato intermitente veio referendar a busca pela quitação exclusiva da jornada efetivada, ainda que intensificada, de forma a acabar com os hiatos da jornada. A proposta inicial de que a nova modalidade poderia alavancar os postos de trabalho não restou configurada, pois na amostragem realizada pelo IBGE na pesquisa contínua da Pnad, referente ao trimestre janeiro-março de 2018, os índices indicavam um percentual de desemprego de 13,1\% referente a 13, 7 milhões de desempregados no País, caracterizando a terceira alta consecutiva após nove trimestres de queda.

Verifica-se, portanto, que o advento do contrato intermitente, após a vigência da "reforma", aos 11.11.17, não alavancou os postos de trabalho como previa o Governo Federal, tendo como principal consequência em realidade a extirpação da porosidade do trabalho, antigo reclamo do empresariado brasileiro.

\section{Conclusão}

A denominada reforma trabalhista instituiu uma nova modalidade de contrato de trabalho, o contrato intermitente, sob o argumento de geração de empregos. Para tanto, o empregador quita ao empregado o que ele efetivamente despendeu de tempo de vida em prol do trabalho, além das verbas de natureza contratual devidas em função da lei. 
A cada hora de trabalho, uma remuneração e um pagamento de direitos laborais. Não havendo necessidade de trabalho, o empregado permanece em sua casa, sem remuneração, ou, ainda, trabalhando para outros empregadores, em uma indubitável forma precarizada regulada pelo Direito do Trabalho.

Os tempos da jornada de trabalho à disposição do empregador não mais passaram a ser remunerados, o que vai de encontro a toda legislação protetiva laboral brasileira e o modelo clássico de contrato de trabalho, por tempo indeterminado e sucessivo.

A autorização de uma jornada móvel pelo Direito sem dúvida confronta com a enorme insegurança jurídica que tal disposição acarretará ao empregado e sua subsistência, já que necessita do seu salário para fazer frente a suas despesas pessoais e de sua família, gerando ansiedade, desconforto, imprevisibilidade e desregulamentação jurídica em última análise.

Se ao empregador compete o ônus da assunção do risco do negócio, de acordo com a clássica disposição dos artigos $2^{\circ}$ e $3^{\circ}$ da CLT em interpretação sistêmica, a nova modalidade contratual terminam por repassar ao empregado o ônus empresarial, uma vez que somente é efetuada a quitação da remuneração se houver trabalho.

O trabalhador intermitente regulamentado pela "Reforma" em muito se assemelha ao trabalhador autônomo, este sim, laborando pelo tempo vivo de trabalho, onde não há tempo à disposição do empregador. Mais ainda, não se trata sequer de um trabalhador autônomo, mas sim de um trabalhador precarizado, que recebe a paga correspondente a cada novo posto de trabalho, o famoso "bico" ou no vocabulário neologista e estrangeirizado, o famoso "freelancer", que anteriormente atingia profissionais liberais autônomos e agora pode atingir qualquer categoria profissional, à exceção dos aeronautas.

Ao contrário das promessas governamentais, o contrato intermitente não recrudesceu os postos de trabalho, ao revés, aumentou os números de desemprego no Brasil conforme dados estatísticos oficiais.

Verifica-se portanto que a ideia da jornada móvel afasta do empregado um dos pilares de proteção mais preciosos do Direito do Trabalho historicamente protegido: a jornada de trabalho com a inclusão do tempo à disposição do empregador e todos os lapsos temporais devidos em função da jornada.

Esta desregulamentação do Direito atende a um antigo anseio do empresariado de quitar ao empregado única e exclusivamente o tempo de trabalho realizado, ainda que com acréscimo de verbas contratuais, tornando a flexibilização das regras do Direito do Trabalho patentes, à medida em que a regra tradicional do contrato a prazo indeterminado convive legalmente em paralelo ao novo trabalhador "autônomo empregalizado". 
A existência ou não de uma próxima chamada ao trabalho dependerá do mercado, quebrando a sucessividade contratual laboral.

O tempo morto de trabalho certamente foi extirpado com a nova modalidade contratual, sendo certo que esta foi a única hipótese verificada após o advento da novel modalidade.

Com as novas imposições mercadológicas neoliberais, o Direito vem se curvando aos ditames da era gig economy, onde o trabalhador deve ser resiliente, versátil, adaptável a novas demandas e jornadas, sejam elas intensificadas, sejam elas enxutas, sejam elas baseadas no just in time taylorista, reconstruindo a subjetividade do trabalhador para encaixe ao mercado, distanciando-se dos preceitos constitucionais mais basilares previstos na Constituição Federal de 1988 em seus artigos $6^{\circ}$ e $7^{\circ}$.

A medida levada a efeito pelo atual Governo Federal não alcançou o objetivo de geração de empregos previsto na exposição de motivos da Lei 13.467 de 2017 e trará certamente muita insegurança jurídica para os trabalhadores brasileiros, agora desprotegidos da regra da indeterminação do prazo do contrato de trabalho, sem parcelas vencíveis mês a mês, sem sucessividade, no aguardo de um novo tempo de trabalho vivo, a depender do mercado.

\section{Referências bibliográficas}

BAUMAN, Zigmunt. Modernidade líquida. São Paulo: Zahar. 2001.

BOLTANSKI, Luc e CHIAPELLO, Ève. O novo espírito do capitalismo. “Transformações do Capitalismo e desarmamento da crítica" e "Rumo a dispositivos conexionistas de Justiça?" São Paulo: Martins Fontes, 2009.

CASTELLS, Manuel. A sociedade em rede. São Paulo: Paz e Terra. 1996.

DAL ROSSO, Sadi. Mais Trabalho! São Paulo: Boitempo, 2008.

FERREIRA, António Casimiro. Para uma concepção decente e democrática do trabalho e dos seus direitos: (Re)pensar o direito das relações laborais. In: A Globalização e as ciências sociais. Boaventura de Souza Santos (org.) 2a ed., São Paulo, Cortez, 2002. Sociedade da austeridade e direito do trabalho de exceção.

Porto: Vida Económica, 2012. 
HARVEY, David. Condição Pós-Moderna. São Paulo: Edições Loyola, 2008, p. 211.

MARX, Karl. O Capital. Rio de Janeiro: Civilização Brasileira, 2011, p. 61.

SANTOS, Boaventura de Souza. Os processos de globalização. In: A Globalização e as Ciências Sociais. 2a ed. São Paulo: Cortez, 2002, p. 25-102.

SENNETT, Richard. A Corrosão do Caráter. Rio de Janeiro: Record, 2008.

SILVA, Sayonara Grillo Coutinho Leonardo. Relações Coletivas de Trabalho -. configurações institucionais no Brasil contemporâneo. São Paulo: LTr, cap. II. 2008.

SUPIOT, A. Critique du droit du travail. Paris: Puf, 1994.

TAYLOR, Frederick Winslow. The Principles of Scientific Management. Nova York: Norton and Company, 1967.

Constituição da República Federativa do Brasil de 1988.

Sítio consultado <www.ibge.gov.br $>$ acesso aos 14.05.2018. 


\title{
O DUMPING SOCIAL E A PRECARIZAÇÃO GLOBAL DAS RELAÇÕES DE TRABALHO
}

\author{
Augusto Eduardo Miranda Pinto \\ Universidade Estácio de Sá \\ Leonardo Gama Alvitos \\ Universidade Estácio de Sá
}

\begin{abstract}
Resumo
O dumping social representa atividade comercial ilícita que se caracteriza pela tentativa de eliminação dos concorrentes através da competição injusta. Tal prática provoca desequilíbrio nas relações de mercado além de fragilizar todo o sistema de proteção aos direitos do trabalhador. Na esfera internacional a busca pela maximização dos lucros faz com que as empresas se desloquem com frequência de seus locais de origem para além das fronteiras, passando a desempenhar suas atividades em países que estabelecem encargos sociais mais baixos, terminando por trazer a precarização das relações laborais no seu todo, ocasionando a ausência de garantia de padrões trabalhistas mínimos.
\end{abstract}

Palavras-chave: Dumping, Precarização, Concorrência.

\begin{abstract}
Resumen/Résumé
The social dumping represents the illicit commercial activity which is characterized by the attempt to eliminate competitors through unfair competition. This harmful practice causes an imbalance in economic relations and weakens the whole system of protection of employees rights. At the international level, the search for profit maximization often causes firms to move from their places of origin beyond their borders to work in countries that set lower social charges, leading to the precariousness of labor relations as a whole, leading to the absence of a guarantee of minimum labor standards.
\end{abstract}

Keywords/Palabras-claves/Mots-clés: Dumping, Precariousness, Competition. 


\section{Introdução}

O dumping social, termo utilizado na esfera internacional com um significado meramente econômico no qual um determinado país introduz produtos a preços inferiores a seu custo normal no mercado de outro país, provocando uma situação de concorrência desleal, diferencia-se do conceito do mesmo instituto introduzido na esfera laboral, sendo neste último caso, uma adaptação baseada na utilização da mão de obra mais barata e custos trabalhistas menores, com os seus padrões trabalhistas mínimos desrespeitados pelo empregador, a fim de provocar a maximização do lucro.

Internacionalmente é nítida e imperiosa a compatibilização entre as relações comerciais externas, os direitos fundamentais dos trabalhadores e o princípio da concorrência desleal nas relações comerciais. Destaque-se que a tendência central da política externa comercial é facilitar a entrada nos mercados de outros países, o que demanda em contrapartida a obrigatoriedade de abrir os próprios mercados determinando o atendimento das normas globais, principalmente aquelas provenientes da Organização Mundial do Comércio.

No Brasil, o ordenamento jurídico define a prática de dumping, que tem uma vertente de interiorização no ordenamento jurídico laboral, como sendo o desrespeito da legislação laboral em benefício do lucro do empregador com sacrifício das obrigações legais (entre outras, cumprimento de normas de segurança e saúde) e encargos sociais, o que acarreta o fornecimento de produtos a um preço menor, favorecendo comercialmente a empresa perante sua concorrência, podendo o Juiz de oficio declarar tal ilício, impondo a indenização e multa relacionadas.

O método de trabalho adota a metodologia dialética, a partir da produção de conhecimento através de uma pesquisa bibliográfica, com consulta a doutrina mais relevante ao tema. As ações neste caso serão efetuadas por intermédio de uma análise do ordenamento jurídico vigente e sua interpretação formada pelos tribunais e doutrina, nacional e internacional, buscando-se pôr em evidência suas possíveis contradições e problemas a fim de que sejam conclusivamente ultrapassados.

O presente artigo tem como tema central o enfrentamento de questões que permanecem em aberto, tais como: a valoração da infração laboral, o que leva ao questionamento se o não cumprimento da legislação de saúde ou segurança representa mais desvalor que o atraso no pagamento dos salários; a caracterização do dumping no caso da prática destas condutas por 
empresas que não tem concorrência no mercado; a necessidade da prova do lucro ou da vantagem nas empresas que inegavelmente realizam concorrência desleal; e a possibilidade do caráter pedagógico encarecer a indenização pelo dano.

O trabalho justifica-se na medida em que representa mais um instrumento de combate a tal prática ilegal, que além de prejudicar o trabalhador em sua esfera individual, ainda ocasiona um efeito cascata no âmbito coletivo, na medida em que outras empresas tendem a deixar de cumprir as normas trabalhistas para que possam sobreviver concorrencialmente, afetando a estrutura mercadológica do modelo capitalista, reverberando ainda mais a precarização dos direitos laborais básicos.

\section{Dumping na esfera internacional}

O termo dumping utilizado na esfera internacional tem uma conotação econômica, em que um determinado país introduz produtos a preços inferiores a seu custo normal, em outro país. Difere do conceito introduzido na esfera laboral, sendo uma adaptação baseado na utilização da mão de obra mais barata e custos trabalhistas menores, com os seus padrões trabalhistas mínimos desrespeitados pelo empregador, afim de ocorrer a maximização de lucro.

A definição jurídica de dumping no comércio internacional surgiu no art. VI do GATT (General Agreement on Tarifes and Trade) ${ }^{1}$, que definia o mesmo como a discriminação de preços entre compra em diferentes mercados nacionais, o que parte da doutrina define como vender produtos a preços inferiores aos custos, afim de eliminar concorrentes e aumentar participação do mercado. Evidente que a definição em si não esgota a configuração do instituto, é importante provar-se a sua existência a partir do nexo causal entre a conduta do agente e o dano sofrido, bem como a frequência de sua ocorrência.

Ainda que relevante a regulamentação do dumping social representados pelo GATT que permitiram o desenvolvimento do mercado global, eles de fato elaboraram uma definição de dumping que corresponde apenas a análise de preço, que se caracteriza pela venda de determinada mercadoria no mercado estrangeiro por um preço inferior àquele praticado no mercado de origem ou através da venda por um preço insuficiente para arcar com os custos de

\footnotetext{
${ }^{1}$ As partes contratantes reconhecem que o dumping que introduz produtos de um país no comércio de outro país, por valor abaixo do normal, deve ser condenado se causa ou ameaça causar prejuízo material a uma indústria estabelecida no território de uma parte contratante, ou se retarda, sensivelmente, o estabelecimento de uma indústria nacional.
} 
produção. Tal posição não analisa os interesses sociais dos países analisados, com a utilização de instrumentos multilaterais e supranacionais.

Para resolver este problema a OMC e a OIT (Organização Internacional do Trabalho) propõe a inserção de cláusulas sociais nos tratados comerciais internacionais, em vista ao desenvolvimento de um capitalismo responsável socialmente. A OMC neste contexto consta com maior poder de convencimento para estabelecer as referidas cláusulas, em virtude da coercibilidade de suas decisões, já a OIT depende da boa vontade de seus membros ratificarem suas convenções, o que em alguns casos não surge o efeito necessário. Há também a opção de acordos bilaterais, estas e outras alternativas visam criar os pressupostos para se estabelecer um ambiente de negociação a partir de um critério de avaliação do direito internacional do trabalho com garantias mínimas aos trabalhadores, de modo a ser obrigatório para os estados aderentes, a partir das convenções internacionais.

A introdução das cláusulas sociais enseja controvérsias, tendo em vista que os países em desenvolvimento acusam a admissão das referidas cláusulas como forma de protecionismo. Não consideram a utilização de mão de obra mais barata como dumping social, mas alegam que essa justificativa é apenas uma maneira dos mais desenvolvidos poderiam excluir da competição internacional a vantagem competitiva no jogo econômico. Por outro lado, os mais desenvolvidos com elevado nível de proteção laboral afirmam que os menos desenvolvidos utilizam uma concorrência desleal para oferecer produtos mais baratos, e que deve ser coibida tal prática sob pena de inviabilizar seus próprios negócios.

O dumping social, basicamente, trata-se de prática comercial ilícita que se caracteriza pela tentativa de eliminação dos concorrentes através da competição injusta. "Prática de comércio internacional consistente na venda de mercadorias em praça estrangeira por preço sistematicamente inferior ao do mercado interno ou ao de produtos concorrentes, tendo como fito a eliminação de concorrência”. (PINTO, 2011, p.137). Ele pode ocorrer em relação a empresas transacionais e locais, e também em relação a empresas dentro de um único país. Não são em todos os casos que o dumping é aplicável, existem situações que a venda de um produto em um país em preço inferior a outro não é condenável, principalmente em função da sua baixa sazonalidade, o que não ensejaria ameaças as indústrias da nação exportadora. Para consideração desse instituto é necessária uma prática reiterada que vise eliminar a concorrência ou prejudica-la, em função de preços artificialmente mais baixos.

No âmbito internacional há necessidade de se compatibilizar a correlação entre relações comerciais externas e direitos fundamentais dos trabalhadores com o princípio de concorrência desleal nas relações comerciais, que está de acordo com o princípio da não 
discriminação previsto na constituição global do comércio internacional (art. I do GATT). Nesse contexto ressaltamos que o tema central da política externa comercial é facilitar a entrada nos mercados de outros países, o que exige a contrapartida de abrir os próprios mercados o que obriga seguir as regras das normas globais, principalmente da OMC (Organização Mundial do Comércio), começando pelo 'Acordo de Marrakesh', que se baseia em uma regulação imperativa, ainda que prestigiando a liberação comercial.

No médio e longo prazo pode tal posição acarretar o crescimento econômico, porém, no curto prazo pode afetar alguns setores de bens e serviços, salvaguardados pela proteção tarifária, que não resistem a competição externa. Nesse aspecto, pode haver o deslocamento para empresas países com menores custos de produção, como: ambientais e laborais, o que poderia acarretar um nivelamento dos custos para um patamar abaixo dos padrões mínimos como: quanto a dignidade do trabalhador e a exigência de um meio ambiente sadio, previstas em muitas constituições, incluso a brasileira. Tal posição poderia acarretar de modo a proporcionar vantagens comerciais: a falta de reconhecimento de proteção dos mais elementares direitos laborais, o que poderia prejudicar a busca por um processo de integração social mínimo. (MOREIRA, 2014, p. 30, 33).

Há também uma disputa implícita entre sindicatos e organizações empresariais, os primeiros querem a introdução de cláusulas laborais para defenderem seus salários e benefícios, que podem ser prejudicados em relação a países com baixa proteção laboral, mas por outro lado se preocupam que outros países te $\mathrm{nham}$ uma proteção com condições dignas de trabalho, em uma universalização dos direitos fundamentais dos empregados. Todavia as empresas resistem em relação a estas cláusulas tendo em vista que em um ambiente comercial elas podem ficar em desvantagem perante aqueles que não fazem tais exigências, o que acarreta uma perda de mercado. Ademais, as combinações de baixos custos laborais, com um modelo de gestão eficiente, nos países subdesenvolvidos, proporcionariam maior investimento estrangeiro. (MOREIRA, 2014, p. 36).

No mercado globalizado há um processo de deslocalização para maximização de lucro. Há uma estratégia de diminuição de despesas a partir da busca por localidades que detenham encargos sociais mais baixos. Para exemplificar a precarização dos direitos laborais em busca de custos mais competitivos, temos que "as empresas canadenses falam em ir para os EUA, a dos EUA para o México e as mexicanas para a China" (VIANA, 2006, p. 30).

Os países desenvolvidos entendem que são vantagens competitivas ilegítimas no comercio internacional a utilização de custos salariais mais baixos, que na maioria das vezes se apresentam como resultantes de baixa produtividade mão de obra desqualificada. O maior risco 
do dumping social nestes casos é que os próprios países desenvolvidos podem caminhar para reduzir seus níveis de proteção laboral, o que acarretaria uma precarização global, em que as multinacionais passassem a procurar países com legislação laboral mínima, em uma corrida que até os países desenvolvidos seriam sujeitados a degradação geral dos direitos trabalhistas. Entretanto não há nenhuma prova que os baixos padrões de vantagens na legislação laboral favoreçam a competitividade dos países que optaram por este caminho, pois muitas das vezes o custo ganho é anulado pela baixa produtividade. (MOREIRA, 2014, p. 38-40).

Ademais, considerar a liberdade comercial como único parâmetro para descartar os direitos laborais vigentes atinge a própria ordem jurídica constitucional, por isso que determinadas práticas que atinge a dignidade da pessoa humana são rechaçadas pela sociedade, como: o trabalho escravo, infantil, a liberdade sindical e a vedação a discriminação. Não se pode radicalizar e considerar qualquer desrespeito à legislação laboral como caracterizador do dumping social, mas além do respeito aos direitos fundamentais já elencados anteriormente, deve-se estabelecer um freio para as reiteradas infrações laborais, que prejudicam o desenvolvimento econômico sustentável e a própria liberdade de comerciar sem uma concorrência desleal.

\section{Dumping social no ordenamento jurídico nacional}

No Brasil a aprovação da ata na Rodada do Uruguai de Negociações Comerciais e Multilaterais do GATT por meio do Decreto Legislativo n. 30, de 15 de dezembro de 1994, e a publicação da lei n. 9019, e regulamentação pelo Decreto n. 1602/95, inclui no ordenamento jurídico nacional a definição da prática de dumping, que tem uma vertente de interiorização no ordenamento jurídico laboral.

$\mathrm{Na}$ esfera trabalhista o dumping social corresponde ao desrespeito da legislação laboral em benefício do lucro do empregador com sacrifício das obrigações legais (entre outras, cumprimento de normas de segurança e saúde e encargos sociais), o que acarreta o fornecimento de produtos a um preço menor.

Outrossim, podemos tirar o conceito de dumping social na esfera laboral do projeto de lei n. 7070/2010², que afirma: “Art. $1^{\circ}$ Configura 'dumping social' a inobservância contumaz da legislação trabalhista que favoreça comercialmente a empresa perante sua concorrência”,

\footnotetext{
${ }^{2}$ http://www.camara.gov.br/proposicoesWeb/prop_mostrarintegra;jsessionid=3F178CB3BF0ABB782A0 6617E242CC44C.proposicoesWebExterno1?codteor=751937\&filename $=$ PL+7070/2010
} 
estabelece inclusive pagamento de indenização ao trabalhador prejudicado equivalente a 100\% (cem por cento) dos valores que deixaram de ser pagos durante a vigência do contrato de trabalho; pagamento de indenização à empresa concorrente prejudicada equivalente ao prejuízo causado na comercialização de seu produto e pagamento de multa administrativa no valor de $\mathrm{R} \$ 1.000,00$ (um mil reais) por trabalhador prejudicado, elevada ao dobro em caso de reincidência, a ser recolhida ao Fundo de Amparo ao Trabalhador - FAT, podendo o Juiz de oficio declarar tal ilício, impondo a indenização e multa relacionadas. A justificação do projeto é efetuada através do enunciado quatro da ANAMATRA (Associação Nacional do Magistrados Trabalhistas), aprovado durante a $1^{\text {a }}$ Jornada de Direito Material e Processual na Justiça do Trabalho, realizada em 2007 e ainda, aponta há necessidade das empresas concorrerem, dentro das regras estabelecidas, em especial as de ordem pública, como as normas trabalhistas. A não observação dessas normas ensejaria concorrência desleal, e as ações necessárias para evitar sua prática, seriam as multas estabelecidas no respectivo projeto, que foi arquivado pela Mesa da Câmara de Deputados, em 01/02/2011.

A adaptação do conceito de dumping social como dano social levanta ainda outras complexas questões. Analisar as condutas reiteradas para caracterização da infração é de difícil aplicação, pois tendo em vista a amplitude do termo, o juiz acaba ficando com a responsabilidade de defini-lo, o que gera insegurança jurídica. Algumas questões permanecem em aberto, a caracterização quanto a infração laboral, tem que ser valorado? Ou seja, o não cumprimento da legislação de saúde ou segurança é maior que o atraso de salário? A empresa que não tem concorrência, mas descumpre a legislação laboral com frequência, não caracteriza o delito? Mesmo a empresa que apresenta uma concorrência desleal, o lucro ou a vantagem para caracterização do delito, a mesma tem que ser provada? Até que ponto pode o caráter pedagógico encarecer a indenização do dano? Tentaremos explicitar estas questões no decorrer deste trabalho.

Para caracterização do dumping social devem ser analisados alguns pressupostos como: a concorrência desleal, a conduta reiterada e o descumprimento de padrões laborais mínimos, caracterizando o dano a sociedade como um todo (FERNANDEZ, 2014, p. 87-93). O primeiro tem como base o art. $170 \mathrm{IV}$ da CRFB, que se trata de prática comercial ilícita que se caracteriza pela tentativa de eliminação dos concorrentes através da competição injusta, o que enseja a concorrência desleal. Ela pode ocorrer em relação a empresas transacionais e locais, e também em relação a empresas dentro de um único país. A vantagem competitiva não está condicionada pela qualidade da formação de sua mercadoria, mas no preço que é vendida, e da impossibilidade do fornecimento deste bem nas condições oferecidas pelo mercado, salvo se a 
redução de custos decorrentes da mão de obra, seja produto da violação de direitos laborais. Ressalta-se que a mera diferenciação de preços não é suficiente para caracterização do instituto, pois a mesma poder ser resultante da modernização de equipamentos ou do aperfeiçoamento de técnicas de produção. Há necessidade de comprovar a concorrência ilícita a partir do descumprimento da legislação laboral.

O ilustre professor José Antônio Rodrigues Pinto, ao analisar algumas sentenças laborais, aponta que as mesmas não se enquadram no instituto analisado, tendo em vista que que apontam realmente o descumprimento da legislação laboral, todavia o descumprimento do contrato do trabalho foi "um fim em si mesmo e não um meio de extermínio de empresa (s) concorrente ( $s$ ). Logo, o dano social que respaldou as sanções não foi um efeito dumping, mas simples reflexo de dano individual dos empregados". (PINTO, 2011, p. 146).

A conduta reiterada, outro pressuposto para caracterização do dumping social, é necessária para verificação do dano social. Não ocorre em todos os casos que o dumping é aplicável, existem situações que a venda de um produto em um país em preço inferior a outro não é condenável, em função da sua baixa sazonalidade, o que não ensejaria ameaças as indústrias da nação exportadora. Para consideração desse instituto é necessária uma prática reiterada que vise eliminar a concorrência ou prejudica-la, em função de preços artificialmente mais baixos.

O último pressuposto a utilização de mão de obra em condições inadequadas aos patamares laborais mínimos, depende do ordenamento jurídico de cada país analisado. No Brasil os direitos laborais estão presentes no art. $7^{\circ}$ da CRFB. Ademais devem ser observados as convenções e acordos coletivos negociados com os trabalhadores. No âmbito internacional pode haver previsão de cláusula laboral ou cláusula social, pelo qual um determinado país, adota sanções que visa melhorar nos países exportadores, a condição de seus trabalhadores, adotando padrões mínimos, principalmente quanto a liberdade de trabalho, proibindo o trabalho forçado e infantil; e garantindo a liberdade sindical e a não discriminação no trabalho e emprego. Na União Europeia é tema de vital importância, harmonizando-se com a cláusula de direitos humanos na integração dos acordos comerciais lavrados em sua competência. (MOREIRA, 2016, p.16).

Ademais, tem que se verificar os chamados danos sociais, de modo que as lesões levantadas atinjam a sociedade como um todo, não somente do ponto de vista econômico, mas também pedagógico, tendo em vista que uma empresa que descumpre a legislação laboral cometendo a concorrência desleal sem maiores consequências, passa a mensagem que tal delito não tem relevância. Assim sendo, a caracterização do dano ainda que se observe no âmbito 
individual, seus efeitos são maiores no âmbito coletivo, com a extrapolação dos limites socioeconômicos do ato, tendo em vista que o descumprimento da legislação laboral impacta em lucro para a atividade ilícita, e vantagens concorrenciais que prejudicam o mercado como um todo. Do mesmo modo, tal prática ainda acarreta um efeito cascata, pois outras empresas tendem para sobreviverem concorrencialmente, a também não cumprirem as normas laborais afim de obterem preços competitivos, gerando um dano coletivo em todo mercado de trabalho, tanto para os empregadores que não conseguem uma concorrência justa, bem como os trabalhadores que tem direitos laborais básicos precarizados, afetando a estrutura do modelo capitalista.

Longas jornadas de trabalho, baixos salários, utilização da mão-de-obra infantil e condições de labor inadequadas são algumas modalidades exemplificativas do denominado dumping social, favorecendo em última análise o lucro pelo incremento de vendas, inclusive de exportações, devido à queda dos custos de produção nos quais encargos trabalhistas e sociais se acham inseridos. "As agressões reincidentes e inescusáveis aos direitos trabalhistas geram um dano à sociedade, pois com tal prática desconsidera-se, propositalmente, a estrutura do Estado Social e do próprio modelo capitalista com a obtenção de vantagem indevida perante a concorrência. A prática, portanto, reflete o conhecido 'dumping social ${ }^{3}$

Nessa ótica o dumping social trata-se de um dano coletivo, de cunho social, relacionado a direitos da terceira dimensão, chamados direitos transindividuais ou de solidariedade, portanto, relacionado a direitos difusos e coletivos. Tendo em vista que não há amparo no ordenamento jurídico para a manifestação do trabalhador individualmente, a reparação ou indenização por dano moral poderá ser judicializada por meio de ações pessoais, pelo substituto processual ou pelo Ministério Público do Trabalho, em juízo de primeiro grau, através das ações civis públicas ou ações civis coletivas; neste caso, apesar da controvérsia doutrinária, o valor da indenização será revertido não diretamente para os trabalhadores retirados da situação de dumping social, mas aos fundos que destinaram tais verbas para a reparação social do dano, que poderão ser "direcionados para instituições filantrópicas que prestam serviços aos trabalhadores, familiares, vulneráveis, idosos, crianças em situação de risco social, deficientes, ou que se dedicam à inclusão ou requalificação profissional." (SANTOS, 2015, p. 78-79).

\footnotetext{
3 Tribunal Regional do Trabalho da $4^{\circ}$ Região. Terceira Turma. RO-0131000-6320095040005. Relator: Des. Ricardo Carvalho Fraga. Data de Julgamento: 08.06.2011. Data de Publicação: 22.07.2011.
} 


\title{
4. Responsabilidade civil no dumping social
}

O art. 421 do Código Civil de 2002 dispõe que a liberdade de contratar será exercida em razão e nos limites da função social do contrato. A definição quanto a configuração do ato ilícito por abuso do direito e o dano à sociedade que submete o agressor a uma indenização suplementar está previsto nos arts. 186, 187, 404 e 927 do Código Civil. Ademais há previsão constitucional de valorização do trabalho, não somente no art. 170 , caput, bem como no art. $1^{\circ}$, IV, prestigiando a livre iniciativa, e no seu art. 193, elencando a ordem social como primado do trabalho, visando o bem-estar e a justiça social, o que enseja a proibição de práticas que ataquem a dignidade do trabalhador, e as práticas concorrenciais desleais, consoante o art. 170 IV da CRFB, o que embasa a caracterização do dumping social. No âmbito laboral tal dano social pode ser aplicado, todavia é necessário a configuração do dano coletivo impetrado, observando o histórico da empresa e o descumprimento da legislação trabalhista reiteradamente de modo a configurar o ilícito. O que corrobora o ANAMATRA, em sua $1^{\text {a }}$ Jornada de Direito Material e Processual realizada no final de 2007, produziu o tão afamado Enunciado n. 4, in verbis:

\section{DUMPING SOCIAL". DANO A SOCIEDADE. INDENIZAÇÃO SUPLEMENTAR.}

\begin{abstract}
As agressões reincidentes e inescusáveis aos direitos trabalhistas geram um dano à sociedade, pois com tal prática desconsidera-se, propositalmente, a estrutura do Estado social e do próprio modelo capitalista com a obtenção de vantagem indevida perante a concorrência. A prática, portanto, reflete o conhecido "dumping social", motivando a necessária reação do Judiciário trabalhista para corrigi-la. O dano à sociedade configura ato ilícito, por exercício abusivo do direito, já que extrapola limites econômicos e sociais, nos exatos termos dos arts. 186, 187 e 927 do Código Civil. Encontra-se no art. 404, parágrafo único do Código Civil, o fundamento de ordem positiva para impingir ao agressor contumaz uma indenização suplementar, como, aliás, já previam os artigos 652 , "d", e $832, \S 1^{\circ}$, da CLT
\end{abstract}

É importante definir a responsabilidade civil face ao dano social. Primeiramente devemos analisar o dano moral coletivo ou dano extrapatrimonial coletivo. Sendo este aquele que atinge lesão injusta a direito de titulares representados pela coletividade, possuindo natureza extrapatrimonial, que não necessariamente é representado pelo sofrimento atribuído a coletividade, mas é passível de vislumbrar uma ofensa moral que possa atingir a sociedade como um todo (MEDEIROS, 2007, p. 137,139), tal definição também é corroborada pelo art. $1^{\circ}$ da Lei 7347/85, bem como o art. $6^{\circ}$, VI e VII do Código de Defesa do Consumidor. Nesse sentido o importante é verificar a lesão aos direitos difusos ou coletivos, não importando o 
reflexo negativo do dano específico no patrimônio da coletividade, ainda que seja relevante a análise que os efeitos que tal dano possa produzir. Nesse sentido para o dumping social melhor a nomenclatura de dano social.

O dumping social interage no direito em três segmentos: o civil; quando analisa os contratos; o direito da empresa e o direito do trabalho; na medida que repercute na relação de emprego e nos custos da empresa e no direito consumerista, uma vez que afeta através da concorrência desleal, os preços das mercadorias. (PINTO, 2011, p. 141).

\begin{abstract}
Onde houver dano ou prejuízo, a responsabilidade civil é invocada para fundamentar a pretensão de ressarcimento por parte daquele que sofreu as consequências do infortúnio. É, por isso, instrumento de manutenção da harmonia social, na medida em que socorre o que foi lesado, utilizando-se do patrimônio do causador do dano para a restauração do equilíbrio rompido. Com isso, além de punir o desvio de conduta e amparar a vítima, serve para desestimular o violador potencial, o qual pode antever $\mathrm{e}$ até mensurar o peso da reposição que seu ato ou omissão poderá acarretar. (OLIVEIRA, 2013. p. 79).
\end{abstract}

$\mathrm{Na}$ análise da responsabilidade civil a repercussão do dano moral deve ser levada em conta no valor que deve ser arbitrado, conforme a doutrina mais tradicional: a extensão do dano, o grau de culpa do infrator, a participação da vítima, a capacidade financeira das partes, e em uma concepção adequado ao dano social: o caráter punitivo-pedagógico do ato lesivo, a reiteração da conduta em situações análogas e o impacto social originado.

Ademais, é importante ressaltar o caráter punitivo da responsabilidade civil em decorrência de condutas de elevada reprovação social, o que vai de encontro ao caráter solidarista da CRFB. Princípios como a proteção da dignidade do trabalho, a valorização do trabalho humano e a obrigatoriedade da busca e do compromisso intergeracional de um meio ambiente sadio, são indicadores da exigência de uma sanção quando não presentes estes postulados. (FERNANDEZ, 2014, p. 142).

O desrespeito deliberado e inescusável da ordem jurídica trabalhista representa inegável dano à sociedade (...) Portanto, nas reclamações trabalhistas em que tais condutas forem constatadas (agressões reincidentes ou ações deliberadas, consciente e economicamente inescusáveis) de não respeitar a ordem jurídica trabalhista (...) deve-se proferir condenação que vise à reparação pertinente ao dano social perpetrado, fixada ex officio pelo juiz da causa, pois a perspectiva não é de mera proteção do patrimônio individual. (SOUTO MAIOR, 2002, p. 1.319). 
A base legal da Responsabilidade Civil no âmbito do dumping social, encontra-se no art. 404, parágrafo único do Código Civil, em que se estabelece a possibilidade da cobrança de uma indenização suplementar, de caráter reparatório, punitivo e pedagógico, desde que comprovado o nexo de causalidade entre a conduta do empregador e o dano social. $\mathrm{O}$ dano deve ser comprovado através de ato ilícito pelo abuso do direito decorrente da atividade empresarial, sendo demonstrado o ato de concorrência desleal e o não cumprimento dos direitos trabalhistas, o qual deve repercutir além da demanda individual, caracterizando um dano social com repercussão na sociedade laboral. Essa indenização teria um caráter de 'punitive damages' retirada do direito norte americano, com uma função punitiva e preventiva, que teria como natureza jurídica o:

(...) acréscimo econômico na condenação imposta ao sujeito ativo do ato ilícito, em razão da sua gravidade e reiteração que vai além do que se estipula como necessário para satisfazer o ofendido, no intuito de desestimulá-lo à prática de novos atos, além de mitigar a prática de comportamentos semelhantes por parte de potenciais ofensores, assegurando a paz social e consequente função social da responsabilidade civil. (ROSEDÁ, 2009, p. 225).

Quanto a análise do 'punitive damages', Jose Antônio Rodrigues Pinto faz uma diferença desse instituto, que considera inicialmente como uma compensação punitiva, diretamente causada pelo empregado e indiretamente a sociedade, e por outro lado, como uma delinquência patronal caracterizada como uma reparação pecuniária ao dano diretamente causado ao empregado, com natureza de indenização compensativa, independente das reparações previstas na lei. O dumping neste caso se diferencia apenas de uma inexecução faltosa de relações bilaterais, ele é caracterizado pela eliminação da concorrência e o estrangulamento econômico, enquanto a delinquência patronal apenas pode caracterizar uma violação de direito entre dois partícipes de uma relação jurídica, "a conclusão é inevitável: enquanto a delinquência patronalpode ser um dos meios de exercício do dumping, o dumping dificilmente se completará com a simples prática da delinquência patronal." (PINTO, 2011, p. 151).

Parte da doutrina condena a função punitiva da responsabilidade civil em face do art. 944 do Código Civil, que se atém a medição e a extensão do dano, todavia não prospera tal tese, tendo em vista que na constituição federal no seu art. $5^{\circ}$ não se estabelece nenhuma oposição ao estabelecimento de uma indenização punitiva. Moraes corrobora com esta posição: 
Um caráter punitivo na reparação de dano moral para situações potencialmente causadoras de lesões a um grande número de pessoas, como ocorre nos direitos difusos, tanto na relação de consumo quanto no Direito Ambiental. Aqui a ratio será a função preventivo-precautória, que o caráter punitivo inegavelmente detém, em relação às dimensões do universo a ser protegido. (MORAES, 2003, p. 263).

Todavia não é sedimentada na jurisprudência, nem é consenso na doutrina a observância do critério punitivo-pedagógico no arbitramento da indenização em face dos danos sociais laborais, por haver controvérsias se o descumprimento regular da legislação laboral teria realmente impacto em toda a sociedade. Ademais, o prejuízo sofrido não deveria ultrapassar a reparação do ofensor, além da extensão do dano injusto (art. 944, CC). Neste caso, haveria uma transferência de algo excedente para o patrimônio da vítima e, por consequência um enriquecimento sem causa do ofendido.

\section{Dano social}

Parte da doutrina ainda elenca como caracterização desse dano aspectos que traduzem não apenas lesões macrossociais, mas também estratégias de atuação de certos empreendimentos econômicos e sociais lesivos a sociedade e tutelada pela constituição da república, caracterizando um exercício abusivo na execução dos negócios jurídicos. Configuram a lesividade no dumping social quanto atinge: a "dignidade da pessoa humana, ao valor social do trabalho, à segurança e bem-estar dos indivíduos, ao exercício dos direitos sociais e individuais, à ideia de uma sociedade livre, justa e solidária, a noção e realidade de justiça social” (DELGADO, 2012, p. 655) e o próprio estado democrático de direito como um todo.

A sanção do dano social não visa o ressarcimento patrimonial, sua natureza jurídica é compensatória, "impondo ao ofensor a obrigação de pagamento de uma certa quantia de dinheiro em favor do ofendido, ao mesmo tempo que agrava o patrimônio daquele, proporciona a este uma reparação satisfativa" (CAHALI, 2005, p.44). O ressarcimento ao dano não se fixa apenas na compensação da vítima pelo sofrimento, mas em uma indenização como forma de desestímulo ao agente infrator, e outros mesma situação delitiva. Neste aspecto conforme ensina José Cairo Júnior, “a responsabilidade civil está calcada basicamente na máxima neminem leadere, ou seja, o dever de não prejudicar ninguém, regra fundamental do Direito Natural." (CAIRO, 2003. p. 19). 
O dano neste caso é direcionado a coletividade, inclusive a empresas que trabalham em setores afins, que fornecem produtos a atividade principal, vítimas da concorrência desleal. Atuando não somente como desestímulo à prática de atos ilícitos, mas visando coibi-los em um futuro próximo, principalmente, porque não há como restringir direitos fundamentais a uma gama de trabalhadores específicos, pois a lesão decorrente deles atinge a setores sociais e econômicos, repercutindo em toda a sociedade.

\footnotetext{
Ora, ao se desrespeitar de forma deliberada, reiterada e institucionalizada, os direitos trabalhistas que a Constituição garante ao trabalhador brasileiro, a empresa não apenas atinge a esfera patrimonial e pessoal daquele empregado, mas também compromete a própria ordem econômica, projetada na mesma Constituição. Atua em condições de desigualdade com as demais empresas do mesmo ramo, já que explora mão de obra sem arcar com o ônus daí decorrente, praticando concorrência desleal (SOUTO MAIOR; MENDES, R.; SEVERO, V. S., 2012, p. 10).
}

Neste contexto é importante garantir um patamar mínimo civilizatório como garantidor da dignidade humana do trabalhador, impedindo a possibilidade de retrocesso social, tanto no âmbito legislativo quanto no poder judiciário, quanto de suas decisões.

\begin{abstract}
No caso brasileiro, esse patamar civilizatório mínimo está dado essencialmente, por três grupos de normas trabalhistas heterônomas: as normas constitucionais em geral (respeitadas, é claro, as ressalvas parciais expressamente feitas pela própria Constituição: art. $7^{\circ}$, VI, XIII e XIV, por exemplo); as normas de tratados e convenções internacionais vigorantes no plano interno brasileiro (referidas pelo art. $5^{\circ}, \S 2^{\circ}, \mathrm{CF} / 88$ (LGL $\backslash 1988 \backslash 3$ ), já expressando um patamar civilizatório no próprio mundo ocidental em que se integra o Brasil); as normas legais infraconstitucionais que asseguram patamares de cidadania ao indivíduo que labora (preceitos relativos à saúde e segurança no trabalho, normas concernentes à base salarial mínimas, normas de identificação profissional, dispositivos antidiscriminatórios etc.). (DELGADO, 2008, p. 1.403).
\end{abstract}

Nos casos acima expostos quanto a lesão decorrente da dignidade humana, para seu enquadramento é necessário analisar os direitos sociais e a dimensão dos direitos fundamentais a partir de um chamado mínimo social. Neste caso devemos verificar a positivação dos direitos fundamentais quanto ao déficit de proteção, no caso do Estado se abster de fiscalizar o cumprimento do mínimo adequado quanto proteção do bem jurídico a ser defendido. Como definiríamos este conteúdo essencial a ser definido?

Há uma dificuldade de se definir um mínimo laboral a ser exigido para nações com culturas diferentes, PIBs, escolaridade, todavia pode-se usar como parâmetro as oito 
Convenções Fundamentais da OIT, que tratam dos seguintes temas: (i) liberdade sindical e de negociação coletiva; (ii) combate à discriminação no emprego; (iii) proibição do trabalho infantil; e (iv) proibição do trabalho escravo. Considerados direitos fundamentais na esfera laboral, neste caso, é consenso internacional sua obrigatoriedade. Todavia, não resolve nosso problema, fora dessa lista estão muitos casos enquadrados dentro da caracterização do dumping social interno, como o desrespeito às normas de saúde e segurança, bem como o pagamento de um mínimo salarial. Digamos que este seria o núcleo duro, mas não podemos desconsiderar outros aspectos da desregulação laboral, sob pena de autorizarmos comportamentos que afetam a dignidade do trabalho, o desenvolvimento sustentável e a própria livre concorrência entre as empresas.

Parte da doutrina define em duas teorias, a teoria absoluta em que se verificaria a lesão à própria ideia de dignidade da pessoa humana e a teoria relativa em que haveria um parâmetro de proporcionalidade a ser analisado, em que se verificaria se há excessividade na restrição do direito fundamental para sua aplicabilidade. As duas teorias acabam competindo na determinação do conteúdo mínimo, que pode abarcar os direitos sociais e positivos em geral, levando a uma análise de proporcionalidade e razoabilidade, ou na concepção absoluta de um conceito abstrato de dignidade. Podem não ser excludentes, a partir da teoria absoluta exigido na esfera laboral, o cumprimento quanto a dignidade do trabalhador, proibindo o trabalho escravo, infantil e desrespeito às normas de segurança e saúde, bem como, na teoria relativa verificando o desrespeito à legislação laboral contumaz, através de uma ponderação estruturada dos efeitos sociais decorrentes. (NOVAIS, 2015, p. 69). Neste caso o próprio estado é obrigado a cumprir estas normas cogentes.

Por este motivo é que se aponta para a necessidade de todos os poderes públicos respeitarem o âmbito de proteção dos direitos fundamentais, renunciando, em regra, a ingerência, a não ser que apresente justificativa que as autoriza. Do efeito vinculante inerente ao art. $5^{\circ}, \S 1^{\circ}$, da $\mathrm{CF}$ decorre, num sentido negativo, que os direitos fundamentais não se encontram na esfera de disponibilidade dos poderes públicos, ressaltando-se, contudo, que, numa acepção positiva, os órgãos estatais se encontraram na obrigação de tudo fazer no sentido de realizar os direitos fundamentais. (SARLET, 2004, p. 327). 


\section{Considerações da atuação do poder judiciário no dumping social}

Uma das situações que há divergência doutrinária é quanto à condenação de ofício de indenização suplementar nas ações individuais quanto ao dumping social. A falta de legislação específica enseja a maioria das críticas. Parte da doutrina visando um ativismo jurídico defende a tese em cumprimento as normas constitucionais e a efetivação dos direitos fundamentais, na manutenção da paz social, impedindo comportamento antiético que prejudique através da concorrência desleal, a valorização do trabalho e a livre iniciativa, em obediência à Supremacia da Constituição e dos princípios da dignidade humana, proteção e não retrocesso social, salientando que sua permanência "representa inegável dano a sociedade, inclusive no que tange aos custos públicos para a manutenção do judiciário trabalhista que se vê obrigado a decidir dezenas e até centenas de vezes sobre as mesmas violações sobre as mesmas empresas. " (SOUTO MAIOR; MENDES, R.; SEVERO, V. S., 2012, p. 23).

Todavia não prospera tal entendimento no Tribunal Superior do Trabalho, no julgamento do processo RR - 78200-58.2009.5.04.0005, ocorrido em novembro, o relator, ministro Ives Gandra Martins Filho (foto), da Sétima Turma, reformou decisão do Tribunal Regional do Trabalho da $4^{\mathrm{a}}$ Região (RS), que havia determinado o pagamento de indenização por dumping social, mesmo não havendo pedido do trabalhador na petição inicial. O ministro em seu voto afirmou que ainda que haja previsão legal expressa na reparação dos danos patrimoniais e extrapatrimoniais causados a qualquer interesse difuso ou coletivo, o CPC determina a vinculação do juiz aos pedidos do autor. Portanto, o julgador deverá decidir a lide nos limites em que foi proposta, sendo-lhe proibido conhecer de questões não suscitadas pela parte.

O mesmo entendimento ocorre do RR - 11900- 32.2009.5.04.0291 do ministro Walmir Oliveira da Costa, relator do julgado em agosto pela $1^{\mathrm{a}}$ Turma, em que afirma que não se pode aceitar práticas abusivas de empresas que contratam mão de obra precária, desrespeitando a legislação laboral com o intuito de aumentar seus lucros. Todavia para caracterização do dumping social é necessário que siga o procedimento legal cabível, com o pedido específico de reparação na inicial da ação trabalhista, de modo que ocorra a ampla defesa e o contraditório em todas as fases processuais. Podemos ainda citar posição do TRT da 3. Região, que afasta a indenização de dumping social por falta de previsão legal. 
EMENTA: EXCESSO DE JORNADA. PENALIDADE ADMINISTRATIVA. INDENIZAÇÃO POR DUM- PING SOCIAL. FALTADE PREVISÃOLEGAL.

A extrapolação da jornada máxima permitida por lei (art. 59/CLT) configura infração administrativa, atraindo, em consequência, a competência das Delegacias Regionais do Trabalho, para a aplicação das penalidades cabíveis, não sendo crível, nesse contexto, falar-se em indenização por dumping social, por absoluta ausência de previsão legal. ${ }^{4}$

Ainda que seja majoritário na doutrina que a expressão dano prevista no art. 944 do código civil aborde um conceito amplo do termo, abrangendo não só os danos individuais, materiais ou imateriais, mas também os danos sociais, difusos, coletivos e individuais homogêneos a serem reclamados pelos legitimados para propor ações coletivas, também previsto no enunciado 456 do Conselho da Justiça Federal (AGUIAR JÚNIOR, 2012, p.66), tal não prospera quanto a falta da legitimação ativa. O STJ no julgamento da Reclamação, 12.062-GO, rel. Min. Raul Araújo, julgado em 12.11.2014, afirma: "É nula, por configurar julgamento extra petita, a decisão que condena a parte ré, de ofício, em ação individual, ao pagamento de indenização a título de danos sociais em favor de terceiro estranho

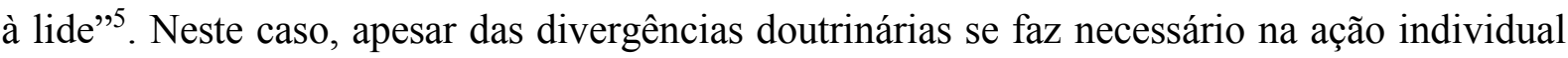
pedido específico para alcançar a indenização por dumping social.

Outro problema de aplicabilidade é quanto a reparação punitiva, de caráter pedagógico em que a lei 7.347/85, estabelece que o 'quantum' da condenação seja efetuado, através de depósito a determinados fundos com a finalidade de indenizar a sociedade como um todo. Parte da doutrina critica que a indenização do dumping social seja dirigida a entidades de direito público ou privado, tendo em vista que o empregado é que sofreu direta e individualmente o dano de ordem material e moral. Se há uma indenização suplementar a ser paga, ainda que reconhecida como dano coletivo ou social, não pode a sociedade ser reconhecida como lesionada tendo em vista a inexecução faltosa do contrato, neste caso "a violência que o produz é de direito individual homogêneo, cuja reparação é devida ao conjunto de titulares que o sofreram direta e indiretamente - e não a instituições públicas ou privadas, escolhida aleatoriamente pelo juízo, que não sofreram danos de nenhuma espécie. (PINTO, 2011, p. 148).

Entretanto, não é dominante na doutrina tal posicionamento, a obrigatoriedade legal vincula, que a indenização seja somente para os fundos estabelecidos. Neste caso, "parece imprescindível que somente se atribua caráter punitivo a hipóteses excepcionais e a hipóteses

\footnotetext{
${ }^{4}$ TRT $3^{\mathrm{a}}$ Região - Processo: 0289800-42.2009.5.03.0063 RO, $8^{\mathrm{a}}$ Turma, Relator: Paulo Roberto Sifuentes Costa, Data de Publicação: 07/06/2010.

${ }^{5}$ Direito processual civil. Impossibilidade de fixação, ex officio, de indenização por danos sociais em ação individual. Recurso repetitivo (art. 534-C do CPC (LGL\2015\1656) E Res. 8/2008 do STJ)
} 
taxativamente previstas em lei", (MORAES, 2009, p. 263-264), de modo a caracterizar que a sociedade, ainda que indiretamente, seja indenizada pelo dano social causado. Neste caso o dano extrapola o prejuízo patrimonial sofrido pelo empregado e tem natureza jurídica de lesão a sociedade como um todo, tanto ao aspecto econômico quanto social.

O dano neste caso somente pode ser reivindicado em duas situações: por meio de propositura de ação civil pública pelo Ministério Público do Trabalho ou outros legitimados constitucionalmente, utilizado na defesa de interesses difusos, coletivos e individuais homogêneos. Segue o posicionamento do TRT da 18. Região:

\section{DUMPING SOCIAL. INDENIZAÇÃO. NECESSIDADE DE REQUERIMENTO ESPECÍFICO. LEGITIMIDADE.}

Compete aos legitimados que compõem o rol previsto no artigo $5^{\circ}$ da Lei 7.347/1985, por meio da Ação Civil Pública, pleitear indenização decorrente de dumping social, dando-lhe a destinação prevista na legis- lação pertinente, pois o dano repercute socialmente, gerando prejuízos à coletividade, não podendo ser deferida de ofício, por ausência de previsão legal ${ }^{6}$

A segunda situação seria mesmo em uma ação individual a parte solicitar a indenização por dano social, presentes os pressupostos para caracterização do ilícito. O Juiz neste caso, analisando a ocorrência de conduta reiterada com indícios de concorrência desleal e um quadro geral de graves irregularidades trabalhistas, principalmente aquelas que atinjam a dignidade humana, não pode o mesmo sentenciar sem o respectivo pedido, mas deve oficiar ao Ministério Público do Trabalho, para que ele tome conhecimento e possa instaurar o inquérito para apuração dos fatos, e lavrar um termo de ajustamento de conduta ou ajuizar ação coletiva cabível, pleiteando a indenização suscitada no primeira situação abordada.

\section{Considerações finais}

O conceito de dumping social na esfera internacional se define a partir da utilização de custos salariais mais baixos, utilizando vantagens comerciais ilegítimas, com o descumprimento da legislação laboral. Consequentemente, há o risco de se reduzir o patamar mínimo civilizatório de proteção laboral para que os países desenvolvidos adequem os seus

\footnotetext{
${ }^{6}$ TRT, $18^{\mathrm{a}}$ Região. $1^{\mathrm{a}}$ Turma. Recurso Ordinário. Processo ${ }^{\mathrm{o}}$ 0001756-47.2011.5.18.0191. Desembargador Gentil Pio de Oliveira, j. em 13 jul 2012. Disponível em: http//: www.trt18.jus.br. Acesso em 11 maio 2018.
} 
custos, sem nenhuma comprovação que baixos padrões decorrentes de degradação geral dos direitos trabalhistas, realmente favoreça a competividade, tendo em vista o ganho no custo ser anulado pela baixa produtividade. No entanto, nesta ótica a liberdade comercial não pode ser o único parâmetro analisado, em uma sociedade global devem ser respeitados atitudes que valorizem a dignidade humana do trabalhador, rechaçando práticas que prejudicam o desenvolvimento econômico sustentável e a falta de reconhecimento de proteção dos mais elementares direitos laborais, o que poderia prejudicar a busca por um processo de integração social mínimo.

No ordenamento jurídico nacional o dumping social é definido pelo desrespeito da legislação laboral, sendo necessário para a sua caracterização a presença dos requisitos: conduta reiterada do não cumprimento da legislação laboral no patamar civilizatório mínimo e a concorrência desleal caracterizadora do dano social. Neste aspecto é importante comprovar a tentativa de competição injusta através do descumprimento da legislação em relação a empresas transacionais e locais, bem como se o comportamento da empresa se apresenta reiteradamente a partir do descumprimento de matérias relevantes referentes a precarização laboral. Não basta apenas a caracterização de um atraso de salário e o não pagamento de verbas laborais. Há de se observar o descumprimento de matéria que atinja o direito fundamental dos trabalhadores como: o princípio da não discriminação contra as mulheres ou menores; quanto a proteção da parcela mais hipossuficiente dos empregados, no cumprimento de cota de aprendizes e deficientes; bem como no trabalho forçado e quanto a independência sindical.

A importância da aplicabilidade do instituto sobressai de modo a evitar os chamados danos sociais que afetam a sociedade como um todo. Ainda que se observe seu impacto no âmbito individual, suas consequências no coletivo são mais relevantes, com a extrapolação dos limites socioeconômicos do ato, tendo em vista seus efeitos quanto ao lucro a partir da atividade ilícita, e vantagens concorrenciais que prejudicam o mercado como um todo.

Todavia sua importância não pode desconsiderar pressupostos processuais, ainda que parte da doutrina afirme que o juiz pode de ofício se manifestar sobre a matéria, o TST já se manifestou contrariamente, considerando julgamento 'extra petita' a ação individual que favorece terceiro estranho a lide, como é nos casos de indenização por dumping social. Nesta situação pode o juiz conhecer a matéria e enviar para o Ministério Público do Trabalho ajuizar a ação civil pública correspondente, ou a parte pedir especificadamente a indenização por dano social, neste caso podendo o juiz se posicionar na lide. Quanto o endereçamento do quantum da indenização, tem previsão legal taxativa que somente os fundos coletivos cabe tal demanda 
e não a parte individual solicitante, de modo a privilegiar o ressarcimento a sociedade e não caracterizar um enriquecimento sem causa da parte litigante.

O presente trabalho se propôs a analisar aspectos relevantes da definição do dumping social na esfera laboral e sua repercussão na sociedade. A preocupação foi delimitar seus efeitos sem desconsiderar sua importância quanto a responsabilização das empresas que reiteradamente prejudicam os trabalhadores e a sociedade em geral. Entretanto é importante delinear seus requisitos adequadamente, de maneira que não aja nenhum arbítrio por parte do judiciário, o que acarretaria um desequilíbrio na relação capital-trabalho, e, a partir daí o que poderia ser um instrumento regulador da concorrência desleal, sendo mal utilizado, acarretaria um maior custo para o consumidor, que é quem no fim acaba sendo responsável por pagar o preço final do produto.

\section{Referências bibliográficas}

AGUIAR JÚNIOR, Ruy Rosado de (Coord.). Jornadas de direito civil I, III, IV e V: enunciados aprovados. Brasília, DF: Conselho da Justiça Federal, Centro de Estudos Judiciários, 2012.

CAHALI, Yussef Said. Dano moral. São Paulo: RT, 2005.

CAIRO Junior, José. O acidente de trabalho e a responsabilidade civil do empregador. São Paulo: LTr, 2003.

DELGADO, Maurício Godinho. Curso de direito do trabalho. 7. ed. São Paulo: LTr, 2008.

FERNANDEZ, Leandro. Dumping Social. São Paulo: Saraiva, 2014.

MEDEIROS NETO, Tiago. Dano Moral Coletivo. São Paulo: LTr, 2007.

MORAES, Maria Celina Bodin de. Danos a pessoa humana: uma leitura civil-constitucional dos danos morais. Rio de Janeiro: Renovar, 2003.

MOREIRA. A. O direito laboral à venda - reflexões sobre o dumping social no capitalismo globalizado. Revista de Direito do Trabalho. vol. 169/2016. Maio - Jun / 2016.

MOREIRA V. Trabalho digno para todos: "a cláusula laboral" no comércio externo na 
União Europeia. Coimbra: Coimbra Editora, 2014.

NOVAIS, Jorge Reis. A dignidade da pessoa humana-Volume 1- Dignidade e direitos fundamentais. Almedina: Coimbra, 2015.

OLIVEIRA, Sebastião Geraldo de. Indenizações por acidente do trabalho ou doença ocupacional. 7. ed. São Paulo: LTr, 2013.

PINTO, José Augusto Rodrigues. Dumping social ou delinquência patronal na relação de emprego? Revista do Tribunal Superior do Trabalho, São Paulo, v. 77, n. 3, p. 136-153, jul./set. 2011.

ROSEDÁ, Salomão. A função social do dano moral. Florianópolis: Conceito Editorial, 2009.

SANTOS, Enoque Ribeiro dos. O dumping social nas relações de trabalho - formas de combate. Revista do Tribunal Regional do Trabalho da 10 Região. v. 43 - 2015.

SARLET, Ingo Wolfgang. A eficácia dos direitos fundamentais. 4. ed. Porto Alegre: Livraria do Advogado, 2004.

SOUTO MAIOR Jorge. O dano social e sua reparação. São Paulo, Revista LTr, 2002.

SOUTO MAIOR; MENDES, R.; SEVERO, V. S. Dumping social nas relações de trabalho. São Paulo: Ltr, 2012.

VIANA, Marco Túlio. A flexibilização pelo mundo: breves notas do XVIII Congresso Mundial de direito do trabalho e seguridade social. Revista do Tribunal Regional do Trabalho da 3. ${ }^{a}$ Região. vol. 43. n. 73. 


\title{
O TELETRABALHO SOB A NOVA ÓTICA REGULATÓRIA - DESAFIOS E ADAPTAÇÕES DA MODALIDADE INSERIDA NO MUNDO DO TRABALHO
}

\author{
Adriana de Fátima Pilatti Ferreira Campagnoli \\ Universidade Estadual de Ponta Grossa \\ Silvana Souza Netto Mandalozzo \\ Universidade Estadual de Ponta Grossa
}

\section{Resumo}

A noção clássica celetista da relação empregatícia não é mais suficiente para dar conta das vinculações trabalhistas no mundo globalizado, que se organiza em torno das tecnologias de informação, que revolucionaram o modo de relacionamento pessoal. O teletrabalho é fruto desta mudança, trazendo vantagens e desvantagens ao trabalhador. Desta forma, o presente estudo, pautando-se na pesquisa qualitativa, buscou analisar aludidas questões, à luz de um modelo normativo que as tratasse de forma precisa, tendo-se optado pelo Direito Português. A partir da análise do Código do Trabalho Português, entabularam-se proposições para o aperfeiçoamento das normas nacionais que disciplinam o teletrabalho.

Palavras chave: Globalização, Teletrabalho, Normas, Vantagens, Desvantagens.

\section{Abstract/Resumen/Résumé}

The classical notion of the employment relationship isn't enough to support these connections in the globalized world, organized around information technologies, that have revolutionized the way of personal relationship. The teleworking is a result of this, bringing advantages and disadvantages to the worker. The present study, based on the qualitative research, tried to analyze the previous questions, based on a normative model that has treated them in a more precisely way, having opted for the Portuguese law. Based on the analysis of the Portuguese Labor Code, proposals have been made for the improvement of the national norms that rules teleworking. 
Keywords/Palabras-claves/Mots-clés: Globalization, Teleworking, Rules, Benefits, Disadvantages.

\section{Introdução}

Assuntos ligados ao mundo do trabalho sempre foram discutidos e ainda continuam em alta, já que a questão está relacionada aos meios de subsistência de quem exerce algum tipo de labor.

A noção clássica de relação empregatícia, nos moldes dos artigos $2^{\circ}$ e $3^{\circ}$ da Consolidação das Leis do Trabalho (CLT), em sua redação originária, era subentendida de uma forma geral dentro dos limites de um espaço geográfico determinado pelo empregado, via de regra, inserida no âmbito empresarial. Certo é que também existiam e existem empregados que desempenham as funções externamente, ou seja, com mais mobilidade em termos espaciais, e comumente, não se sujeitavam a controle de horário.

Há tempos, novas formas de prestação de serviço vêm sendo apresentadas à sociedade, em decorrência das mudanças como o trabalho é prestado, tudo sintonizado com o entendimento capitalista, que rege as atuais relações sociais. Surgem novas facetas no desenvolvimento das atividades humanas.

Na clássica obra "O fim dos empregos" já se mencionava a existência de escritório virtual, "comprimindo o tempo e flexibilizando o espaço, a nova mágica eletrônica transformou a própria ideia de escritório, de conceito espacial para temporal". Um dos exemplos é a famosa empresa norte-americana AT\&T, onde os empregados possuem um escritório móvel, com laptop, fax, telefone celular, sendo mandados para a casa. A empresa observa nesta telecomutação a onda do futuro (RIFKIN, 1995, p. 163).

Com as novas formas de prestação de serviços, as normas jurídicas passam a ser revisitadas, adaptando-se às realidades que vão surgindo. $\mathrm{O}$ presente trabalho pretende abordar alguns aspectos da nova regulamentação do teletrabalho, no Direito Brasileiro, mas não sem antes analisar os desafios do novo mundo do trabalho, os aspectos positivos e negativos do teletrabalho e por fim, elaborando um recorte sobre ele. Ainda, serão citadas algumas questões fáticas ou legais não advindas da realidade brasileira.

O caminho trilhado no presente estudo, utilizado em Ciências Sociais, pauta-se pela pesquisa qualitativa, através do método hermenêutico-dialético, utilizando somente dados retirados de fontes bibliográficas. 
Através do presente estudo se busca uma análise crítica do novo modelo de prestação laboral fora do ambiente da empresa, tido este como uma forma irreversível de retipificação contratual da era global, trazendo elementos do Direito Comparado, que possam moldar situações controvertidas à realidade contratual.

\section{Os Desafios do Eterno Mundo Novo do Trabalho}

No cenário da sociedade moderna, o fenômeno da globalização, no qual o intercâmbio, as trocas e interações entre mercadorias, pessoas, cultura, serviços, conhecimento e informações ganham abrangência planetária, tem afetado, em grande escala, as relações sociais. Para a concretização dessa interação da sociedade e seus atores, houve a necessidade de se lançar mão de tecnologias, especialmente àquelas ligadas a informação, a comunicação e a robótica. Nesse contexto, está em curso a chamada "revolução da informação", como resultado do rápido avanço da tecnologia da informática e das telecomunicações, chamada telemática (ROCHA, 2004, p. 139) e a substituição do trabalho intelectual por computadores.

Essa redefinição histórica das formas organizacionais e, em especial da relação homem-trabalho-capital foi viabilizada pelo uso de tecnologias da informação, em especial, através de meios cada vez mais inovadores de comunicação. Atualmente, a capacidade de reunir mão de obra para projetos e tarefas específicas, em qualquer lugar, a qualquer momento, e de dispersá-la com a mesma facilidade criou a possibilidade de formação da empresa virtual como entidade funcional (CASTELLS, 2000, p. 298).

Nessa era de grandes tecnologias, surgiu uma nova economia em escala mundial, à qual se pode referir como informacional e global. Pode ser definida como informacional, porque a produtividade e a competitividade de unidades ou agentes - sejam esses em nível empresarial, regional ou em escala global - dependem basicamente de sua capacidade de gerar, processar e aplicar de forma eficiente a informação baseada em conhecimento. É também referenciada como global, pois as principais atividades produtivas, o consumo e a circulação, bem como seus componentes - assim considerados o capital, o trabalho, a matéria-prima, a administração, a informação, a tecnologia e os mercados - estão organizados em escala global, diretamente ou mediante uma rede de conexões entre agentes econômicos. Na conjugação dos dois fatores, tem-se a produtividade gerada e a concorrência feita numa rede global de interação (CASTELLS, 2000, p. 87). 
A conjugação desses fatores que fazem esse mundo organizado em torno da tecnologia da informação, revolucionou completamente o modo de relacionamento das pessoas, trazendo inúmeras transformações na sociedade, impactando diretamente no mundo do trabalho. Temse que a clássica relação de trabalho, prestada em determinado local definido pelo tomador se serviços, passa a ser modificada, como reflexo das novas necessidades do mundo capitalista globalizado e da aplicação da tecnologia disponível à produção moderna. A própria noção de tempo e lugar está se alterando, pois se torna cada vez mais comum funcionários não cumprirem um horário regular de trabalho, ou ainda, exercerem suas funções fora do ambiente da empresa, em alguns dias da semana, ou em algumas horas do dia. Há, inclusive, defensores do desaparecimento da empresa tradicional, como hoje ainda existente, dando lugar às chamadas empresas virtuais (CHAPARRO, 1996, p. 9).

Foi nesse cenário de transformações que se moldou o teletrabalho, como uma espécie de prestação laboral à distância, em local diverso ao do estabelecimento físico da empresa, utilizando-se as ferramentas da telemática, no qual há um desmonte do espaço-tempo do trabalho.

Ao se conceber teletrabalho como uma modalidade laboral fruto da revolução informacional, na qual a atividade pode ser desenvolvida na própria residência do empregado, num hotel, num outro país, ou mesmo em locais inóspitos, ou durante uma viagem de negócios, há que se considerar que, para que se configure uma relação dessa natureza, devem estar presentes dois elementos essenciais, quais sejam: a distância e o uso de meios de telecomunicação combinados com o uso da informática.

Até a promulgação da Lei n ${ }^{0}$ 13.467, de 13 de julho de 2017, a execução do teletrabalho se encontrava à margem da intervenção do legislador (BARROS, 2006, p. 322), sendo a referida modalidade laboral regulada por instrumentos normativos e decisões judiciais. Nesta seara e diante da impossibilidade do Poder Judiciário acompanhar a imensa quantidade de demandas trabalhista, aplicava-se ao caso a Súmula $n^{\circ} 428$, do Tribunal Superior do Trabalho (TST), que disciplinava a questão do sobreaviso.

A Lei $n^{0} 13.467$ de 13 de julho de 2017 enfrentou a temática, inserindo na Consolidação das Leis do Trabalho (CLT) o artigo 75-B, que conceitua o teletrabalho como toda prestação de serviços preponderantemente fora das dependências do empregador, com a utilização de tecnologias de informação e de comunicação que, por sua natureza, não se constituam como trabalho externo.

Nessa seara, despontaram questionamentos acerca dos elementos que caracterizam a relação de emprego, constantes do artigo $3^{\circ}$, da CLT e a nova figura legal. Dentre estes, se 
destaca a discussão acerca da subordinação, uma das características mais importantes da relação de emprego e, cuja presença se colocava em dúvida na modalidade de teletrabalho. Contudo, neste aspecto há que se considerar que na atualidade, o fato de não mais se ter a presença do trabalhador nos locais físicos onde está estabelecida a empresa, sob a supervisão do empregador ou seus prepostos, não impede a presença do elemento subordinação. Isso porque existem outros meios de controle do empregador, que podem ser realizados a distância, como a utilização de programas on-line de controle de tempo e rendimento da produção. Diante de tal circunstância, não se pode atestar o desaparecimento da subordinação no teletrabalho, mas sim, que a tecnologia usada, cria uma nova roupagem para este elemento configurador da relação empregatícia (WOJTECKI, BRUGINSKI, 2014, p. 64.). Essa subordinação, ou dependência hierárquica-jurídica passa a ser mitigada, com um novo sentido, ou seja, mais leve.

A pessoalidade é outra característica cuja existência é passível de discussão no teletrabalho, diante da possibilidade do empregado, em tese, se utilizar de mão de obra de terceiros e de até de seus familiares para a execução das tarefas. Porém, isso não se consubstancia como uma hipótese legal, tampouco prudente, diante das consequências possíveis, tais como a caracterização de falta grave, passível de despedida por justa causa, ante a indisciplina ou insubordinação no desempenho das respectivas funções, hipóteses previstas no artigo 482, da CLT. Embora a prestação de serviços deva ser pessoal, o ideal é que o empregador deixe bem clara, de preferência de forma escrita, a situação de que somente o contratado pode desempenhar as atividades inerentes ao contrato de trabalho, o que está em consonância com o artigo 75-E, parágrafo único, do mesmo diploma legal.

Outra questão que suscita discussão é a diferenciação do teletrabalho com o trabalho externo, previsto no artigo 62, inciso I, da CLT. Da leitura da redação do artigo 75-B, da CLT denota-se que o legislador considera como teletrabalho a prestação laboral que ocorra, preponderantemente, fora das dependências do empregador e com o uso de tecnologias de informação e de comunicação. No aludido dispositivo legal há menção de que se consubstancia a modalidade em questão, quando não se considerar o trabalho como externo.

Apesar da falta de clareza na redação do artigo 75-B, da CLT, pode-se afirmar que foi intenção do legislador excluir da modalidade teletrabalho o empregado que presta serviços externamente, quais sejam, o vendedor externo, o motorista, os ajudantes de viagem, dentre outros, que não possuem um local fixo para exercer suas atividades. Isso porque se enquadram no disposto no artigo 62, I, da CLT, sendo considerados trabalhadores externos, ainda que utilizem de equipamentos de informática como smartphones, rastreadores, laptops, etc, para sua comunicação com o empregador. Merece destaque que o artigo 75-B, da CLT define que 
estará no regime jurídico do teletrabalho quem exercer, na maior parte do tempo, suas atividades extramuros empresariais, mas, via de regra, em um local específico, sem a necessidade de se locomover para exercer suas atividades.

Nessa esteira, carece de discussão o controle de jornada e direito a pagamento de horas suplementares, no regime de teletrabalho. Com relação a esse tema, há que se considerar que o legislador incluiu o inciso III, no artigo 62, da CLT, do que se depara que se retirou o teletrabalho da proteção à jornada. Desconsiderou, pois, por completo a possibilidade de utilização de meios tecnológicos pelo empregador, que permitem controlar a localização exata do trabalhador, o horário de início e fim e as atividades desempenhadas, através da vigilância dos períodos de conexão, controle de login e logout, localização física, pausas ou ligações ininterruptas para saber o andamento dos trabalhos, dentre outros meios, o que se considera uma grave distorção.

No $\S 1^{\circ}$, do artigo 75-C houve previsão expressa de que, para que se inicie o teletrabalho é necessário mútuo acordo. Contudo, o $\S 2^{\circ}$ desse dispositivo legal permite ao empregador determinar, sem anuência do obreiro, o retorno do empregado ao ambiente empresarial. Essa previsão conflita com o princípio da inalterabilidade contratual lesiva previsto no artigo 468, da CLT, que exige bilateralidade nas alterações contratuais, bem como com o artigo $7^{\circ}$, da Constituição da República Federativa do Brasil (CRFB) que disciplina que os direitos devem visar a melhoria da condição social do trabalhador. Nessa seara, o correto seria a interpretação do aludido $\S 2^{\circ}$, do artigo 75-C, da CLT à luz do citado princípio, necessitando o mútuo consentimento das partes para o retorno do teletrabalhador ao ambiente empresarial. E este ato de retorno ao trabalho presencial restou burocratizado, com o prazo prévio de quinze dias, e o ajuste em aditivo contratual. Não sendo seguidas estas duas formalidades o ato poderá ser considerado nulo, mas não existe nenhuma sanção específica a este descumprimento de obrigação.

No que diz respeito às despesas relativas à atividade, o artigo 75-D, da CLT prevê que essas são de responsabilidade do empregador. Contudo, a redação do mencionado artigo determina que esse reembolso deverá estar previsto em contrato escrito. A crítica que se aponta para a reflexão é que, a ausência de previsão contratual de determinadas despesas poderá transferir o risco da atividade econômica, que é do empregador, para a parte hipossuficiente, contrariando a disposição expressa do artigo $2^{\circ}$, da CLT, o que também representa um problema a ser contornado.

No presente trabalho se apresentaram apenas algumas das incertezas e problemáticas geradas pela regulamentação imprecisa do teletrabalho, havendo muito ainda que se discutir a 
esse respeito. Nesse compasso, ficou claro que o legislador, ao disciplinar o teletrabalho, não normatizou questões fundamentais do contrato de emprego, deixando muitas delas para ser solucionadas pelo contrato firmado entre as partes, tais como aquelas atinentes a despesas, como acima exposto, bem como referentes a atividades a serem realizadas e inclusive a alteração para regime presencial. Disso se depreende que, na modalidade de trabalho em análise, se deixa de proteger o trabalhador enquanto hipossuficiente, contrariando o princípio fundamental do valor social do trabalho, previsto no artigo $1^{\circ}$, da CRFB, além de princípio de proteção ao hipossuficiente, que norteia o próprio Direito do Trabalho, o que também se infere como uma questão sobre a qual deverão existir ajustes.

Mesmo diante das críticas apontadas à regulamentação do teletrabalho, trata-se este de uma tendência internacional, como meio de acompanhar as mudanças ocorridas nas relações humanas. $\mathrm{O}$ processo de globalização não pode ser ignorado, enquanto fenômeno expansionista, que influencia no aparecimento de novas tecnologias e que demanda por modernização na forma de prestação laboral. Assim, o teletrabalho se mostra como uma resposta a essas transformações. Esse modelo recém normatizado no Brasil, ainda que de forma a necessitar ajustes, apresenta vantagens e desvantagens, que serão analisadas sequencialmente, como forma de se justificar as adequações legislativas a serem prepostas.

\section{Teletrabalho: Sombra e Luz}

O teletrabalho, enquanto modalidade de prestação de serviço em local distinto do estabelecimento do empregador e que utiliza equipamentos eletrônicos para seu desenvolvimento, pode ser realizado em diversos locais, fora da sede da empresa. É bastante comum que se passe na própria casa do trabalhador, o que se denomina home office, sendo que esta pode estar localizada dentro ou fora da cidade, estado ou país sede da empresa. Há também a possibilidade de se dar num centro-satélite de telesserviços, que se trata de um edifício (ou parte deste) onde o teletrabalhador irá desenvolver suas atividades laborativas, sendo este local normalmente próximo de sua residência (GOULART, 2009, p. 35-37). Diante disso, essa modalidade de prestação de serviços pode se mostrar como uma exploração ao trabalhador, mas também pode apresentar um viés vantajoso aos atores da relação laboral.

Em primeiro lugar, o fato de o trabalhador exercer as suas atribuições em local diferente da sede da empresa pode levar a seu isolamento social e profissional, prejudicando a interação com seus pares, bem como a perda da ação coletiva (PEREIRA JÚNIOR, CAETANO, 
2009, p. 2), pois haverá dificuldade da participação na defesa de direitos coletivos. Nesta seara, o trabalhador também poderá estar privado da troca, in loco, de experiências e informações, bem como da partilha e debate de ideias com os seus pares, o que possibilitará a geração de um fator de descrédito da importância do seu trabalho na estrutura organizativa em que se insere.

Além do isolamento, o teletrabalho em domicílio poderá gerar uma constante interferência entre a vida profissional e a vida familiar. Nesse sentido, o teletrabalhador está propício a permitir a invasão do tempo de trabalho no seu tempo livre, pois a flexibilidade gerada pela realização do trabalho na sua residência poderá acarretar a falta de nitidez entre os dois tempos e, consequentemente, não existir o devido desfrute num e falta de concentração no outro. E com isso existe grande chance que o teletrabalhador labore mais horas, comparado ao trabalhador do modelo tradicional, do que podem despontar consequências físicas e psicológicas (MAÑAS, 2003, p. 137).

Também, em sendo as tecnologias de informação e comunicação condições essenciais a configuração do teletrabalho, estas podem tomar lugar de um olho eletrônico, que supervisiona o trabalhador de forma permanente e, por vezes, até mesmo intrusa, gerando consequências hábeis a refletir na própria saúde mental do trabalhador (SAKO, 2014, p. 32), além de um controle de sua jornada, o que conflitaria com o disposto no artigo 62, III, da CLT.

Há, ainda, a questão das despesas com o teletrabalho, como por exemplo, a energia consumida, manutenção do sistema e possíveis visitas que o empregador ou alguém por ele designado fará à residência do teletrabalhador. Tais encargos, como já mencionado, deverão estar estabelecidos em contrato celebrado entre empregado e empregador, no qual poderão estar estabelecidos valores aquém daqueles efetivamente despendidos.

Mesmo diante das desvantagens do teletrabalho, há que se considerar que essa modalidade traz implicações benéficas, não só ao trabalhador, mas também a entidade familiar. Nesse aspecto, ao se considerar o teletrabalho realizado na residência do trabalhador, tem-se este local como mais confortável a este, pois além de ter gastos, tempo e riscos reduzidos com o deslocamento residência-trabalho-residência, pode realizar suas atividades sem abrir mão do convívio familiar, além da flexibilidade de horário.

Nesse sentido, há que se considerar que a conciliação entre a vida pessoal e profissional está presente como um dos maiores e importantes benefícios de prestar a atividade em regime de teletrabalho (COLLADOS, 2014, p. 38). Isto se pode mostrar como uma boa opção de trabalho para pessoas que têm filhos pequenos, pois permite a conjugação da vida familiar com a laboral. E tem-se a mulher como o gênero que mais tem a saúde psicológica 
afetada pelo trabalho, dada a dificuldade de aliar a vida profissional com suas responsabilidades com os filhos e com as tarefas domésticas (ROBERTS, HODGSON, 2011, p. 1070).

Isso tem especial relevância em países como o Brasil, onde são poucas as empresas que promovem condições dignas de trabalho para as mães com filhos pequenos, bem como diante da precariedade de serviços públicos, quando da oferta de creches, escolas e contraturnos onde as genitoras possam ter atenção para seus filhos enquanto exercem a atividade laborativa. Destaque-se que a CLT prevê, em seu artigo $389, I V, \S \S 1^{\circ}$ e $2^{\circ}$ a necessidade de manutenção, pelos estabelecimentos em que trabalhem mais de trinta mulheres com idade superior a dezesseis anos, de local adequado a permanência de seus filhos no período de amamentação, ou que isto seja feito por convênio com outras entidades públicas ou privadas. Tais dispositivos corroboram com o argumento das dificuldades e necessidades especiais que têm as mulheres, em especial aquelas que têm filhos, no desenvolvimento de atividades laborais.

Ainda, como contraponto a ingerência das horas de trabalho no tempo de lazer do teletrabalhador, este pode ter autonomia para delimitar e distribuir as suas horas de trabalho, em momentos de alternância com a rotina familiar. Mas para que isso não se torne uma ingerência do tempo de trabalho no seu tempo livre, há necessidade do teletrabalhador criar e organizar um ambiente apropriado e ideal na sua própria casa, exclusivo para o labor, bem como estabelecer horários e rotinas, de modo que as atividades e horários não se confundam.

Outra questão que merece relevo diz respeito à possibilidade do teletrabalhador fazer as refeições em sua própria residência, o que é bastante incomum para os trabalhadores que prestam serviços na sede da empresa, especialmente em grandes centros, nos quais há a impossibilidade de se deslocar até suas casas no intervalo intrajornada. Além de isto representar uma redução de custos, reflete na própria saúde do trabalhador.

Mesmo diante das considerações expostas, nas quais foram apontadas algumas das desvantagens e vantagens do teletrabalho, não se pode ignorar que a atual sociedade pósindustrial é marcada pela produção flexível, descentralizada e com eficaz controle à distância. Nesse sentido, o grande desafio que se impõe é a busca da retipificação dos contratos de trabalho, calcada num amplo debate que leve em conta os anseios dos interlocutores sociais, não se podendo admitir uma lei que ampare, unilateralmente, interesses dos trabalhadores ou dos empregadores. A aludida retipificação deve considerar os reais interesses das partes envolvidas, sem prejuízo de restrições previamente impostas pelo Estado, em função da tutela de valores fundamentais da sociedade (MANNRICH, 1999, p. 205).

Com isso, trata-se do teletrabalho de uma forma de retipificação contratual, irreversível. Assim, a busca é para que as arestas existentes entre os dispositivos legais que 
disciplinam a questão e a realidade que se apresenta sejam aparadas, adaptando, com isso, o Direito do Trabalho às novas características da sociedade pós-industrial, sem deformá-lo e sem tirar-lhe o espírito tutelar, peculiar e essencial (DALLEGRAVE NETO, 2014, p. 27).

Para atender a essa proposta, tem-se que o conceito legal de teletrabalho previsto no caput do artigo 75-B, da CLT, inserido por força da Lei no 13.467 de 13 de julho de 2017 se aproxima daquele constante do artigo 168, do Código do Trabalho Português ${ }^{1}$. Contudo, a legislação portuguesa preocupou-se com determinadas questões, que não foram previstas na regulamentação do teletrabalho no Brasil, as quais já foram questionadas em item anterior. Sendo assim, se passa a uma abordagem do instituto em discussão, previsto na legislação portuguesa, como paradigma para que sejam propostas sugestões hábeis a solucionar determinados impasses gerados pela maneira que foi disciplinado o instituto na legislação pátria.

\section{4. (Re)Pensando o Teletrabalho}

Quando da regulamentação legal do teletrabalho, pela Lei no 13.467 de 13 de julho de 2017, inclui-se na CLT o Capítulo II-A, que trata especificamente do tema nos artigos 75-A a 75-E. Contudo, referidos dispositivos legais deixaram in albis algumas questões, tais como a jornada de trabalho a ser desenvolvida pelo teletrabalhador. Ainda, transferiram para livre estipulação entre as partes a aquisição, manutenção ou fornecimento dos equipamentos tecnológicos e da infraestrutura necessária e adequada à prestação do trabalho remoto, bem como ao reembolso de despesas arcadas pelo empregado, além de permitir a alteração do contrato, unilateralmente, pelo empregador, previsões que necessitam de uma nova discussão para que se adequem aos princípios que regem o Direito Juslaboral.

Como forma de enfrentamento do tema, utilizar-se o Direito Comparado, especificamente a legislação portuguesa, como ferramenta de comparação e, quiçá, aperfeiçoamento do direito nacional. $\mathrm{O}$ que se pretende com tal procedimento é responder a duas questões, quais sejam: como a legislação portuguesa trata questões atinentes à jornada, despesas e alterações contratuais, no regime de teletrabalho; e se o modelo legal de referido país poderia fornecer alguma noção positiva e mais avançada sobre o tema.

\footnotetext{
${ }^{1}$ Lei n. ${ }^{\circ}$ 99, de 27 de agosto de 2003 que, pela primeira vez, codificou grande parte da legislação laboral num único diploma legal.
} 
Dessa maneira, ao se entender a hipótese como uma proposição declarada para responder a um problema, e que esta é um enunciado geral de relação entre variáveis (fatos e fenômenos) (MARCONI; LAKATOS, 2011, p. 139), o estudo parte de duas hipóteses básicas, sendo a primeira, que a legislação brasileira, ao disciplinar o teletrabalho deixou a margem questões importante, bem como contrariou princípios do Direito do Trabalho; que o modelo português foi mais específico nas mesmas temáticas, trazendo soluções mais apropriadas ao modelo do teletrabalho.

Com relação às variáveis, há que se considerar que, apesar da CLT e do Código do Trabalho português tratarem o instituto do teletrabalho de modo próximo, se distanciam quando do tratamento de jornada, despesas e alterações no contrato. Vale dizer que o sistema jurídico português foi mais preciso que o brasileiro nos tópicos em análise, conforme será demonstrado na sequência.

Quanto ao método de procedimento, utilizar-se-á da microcomparação, pois a análise será feita com institutos jurídicos ${ }^{2}$ afins em ordens jurídicas diferentes (ALMEIDA, 1994, p. 78). E a justificativa da seleção do ordenamento jurídico português foi feita em decorrência da proximidade de seus princípios e regras atinentes ao contrato individual de trabalho, com o ordenamento jurídico nacional, em especial, ao disciplinar o teletrabalho.

Nesse contexto, ao se analisar a exposição de motivos da proposta do Código do Trabalho Português de 2003, a orientação que presidiu a sua elaboração estava atenta a abertura e a introdução de novas formas de trabalho, mais adequadas às necessidades dos trabalhadores e das empresas. Com isso, o legislador assumiu a importância de ultrapassar as barreiras mais conservadoras das tradicionais relações de trabalho (ABRUNHOSA E SOUSA, 2016, p. 3), dentre as quais estava o teletrabalho.

No que diz respeito às hipóteses propostas, partindo da questão atinente à jornada, no Código do Trabalho Português, as alíneas c e d, do item 5, do artigo $166^{3}$, preveem as necessidades de indicação no contrato do período normal de trabalho, bem como eventuais atividades a serem exercidas após dito lapso temporal, se este for menor que a duração do trabalho prevista na lei. Também estão dispostas no artigo $170^{4}$ do mesmo código, questões

\footnotetext{
${ }^{2}$ Instituto jurídico é o conjunto de normas, princípios e instituições de natureza jurídica que, numa dada ordem jurídica, possam ser tomados unitariamente sob certa perspectiva ou critério (ALMEIDA, 1994, p. 9).

${ }^{3}$ Artigo $166 .^{\circ}$ Regime de contrato para prestação subordinada de teletrabalho [...] 5 - O contrato está sujeito a forma escrita e deve conter: [...] c) Indicação do período normal de trabalho; d) Se o período previsto para a prestação de trabalho em regime de teletrabalho for inferior à duração previsível do contrato de trabalho, a atividade a exercer após o termo daquele período; [...].

${ }^{4}$ Artigo $170 .{ }^{\circ}$ Privacidade de trabalhador em regime de teletrabalho 1 - O empregador deve respeitar a privacidade do trabalhador e os tempos de descanso e de repouso da família deste, bem como proporcionar-lhe boas condições de trabalho, tanto do ponto de vista físico como psíquico. 2 - Sempre que o teletrabalho seja realizado no domicílio
} 
relativas à privacidade do trabalhador em regime de teletrabalho, sendo dever do empregador respeitar tal direito e os tempos de descanso e de repouso da família, além de proporcionar-lhe boas condições de trabalho, tanto do ponto de vista físico como psíquico. Neste dispositivo legal há, inclusive, menção expressa do horário que o empregador (ou seu preposto) pode visitar o local onde está sendo realizado o teletrabalho, ficando este estipulado entre às nove e às dezenove horas e sempre com a assistência do trabalhador ou de pessoa por ele designada.

Ao se analisar as normas mencionadas e ao se considerar que o teletrabalho normalmente é desenvolvido no domicílio do trabalhador, tem-se que a indicação do período normal de trabalho se torna um fator importante. Isso porque, existem diversas tecnologias ao dispor do empregador para que controle o tempo de trabalho de seus empregados, bem como que, pela peculiaridade do local de prestação de serviços, a fronteira entre tempo de trabalho e descanso pode ser muito tênue (ABRUNHOSA E SOUSA, 2016, p. 9). E mesmo diante da dificuldade de controle do efetivo tempo de trabalho do teletrabalhador, este pode ser feito através da utilização de instrumentos que permitem a vigilância do acesso aos instrumentos de trabalho.

Diante disso, mister se faz que haja uma alteração do disposto no artigo 62, da CLT, em especial do inciso III, que exclui o teletrabalhador do direito a fixação de jornada e, por consequência do pagamento de horas extras. O que se prega é a previsão da obrigatoriedade de ser estipulado no contrato celebrado entre o empregador e o teletrabalhador, a duração do trabalho, assim como os períodos em que deverá ficar a disposição do empregador para atender as suas ordens, além do horário em que se possa viabilizar eventuais visitas deste ao local de trabalho. Não se vislumbra a obrigatoriedade de estipular uma jornada específica, mas o número de horas que o empregado estará à disposição do empregador durante certo lapso temporal. Com isso, sempre que as tarefas exigirem tempo maior para execução, o obreiro terá direito ao pagamento de horas extras, bem como para que possa conjugar períodos de trabalho e descanso, sem ser importunado neste com cobranças de ordem laboral.

Com relação à segunda hipótese, ao disciplinar o teletrabalho, o legislador brasileiro possibilitou a alteração unilateral do contrato de emprego que tenha sido realizado nessa modalidade, para a presencial, conforme se depreende da análise do $\S 2^{\circ}$, do artigo $75-\mathrm{C}$, da CLT. Contudo, se trata de alteração contratual lesiva, que contraria o expressamente disposto no artigo 468, da CLT. Quanto a este aspecto, o Código do Trabalho Português dispõe, no item

\footnotetext{
do trabalhador, a visita ao local de trabalho só deve ter por objeto o controlo da atividade laboral, bem como dos instrumentos de trabalho e apenas pode ser efetuada entre as 9 e as 19 horas, com a assistência do trabalhador ou de pessoa por ele designada. 3 - Constitui contraordenação grave a violação do disposto neste artigo.
} 
6, do artigo $166^{5}$ que, para que o trabalhador em regime de teletrabalho passe a trabalhar no regime presencial, seja isto em caráter temporário ou definitivo, há necessidade de acordo escrito entre as partes.

Destaque-se que a importância da tutela ao trabalhador decorre da posição de hipossuficiência desde diante do tomador de serviços, pois não tem a mesma possibilidade de dirigir a contratação, opinar sobre as cláusulas contratuais, ou mesmo questionar alguma delas, sob pena da possível perda do vínculo laboral, o que afeta diretamente a sua liberdade de consentimento (GOMES, GOTTSCHALK, 2006, p. 323). Por isso, torna-se de fundamental essa proteção jurídica ao trabalhador nas relações laborais, estando aí incluído o teletrabalho, carecendo de revisão a normativa brasileira, para se proibir a alteração unilateral do contrato.

Já no que diz respeito à aquisição de equipamentos e reembolso de despesas, o legislador brasileiro deixou a pactuação a encargo das partes. Diverso disso, o Código do Trabalho Português, no artigo $168^{6}$, coloca como regra a presunção do fornecimento e manutenção das tecnologias de informação e de comunicação utilizados pelo trabalhador. Estabelece ainda, a obrigação do empregado na observância das regras de utilização e funcionamento dos instrumentos de trabalho que lhe forem disponibilizados, inclusive vedando para uso diverso, salvo estipulação em contrário.

Isto demonstra a necessidade de se identificar a propriedade dos instrumentos de trabalho e, mais além, a instalação e manutenção dos referidos materiais, além do pagamento das respectivas despesas, o que se apresenta como um fator relevante que sublinha a natureza laboral do teletrabalho.

Também, a transferência do ônus da aquisição e manutenção de equipamentos pelo empregado, o que pode se tornar facilmente a regra no Direito Brasileiro, diante da previsão de que tal matéria deverá estar expressamente prevista no contrato, entregaria o risco da atividade econômica para o empregado, em contrário ao expressamente disposto no artigo $2^{\circ}$, da CLT. Trata-se da alteridade, que se traduz na ideia de responsabilização do empregador pelos custos e resultados do trabalho prestado, além da responsabilização pela sorte de seu próprio

\footnotetext{
${ }^{5}$ Artigo $166 .^{\circ}$ Regime de contrato para prestação subordinada de teletrabalho [...]6 - O trabalhador em regime de teletrabalho pode passar a trabalhar no regime dos demais trabalhadores da empresa, a título definitivo ou por período determinado, mediante acordo escrito com o empregador. [...]

${ }^{6}$ Artigo $168 .{ }^{\circ}$ Instrumentos de trabalho em prestação subordinada de teletrabalho 1 - Na falta de estipulação no contrato, presume-se que os instrumentos de trabalho respeitantes a tecnologias de informação e de comunicação utilizados pelo trabalhador pertencem ao empregador, que deve assegurar as respetivas instalação e manutenção e o pagamento das inerentes despesas. 2 - $\mathrm{O}$ trabalhador deve observar as regras de utilização e funcionamento dos instrumentos de trabalho que lhe forem disponibilizados. 3 - Salvo acordo em contrário, o trabalhador não pode dar aos instrumentos de trabalho disponibilizados pelo empregador uso diverso do inerente ao cumprimento da sua prestação de trabalho.
} 
empreendimento (DELGADO, 2009, p. 375). Assim, na hipótese em discussão, a transferência dos custos de aquisição, ou mesmo manutenção dos equipamentos ao teletrabalhador, estar-seia contrariamente expressa disposição legal. Diante disso, há necessidade de adequação da legislação pátria, a fim de que a hipótese em discussão só possa ser adotada por exceção e mediante benesse contraprestativa concedida ao hipossuficiente.

Para evitar a sensação de isolamento do trabalhador e o trauma psicológico que isto pode causar, empresas como Olivetti Research Laboratory, na Inglaterra, permitem experiências em computadores, permitindo que até cinco pessoas conversem e laborem juntas, através de versão eletrônica de comunicação pessoal (RIFKIN, 1995, p. 164). Outra sugestão pode ser a existência de reuniões presenciais, quando possível, mormente para que o teletrabalhador se sinta inserido dentro da organização empresarial ao lado de outros empregados, resgatando ainda que de forma precária o sentimento de união.

O bem-estar físico e mental do empregado inserido na condição de teletrabalho é questão a ser repensada pelas partes envolvidas. Cuidados para o trabalho não se tornar monótono, cansativo e não saudável é um dos desafios para a modalidade.

Quanto à alteração contratual prevista no $\S 2^{\circ}$, do artigo 75-C, da CLT, conforme já elencado, se trata de medida lesiva, vedada pelo artigo 468, da CLT. Nesse compasso, mister se faz que se adapte a legislação pátria, a fim de que somente se permita dita alteração com o consentimento do trabalhador e se isto, efetivamente, se consubstanciar num benefício ao hipossuficiente, utilizando-se como paradigma o disposto no item 6, do artigo 166, do Código do Trabalho Português. ${ }^{7}$

Diante do exposto, tem-se que a previsão normativa do teletrabalho no Direito Português apresenta semelhança com os dispositivos inseridos na CLT, pela Lei $n^{\circ} 13.467$, de 13 de julho de 2017. Contudo, o que se denota é que o legislador lusitano foi mais preciso, com relação à previsão de matérias que ensejam muitas discussões no contrato de emprego, inclusive na modalidade presencial, como é o caso da duração do trabalho, bem como de questões atinentes ao risco da atividade e alterações contratuais, privacidade e a própria personalidade do empregado. Desta forma, é justificável a necessidade de revisão nas normas que disciplinam essa modalidade de trabalho, a fim de que primem pela efetivação dos princípios do Direito do Trabalho, bem como não transfiram ao Poder Judiciário a responsabilidade de solucionar esses

\footnotetext{
${ }^{7}$ Artigo $166 .{ }^{\circ}$ Regime de contrato para prestação subordinada de teletrabalho [...] 6- Poderá ser realizada a alteração do regime de teletrabalho para o presencial por determinação do empregador, garantido prazo de transição mínimo de quinze dias, com correspondente registro em aditivo contratual. [...].
} 
impasses, através da edição de Súmulas, pois até que isso se consolide, muitos direitos terão sido violados.

\section{Conclusão}

A descentralização produtiva e organizativa no mercado global, aliada aos avanços das tecnologias e a proliferação de recursos informáticos e telemáticos compeliram a uma reestruturação das formas organizacionais do trabalho e dos processos produtivos, com o aparecimento de novos modelos contratuais. Nesta teia de tecnologia globalizante despontou o teletrabalho, uma nova forma de trabalhar e, essencialmente, uma nova forma de existir.

O novo modelo de contrato está calcado em duas características: a prestação laboral à distância, fora dos limites da empresa e o uso de tecnologias de informação e de comunicação. A fórmula mais frequente é o teletrabalho no domicílio do empregado. Esta modalidade suscitou dúvidas com relação à presença dos elementos caracterizadores da relação de emprego, previstos no artigo $3^{\circ}$ da CLT.

Através do estudo realizado, verificou-se a presença da subordinação, através do controle à distância feito pelo empregador, utilizando-se das próprias tecnologias indispensáveis ao teletrabalho. Quanto à pessoalidade, é cuidado a ser tomado pelo tomador de serviços a estipulação contratual de quem está habilitado a prestação laboral, sob pena de aplicação de penalidade, como a despedida por justa causa.

Os problemas começaram a surgir quando se enfrentou a temática alusiva à duração do trabalho e o ressarcimento de despesas. Isto porque a legislação pátria não deu o devido tratamento a tais assuntos, pois excluiu o direito ao pagamento de horas extras para o teletrabalhador, bem como determinou que o ressarcimento de despesas decorresse de estipulação contratual, transferindo o risco da atividade para o trabalhador. Foram questões levantadas e para as quais se buscou alternativa no Direito Comparado, como ferramenta de aperfeiçoamento do Direito Nacional.

Através da análise e comparação das normas trabalhistas brasileiras e portuguesas, com relação ao teletrabalho, foi possível não só encontrar os seus pontos comuns e evidenciar as suas particularidades, como, também, captar as características próprias do tratamento dado a tal modalidade pelo Direito Lusitano, a fim de ser utilizado como paradigma ao Direito Pátrio, favorecendo a criação de bases mais sólidas para a fundamentação do estudo. 
Nesta seara, foram evidenciadas as necessidade de alterações legislativas, no tocante a estipulação da duração do trabalho e horários de visita ao local de prestação de serviços, pelo empregador, ou seu preposto. Tal medida impactaria na possibilidade de conciliação entre a vida pessoal e profissional, pontos que refletem nos níveis de satisfação profissional do trabalhador, além do respeito a seu direito a privacidade. Isso porque, a facilidade de comunicação proporcionada pelas tecnologias podem permitir que os teletrabalhadores estejam permanentemente acessíveis, não se diferenciando, da forma devida, o tempo de trabalho e o tempo de descanso.

Já com relação às despesas decorrentes do teletrabalho, defendeu-se a necessidade de se abandonar o prescrito no artigo 75-D, da CLT, que se consubstancia na transferência dos riscos da atividade econômica para o hipossuficiente. Foi apontada a necessidade de se colocar como regra a presunção do fornecimento e manutenção das tecnologias de informação e de comunicação pelo empregador, conforme moldado no Direito Laboral Português. Na mesma esteira seguiu a alteração unilateral da forma de contratação na modalidade de teletrabalho para presencial, de modo que se siga o modelo lusitano de acordo entre as partes e, desde que este gere benefício ao hipossuficiente.

Diante do analisado, denotou-se maior precisão na forma de tratamento que o Código do Trabalho Português deu ao teletrabalho, em comparação com a norma brasileira, disciplinando expressamente determinadas questões, alvos de muita discussão nos contratos de emprego, como a duração do trabalho, despesas com a atividade e a possibilidade de alteração contratual. Neste aspecto, disciplinou em favor do trabalhador, indo ao encontro do princípio protetivo, norteador do Direito Laboral.

O teletrabalho representa uma nova modalidade de contratação laboral, que apresenta desvantagens e vantagens. Contudo, trata-se de uma forma irreversível e necessária a adaptação do Direito do Trabalho às novas características da sociedade pós-industrial. Muito se tem discutido e há muito que se falar a respeito desse instituto, mas somente o tempo irá demonstrar se este modelo trará mais benefícios ou malefícios ao trabalhador e ao empregador.

\section{Referências bibliográficas}

ABRUNHOSA E SOUSA, D. O enquadramento legal do teletrabalho em Portugal. Revista Derecho Social y Empresa, n. 6, p. 1-7, dec./2016. Disponível em:<http://www.ajj.pt/ publicacoes/3>. Acesso em 5 mai. 2018. 
ALMEIDA, C. F. de; CARVALHO, J. M. Introdução do Direito Comparado. Portugal: Almedina, 1994.

BARROS, A. M. Curso de Direito do Trabalho. 2. ed. São Paulo: LTr, 2006.

CASTELLS, M. A sociedade em rede: a era da informação: economia, sociedade e cultura. v. 1. São Paulo: Paz e Terra, 2000.

CHAPARRO, F. O. El teletrabajo: Uma nueva sociedad laboral en la era de la tecnología. Madrid: McGraw-hill, 1996.

COLLADOS, M. B. F. Negociación sobre la adaptación de la jornada por razones personales o familiares. Nueva Revista Española de Derecho del Trabajo. n. 168, 2014. Disponível em: $<$ https://dialnet.unirioja.es/servlet/articulo?codigo=4900670>. Acesso em: 1 mai. 2018.

DALLEGRAVE NETO, J. A. O teletrabalho: importância, conceito e implicações jurídicas. Revista Tribunal Regional do Trabalho da $9^{a}$. Região, Curitiba, v. 33, n. 33, p. 08-27, set. 2014. Disponível em:

$<$ https://ead.trt9.jus.br/moodle/pluginfile.php/24246/mod_resource/content/1/Revista\%20Elet r\%C3\%B4nica\%20\%28SET\%202014\%20-\%20n\%C2\%BA\%2033\%20\%20Teletrabalho\%29.pdf> Acesso em: 5 mai. 2018.

DELGADO, Maurício Godinho. Curso de Direito do Trabalho. 8. ed. São Paulo: LTr, 2009.

FINCATO, D. P. Teletrabalho: uma análise juslaboral. In: STÜRMER, G. (Org.). Questões controvertidas de Direito do Trabalho e outros estudos. Porto Alegre: Livraria do Advogado, 2006.

GOMES, O. GOTTSCHALK, E. Curso de Direito do Trabalho. 17. ed. Rio de Janeiro: Forense, 2006.

GOULART, J. O. Teletrabalho: alternativa de trabalho flexível. Brasília: Senac, 2009. 
MAÑAS, C. M. A Externalização da Atividade Produtiva: o Impacto do Teletrabalho na Nova Ordem Socioeconómica. Revista da Faculdade de Direito da Universidade Federal do Paraná, Curitiba, v. 39, 2003. Disponível em: $<$ https://revistas.ufpr.br/direito/article/view/1750>. Acesso em: 6 mai. 2018.

MANNRICH, N. A retipificação do contrato de trabalho. In: NASCIMENTO, A. M. (Coord). A transição do Direito do Trabalho no Brasil. São Paulo: LTr, 1999.

MARCONI, M. A.; LAKATOS, E. M. Fundamentos de metodologia científica. 6. ed. São Paulo: Atlas, 2005.

PEREIRA JUNIOR, E.; CAETANO, M. E. S. Implicações do teletrabalho: um estudo sobre a percepção dos trabalhadores de uma região metropolitana. Revista Psicologia, Organizações e Trabalho, Florianópolis, v.9., n.2, dez. 2009. Disponível em: <http://pepsic.bvsalud.org/ scielo.php?script=sci_arttext\&pid=S1984-66572009000200003>. Acesso em: 3 mai. 2018.

RIFKIN, J. O fim dos empregos. São Paulo: Makron Books, 1995.

ROBERTS, J.; HODGSON, R.; DOLAN, P. It's driving her mad: Gender differences in the effect of commuting on psychological health. Journal of Health Economics, n. 30 p. 10641076, 2011. Disponível em:

$<$ https://www.sciencedirect.com/science/article/abs/pii/S0167629611000853>. Acesso em: 5 mai. 2018.

ROCHA, M. O. Direito do Trabalho e Internet. São Paulo: Livraria e Editora Universitária de Direito, 2004.

SAKO, E. S. A. Teletrabalho telesubordinado, dependente e por conta alheia: reengenharia dos requisitos da relação empregatícia Revista Tribunal Regional do Trabalho da $9^{\mathbf{a}}$. Região, v. 33, n. 33, p. 28-45, set. 2014. Disponível em: <https://ead.trt9.jus.br/moodle/ pluginfile.php/24246/mod_resource/content $/ 1 /$ Revista $\% 20$ Eletr $\%$ C3\%B4nica $\% 20 \% 28$ SET $\%$ 202014\%20-\%20n\%C2\%BA\%2033\%20-\%20Teletrabalho\%29.pdf> Acesso em: 5 mai. 2018. 
WOJTECKI, C. M. R.; BRUGINSKI, M. K. A redefinição da subordinação jurídica no teletrabalho. Revista Tribunal Regional do Trabalho da 9'. Região, Curtiba, v. 33, n. 33, p. 58-70, set. 2014. Disponível em: < https://ead.trt9.jus.br/moodle/pluginfile.php/ 24246/mod_resource/content/1/Revista\%20Eletr\%C3\%B4nica\%20\%28SET\%202014\%20\%20n\%C2\%BA\%2033\%20-\%20Teletrabalho\%29.pdf> Acesso em: 5 mai. 2018. 


\title{
REPENSANDO O CONCEITO \\ DO TRABALHO ESCRAVO CONTEMPORÂNEO \\ PARA A SUA ERRADICAÇÃO NA REALIDADE LABORAL BRASILEIRA
}

\author{
Luciana Aboim Machado Gonçalves da Silva \\ Universidade Federal de Sergipe \\ Christiane Rabelo Britto \\ Universidade Federal de Sergipe
}

\section{Resumo}

Esse trabalho científico tece uma análise da significação do trabalho escravo contemporâneo com vistas a normatização brasileira e a previsão em tratados internacionais de direitos humanos, a fim de averiguar em que medida a pluralidade de termos utilizados interfere no combate efetivo da escravidão moderna. Nessa perspectiva, apresenta uma conceituação do trabalho escravo contemporâneo através da dogmática jurídica e da análise interpretativa e sistemática das normas jurídicas, para estabelecer a desnecessidade de uma conceituação expressa do trabalho escravo contemporâneo, tendo em vista que esses mecanismos nos leva a melhor conceituação da conduta exploradora do trabalho humano, para englobar tanto o cerceamento da liberdade de locomoção quanto à proteção da dignidade humana.

Palavras-chave: trabalho escravo contemporâneo, essência normativa, dogmática jurídica, dignidade da pessoa humana, precarização do trabalho

\footnotetext{
Abstract/Resumen/Résumé

This scientific work has an analysis of the meaning of contemporary slave labor with a Brazilian normalization and the human rights treaties forecast, with the purpose of ascertain to what extent the plurality of terms interferes in the effective modern slavery combat. In this perspective, it presents the contemporary slave labor conceptualization of through legal language and the interpretative and systematic analysis of legal norms, to establish the lack of a slave labor explicit conceptualization, considering that these mechanisms lead us to a better exploitative conduct of human labor, to encompass both the restriction of freedom and the human dignity protection.
} 
Keywords/Palabras-claves/Mots-clés: contemporary slave labor, normative essence, legal dogma, human person's dignity, work precariousness

\section{Introdução}

O presente artigo apresenta uma análise dos termos empregados na definição do trabalho escravo contemporâneo em diplomas normativos pátrios e em tratados internacionais de direitos humanos, sendo uníssona a perspectiva de que se trata de uma conduta que submete o ser humano ao tratamento vil e degradante.

Parte-se da premissa de que a ausência de elementos objetivos para auferir a significação do trabalho escravo contemporâneo dificulta sobremaneira a sua efetivação posto que contribui para atuações divergentes dos agentes que se dedicam ao combate deste ilícito, trazendo entraves na sua identificação, tendo em vista a subjetividade empregadas pelos intérpretes que aplicam as normas jurídicas.

Por conseguinte, diante da preponderância de utilização de expressões vagas para descrever a conduta de sujeição de uma pessoa a condição análoga a de escravo surgem os seguintes questionamentos: A existência de cláusulas gerais de forma preponderante na definição jurídica de escravidão contemporâneo interfere no seu combate efetivo? Existe a real necessidade de se proceder à descrição de elementos objetivos na definição do trabalho escravo contemporâneo para a unificação da atuação dos agentes responsáveis pelo seu enfrentamento? Qual seria a melhor definição para o trabalho escravo contemporâneo?

Vislumbra-se, então, que esse assunto assume destaque e vem sendo alvo de sérios questionamentos pelos que militam no combate ao trabalho escravo, inclusive há projetos de lei que visam alterar o teor do artigo 149 do Código Penal Brasileiro, que traz a definição deste ilícito, para reduzir o alcance da conceituação do trabalho escravo contemporâneo, limitando a sua configuração a práticas que cerceiam a liberdade de locomoção do indivíduo, o que provoca um retrocesso social e violação na proteção da dignidade da pessoa humana.

O desenvolvimento deste texto científico é fruto de discussões oriundas e fomentadas no Grupo de Pesquisa cadastrado no CNPq como "Eficácia dos Direitos Fundamentais: seus reflexos nas relações sociais", utilizando-se o método teórico-bibliográfico, para que sejam traçados caminhos efetivos para erradicação do trabalho em condições análogas a de escravo e a promoção do trabalho digno. 


\section{O tratamento teórico-normativo do trabalho escravo contemporâneo nos tratados internacionais de direitos humanos e na ordem jurídica brasileira}

Em atenção a normatização em âmbito internacional que contemplam a temática trabalho escravo, tem-se a Convenção sobre a Escravatura/1926, considerada o primeiro instrumento de proteção a favor da erradicação do trabalho escravo, a qual foi emendada pelo Protocolo Suplementar em 1953. Em 1956, surge a Convenção Suplementar sobre a Abolição da Escravatura, destinada a intensificar os esforços nacionais e internacionais, que visam abolir a escravidão, o tráfego de escravos e as práticas análogas à escravidão. Ambos os instrumentos foram promulgados pelo Decreto $\mathrm{n}^{\circ} 58.563 / 1966$. Tal convenção utiliza a próprio termo escravidão para se referir ao ato de sujeição de uma pessoa sobre outra quando apresenta a definição do que venha a ser trabalho escravo. ${ }^{1}$

A Convenção $n^{0}$ 29/1930 da Organização Internacional do Trabalho (OIT), denominada Convenção sobre Trabalho Forçado, trata da erradicação do trabalho forçado ou obrigatório e foi promulgada pelo Decreto $n^{\circ} 41.721 / 1957$. Apresenta a definição de trabalho forçado ao mencionar ser o trabalho exigido de uma pessoa sob ameaça de punição ou aquele com a ausência de voluntariedade ${ }^{2}$.

Já a Convenção $n^{\circ} 105 / 1957$, promulgada pelo Decreto $n^{\circ} 58.822 / 1966$, intitulada Convenção sobre a Abolição do Trabalho Forçado, coíbe o trabalho forçado ou obrigatório como forma de coerção ou de educação política; como forma de disciplina no trabalho; como castigo devido à participação em greve, como discriminação. Referencia-se ao trabalho escravo com a utilização dos termos trabalho forçado ou obrigatório ${ }^{3}$.

\footnotetext{
${ }^{1}$ Artigo $7^{\circ}$ Para os fins da presente Convenção: §1. "Escravidão", tal como foi definida na Convenção sobre a Escravidão de 1926, é o estado ou a condição de um indivíduo sobre o qual se exercem todos ou parte dos poderes atribuídos ao direito de propriedade, e "escravo" é o indivíduo em tal estado ou condição. §2. "Pessoa de condição servil" é a que se encontra no estado ou condição que resulta de alguma das instituições ou práticas mencionadas no artigo primeiro da presente Convenção. §3. "Tráfico de escravos" significa e compreende todo ato de captura, aquisição ou cessão de uma pessoa com a intenção de escravizá-la; todo ato de aquisição de um escravo para vendê-lo ou trocá-lo; todo ato de cessão, por venda ou troca, de uma pessoa adquirida para ser vendida ou trocada, assim como, em geral, todo ato de comércio ou transporte de escravos, seja qual for o meio de transporte empregado.

${ }^{2}$ Art. 2.1 Para os fins da presente convenção, a expressão 'trabalho forçado ou obrigatório' designará todo trabalho ou serviço exigido de um indivíduo sob ameaça de qualquer penalidade e para o qual ele não se ofereceu de espontânea vontade.

${ }^{3}$ Art. 1 Qualquer Membro da Organização Internacional do Trabalho que ratifique a presente convenção se compromete a suprimir o trabalho forçado ou obrigatório, e a não recorrer ao mesmo sob forma alguma: a) como medida de coerção, ou de educação política ou como sanção dirigida a pessoas que tenham ou exprimam certas opiniões políticas, ou manifestem sua oposição ideológica à ordem política, social ou econômica estabelecida; b) como método de mobilização e de utilização da mão-de-obra para fins de desenvolvimento econômico; c) como medida de disciplina de trabalho; d) como punição por participação em greves; e) como medida de discriminação racial, social, nacional ou religiosa.
} 
A Declaração Universal de Direitos Humanos/1948 (DUDH) estabelece a proibição do trabalho escravo nos artigos $4^{\circ}$ e $5^{\circ}$, no sentido de ser inadmissível a escravidão, a servidão, como também o tráfico de escravos, a tortura e o tratamento cruel, desumano e degradante 4 . Não apresenta uma definição para o trabalho escravo, apenas refere-se à proibição da escravidão e tráfico de pessoas.

A Convenção Americana sobre Direitos Humanos (Pacto de San José da Costa Rica de 1969), promulgado pelo Decreto 678/1992, protege a integridade física em seu art. 5 e proíbe a escravidão e servidão no art. 6. Apesar de não apresentar uma definição expressa do trabalho escravo, a mesma pode ser extraída do art.6, incisos 1 e 2 , como sendo o trabalho executado que afete a dignidade, bem como a capacidade física e intelectual do trabalhador. ${ }^{5}$

Da análise das normatizações colacionadas acima, percebe-se uma variedade de termos empregados para se referir ao trabalho escravo, quais sejam: escravidão, trabalho forçado ou obrigatório, servidão, sendo empregados, precipuamente, no sentido de restringir a liberdade de locomoção ${ }^{6}$.

Importante destacar que com a edição da Declaração Universal de Direitos humanos, incorporou-se ao cerceamento da liberdade, a proteção da dignidade humana, que pode ser depreendido do preâmbulo ao reconhecer a dignidade como um valor inerente a todo ser humano e a proteção dos direitos humanos em detrimento ao império das leis ${ }^{7}$.

Nesse diapasão, a Convenção Americana sobre Direitos Humanos estabelece que o trabalho forçado ou obrigatório não pode violar a dignidade do indivíduo ${ }^{8}$.

\footnotetext{
${ }^{4}$ Artigo IV Ninguém será mantido em escravidão ou servidão; a escravidão e o tráfico de escravos serão proibidos em todas as suas formas; Artigo IV Ninguém será mantido em escravidão ou servidão; a escravidão e o tráfico de escravos serão proibidos em todas as suas formas

${ }^{5}$ Art. 6.1. Ninguém pode ser submetido a escravidão ou a servidão, e tanto estas como o tráfico de escravos e o tráfico de mulheres são proibidos em todas as suas formas. 2. Ninguém deve ser constrangido a executar trabalho forçado ou obrigatório. Nos países em que se prescreve, para certos delitos, pena privativa da liberdade acompanhada de trabalhos forçados, esta disposição não pode ser interpretada no sentido de que proíbe o cumprimento da dita pena, imposta por juiz ou tribunal competente. $\mathrm{O}$ trabalho forçado não deve afetar a dignidade nem a capacidade física e intelectual do recluso.

${ }^{6}$ Para fins de terminologia adotada por esta pesquisa, utilizar-se-á os termos escravidão contemporânea, escravidão moderna e redução da pessoa a condição análoga à de escravo como sinônimos, a corresponder tanto o cerceamento da liberdade como à afronta a dignidade humana.

${ }^{7}$ Preâmbulo. Considerando que o reconhecimento da dignidade inerente a todos os membros da família humana e de seus direitos iguais e inalienáveis é o fundamento da liberdade, da justiça e da paz no mundo, Considerando que o desprezo e o desrespeito pelos direitos humanos resultaram em atos bárbaros que ultrajaram a consciência da Humanidade e que o advento de um mundo em que os todos gozem de liberdade de palavra, de crença e da liberdade de viverem a salvo do temor e da necessidade foi proclamado como a mais alta aspiração do ser humano comum, Considerando ser essencial que os direitos humanos sejam protegidos pelo império da lei, para que o ser humano não seja compelido, como último recurso, à rebelião contra a tirania e a opressão.

${ }^{8}$ Art. 6.2 Ninguém deve ser constrangido a executar trabalho forçado ou obrigatório. Nos países em que se prescreve, para certos delitos, pena privativa da liberdade acompanhada de trabalhos forçados, esta disposição não pode ser interpretada no sentido de que proíbe o cumprimento da dita pena, imposta por juiz ou tribunal competente. O trabalho forçado não deve afetar a dignidade nem a capacidade física e intelectual do recluso.
} 
A infinidade de termos utilizados para referenciar a prática escravocrata convergem para o fato de que essa conduta aniquila a dignidade humana e transmuta a pessoa em objeto. Esse fato é reforçado com o posicionamento de Rina Gómes (2001), ao afirmar que:

Así la esclavitud no es una categoría fija para todo tiempo y lugar, assume formas y representaciones muy distintas de un lugar a otro, con una especificidad histórica, temporal y espacial, donde los individuos son trabajadores forzados en una sociedad concreta y traduce, o pone en evidencia, una forma de dominación, de control y uso de poder. La esclavitud es una forma de explotacíon que la distingue de otras formas por la dualidad de los sujetos sociales: son personas y son mercancias, y como personas son propriedad. (GÓMEZ, 2001, p.33).

(2013):

Nesse contexto, é importante trazer à baila, também, as lições de Vanessa Rodríguez

\begin{abstract}
Resulta necesario recordar que es el status o condición de una persona sobre la cual se ejerce todo o alguno de los poderes associados al derecho de propriedade; y la servidumbre es la sujecíon de una persona bajo la autoridad de otra con subordinación a la voluntad y los designios de otra sin que tenga opción a decidir, protestar o discrepar, con la total perdida de la libertad y con la consecuente despersonalización y captación de voluntad. (RODRÍGUEZ, 2013, p. 82).
\end{abstract}

De acordo com o ordenamento jurídico pátrio, tem-se o art. $5^{\circ}$, incisos III e XLVII da Constituição Federal que veda o tratamento desumano ou degradante e estabelece a proibição de trabalhos forçados 9 .

O Código Penal Brasileiro reprime o crime de redução da pessoa à condição análoga à de escravo no art. 149, alterado pela Lei 10.803/2003. Assim, esse dispositivo criminaliza as práticas de trabalhos forçados, cerceamento da liberdade por isolamento geográfico ou dívida, trabalho com jornadas exaustivas e condições degradantes por considerá-las maneiras de reduzir o indivíduo a condição análoga à de escravo ${ }^{10}$.

Estudos da Organização Internacional do trabalho, através do seu escritório sediado no Brasil, manifesta-se em relação à redação do art. 149 do Código Penal:

\footnotetext{
${ }^{9}$ III-ninguém será submetido a tortura nem a tratamento desumano ou degradante; XLVII-não haverá penas: a) de morte, salvo em caso de guerra declarada, nos termos do art. 84, XIX; b) de caráter perpétuo; c) de trabalhos forçados;

${ }^{10}$ Art. 149. Reduzir alguém a condição análoga à de escravo, quer submetendo-o a trabalhos forçados ou a jornada exaustiva, quer sujeitando-o a condições degradantes de trabalho, quer restringindo, por qualquer meio, sua locomoção em razão de dívida contraída com o empregador ou preposto: Pena - reclusão, de dois a oito anos, e multa, além da pena correspondente à violência. § $1^{\circ}$ Nas mesmas penas incorre quem: I - cerceia o uso de qualquer meio de transporte por parte do trabalhador, com o fim de retê-lo no local de trabalho; II - mantém vigilância ostensiva no local de trabalho ou se apodera de documentos ou de objetos pessoais do trabalhador, com o fim de retê-lo no local do trabalho. $\S 2^{\circ}$ A pena é aumentada de metade, se o crime é cometido: I - contra criança e adolescente; II - por motivo de preconceito de raça, cor, etnia, religião ou origem.
} 
Com uma definição mais clara de "trabalho escravo", as leis nacionais relativas à exploração do trabalho puderam atender às características específicas do trabalho forçado no Brasil, ao mesmo tempo em que contemplaram as disposições das convenções da OIT que visam abolir a prática de trabalho forçado no mundo. Desse modo, é o artigo 149 do Código Penal Brasileiro (CPB) e a convenção da OIT n ${ }^{\circ} 29$ que fornecem um amparo legal necessário às ações de combate ao trabalho escravo no Brasil. (OIT/ILO, 2010, p. 35) ${ }^{11}$.

Resta evidente que a conceituação trazida pelo Código Penal Brasileiro se encontra em total harmonia com as normatizações internacionais contra trabalhos forçados, devidamente ratificadas pelo Brasil, uma vez que se complementam para respaldar a atuação do brasil no enfrentamento das práticas escravagistas.

Importante mencionar que o Brasil reconheceu a jurisdição da Corte Interamericana de Direitos Humanos - Corte IDH, em 1998, bem como a do Tribunal Penal Internacional em 2002, incorporando um sistema universal de proteção dos direitos humanos. Desta forma, a interpretação do termo trabalho escravo não pode está em desarmonia com os tratados internacionais de direitos humanos ratificados pelo país, o que abre a possibilidade de questionamentos perante a Corte IDH ou outros organismos internacionais, a exemplo da OIT, a fim de que seja impelido ao cumprimento da interpretação fixada internacionalmente na busca da máxima efetividade dos direitos humanos. (Ramos, 2016, p. 392).

Nesse contexto, é importante mencionar a condenação do Brasil perante a Corte Interamericana de Direitos Humanos - CIDH, quando foi responsabilizado ao tomar conhecimento da submissão de trabalhadores da Fazenda Brasil Verde à trabalhos forçados e servidão por dívidas no ano de 1989 e ter permanecido inerte, quando não adotou as medidas de prevenção, repressão e reparação pelas condutas perpetradas contra os trabalhadores. Ademais, determinou a reabertura das investigações criminais para a devida punição e reparação das vítimas ${ }^{12}$.

Decerto que a alteração do artigo 149 do Código Penal, através da Lei nº 10.803/2003, contribuiu para a ampliação do bem jurídico protegido, uma vez que não se restringiu a especificar o cerceamento da liberdade de locomoção do trabalhador, passando a incluir as condições degradantes de trabalho, as jornadas exaustivas de trabalho e os trabalhos forçados

\footnotetext{
${ }^{11}$ É importante mencionar que as modificações realizadas no art. 149 do CPB constitui parte da execução do acordo Solução Amistosa assinado entre o Brasil e a Comissão Pastoral da Terra, Center for Justice and International Law (Centro pela Justiça e o direito Internacional) e Human Rights Watch, momento em que o Brasil se comprometeu a envidar esforços para que o crime de redução da pessoa a condição análoga à de escravo fosse processado e julgado como crime. Em que pese as alterações terem contribuído para a punição desse crime, as penas continuaram muito baixas, não acatando a sugestão do $1^{\circ}$ Plano Nacional para a Erradicação do Trabalho Escravo, consoante Relatório CEJIL de 2007, dificultando a sua erradicação. (OIT/ILO, 2010, p. 53).

${ }^{12}$ Para um maior aprofundamento do caso consultar o site: http://www.itamaraty.gov.br.
} 
como modalidades modernas de configuração do delito em análise, o que demonstra nitidamente, a referida ampliação, a consonância com o vetor axiológico da dignidade da pessoa humana.

Britto Filho (2018, p. 88) aponta que mesmo após alguns anos de vigência do dispositivo alterado, subsiste posições divergentes, principalmente, entre os agentes que atuam no combate do trabalho escravo, o que contribui para beneficiar empregadores que exploram as forças humanas do trabalhador em desrespeito à sua dignidade. Salienta que antes da alteração normativa a posição dominante da doutrina e jurisprudência era no sentido de que o bem jurídico tutelado era a liberdade de locomoção, o que era justificado pelo fato do dispositivo legal trazer a proibição de forma genérica “Art. 149. Reduzir alguém à condição análoga à de escravo", bem como pela localização topológica do texto legal, situando-se no Título I - Dos crimes contra a pessoa, Capítulo IV - dos crimes contra a liberdade individual, na Seção I - dos crimes contra a liberdade pessoal.

Para o autor, em que pese a posição dominante ser que o bem jurídico maior a ser tutelado fosse a liberdade, antes da alteração, este por si só já abrangia a proteção da dignidade do indivíduo, uma vez que para que houvesse a tipificação do delito deveria estar presente a relação de prestação de serviços com relação de domínio do empregador sobre o indivíduo, com a completa anulação da vontade deste. (BRITO FILHO, 2018, p. 89)

Salienta-se que o Tribunal Pleno do STF, em acordão de relatoria da Min. Rosa Weber, julgado em 29 de março de 2012, decidiu-se que para a configuração do crime do art. 149 do Código Penal, não é necessário que se prove a coação física da liberdade de ir e vir ou o cerceamento da liberdade de locomoção, sendo suficiente a submissão da vítima a trabalhos forçados ou a jornada exaustiva ou a condições degradantes de trabalho. Entendeu a Corte que por ser a escravidão moderna mais sutil do que a do século XIX, a cerceamento da liberdade pode decorrer de diversos constrangimentos econômicos e não necessariamente físicos. Tratar o sujeito como coisa e não como pessoa humana pode se dar mediante a violação intensa e persistente de seus direitos básicos, inclusive do direito ao trabalho digno. ${ }^{13}$

Apesar do Código Penal prever de forma autoexplicativa as condutas tipificadoras do delito, apresenta duas hipóteses frutos da alteração, quais sejam: jornadas excessivas e condições degradantes de trabalho que demandam um esforço maior dos intérpretes,

\footnotetext{
${ }^{13}$ STF. Inquérito n. 3412/AL. Rel. Min. Marco Aurélio. Relatora para acórdão Min. Rosa Weber. Julgamento: 29 de março de 2012. Órgão Julgador: Tribunal Pleno. Ementa: PENAL. REDUÇÃO À CONDIÇÃO ANÁLOGA À DE ESCRAVO. ESCRAVIDÃO MODERNA. DESNECESSIDADE DE COAÇÃO DIRETA CONTRA A LIBERDADE DE IR E VIR. DENÚNCIA RECEBIDA. Disponível em: www.stf.jus.br. Acesso em 24 de setembro de 2017.
} 
acarretando divergências e dificuldades para os órgãos responsáveis pelo enfrentamento do trabalho escravo, o que dificulta o seu combate de forma efetiva. (BRITO FILHO, 2016, p. 87).

Rogério Greco posiciona-se no que concerne à jornada excessiva como sendo as horas laboradas suficientes para aniquilar completamente as forças do trabalhador, afetando sobremaneira sua saúde física e mental, o que difere da simples ausência do controle de horas. A presunção jamais poderá ser utilizada nessa análise. (GRECO, 2010). Nessa modalidade, exige-se do obreiro prestação de trabalho além do normalmente exigido, com o objetivo exclusivo de beneficiar o empregador.

Note-se que apesar do termo em análise trazer um conceito jurídico indeterminado, ele pode ser ligado a critérios objetivos presentes na legislação trabalhista, contribuindo para uma fácil percepção da configuração da superexploração laboral configuradora da prática escravocrata. É o que ocorre, por exemplo, quando o trabalhador é submetido, habitualmente, a jornadas de trabalho de 14 a 16 horas.

No tocante às condições degradantes de trabalho, Britto Filho (2016) assevera que se configura com a falta de garantias mínimas de saúde, segurança e trabalho, moradia, higiene, respeito e alimentação, sendo que a falta de um desses é suficiente para o reconhecimento do trabalho escravo. Negam-se direitos básicos ao trabalhador, privando-o da sua dignidade, desconsiderando-o como sujeito de direitos, deteriorando a sua saúde.

Haddad (2013, p. 57) possui posicionamento semelhante ao discorrer:

(...)O trabalho que explora a miséria e a necessidade do trabalhador viola a dignidade da pessoa e é, portanto, degradante, independentemente do fato de as habituais condições de vida dele não serem comparativamente melhores. Uma coisa é a miséria como condição pessoal; outra, como palco em que se encena a exploração. Se o empregador pode fornecer condições dignas de labor, mas se omite em assim proceder, deixa clara a intenção de exploração predatória da força de trabalho, revela o dolo que informa sua conduta e autoriza incida o juízo de reprovação pela culpabilidade demonstrada.

Nesses termos, a privação da liberdade não é o fator determinante para que o crime se tipifique, sendo necessário que haja a relação de domínio entre o autor e a vítima. Outro fato importante a ser constatado é que esse domínio deve ser suficiente para anular a vontade da pessoa escravizada. (BRITTO FILHO, 2016).

Oportuno destacar o posicionamento de Mannrich (2018, p. 146) em relação à incorporação dos termos indeterminados, jornadas exaustivas e condições degradantes de trabalho, ao conceito de trabalho escravo moderno presente no art. 149 do Código Penal, através da Lei $n^{\circ} 10.803 / 2003$ : 
Respeitável doutrina defende a manutenção dos conceitos amplos presentes nos atos normativos do Ministério do Trabalho e mesmo no Código penal. Confunde-se trabalho em condições análogas à de escravo com trabalho precário, ou seja, a antítese do trabalho decente. As expressões "jornada exaustiva" e trabalho degradante" podem se distanciar da noção de trabalho decente e poderiam formar parte das definições de trabalho precário, mas não de trabalho escravo ou análogo à de escravo. De fato, referidas expressões são associadas à violação da segurança e dignidade do ser humano, valores que integram o conceito de trabalho decente.

Mannrich (2018, p. 146) aponta, ainda, para a necessidade de se proceder à conceituação adequada do trabalho escravo, a fim de se evitar a subjetividade e agregar a eficácia para punir de forma adequada o empregador.

Por fim, ressalte-se que no ordenamento jurídico pátrio houve a alteração do art. 243 da Constituição Federal pela Emenda Constitucional $n^{\circ}$ 81, de 2004, passando a prever a expropriação de propriedades rurais e urbanas onde forem encontradas práticas escravocratas, assim como a apreensão de todo e qualquer bem de valor econômico encontrados nessas terras. ${ }^{14}$ A despeito de se tratar de norma de eficácia limitada, essa disposição constitucional adveio com o objetivo de ser mais um mecanismo para ensejar a erradicação do trabalho em condição de escravidão contemporânea. ${ }^{15}$

O combate a escravidão moderna é assunto que assume relevância em todos os países que estão envidando esforços no sentido de proceder à atualização de suas normatizações, a fim de trilhar um caminho viável para a sua erradicação. Esse fato pode ser corroborado com a edição da Lei contra o Trabalho Escravo Moderno, a ser realizada no final de 2018, pela Austrália. Atualmente, utiliza como base a Lei contra o Trabalho Escravo do Reino Unido, editada em $2015 .^{16}$

Nesse sentido, a comissão do Parlamento australiano informa que ${ }^{17}$ :

\footnotetext{
${ }^{14}$ Art. 243. As propriedades rurais e urbanas de qualquer região do País onde forem localizadas culturas ilegais de plantas psicotrópicas ou a exploração de trabalho escravo na forma da lei serão expropriadas e destinadas à reforma agrária e a programas de habitação popular, sem qualquer indenização ao proprietário e sem prejuízo de outras sanções previstas em lei, observado, no que couber, o disposto no art. $5^{\circ}$. Parágrafo único. Todo e qualquer bem de valor econômico apreendido em decorrência do tráfico ilícito de entorpecentes e drogas afins e da exploração do trabalho escravo será confiscado e reverterá a fundo especial com destinação específica, na forma da lei.

${ }^{15}$ Impende, ainda, mencionar um Projeto de Lei $n^{\circ} 432 / 13$ que visa regulamentar a EC $\mathrm{n}^{\circ}$ 81. Tal projeto também é considerado um retrocesso, posto que intenciona excluir duas modalidades consideradas modernas na delimitação do trabalho escravo, quais sejam: jornada excessiva de trabalho e condição degradante de trabalho do conceito legal do trabalho escravo contida no art. 149 do Código Penal brasileiro.

${ }^{16}$ Disponível em: https://www.business-humanrights.org/en/inquiry-into-establishment-of-a-modern-slavery-actin-australia

${ }^{17}$ Disponível em: https://www.aph.gov.au/Parliamentary_Business/Committees/Joint/Foreign_Affairs _Defence_and_Trade/ModernSlavery/Terms_of_Reference. Acesso em 10 de maio de 2018.
} 
With reference to the United Kingdom's Modern Slavery Act 2015 and to relevant findings from the Joint Standing Committee on Foreign Affairs, Defence and Trade's report, Trading Lives: Modern Day Human Trafficking, the Committee shall examine whether Australia should adopt a comparable Modern Slavery Act. The Committee shall have particular regard to: the nature and extent of modern slavery (including slavery, forced labour and wage exploitation, involuntary servitude, debt bondage, human trafficking, forced marriage and other slavery-like exploitation) both in Australia and globally; the prevalence of modern slavery in the domestic and global supply chains of companies, businesses and organisations operating in Australia ${ }^{18}$.

Impende destacar uma ação importante de combate da escravidão moderna no Brasil, que é o cadastro de empregadores infratores, denominado também de "lista suja”, criada através da portaria 540, de 15 de outubro de 2004, expedida pelo Ministério Público do Trabalho e Emprego. Essa lista relaciona os nomes dos empregadores, tanto de pessoas físicas e como de jurídicas autuadas pela prática do trabalho escravo.

Em face da não aplicação da portaria interministerial n. 04/2016, o Ministério Público do Trabalho uma Ação Civil Pública n. ACP-1704-55.2016.5.10.0011, da lavra dos procuradores do trabalho Breno da Silva Maia Filho, Thiago Muniz Cavalcante Maurício Ferreira Brito, distribuída na $11^{\text {a }}$ Vara do Trabalho do Distrito Federal, obtendo decisão liminar para determinar à União Federal que divulgasse o cadastro dos empregadores infratores. Contra a concessão da liminar, a União moveu pedido de suspensão de segurança em caráter liminar junto ao presidente do TST para suspender os efeitos da decisão proferida pelo juiz da $10^{\mathrm{a}}$ Vara do Trabalho do Distrito Federal. Esse pedido da União foi acolhido pelo Presidente do TST, Min. Ives Gandra Martins Filho adiando a divulgação da chamada lista suja. Contra esta decisão foi impetrado Mandado de Segurança pelo Ministério Público do Trabalho para cassar a decisão proferida pela presidência do $\mathrm{TST}^{19}$, da lavra do subprocurador-geral do trabalho Manoel Jorge e Silva Neto. ${ }^{20}$

\section{A conceituação do trabalho em condições análogas a de escravo imersa na portaria ministerial 1.129/2017 e a aplicação do princípio do não retrocesso social}

\footnotetext{
${ }^{18}$ A comissão do parlamento australiano está predisposta a examinar se a Austrália deve adotar uma legislação contemporânea levando-se em consideração a legislação do Reino Unido de 2015. Essa comissão leva em consideração fatores domésticos sobre a escravidão na Austrália e a nível global, de forma a identificar as melhores práticas empregadas pelos governos a nível internacional, bem como pelas empresas e demais organizações no intuito de prevenir a escravidão contemporânea com uma visão voltada para a Legislação Australiana.

${ }^{19}$ Vide inteiro teor do Mandado de Segurança n. ${ }^{\circ}$ TST-MS-3351-63.2017.5.00.0000. Disponível em: http://cdn01.justificando.cartacapital.com.br/wp-content/uploads/2017/03/16143900/41157_2017_14895 28800000.pdf

${ }^{20} \mathrm{O}$ subprocurador-geral do trabalho aduziu, em seu pedido, que a portaria interministerial n. 04/2016 tem por finalidade dar transparência aos atos administrativos resultantes de ações fiscais que flagraram a exploração do trabalho a condições análogas a de escravo, e que o retardo quanto a publicação enseja dano irreparável a sociedade como um todo.
} 
Com a instituição do Estado Social, estabelece-se um sentimento de que todas as conquistas efetivadas por meio de normas constitucionais e infraconstitucionais não retrocedem para prejudicar a condição social do trabalhador. Os direitos sociais, as liberdades públicas tendem a se desenvolver e a avançar, sendo inadmitido o retrocesso, o que seria incompatível com a própria natureza da Constituição Federal. (Meireles, 2007).

O princípio do não retrocesso social pode ser extraído tanto do Pacto Internacional dos Direitos Econômicos, Sociais e Culturais de 1966, em seu art. $5^{\circ}, 2^{21}$, como também do art. $5^{\circ}$, do Pacto Internacional dos Direitos Civis e Políticos ${ }^{22}$.

No Brasil, o princípio do retrocesso social pode ser extraído, implicitamente, da parte final do caput do art. $7^{\circ}$ da Constituição Federal, ao estabelecer o rol dos direitos dos trabalhadores e especificar "além de outros que visem à melhoria da sua condição social".

Nesse toar, José Joaquim Gomes Canotilho (2000, p. 446) afirma que:

O princípio da não retroatividade não é um princípio constitucional irrestritamente válido na ordem jurídica portuguesa (cfr. Supra), mas é-o, sem quaisquer exceções, no que respeita as leis restritivas de direitos, liberdades e garantias ou direitos análogos (cfr. arts. $18^{\circ} / 3$ e $17^{\circ}$. Com a LC n ${ }^{\circ} 1 / 82$, o princípio da não retroatividade deixou de ser um princípio circunscrito ao âmbito penal (cfr. art. $2^{\circ}$ ) para passar a princípio geral das leis restritivas de direitos, liberdades e garantias [...]

A Portaria 1.129, publicada em 16 de outubro de 2017, dispõe sobre o conceito de trabalho em condições análogas à de escravo, jornada exaustiva, trabalho forçado e condições degradantes de trabalho, para fins de concessão do seguro-desemprego dos trabalhadores que forem resgatados nessa situação.

Tal portaria vinha sendo alvo de sérias críticas pelos profissionais que compõem os órgãos de repressão e combate ao trabalho escravo, sob o fundamento de que o dispositivo legislativo esvaziou o conceito já consolidado na doutrina e jurisprudência, consoante a alteração do art. 149 do código penal já analisado no item anterior, o qual, ao elencar as modalidades de configuração do delito em tela, ampliou o objeto jurídico, passando a constituílo como cerceamento da liberdade de ir e vir e proteção da dignidade da pessoa humana.

$21 \mathrm{O}$ Art. $5^{\circ}$, 2. Não se admitirá qualquer restrição ou suspensão dos direitos humanos fundamentais reconhecidos ou vigentes em qualquer país em virtude de leis, convenções, regulamentos ou costumes, sob o pretexto de que o presente Pacto não os reconheça ou os reconheça em menor grau.

${ }^{22}$ Art. $5^{\circ}$. Não se admitirá qualquer restrição ou suspensão dos direitos humanos fundamentais reconhecidos ou vigentes em qualquer Estado-parte no presente Pacto em virtude de leis, convenções, regulamentos ou costumes, sob pretexto de que o presente Pacto não os reconheça ou nos reconheça em menos grau. 
A presente portaria conceituou as modalidades de escravidão contemporânea no artigo $1^{023}$ e impôs novos obstáculos para a caracterização das modalidades modernas, jornadas exaustivas e condições degradantes de trabalho, condicionando-as à restrição da liberdade de ir e vir. Portanto, a portaria, em análise, dificultou a possibilidade de preenchimento das condições exigidas pelo instrumento legislativo, o que obstaculiza os procedimentos de repressão e controle dessa prática abusiva.

O conceito de trabalho escravo não pode se restringir ao conteúdo disposto na portaria, não só por ser a mesma uma norma de caráter administrativo, mas também pelo fato de que o conceito da escravidão contemporânea para alcançar a sua erradicação se utiliza de elementos externos ao direito positivo em análise, sendo assim um conceito amplo e abstrato.

Tal conduta reflete afronta ao Princípio do não retrocesso social, porque a restrição da definição de trabalho escravo não objetiva a melhoria da condição social do trabalhador por dificultar a efetivação das políticas de prevenção e repressão da prática escravagista.

Importante destacar a decisão da Min. Rosa Weber em sede de liminar concedida na Arguição de Descumprimento de Preceito Fundamental 489/ Distrito Federal, ajuizada pela Rede Sustentabilidade em face da Portaria do Ministério do Trabalho ${ }^{\circ} 1.129 / 2017$, para suspender os efeitos do referido ato normativo sob a fundamentação de que viola as dimensões de repressão, prevenção e reparação das ações desenvolvidas pelos organismos responsáveis pelo combate da escravidão moderna.

Tal portaria foi cancelada e posteriormente editada outra em seu lugar sob a seguinte numeração Portaria MTB 1.293 de 28 de dezembro de 2017, a qual apresenta nova conceituação para o trabalho escravo contemporâneo, retirando o cerceamento de liberdade em relação às modalidades protetivas da dignidade humana, como: jornadas excessivas e condições degradantes de trabalho.

\footnotetext{
${ }^{23}$ Art. $1^{\circ}(\ldots)$ I - trabalho forçado: aquele exercido sem o consentimento por parte do trabalhador e que lhe retire a possibilidade de expressar sua vontade; II - jornada exaustiva: a submissão do trabalhador, contra a sua vontade e com privação do direito de ir e vir, a trabalho fora dos ditames legais aplicáveis a sua categoria; III - condição degradante: caracterizada por atos comissivos de violação dos direitos fundamentais da pessoa do trabalhador, consubstanciados no cerceamento da liberdade de ir e vir, seja por meios morais ou físicos, e que impliquem na privação da sua dignidade; IV - condição análoga à de escravo:

a) a submissão do trabalhador a trabalho exigido sob ameaça de punição, com uso de coação, realizado de maneira involuntária; b) o cerceamento do uso de qualquer meio de transporte por parte do trabalhador, com o fim de retêlo no local de trabalho em razão de dívida contraída com o empregador ou preposto, caracterizando isolamento geográfico; c) a manutenção de segurança armada com o fim de reter o trabalhador no local de trabalho em razão de dívida contraída com o empregador ou preposto; d) a retenção de documentação pessoal do trabalhador, com o fim de reter o trabalhador no local de trabalho;
} 
A indeterminação em relação ao conceito de trabalho escravo, ligando-o estritamente às modalidades de cerceamento da liberdade ou ampliando o seu conteúdo para abranger a proteção da dignidade humana, através das modalidades jornadas exaustivas e condições degradantes de trabalho, bem como a própria significação do conteúdo dessas modalidades subjetivas de escravidão, contribui para a ocorrência de edição de normas como a Portaria MTB 1.129/2017, a qual objetivava a restrição do conceito de trabalho escrevo moderno.

Tal fato também contribui para a existência de projetos de leis tanto no Senado Federal $^{24}$ quanto na Câmara dos Deputados ${ }^{25}$, que objetiva a restrição ao alcance conceitual do trabalho escravo contemporâneo, por isso a importância de colacionar o conteúdo da portaria anulada, tendo em vista que tal restrição dificulta a tipificação do delito redução da pessoa à condição análoga a de escravo, com a devida punição dos envolvidos na prática delituosa.

Verifica-se, então, que a restrição do alcance do conceito de trabalho escravo afeta negativamente as políticas públicas efetivadas para à proteção da dignidade da pessoa humana, o combate ao trabalho escravo, além de estarem em dissonância com os instrumentos normativos internacionais ratificados pelo Brasil e com o ordenamento jurídico vigente, além de afrontar o princípio do não retrocesso social.

Em 2003, tanto o STF como a jurisprudência univocamente decidiram que apesar desse crime estar alocado no Capítulo dos crimes contra a liberdade, trata-se de um crime contra a organização do trabalho de competência da justiça comum federal. A respeito desse entendimento tem-se o RE 459510/MT - Mato Grosso, cujo relator foi o Ministro Cezar Peluso, julgado em 26 de novembro de $2015 .{ }^{26}$.

Impende mencionar que esse fato constitui também uma das razões a corroborar com a divergência de um posicionamento uniforme com relação à significação dos termos abertos jornadas exaustivas e condições degradantes de trabalho, posto que a justiça do trabalho seria,

\footnotetext{
${ }^{24}$ Como exemplo, tem-se o projeto de lei do senado ${ }^{\circ} 432 / 2013$, o qual objetiva regularizar a EC 81/2014 ao prever a expropriação de imóveis em que for encontrado com a utilização de mão de obra escrava e o confisco de bens confeccionados através da exploração escravocrata. Impende destacar que esse projeto visa excluir as modalidades jornadas exaustivas e condições degradantes de trabalho do conceito de trabalho escravo existente no art. 149 do CP. Disponível em: https://www25.senado.leg.br/web/atividade/materias/-/materia/114895.

25 No mesmo sentido, o projeto de lei da Câmara dos Deputados $\mathrm{n}^{\circ}$ 2464/2015, disponível em : http://www.camara.gov.br/proposicoesWeb/fichadetramitacao?idProposicao $=1594511$ e o projeto de lei $\mathrm{n}^{\circ}$ 3842/2012, disponível em: http://www.camara.gov.br/proposicoesWeb/fichadetramitacao?idProposicao

$=544185$, todos visando a revisão conceitual restritiva do trabalho escravo contemporâneo, presente no art. 149 do $\mathrm{CP}$, que surgiram após a edição da $\mathrm{EC} \mathrm{n}^{\circ}$ 81/2014.

26 Ementa: RECURSO EXTRAORDINÁRIO. CONSTITUCIONAL. PENAL. PROCESSUAL PENAL. COMPETÊNCIA. REDUÇÃO A CONDIÇÃO ANÁLOGA À DE ESCRAVO. CONDUTA TIPIFICADA NO ART. 149 DO CÓDIGO PENAL. CRIME CONTRA A ORGANIZAÇÃO DO TRABALHO. COMPETÊNCIA DA JUSTIÇA FEDERAL. ARTIGO 109, INCISO VI, DA CONSTITUIÇÃO FEDERAL. CONHECIMENTO E PROVIMENTO DO RECURSO. Disponível em: www.stf.jus.br. Acesso em 24 de setembro de 2017.
} 
especialmente, a mais apta a identificar, no caso concreto, se tais condutas constituem meras irregularidades trabalhistas ou se são aptas a configurar o crime de redução da pessoa à condição análoga a de escravo.

\section{A dogmática jurídica e a interpretação do conceito do trabalho escravo no ordenamento jurídico brasileiro}

Para a compreensão do alcance do conceito do trabalho escravo, torna-se imperioso tecer breves considerações a respeito dos sistemas externo e interno da ordem posta para fins de interpretação de uma norma jurídica. Para tanto, torna-se essencial o entendimento das conexões de sentido em que as normas se encontram entre si e com os princípios do ordenamento jurídico, possibilitando uma visão de conjunto na forma de um sistema.

O sistema de conceitos gerais abstratos, também denominado de sistema externo, fundamenta-se na separação e generalização, a partir de fatos-tipo que são objeto de uma regulação jurídica, formando-se conceitos de gênero que são ordenados com o fim de alcançar diversos graus de abstração. Os conceitos inferiores, de menor grau de abstração, ao serem subsumidos aos conceitos superiores correspondentes reconduzem à ordem jurídica alguns poucos conceitos supremos. (LARENZ, 2014, p. 622).

Em relação ao sistema interno, tem-se que os princípios diretivos que o representa tem por objetivo tornar visível e por em evidência a unidade valorativa interna do ordenamento jurídico. Nesse toar, a formação de determinados conceitos a serem observados pelas demais normas compostas no ordenamento jurídico devem estar em consonância com os valores representados por esses princípios e que são compatíveis com os conceitos de gênero absorvidos por esse sistema. Um sistema compreendido como tal garante uma maior clareza e segurança jurídica, resguardando a ausência de contradição lógica de todas as consequências dele derivadas. (LARENZ, 2014, p. 622-623).

A Portaria $\mathrm{n}^{\mathrm{o}} 1.129 / 17$, ao trazer o conceito do trabalho escravo moderno, incorporou um tipo conceitual restritivo, distanciando da compreensão absorvida nos diplomas internacionais de proteção dos direitos humanos, o que também ocorre com os projetos de leis em trâmite na Câmara dos Deputados e do Senado Federal. Dessa forma, a não abertura para a inclusão dos conceitos externos contribui para o retrocesso conceitual do trabalho escravo moderno, restringindo os direitos daqueles que são alvo dessa prática abusiva. Não há como analisar o conceito do trabalho escravo isoladamente dentro de um sistema fechado da ordem jurídica interna, tendo em vista que tal definição sofre influência externa de outros sistemas. 
Nota-se que tal comportamento reduz ao sistema fechado essa conceituação, o que não é permitido, uma vez que gera um retrocesso ao sistema aberto que são outros sistemas sociológicos, cognitivos, externos ao direito e que emprestam ao direito a conceituação do que é trabalho escravo. A portaria, ao reduzir uma conceituação, limita o conceito aberto e atual do que vem a ser trabalho escravo a nível universal, gera um retrocesso por restringir direitos dos cidadãos prejudicados com tal ato.

Percebe-se, então, que a melhor interpretação que se dá ao trabalho escravo é aquela que foi recepcionada pelo texto constitucional que amplia a concepção de proteção das vítimas da escravidão contemporânea, o que faz com que a norma infraconstitucional não possa restringir a compreensão do significado.

Nesse diapasão, o conceito sociológico e jurídico do termo trabalho escravo, principalmente a nível das legislações que foram recepcionadas pelo ordenamento jurídico brasileiro, constitui conceito bem mais amplo de cunho sociológico que devem ser absorvidas pelas normas internas para que possa haver a devida integração.

Imprescindível, ainda, fazer uma análise sistemática das diversas ordens jurídicas a fim de demonstrar a interdependência das normas para o desenvolvimento dos meios de proteção mais eficazes contra a escravidão contemporânea. Karl Larenz (2014, p. 621) aduz que as normas jurídicas se encontram ligadas uma as outras, uma vez que há a interpenetração entre as mesmas. Acrescenta que a interpretação das normas jurídicas deve ser realizada com observância da cadeia do significado, do contexto e da sede sistemática da norma. Desta forma, o ordenamento jurídico deve ser analisado em sua totalidade, subordinando-se a princípios ou valores relacionados a determinadas ideias jurídicas diretivas, cuja função é unificar as normas e excluir as contradições de valoração.

A unicidade da ordem jurídica interna demanda um conjunto de regras responsáveis pela composição do todo com a presença de princípios reguladores da atividade interpretativa, ao quais se diferem das regras gerais apesar de serem caracterizados pela generalidade. Entretanto, apesar de ambos possuírem a generalidade, a dos princípios é verificada num grau mais elevado porque não está vinculado a série definidas de casos. (FERRAZ JÚNIOR, 2014, 98-99).

Por conseguinte, a interpretação deve partir dos princípios universais maiores até se alcançar as normas jurídicas específicas, uma vez que aqueles constituem o fundamento de validade destas. Assim, os princípios assumem papel relevante na interpretação e aplicação das normas jurídicas e contrariá-los representa o rompimento com o sistema jurídico ao qual a norma está inserida, afetando seus valores fundamentais. 
Nessa ordem de ideias, tem-se o modelo hermenêutico da dogmática jurídica, incorporando uma atividade interpretativa edificando um sistema teórico do comportamento humano, ao privilegiar a função avaliativa por se debruçar na semântica, na busca do sentido dos atos, das normas e das instituições, evidenciando seu postulado quase unânime de que não há norma sem interpretação. (FERRAZ JÚNIOR, 2015, p. 136)

A partir do momento que interpretar deixa de ser uma questão técnica e passa a ser um objeto de reflexão, através da construção de uma teoria, o ato da interpretação passa a ser o sentido que o texto expressa e não o próprio texto em si, sendo que o sentido expresso no texto é determinado previamente por outro ato interpretativo da autoridade competente pela elaboração da norma. (FERRAZ JÚNIOR, 2015, 139-140). Aqui, resta comprovada a não observância da unidade dos dispositivos existente na ordem jurídica vigente, relativos ao significado do trabalho escravo, com a devida análise e interpretação, a fim de que fosse utilizado o real significado do termo na época da elaboração da portaria ministerial anulada anteriormente mencionada, com também dos projetos de leis existente referentes ao tema em análise.

Consequentemente, importante trazer à baila as técnicas de interpretação apresentadas por Ferraz Júnior (2014, 91-99), segundo o qual a primeira tarefa do intérprete consiste em extrair uma definição dos termos, que oscilará entre os aspectos onomasiológico e semasiológico do termo. ${ }^{27}$ Ao fazer uso destes aspectos, o intérprete utiliza o vocábulo da linguagem cotidiana, atribuindo-lhe um sentido técnico, em consonância com o sentido usual. Trata-se da interpretação gramatical, onde é buscado o sentido literal da palavra.

Superado o ponto de partida, passa-se a técnica ligada ao princípio da coerência, observando-se a exigência da compatibilidade em detrimento do princípio lógico da ausência da contrariedade. Ferraz Júnior (2014, p. 96) posiciona-se no sentido de que:

(...) A própria determinação de certos critérios de coerência exige que o texto normativo seja visualizado num corpo maior, donde a chamada interpretação sistemática, aqui entendida, em termos de Savigny, como a busca do sentido global da norma num conjunto abarcante.

A interpretação sistemática, quando tomada em sentido não formal, envolve sempre uma teologia. Há um sentido normativo a ser determinado, e este sentido implica a captação dos fins para os quais a norma é construída. A percepção dos fins não é imanente a cada norma tomada isoladamente, mas exige uma visão ampliada da norma dentro do ordenamento.

\footnotetext{
${ }^{27}$ Aspecto onomasiológico refere-se ao uso corrente da palavra para determinação do fato, observando-se as mutações das palavras e o aspecto semasiológico, significa a sua significação normativa, em busca de pensamento. (FERRAZ JÚNIOR, 2014, p.92)
} 
Qualquer dispositivo legal poderá tratar da conceituação ou elencar hipóteses em que seja configurado a situação analisada, bem como regulamentar o procedimento fiscalizatório, desde que não vá de encontro aos diplomas legislativos referentes ao tema em comento. No momento em que desconsiderar a existência dessas legislações, passa a ser considerado inconstitucional, contribuindo para o retrocesso da conceituação moderna do trabalho escravo.

\section{Conclusão}

Conclui-se, desta forma, que qualquer dispositivo legal que restringir o conceito da escravidão no ordenamento quando se compara com conceitos trazidos de outros sistemas violará a dignidade da pessoa humana. Destaque-se que o conceito atual da escravidão moderna presente no Código Penal, é considerado referência pela Organização Internacional, no combate à modalidade laborativa escravocrata. Além disso, encontra-se em consonância com as Convenções 29 e 105 das Nações Unidas sobre Escravatura.

A restrição conceitual do trabalho escravo moderno é contrária aos precedentes do STF sobre a temática, por já ter entendimentos firmados no sentido de que jornada exaustiva e condições degradantes constituem elementos do tipo penal caracterizadores da redução da pessoa à condição análoga a de escravo, posicionando incontestavelmente em relação à desnecessidade da presença de uma coação direta contra a liberdade de ir e vir.

Então, uma norma interna, principalmente uma portaria, que é uma norma infralegal, por ser um ato de caráter administrativo, que possui um valor normativo para fins de procedimentalizar os processos de fiscalização e da autuação da administração pública, não pode jamais definir ou conceituar de modo a restringir esses valores protegidos a nível constitucional e externo.

A portaria pode tratar da conceituação ou elencar hipóteses em que seja configurado a situação analisada, bem como regulamentar o procedimento fiscalizatório, desde que não vá de encontro aos diplomas legislativos referentes ao tema em comento. No momento em que se desconsidera a existência dessas legislações, passa a ser considerado inconstitucional, contribuindo para o retrocesso da conceituação moderna do trabalho escravo.

Constata-se que qualquer dispositivo legal poderá tratar da conceituação ou elencar hipóteses em que seja configurado a situação analisada, bem como regulamentar o procedimento fiscalizatório, desde que não contrarie os diplomas legislativos referentes ao tema em comento. Ao desconsiderar a existência dessas normatizações, passa a ser considerado inconstitucional, contribuindo para o retrocesso da conceituação moderna do trabalho escravo. 
Dessa forma, resta demonstrada a desnecessidade de uma conceituação expressa do trabalho escravo contemporâneo, uma vez que a análise interpretativa e sistemática dos diplomas legais correlatos, leva-nos a melhor conceituação da conduta exploradora do trabalho humano, para englobar tanto o cerceamento da liberdade de locomoção quanto à proteção da dignidade humana.

\section{Referências bibliográficas}

BRASIL. Constituição (1988). Constituição da República Federativa do Brasil. Brasília, DF: Senado, 1988.

BRASIL. Decreto-lei no 2.848, de 7 de dezembro de 1940. Institui o Código Penal Brasileiro. Disponível em: < http://www.planalto.gov.br/ccivil_03/decretolei/Del2848compilado.htm>. Acesso em: 30 de março de 2017.

BRASIL. CÂMARA DOS DEPUTADOS. Projeto de Lei n 3842/2012. Disponível em: http://www.camara.gov.br/proposicoesWeb/fichadetramitacao?idProposicao=544185. Acesso em: 20 de abril de 2018.

BRASIL. CÂMARA DOS DEPUTADOS. Projeto de Lei n 2464/2015. Disponível em: http://www.camara.gov.br/proposicoesWeb/fichadetramitacao?idProposicao=1594511. Acesso em: 29 de abril de 2018.

BRASIL. SENADO FEDERAL. Projeto de Lei n 432/2013. Disponível em: https://www25.senado.leg.br/web/atividade/materias/-/materia/114895. Acesso em: 29 de abril de 2018.

BRITO FILHO, José Cláudio Monteiro de. Teorias da justiça e trabalho decente. In: Direitos Humanos dos Trabalhadores. Rúbia Zanotelli de Alvarenga (org). São Paulo: LTr Editora, 2016.

BRITO FILHO. José Cláudio Monteiro de. Trabalho decente: análise jurídica da exploração do trabalho - trabalho escravo e outras formas de trabalho indigno. 4.ed. São Paulo: LTR, 2018. 
BRITO FILHO. José Cláudio Monteiro de.. Trabalho escravo: caracterização jurídica. 2 ed. São Paulo: LTr Editora, 2017.

BUSINESS \& HUMAN RIGHTS RESOURCE. Establishing a Modern Slavery Act in Australia. Disponível em: https://www.business-humanrights.org/en/inquiry-intoestablishment-of-a-modern-slavery-act-in-australia. Acesso em: 10 de maio de 2018.

CANOTILHO, José Joaquim Gomes. Direito Constitucional e Teoria da Constituição. 4 ed. Coimbra: Almedina, 2000

FERRAZ JÚNIOR, Tércio Sampaio. A Ciência do Direito. 3 ed. São Paulo: Atlas, 2014. Função Social da Dogmática Jurídica. 2 ed. São Paulo: Atlas, 2015.

GÓMEZ, Rina Cáceres. El trabajo esclavo em Costa Rica. Revista de História, [S.I.], n. 39, july 2001. ISSN 2215-4744. Disponível em:

$<$ http://www.revistas.una.ac.cr/index.php/historia/article/view/2023> . Acesso em: 28 de julho de 2017.

GRECO, Rogério. Curso de direito penal: parte especial, vol. II: introdução à teoria geral da parte especial: crimes contra a pessoa. $7^{\mathrm{a}}$ ed. Niterói: Ímpetos, 2010.

LARENZ, Karl. Metodologia da Ciência do Direito. Tradução de José Lamego. 7 ed. Avenida de Berna/Lisboa: Fundação Calouste Gulbenkian, 2014.

MANNRICH, Nelson. Trabalho escravo: construindo um conceito. In: Impacto das normas internacionais da OIT no direito do trabalho e da sefuridade social: homenagem ao Prof. Dr. Cássio de Mesquita Barros Júnior. MONSALVE CUÉLLAR, Martha Elisa; SILVA, Luciana Aboim Machado Gonçalves da e PIERDONÁ, Zélia Luíza (coord). São Paulo: LTr, 2018.

MEIRELES, Edilton. Princípio do não-retrocesso social no direito do trabalho. Evocati Revista. N. 13. Jan. 2007. Disponível em: 
$<\mathrm{http}: / /$ www.evocati.com.br/evocati/artigos.wsp?tpm_cosartigo=100>. Acesso em: $15 / 05 / 2018$.

\section{ORGANIZAÇÃO DAS NAÇÕES UNIDAS. ONU. Declaração Universal dos Direitos}

Humanos. Resolução no 217 A (III) da Assembleia Geral das Nações Unidas. Dez. 1948. Disponível em: <http://www.direitoshumanos.usp.br/index.php/Declaração-Universal-dosDireitos-Humanos/declaracao-universal-dos-direitos-humanos.html $>$. Acesso em, 30 de maio de 2016.

\section{ORGANIZAÇÃO INTERNACIONAL DO TRABALHO. OIT. Combatendo o trabalho} escravo contemporâneo: o exemplo do Brasil. International Labour Office/ILO Office in Brasil. Brasília: ILO, 2010. (Livro digital).

ORGANIZAÇÃO INTERNACIONAL DO TRABALHO. OIT. Convenção 29 - Convenção concernente à trabalho forçado ou obrigatório, adotada pela Conferência em sua Décima Quarta Sessão - Genebra, 28 de junho de 1930 (com as modificações da Convenção de Revisão dos artigos finais, de 1946). Disponível em: $<$ http:// http://www.planalto.gov.br/ccivil_03/decreto/antigos/d41721.htm>. Acesso em 20 de abril de 2017.

ORGANIZAÇÃO INTERNACIONAL DO TRABALHO. OIT. Convenção 105 - Convenção concernente à abolição do trabalho forçado, promulgado pelo Decreto $n^{0} 58.822$, de 14 de julho de 1966. Disponível em: <http://www.planalto.gov.br/ccivil_03/decreto/19501969/D58822.htm>. Acesso em 20 de abril de 2017.

PARLIAMENT OF AUSTRALIAN. Terms of Reference. Disponível em: https://www.aph.gov.au/Parliamentary_Business/Committees/Joint/Foreign_Affairs _Defence_and_Trade/ModernSlavery/Terms_of_Reference. Acesso em 10 de maio de 2018.

RAMOS, André de Carvalho. Curso de Direitos Humanos. 3. ed. rev., atual. e ampl. - São Paulo: Saraiva, 2016. 
ROGRÍGUEZ, Vanesa. Prohibición de esclavitud y servidumbre. In: Convención Americana de Derechos Humanos y su proyeción en el Derecho Argentino. 1 ed. Buenos Aires: La Ley/Departamento de Publicaciones de la Facultad de Derecho, 2013.

SUPREMO TRIBUNAL FEDERAL. STF. Disponível em: www.stf.jus.br. Acesso em: 15 de maio de 2018. 


\title{
TRABALHO DECENTE E O FUTURO DO TRABALHO
}

\author{
José Claudio Monteiro de Brito Filho \\ Centro Universitário do Estado do Pará - CESUPA
}

\begin{abstract}
Resumo
Estudo que discute o trabalho decente e sua implementação, ao mesmo tempo em que analisa o futuro do trabalho, a propósito do centenário da Organização Internacional do Trabalho, a ser comemorado em 2019. O problema de pesquisa consiste em responder como compatibilizar a necessidade de lidar com a maneira como o trabalho é prestado, a partir da introdução de novas tecnologias e das mudanças ocorridas na sociedade, com o mínimo que deve ser garantido a todos os trabalhadores. É uma análise teórico-normativa, principalmente, mas que não se furta de utilizar dados para ilustrar aspectos da discussão, quando necessário.
\end{abstract}

Palavras-chave: Trabalho decente, Futuro do trabalho, Revolução tecnológica, Mudanças, Compatibilização.

\section{Abstract/Resumen/Résumé}

A study that discusses decent labor and its implementation, while analyzing the future of labor, in connection with the centennial of the International Labor Organization, to be celebrated in 2019. The research problem consists of responding how to reconcile the need of dealing with the way work is done, from the introduction of new technologies and changes in society, with the minimum that must be guaranteed to all workers. It is a theoretical-normative analysis, mainly, but it does not avoid using data to illustrate aspects of the discussion, when necessary.

Keywords/Palabras-claves/Mots-clés: Decente labor, Future of labor, Technological revolution, Changes, Compatibility.

\section{Introdução}

Atualmente, por conta da introdução de novas tecnologias, especialmente o uso maciço da rede mundial de computadores, mais conhecida como internet, bem como de alterações que 
continuamente ocorrem nos processos produtivos e na própria sociedade, é importante que sejam discutidas mudanças no plano normativo que acompanhem essas alterações fáticas, atualizando a relação jurídica que se desenvolve, nas sociedades que adotam a propriedade privada dos meios de produção, entre o trabalhador e o tomador dos seus serviços, mas, sempre sem esquecer que essa relação é assimétrica e que ainda se deve desenvolver sob o signo do princípio protetor, ou, como denomina Delgado (2018, p. 231), "da proteção", ou seja, considerando que o trabalhador é, na regulamentação, o sujeito protegido.

Além do mais, não pode ocorrer de maneira divorciada do fato de que há direitos básicos do trabalhador que são próprios de sua condição de pessoa, que devem ser respeitados em qualquer circunstância, e que configuram, como veremos melhor adiante, o que a Organização Internacional do Trabalho (OIT) convencionou chamar de trabalho decente, pois, há um mínimo que deve ser, sempre, respeitado.

Compatibilizar essas duas questões: mudanças - direitos indispensáveis, então, é imperioso em qualquer análise que se faça a respeito do trabalho humano e de seu futuro, e que é o que está, atualmente, ocorrendo no âmbito da OIT, por conta das comemorações do centenário de existência da Organização, que ocorrerá em 2019.

O problema de pesquisa consiste, dessa forma, em responder como deve ser compatibilizada a necessidade de lidar com a maneira como o trabalho é prestado, a partir da introdução de novas tecnologias e das mudanças ocorridas na sociedade, com o mínimo que deve ser garantido a todos os trabalhadores, constituindo essa análise, então, o objetivo central do estudo.

Metodologicamente, o estudo será uma análise teórico-normativa, principalmente, mas que não se furtará de se utilizar de dados para ilustrar aspectos da discussão, quando isso se fizer necessário.

A principal, embora não única, referência teórica é o livro Trabalho decente (BRITO FILHO, 2018b), por ser estudo que discute, desde sua primeira publicação, em 2004, o conjunto mínimo de direitos dos trabalhadores, tanto no plano normativo como no plano fático, e que vem, nas reedições, acompanhando a evolução do trabalho humano, tanto no plano internacional como no plano interno.

Como documentos que serão utilizados, o destaque vai para os que têm sido produzidos no âmbito da OIT, e que são preparatórios das comemorações de seu centenário, como já dito, especialmente um Informe relativo a essa efeméride, e que compõe as memórias do Diretor-Geral da Organização (2015), além do que sistematiza as discussões ocorridas com esse propósito, no Brasil (2018). 
Para dar conta do problema de pesquisa, o estudo, passada esta introdução, fará as considerações necessárias para a compreensão da ideia de trabalho decente, do que o fundamenta, e do que o compõe, e, em seguida, tentará discutir a questão do futuro do trabalho a partir das mudanças que vêm ocorrendo, como dito logo ao início, mas de forma compatível com o respeito aos direitos básicos, indispensáveis dos trabalhadores para, ao final, apresentar resposta ao problema de pesquisa.

\section{O trabalho decente}

Para a compreensão do que vamos discutir, não há dúvidas de que a primeira questão a elucidar diz respeito ao próprio significado de Trabalho Decente. É que essa expressão tem um significado preciso e, compreendê-la dá sentido para a análise que será feita.

Essa expressão foi utilizada pela Organização Internacional do Trabalho na Declaração sobre os Princípios e Direitos Fundamentais no Trabalho e seu seguimento, adotada na $86^{\text {a }}$ sessão da Conferência Internacional do Trabalho, em junho de 1998, sendo objetivo desta Declaração oferecer "um novo meio de promoção de tais direitos e princípios, muito especialmente para os estados que não ratificaram estas convenções” (OIT, 2000, p. 2).

As convenções referidas são, como veremos adiante, as que, exatamente, na visão da OIT, fixam os direitos fundamentais em matéria de trabalho, e a proposta é indicar, a partir delas, as condições para que, em qualquer lugar em que haja trabalho humano subordinado, possam ser respeitados os direitos fundamentais, indispensáveis, do trabalhador.

Assim, o conteúdo da Declaração confunde-se, ainda de acordo com o entendimento da OIT, com o "mínimo social que todos os estados devem respeitar no processo de mundialização no âmbito do mandato da OIT" (OIT, 2000, p. 5).

Tudo isso fica claro pela leitura do item 2 da Declaração, que preceitua:

2. Declara que todos os Membros, ainda que não tenham ratificado as convenções aludidas, têm um compromisso derivado do fato de pertencer à Organização de respeitar, promover e tornar realidade, de boa fé e de conformidade com a Constituição, os princípios relativos aos direitos fundamentais que são objeto dessas convenções, isto é:

a) a liberdade sindical e o reconhecimento efetivo do direito de negociação coletiva;

b) a eliminação de todas as formas de trabalho forçado ou obrigatório;

c) a abolição efetiva do trabalho infantil; e

d) a eliminação da discriminação em matéria de emprego e ocupação (OIT, 1998).

Em termos normativos, então, podemos afirmar que o trabalho decente compõe-se de quatro temas: 1) a liberdade sindical; 2) a liberdade no trabalho, representada pelo que a OIT 
denomina de trabalho forçado; 3) a igualdade no trabalho, e que consiste em criar condições para evitar e reprimir a discriminação; e 4) a proibição do trabalho infantil que, utilizando terminologia mais adequada para o Brasil, significa a proibição do trabalho da criança e a regularização, quando admitido, do trabalho do adolescente, e que se materializam em convenções, em número de oito (8), como será visto mais adiante.

A Declaração, esclarecemos, não se limita a elencar esses temas, materializados em textos normativos da Organização, e que indicam o que compõe o trabalho decente.

Ela pretende também fixar as ações que devem ser desenvolvidas pela OIT para auxiliar os membros da Organização a alcançar o trabalho decente, até porque é no âmbito dos Estados soberanos que o trabalho humano subordinado é prestado, servindo esse conjunto de um estímulo para que isso possa acontecer ${ }^{1}$.

Fixadas essas primeiras linhas básicas, o trabalho decente, em perspectiva que se pode chamar de institucional, deve ser compreendido como um conjunto de normas e ações que garantem àqueles que vivem do trabalho encontrar meios que garantam a sua subsistência e dos que lhes são dependentes, prestando o trabalho de forma que preserve a sua dignidade.

Já na perspectiva pessoal deve ser um trabalho digno, ou seja, livre, igual, e em que direitos mínimos sejam garantidos.

Notemos que essas perspectivas não são contraditórias; ao contrário, são somente a forma como se vê o trabalho decente sob a ótica de quem deve criar as condições para que ele seja realizado, com destaque, óbvio, para o Estado, e de quem vive, ou pretende viver essa situação: o trabalhador.

A propósito, cabe dizer que, na atualidade, garantir o trabalho decente é o objetivo principal da OIT, o mais relevante, no processo de modernização e renovação que empreende. Isso fica claro nas Memórias do Diretor Geral da Organização relativamente à $89^{\mathrm{a}}$ Reunião da Conferência Internacional do Trabalho (2001) quando, listando os objetivos de seu Programa, indica, ao início, a proposta de: "Centrar las energias de la OIT en el trabajo decente como una de las principales demandas globales de nuestra época" (OIT, 2001, p. 1).

Fica claro, a partir disso, que trabalho decente é o mínimo indispensável para a vida digna das pessoas, no aspecto do trabalho, ou seja, compõe, na esfera trabalhista, o que se convencionou denominar, no plano internacional, de Direitos Humanos - e, no plano interno, de Direitos Fundamentais - para os trabalhadores.

\footnotetext{
${ }^{1}$ Esse o objetivo do seguimento da Declaração, que está em anexo a esta, como se verifica do subitem I.1 deste anexo.
} 
Isso, é bom que esclareçamos, sem esquecer que os trabalhadores são possuidores de todos os outros Direito Humanos, muitos deles com relação íntima com a condição que detém: de viverem de sua força de trabalho, como a educação, a saúde, o direito à informação etc. Apenas não compõem estes o trabalho decente, que são somente os direitos que têm relação direta com o trabalhador e com a condição que desta particularidade resulta.

E o que são os Direitos Humanos? Os direitos mínimos indispensáveis para que a pessoa humana tenha respeitada a sua dignidade.

Embora não exista, em texto que deve ser breve, espaço para explicarmos com detalhes a relação direta entre a dignidade da pessoa humana e os Direitos Humanos, devemos, pelo menos, dizer que essa noção é feita a partir da concepção kantiana de dignidade, e que pode ser vista, na obra de Immanuel Kant denominada Fundamentação da metafísica dos costumes (2003).

Devemos, também, dizer que essa relação, na perspectiva kantiana, é estabelecida a partir da ideia de que, para esse autor, a dignidade é o principal atributo do ser humano, e este atributo, além de não poder ser perdido, não poderá, também, ser violado. O que Kant quer é impedir a instrumentalização do ser racional, o tratamento deste ser como meio — ver, na obra já indicada, o imperativo categórico em sua formulação prática - e os Direitos Humanos, entendidos como os direitos indispensáveis de todos os seres humanos, prestam-se a essa proteção. Por isso que a dignidade é considerada o fundamento dos Direitos Humanos ${ }^{2}$

Disso decorre que os Direitos Humanos são os direitos mais importantes do ser humano, no sentido de que constituem o núcleo mínimo que garante o respeito à sua condição de pessoa, não podendo, em nenhuma circunstância, ser negados.

Como são os mais importantes, é no mínimo lógico que devam receber proteção prioritária, assim como um olhar diferenciado, comparativamente com outros direitos, que podem ser relevantes e justos, mas, ainda assim, secundários em comparação com os que são, como dito, os mais importantes.

Notemos a propósito que os Direitos Humanos - e, no plano interno, os Direitos Fundamentais - , estão em plena compatibilidade com a noção contemporânea de democracia, que é a democracia constitucional, que preserva a ideia central de que as decisões são tomadas pela chamada regra da maioria - desde que essa maioria seja formada a partir de um processo de igualdade política, ou seja, e discorrendo sinteticamente, em que todos com capacidade eleitoral podem livremente votar, formando-se a maioria dessa deliberação coletiva e igual —,

\footnotetext{
${ }^{2}$ Ver, a respeito, por exemplo, Brito Filho (2018a, p. 43-50)
} 
mas, sempre respeitados os acordos definidos como básicos pela sociedade, onde se encontram os direitos indispensáveis dos indivíduos, vistos em uma tríplice dimensão: individual, coletiva e difusa.

Por outro lado, embora reconheçamos o protagonismo da OIT na questão, especialmente pela oportunidade de discutir os Direitos Humanos dos trabalhadores, chamando atenção para a necessidade de seu reconhecimento e de sua implementação, até com a proposta de criação de mecanismos da própria Organização para que isso ocorra, pensamos que o rol de direitos listados na Declaração acima indicada é insuficiente para definir, em relação aos trabalhadores, o mínimo a proteger, sendo conveniente a utilização de outros instrumentos internacionais em matéria de Direitos Humanos no trabalho.

Nesse sentido, é imperioso o uso da Declaração Universal dos Direitos Humanos (DUDH), da Organização das Nações Unidas (ONU), de 1948, e que, embora seja um pacto de natureza política, não deve ser vista como totalmente destituída de força normativa ${ }^{3}$.

Tão importante quanto é a utilização do Pacto Internacional sobre os Direitos Econômicos, Sociais e Culturais (PIDESC), também da ONU, agora de 1966, tendo sido este instrumento normativo internacional ratificado pelo Brasil em $1992^{4}$.

É que o PIDESC possui um rol de direitos dos trabalhadores, nos planos individual e coletivo, mais amplo que o da OIT que, por trabalhar somente com liberdade no trabalho, igualdade no trabalho, liberdade sindical e proibição do trabalho da criança e regularização do trabalho do adolescente, direitos importantes, mas incompletos como conjunto, deixa de lado questões que são básicas, que compõem os Direitos Humanos dos trabalhadores, e que não podem ser esquecidas, como a justa remuneração pelo trabalho, as justas condições de trabalho, o meio ambiente de trabalho equilibrado e a proteção contra os riscos sociais, entre outros.

A ampliação do rol de direitos que compõem o Trabalho Decente, então, obedece à lógica de oferecer proteção para os direitos indispensáveis dos trabalhadores, mas ainda a partir de uma base normativa que se compõe, recuperando a ideia, da Declaração da OIT e instrumentos que concentram os direitos por ela referidos: Convenções 29 e 105 (liberdade no trabalho / proibição do trabalho forçado), 100 e 111 (igualdade no trabalho / proibição da discriminação), 87 e 98 (liberdade sindical), e 138 e 182 (proibição do trabalho da criança e regularização do trabalho do adolescente), mas também da Declaração Universal dos Direitos

\footnotetext{
${ }^{3}$ No sentido de ter a DUDH efeitos normativos, por ele denominados de "força vinculante", entende Comparato (1999, p. 209-210).

${ }^{4}$ O Decreto n. 591, de 6 de julho de 1992, do Presidente da República, apresenta, em seu anexo, a versão em português do PIDESC.
} 
Humanos (artigos XXIII e XXIV), e do Pacto Internacional dos Direitos Econômicos, Sociais e Culturais (artigos $6^{\circ}$ a $9^{\circ}$ ).

Com isso, o Trabalho Decente passa a ser composto dos seguintes direitos, divididos em três planos: individual, coletivo e da seguridade.

No plano individual: direito ao trabalho; liberdade de escolha do trabalho; igualdade de oportunidades para e no exercício do trabalho; direito de exercer o trabalho em condições que preservem a saúde do trabalhador; direito a uma justa remuneração; direito a justas condições de trabalho; principalmente limitação da jornada de trabalho e existência de períodos de repouso; proibição do trabalho da criança e regularização do trabalho do adolescente.

Notemos que este plano concentra, naturalmente, variada gama de direitos, como forma de proteger os trabalhadores em relação que se caracteriza pela subordinação destes ao tomador de serviços.

No plano coletivo: liberdade sindical.

Aqui, embora a enunciação seja sintética, a proteção é ampla, envolvendo as duas dimensões da liberdade sindical: a individual e a coletiva, e, dentro destas, todos os seus aspectos. Da dimensão coletiva, as liberdades de associação, de organização, de administração, e de exercício das funções, e, da dimensão individual, as liberdades de filiação, desfiliação e não filiação ${ }^{5}$.

No plano da seguridade: proteção contra o desemprego e outros riscos sociais.

Aqui, cabe relembrarmos que risco social deve ser entendido como todo evento que impeça ou dificulte a subsistência das pessoas e das que lhe são dependentes, como o desemprego, expressamente citado, mas também como o acidente, a doença, a morte, entre outros (BRITO FILHO, 2018b, p. 51-57).

Esse conjunto é que defendemos que componha o trabalho decente, sendo um conjunto de direitos que devem ser garantidos a todos os trabalhadores, em qualquer circunstância, por configurarem os direitos básicos, essenciais, de todos os que usam sua força de trabalho para garantir a sua subsistência e dos que lhes são dependentes.

Feito isso, ou seja, estabelecidas as bases mínimas para a compreensão da ideia de trabalho decente, tentaremos, no item a seguir, compatibilizá-la com as mudanças que vêm ocorrendo no mundo do trabalho.

\footnotetext{
${ }^{5}$ Para uma visão mais completa das dimensões da liberdade sindical ver, também, Brito Filho (2017, p. 89-107).
} 


\section{O futuro do trabalho e os direitos mínimos dos trabalhadores}

Atualmente, discute-se o futuro do trabalho humano, até em razão dos 100 anos da criação da OIT, que ocorrerá em 2019, tendo essa temática uma importância central nas comemorações. Essas discussões foram propostas pela própria OIT, como forma de dar uma direção à atuação da Organização de seu centenário em diante.

A ideia, como fala o Diretor-Geral do Conselho de Administração da Organização, é colocar "en marcha un proceso que permita orientar su labor en pro de la justicia social al iniciar su segundo siglo de existencia" (OIT, 2015, p. iii).

Para a Organização Internacional do Trabalho, as mudanças havidas no mundo do trabalho são de uma grandeza tal que têm produzido mudanças que precisam ser compreendidas e discutidas (OIT, 2015, p. 1).

Essas mudanças já estão ocorrendo há algum tempo, especialmente a partir do que pode ser denominado de revolução tecnológica, que gerou novas formas de produção, com afetação direta do mercado de trabalho, pela exigência de trabalhadores com novas expertises e pelas novas formas de como o trabalho é prestado.

E ela (a revolução tecnológica) suscitou uma série de questionamentos, trazendo à tona novas teorias, que passaram, por exemplo, pela ideia de flexibilização do Direito do Trabalho, até chegar à própria noção de desregulamentação no plano individual, ou, ao menos, a uma diminuição das normas ou à atenuação de seus efeitos.

Gerou também mudanças. Conforme informa Antunes (1997, p. 34-35), nos países capitalistas mais desenvolvidos houve decréscimo na quantidade de empregos a tempo completo, com o aumento da precarização do trabalho.

Mas, não foi somente a revolução tecnológica que exigiu mudanças. A própria modificação dos costumes, da forma com as pessoas vivem e/ou querem viver, bem como das práticas das empresas, motivadas por razões diversas, dentre elas as que decorrem do surgimento de novos mercados, locais ou não, exigiram isso.

Isso, de forma clara, ocorreu também no Brasil, com produção normativa a respeito, também. Recentemente, duas alterações legislativas em matéria trabalhista, por meio das Leis n. 13.429 e n. 13.467 , ambas de 2017 — a segunda chamada de "reforma trabalhista", e que produziu modificações de monta, principalmente na Consolidação das Leis do Trabalho (CLT) —, a pretexto de modernizar a legislação do trabalho, introduziram algumas modificações 
normativas que têm relação direta com a revolução tecnológica, como o teletrabalho e a flexibilização ampla do Direito do Trabalho, assim como a desconcentração da prestação de serviços.

Ainda que se possa dizer que as alterações tiveram viés claramente conservador, o que é verdade, e o que conduziu à precarização do trabalho, em razão de alguns institutos, como são os casos do trabalho intermitente e da terceirização ampla da prestação de serviços, especialmente pelas opções e pelos caminhos adotados pelo legislador ordinário, é também certo dizer que era necessário disciplinar situações que já estavam no mundo do trabalho, e que ainda não eram objeto da conveniente regulamentação, especialmente quando se está diante de uma relação assimétrica entre os contratantes.

O caso do teletrabalho é emblemático. Algumas atividades profissionais não precisam mais ser executadas na empresa, ou melhor, na unidade produtiva mantida pelo empregador, chamada de estabelecimento. Podem ser feitas de forma remota, sem qualquer prejuízo para a atividade.

E isso traz vantagens. Para o empregador, por exemplo, pois diminui seus custos e torna possível o desenvolvimento da atividade empresarial em um espaço menor, ainda que ele ainda mantenha a obrigação de arcar com os equipamentos necessários. Para o trabalhador, ainda como exemplo, por eliminar o tempo ocioso que é gasto no deslocamento nos trechos domicílio - local de trabalho - domicílio, além de gerar a possibilidade de este administrar melhor seu tempo, especialmente se estiver obrigado a prestar o trabalho a partir de sua produtividade, e não do tempo à disposição do empregador. Há problemas que daí podem surgir, bem como a possibilidade de ocorrerem abusos? Sim, mas, é uma questão de como regulamentar, e de como fiscalizar esse regramento, não de, por conta da possibilidade de abusos, ignorar que a melhor solução é permitir, regulando, o que já é um fato real.

No tocante à terceirização, embora se deva tê-la como excessiva, pela possibilidade agora normatizada de ocorrer até na atividade-fim do tomador dos serviços, é certo que seu disciplinamento em norma estatal já deveria ter ocorrido, superando o seu precário disciplinamento pela jurisprudência uniforme do Tribunal Superior do Trabalho que, por poder ser continuamente modificada, gerava o risco de insegurança, podendo tornar-se um fardo difícil de carregar, tanto pelos trabalhadores, como pelos empregadores.

Quanto ao trabalho intermitente, não obstante o modo como foi disciplinado tenha sido bem ruim para os trabalhadores, de há muito que reclamava regulamentação, pois sempre ocorreu, especialmente em alguns segmentos da atividade econômica, como no de turismo e hospitalidade, de forma ainda mais precária do que agora, e com resultados, nas demandas 
judiciais, imprevisíveis. É claro que não se vai poder utilizar o trabalho intermitente em qualquer caso, como já se vislumbra, mas, isso a jurisprudência da Justiça do Trabalho estancará.

Por fim, para ficarmos em poucos exemplos das reformas na legislação do trabalho, tem-se a flexibilização ampla do Direito do Trabalho, prevista no artigo 611-A, da CLT que, não obstante possa ser nefasta na hipótese de se ter um modelo ultrapassado de organização sindical, como é o caso do Brasil, é claramente uma forma adequada de resolver conflitos, tanto em casos de crise, como de problemas localizados em um dado segmento econômico.

A necessidade de discutir as mudanças havidas no mundo do trabalho e/ou que nele interferem, dessa feita, é real, e a OIT andou bem em eleger essa nova prioridade. O problema é entender que isso possa ocorrer de forma livre, sem condicionantes, como se a imperiosidade de mudanças abrisse margem para todas as alterações que forem possíveis, sem condicionantes.

Em boa medida, voltando à reforma trabalhista brasileira, é o que se vê.

Permitiu-se a flexibilização ampla do Direito do Trabalho via contratação coletiva, sem qualquer preocupação com a reforma de nosso modelo sindical, que não sustenta entidades sindicais fortes e representativas, e é incompatível com a Convenção n. 87 da OIT, que trata da liberdade sindical e compõe o elenco mínimo do trabalho decente, com o risco de, a partir do que é uma boa ideia, precarizar-se ainda mais o trabalho humano subordinado.

A esse respeito, documento produzido pela OIT a propósito das discussões no Brasil a respeito do futuro do trabalho $(2018$, p. 72$)$, trata de problemas no modelo de organização sindical, e que impactariam negativamente na negociação coletiva. Diz o documento:

\begin{abstract}
Nota-se que a estrutura sindical vigente no Brasil também necessita de ajustamentos, tais como o fim da unicidade sindical, o cadastramento obrigatório junto ao Ministério do Trabalho e Emprego para o seu funcionamento, o recolhimento compulsório do imposto sindical, os mandatos contínuos que perpetuam a direção de sindicatos no poder, e a não publicização da prestação de contas são tópicos a serem discutidos. $\mathrm{O}$ total de sindicatos de categorias econômicas e categorias profissionais beira quase $\mathrm{o}$ número de 12 mil, muitos dos quais foram criados para obtenção do imposto sindical e têm participação pouco ativa nas relações de trabalho.
\end{abstract}

Em igual direção, as novas normas a respeito do trabalho das gestantes e das lactantes, assim como da jornada de trabalho, em caráter geral, atraem problemas para a existência de um meio ambiente do trabalho equilibrado, quando o caminho, em princípio, deveria ser o inverso, pois nossa regulamentação a respeito está superada e é claramente patrimonialista.

Assim, embora nos pareça claro que é preciso repensar o trabalho humano por conta das mudanças ocorridas, parece-nos óbvio também que, isso deve ocorrer com o respeito ao 
reconhecimento de que o princípio protetor ainda é um parâmetro que não se deve afastar, pois a assimetria na relação entre tomador e trabalhador, não desapareceu, ainda sendo necessária a proteção do segundo.

De igual modo, não é possível acreditar que as mudanças podem ignorar os direitos básicos dos trabalhadores, o trabalho decente, pois, esses direitos são devidos a qualquer trabalhador, em qualquer lugar do planeta, e em qualquer circunstância.

No caso das discussões a respeito do futuro do trabalho que estão sendo feitas no Brasil, não nos parece que isso esteja sendo, de forma clara, considerado.

Foram realizados quatro (4) diálogos coordenados pela OIT e pelo Ministério do Trabalho em Emprego (MTE). O primeiro em 18 de maio de 2016, em Brasília - DF, e denominado "Primeiro Diálogo Nacional sobre o Futuro do Trabalho"; já o segundo, denominado "Trabalho e Sociedade", e o terceiro, denominado "Trabalho Decente para Todos e para Todas", ocorreram em São Paulo - SP, no dia 21 de novembro de 2016; e, por fim, o quarto, denominado “Quarto Diálogo Nacional sobre o Futuro do Trabalho”, realizou-se no Rio de Janeiro - RJ, no dia 18 de maio de 2017.

Essas discussões foram, depois, sintetizadas em único documento, publicado pela OIT (2018), já mencionado acima, e denominado Futuro do Trabalho no Brasil: Perspectivas e Diálogos Tripartites.

Por esse documento, verificamos um reconhecimento adequado dos desafios, uma análise com viés econômico muito forte, e uma preocupação com os empregos como pontos de destaque, além de algumas discussões pontuais a respeito de questões como terceirização e flexibilização.

Não nos parece, por outro lado, que tenha havido grandes debates a respeito de manter o Direito do Trabalho sob o signo do princípio protetor, com suas normas refletindo de forma nítida esse princípio, nem com o trabalho decente, ou seja, com o fato de que qualquer discussão a respeito do trabalho humano subordinado deve considerar direitos básicos, indispensáveis, para todos os trabalhadores.

Até o Terceiro Diálogo, que deveria ser centrado no trabalho decente, está sintetizado no documento já mencionado em discussões a respeito de urbanização.

Nesses termos, não nos parece que as discussões tenham abrangido todos os aspectos necessários, pois, o desafio, claro, é conciliar um mundo do trabalho que precisa se ajustar às novas tecnologias e às novas dinâmicas da vida em sociedade, com, conforme dados fornecidos pela própria OIT: 
I - um mundo com 200 milhões de desempregados, e que, portanto, sofrem com o risco social do desemprego, não tendo a proteção adequada, o que se agrava com a estimativa de que é preciso criar, até 2030, 600 milhões de empregos somente para voltar ao nível que se tinha antes da crise de 2008;

II - a situação de morte de 2,3 milhões de pessoas por ano em razão do trabalho e, por isso, submetidas a um ambiente do trabalho que está longe de ser equilibrado e que é propenso a acidentes;

III - o fato de que há 21 milhões de pessoas em situação de trabalho forçado, comprometendo a direito básico à liberdade no trabalho;

IV - a situação de calamidade de termos 168 milhões de crianças trabalhando (OIT, 2015, p. 5, 10 e 11), com prejuízos óbvios para seu desenvolvimento como pessoas, entre outros problemas.

E, como também é afirmado pela OIT, por seu Diretor-Geral, sem deixar de considerar que resistir às inovações é, muito mais que errôneo ou contraproducente, una guerra perdida; [pois] no hay ninguna manera creíble de ofrecer resistência (2015, p. 13), e até porque os avanços tecnológicos não são, em si, nocivos. O que pode gerar prejuízos para os trabalhadores é a maneira como se vai lidar com isso na hora de regular o trabalho humano, principalmente o subordinado.

Não há uma resposta fácil para isso, pois, ainda que se reconheça que é preciso que o trabalho esteja inserido em um mundo em transformação, não podendo ser pensada a relação entre empregado e empregador da mesma forma que era pensada na época das duas primeiras revoluções industriais, é mais certo, ainda, que as condições mínimas para que o trabalhador não seja instrumentalizado, com sua dignidade respeitada, devem ser buscadas sem tréguas.

A solução, então, parece, é respeitar esse padrão mínimo, não negociável, e, daí em diante, buscar os consensos possíveis para adequar a legislação que rege o trabalho subordinado às mudanças.

\section{Conclusão}

É inegável que o mundo do trabalho tem passado por transformações de monta. A introdução de novas tecnologias, como, por exemplo, o uso da internet como ferramenta de trabalho, tem modificado a forma como o trabalho é prestado, ou, até, como ele pode ser prestado. De igual maneira, as mudanças nos costumes, na forma como as pessoas vivem 
também impactam na regulação do trabalho, que é um componente importante na vida das pessoas, mas, não é, seguramente, o único.

Não há sentido, então, em nos aferrarmos a ideias que, antes, pareciam básicas e naturais, como, apenas como exemplo, a fixação rígida do local de trabalho, quando, em relação a algumas atividades profissionais é possível desenvolvê-las sem uma base fixa, e, que, a cargo do empregador, pode representar custos que podem ser minorados, com as possíveis e previsíveis - mas quase sempre irreais, lamentavelmente —, redução desses custos no preço final dos serviços prestados e/ou produtos colocados à disposição, e elevação do valor dos salários.

Da mesma forma, não ter como local de trabalho o estabelecimento, entendido como o local onde o empregador desenvolve suas atividades, no caso do trabalhador pode significar, entre outras vantagens, não ter de dispender significativa parte de seu tempo no deslocamento de seu domicílio para o local de trabalho, e vice-versa, além de permitir ao trabalhador organizar diretamente o seu tempo de trabalho, sem interferências maiores do tomador dos serviços.

$\mathrm{Na}$ mesma direção, é fato que a forma como a sociedade se organiza deve refletir na organização do trabalho, e ignorar esse fato significa manter rígido um ambiente, no caso o do trabalho, enquanto todos os outros passam a ser regidos por uma maior dose de flexibilidade.

É de todo conveniente, então, refletirmos em mudanças, até no plano normativo, que compatibilizem a norma trabalhista com todo esse repertório de mudanças havidas no mundo da vida e nos processos produtivos.

Oportuno, dessa feita, o chamamento da OIT para que, a propósito do centenário dessa Organização, discutamos, em todo o mundo, o futuro do trabalho e, tanto quanto, que discutamos o futuro do trabalho considerando as mudanças acima resumidas.

Isso, todavia, não muda o fato de que a relação que se estabelece entre trabalhador e empregador, salvo mínimas exceções, continua assimétrica, com o primeiro subordinado juridicamente ao segundo, que controla os meios de produção e dirige a prestação pessoal dos serviços.

Qualquer mudança na regulamentação do trabalho, então, deve ter em mente o princípio protetor, que é o princípio maior do Direito do Trabalho, e reconhece que esse subsistema jurídico deve ser construído e aplicado considerando a condição de hipossuficiente do trabalhador.

Em igual direção, devemos ter em mente que qualquer alteração deve respeitar o núcleo básico, essencial, dos direitos dos trabalhadores, o que a OIT convencionou chamar de 
trabalho decente, sob pena de abrirmos espaço para a instrumentalização do ser humano, com clara ofensa à dignidade da pessoa humana.

Isso lembrando que não é o caso nem de, simplesmente, dizer que o que se deve é preservar o que já foi conquistado, pois, caso queiramos falar de conquistas, elas aconteceram, até agora, somente no plano normativo, nos Estados em que isso aconteceu, pois, no plano fático, estamos longe, ainda, de ter algo sequer similar ao trabalho decente para todos os trabalhadores.

Esse deve ser o futuro do trabalho: um mundo em que todos tenham trabalho decente.

Nesses termos, é importante discutir os impactos das novas tecnologias e da mudança dos costumes no mundo do trabalho, mas, antes de tudo, isso deve ser pensado em ambiente em que o mínimo seja respeitado, com os principais esforços sendo direcionados a garantir o que ainda, na realidade, não existe: direitos mínimos para os que vivem de seu trabalho.

\section{Referências bibliográficas}

ANTUNES, Ricardo. Mundo do trabalho, precarização e desemprego. In MARQUES, Rosa Maria (Org.). Mercado de trabalho e estabilização. Cadernos PUC Economia 4. São Paulo: Educ, 1997.

BRITO FILHO, José Claudio Monteiro de. Direito sindical. 6 ed. São Paulo: LTr, 2017. . Direitos humanos. 2 ed. São Paulo: LTr, 2018a. Trabalho decente. 5 ed. São Paulo: LTr, 2018 b.

COMPARATO, Fábio Konder. A afirmação histórica dos direitos humanos. São Paulo: Saraiva, 1999.

DELGADO, Mauricio Godinho. Curso de direito do trabalho. 17 ed. Sâo Paulo: LTr, 2018.

KANT, Immanuel, Fundamentação da metafísica dos costumes. Tradução de Paulo Quintela. Lisboa - Portugal: Edições 70, 2003. 
OIT. Declaração sobre os princípios e direitos fundamentais no trabalho, de 9 de junho de 1998. Disponível em

http://www.ilo.org/public/english/standards/declaration/declaration_portuguese.pdf. Acesso em $1^{\circ}$ de maio de 2018.

. Declaração de Princípios da OIT: um novo instrumento para promover os direitos fundamentais. Guia de educação operária. 1 ed. Suíça: Repartição Internacional do Trabalho, 2000.

. Reducir el deficit de trabajo decente: un desafío global. Primera edición, Ginebra Suiza: Oficina Internacional del Trabajo, 2001.

. Memoria del Director General - Informe I: La iniciativa del centenario relativa al futuro del trabajo. Conferencia Internacional del Trabajo, 104. ${ }^{a}$ reunión, 20151 ed. Ginebra Suiza: Oficina Internacional del Trabajo, 2015.

Futuro do Trabalho no Brasil: Perspectivas e Diálogos Tripartites. 2018. Disponível em http://www.ilo.org/wcmsp5/groups/public/---americas/---ro-lima/---ilobrasilia/documents/publication/wcms_626908.pdf. Acesso em 3 de maio de 2018. 
E

ste livro reúne artigos científicos apresentados e debatidos nos Grupos de Trabalho: "EFETIVIDADE DOS DIREITOS HUMANOS, CULTURAS JURÍDICAS E MOVIMENTOS SOCIAIS" e "DIREITO DO TRABALHO E EFICÁCIA DOS DIREITOS FUNDAMENTAIS NO MEIO AMBIENTE DO TRABALHO" no decorrer do VIII Encontro Internacional do CONPEDI (Conselho Nacional de Pesquisa e Pós-Graduação em Direito - Brasil), realizado entre os dias 06 e 08 de setembro de 2018 na cidade de Zaragoza - Espanha. 